\title{
Comunicación del Conocimiento / Conocimiento de la Comunicación
}

\author{
AUTOR: Paula Inés Porta \\ DIRECTOR: Carlos Giordano
}





\section{Agradecimientos}

"Todo lo que sabemos, lo sabemos entre todos"1

Convencida de que esta tesis es parte de un largo proceso de enseñanzas, del que formaron parte tantos sujetos e instituciones a los que siempre les agradeceré por sus aportes concretos, por enriquecer y facilitarme el camino.

Gracias a mis viejos, Ana y Atilio. A cada uno de mis hermanos: Silvia, Andrés, Quique, Laura, Richie, Javier, a mi querido Juan Q, ellos son mi matriz de aprendizaje.

Gracias especialísimas a mi hermanita Laura, por su dedicación y talento reflejados en el diseño de la tesis.

Gracias a Carlos por su compromiso, dirección y acompañamiento.

Gracias a los compañeros que me ayudaron y ayudan siempre: Florencia, Nancy, Lili, Chino, Silvina, Verónica, Miguel, Mario, Bianca, Natalia, María Julia, Diego, Rocío, Luciana, Carla, Yanina, Romina, Claudia, Pablo, Virginia, Ana Paula, Juan Francisco.

Gracias por los aprendizajes y el amor cotidiano a Carlos, Juan y Fermín, para ellos: todo! 


\section{Índice}

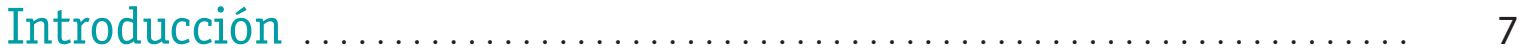

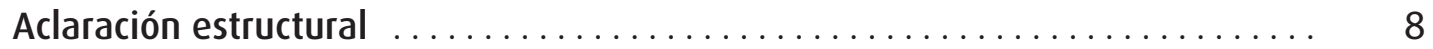

Afirmaciones metodológicas $\ldots \ldots \ldots \ldots \ldots \ldots \ldots \ldots \ldots \ldots \ldots \ldots \ldots$

Devenir denso. Descripciones ............................ 11

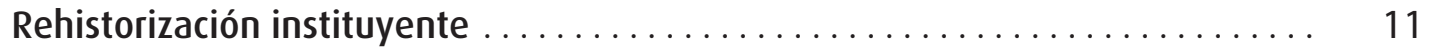

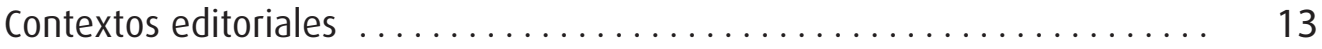

Aprender lo aprendido ............................... 13

Lo concreto del inicio ................................ 16

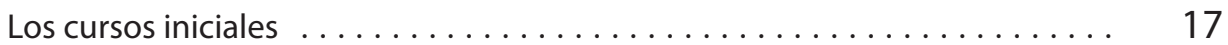

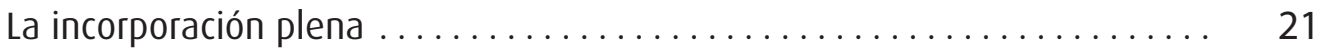

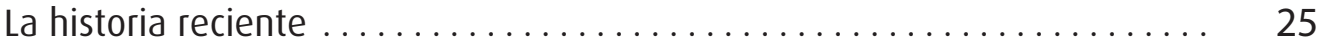

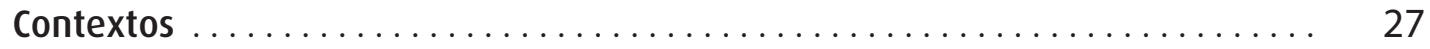

La Universidad Pública en los '90 ...................... 27

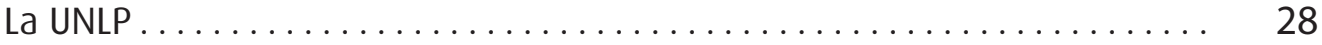

Los estudios en comunicación ........................... 30

Los escenarios del desafío ................................ 35

Mayor crecimiento .................................. 36

Una vez más, son nuevas aquellas preguntas $\ldots \ldots \ldots \ldots \ldots \ldots \ldots . \ldots . \ldots 38$

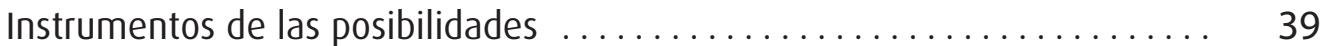

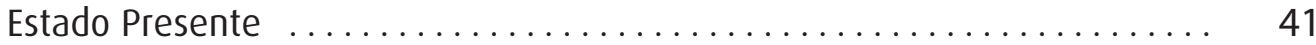

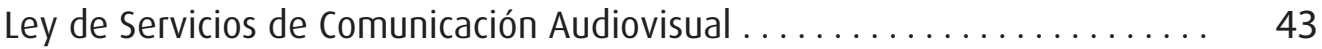

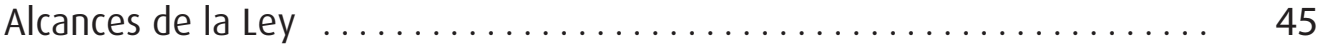

Proceso Reglamentación $\ldots . \ldots \ldots \ldots \ldots \ldots \ldots \ldots \ldots \ldots \ldots \ldots . \ldots \ldots$

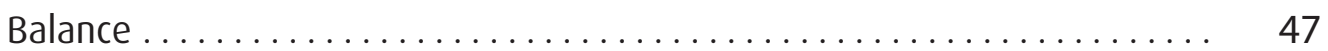

Políticas de Implementación .......................... 50

Consejo Asesor de la Comunicación Audiovisual y la infancia . . . . . . . . 50

Defensoría del Público de Servicios de Comunicación Audiovisual . . . . . . . 50

Radio y Televisión Argentina Sociedad del Estado . . . . . . . . . . . . . . . . 51

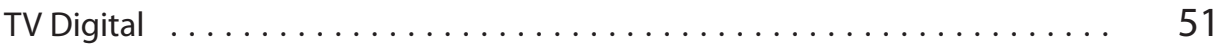

Contenidos .................................. 52

Multiplicar Palabras / Imágenes ............................. 54

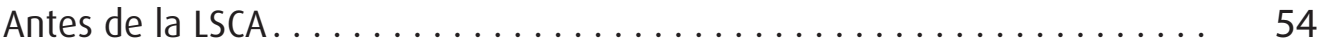

Canal Encuentro ................................ 54

Encuentro en la Web ................................ 55

PakaPaka .......................................... 56 


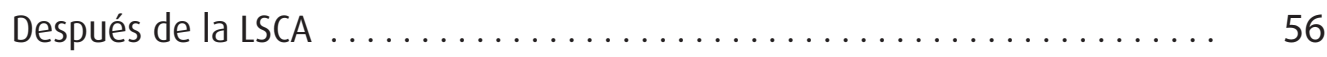

TaTeTi: un mundo de diversión sin igual. . . . . . . . . . . . . . . 57

DEPORTV ........................................ 57

INCAA TV ....................................... 58

TECtv. La señal de la Ciencia. . . . . . . . . . . . . . . . . . . 58

Universidad y medios de comunicación . . . . . . . . . . . . . . . . . . . . . 59

Las radios y los canales universitarios ....................... 59

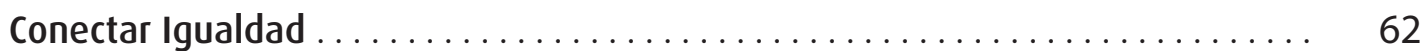

Descripción del Programa .................................... 64

Fundamentos ............................... 66

Estructura ............................... 67

Las Netbooks .................................. 68

Decisiones en Red . . . . . . . . . . . . . . . . . . . . . . . . . . . . . . . 69

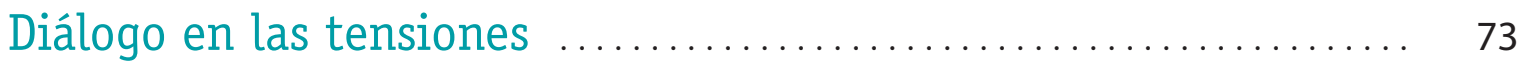

Los estudiantes ....................................... 73

Imaginario acerca de la Profesión y la Facultad ................. 76

Prácticas Comunicacionales Cotidianas $\ldots \ldots \ldots \ldots \ldots \ldots \ldots \ldots \ldots . \ldots \ldots$

Modos de Aprender $\ldots . \ldots \ldots \ldots \ldots \ldots \ldots \ldots \ldots \ldots \ldots . \ldots \ldots \ldots$

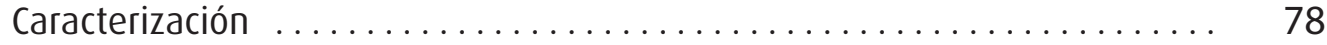

Datos Personales ............................ 78

¿Con quién viven? ............................. 79

Situación Laboral . . . . . . . . . . . . . . . . . . . . . . . . . . . . . . . $\quad 79$

Datos Educativos ......................................... 80

Área Educación. Profesorados ............................ 80

Área Técnica .................................... 80

Área Comunicación ................................. 81

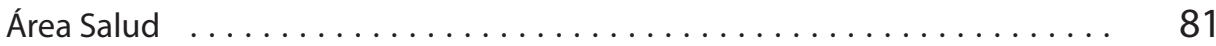

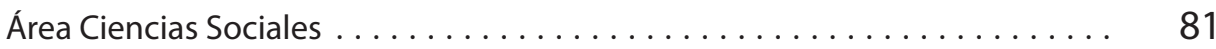

Del escenario imaginado: . . . . . . . . . . . . . . . . . . . . 81

Del análisis de la información de las encuestas hacemos la siguiente agrupación. $\quad 82$

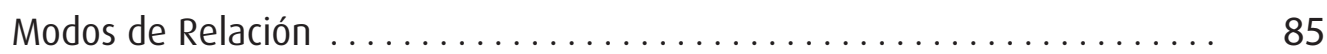

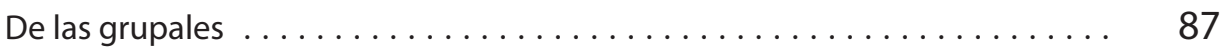

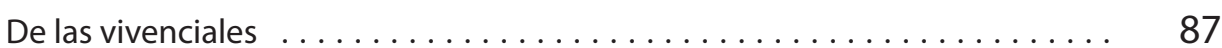

De las individuales ................................ 87

Caracterización sobre el aprendizaje $\ldots \ldots \ldots \ldots \ldots \ldots \ldots \ldots \ldots \ldots . \ldots . \ldots . \ldots$

¿Qué es aprender? ............................ 89

¿Cómo se aprende? .............................. 89

¿Cuáles son las condiciones para aprender? .................. 89 
Percepción sobre Educación $\ldots \ldots \ldots \ldots \ldots \ldots \ldots \ldots \ldots \ldots \ldots \ldots \ldots$

Sentido de la educación. . . . . . . . . . . . . . . . . . . . . . . . . . . 91

Prácticas Comunicacionales Cotidianas ......................... 91

Sobre consumos culturales.......................... 96

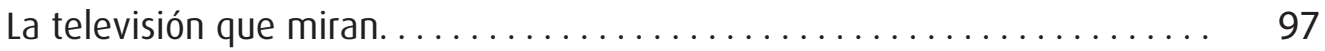

¿Cuántos televisores hay en tu casa? . . . . . . . . . . . . . . . . . 97

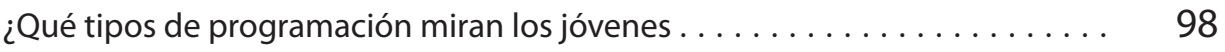

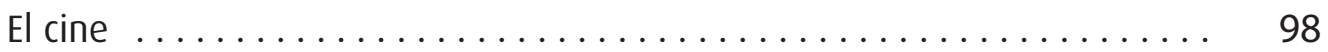

Los usos de internet en los estudiantes ....................... 99

Afirmaciones sobre el acontecimiento ......................... 103

Definiciones. Ejes sobre la calidad de los encuadres ............ 111

La comunicación como campo de estudio ....................... 116

Comunicación: campo propio abierto a interpelaciones ............... 116

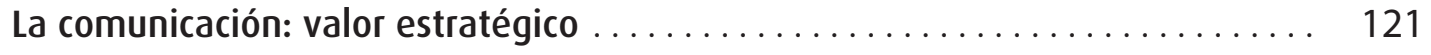

Breve paneo por las principales teorías .................... 123

Comunicación, Medios, Modernidades ........................ 128

Comunicación/Poder ............................................ 132

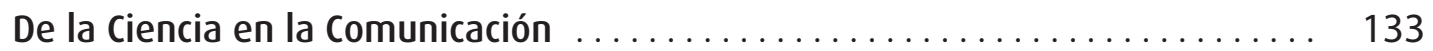

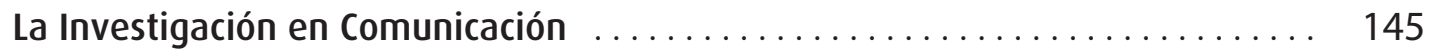

Es así como aparecen nuevos enfoques, objetos y problemas . . . . . . . 147

De la Convergencia tecnológica a los saberes compartidos . . . . . . . . . . . . 151

Comunicación y Convergencia . . . . . . . . . . . . . . . . . . . 153

Cultura Participativa. .................................. 159

Estas nuevas habilidades incluyen: . . . . . . . . . . . . . . . 159

Inteligencia Colectiva ........................... 160

Prácticas y saberes operantes ............................. 163

Entonces, lo curricular............................... 163

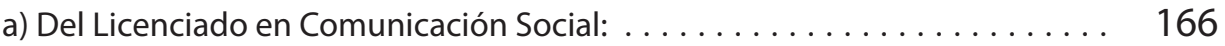

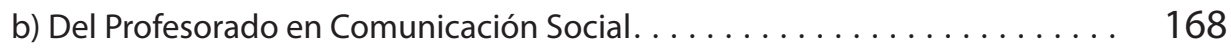

Sobre la flexibilidad y autoestructuración curricular . . . . . . . . . . . . . 169

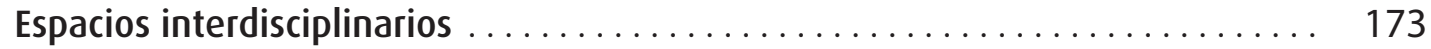

Producción de conocimientos e investigación en el grado . . . . . . . . . . . . 174

Consideraciones finales................................. 179

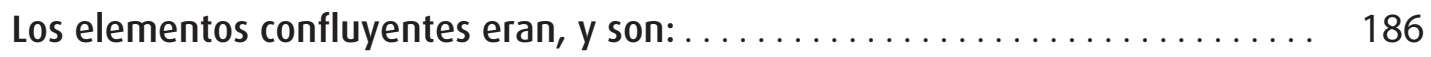

Bibliografía ...................................... 189 


\section{Introducción}

Esta tesis opta por el formato de "informe de situación", del "estado presente de un proceso en tránsito" ${ }^{1}$, dadas las condiciones de posibilidad y de oportunidad que, siempre, una tesis constituye. Coincidimos con el maestro Jesús Martín Barbero que "frente al idealismo -discurso sin materia, sin objeto-, frente al materialismo -discurso sin sujeto-, planteamos el discurso práctico: lugar en que la lengua se carga y es cargada de pulsión"2.

Si el Discurso es Poder y no sólo escenario en donde se representa una lucha por él sino que forma parte de sus condiciones de oportunidad, posibilidad, producción y circulación, presento aquí una propuesta de ordenamiento de una historia que, paradigmática, hace faro, equilibrio y sentido de los procedimientos de autorización, de evaluación, de acreditación, de control, de inclusión, de exclusión, de ritualización y mitificación, de consolidación, de censura, de ocultamiento, de desaparición, con que está construido este poderoso proyecto de desarrollo con que damos batallas nada metafóricas tanto en esto de la Comunicación del Conocimiento, como en el Conocimiento de la Comunicación.

En fin, una "visión instantánea que nos haga descubrir lo desconocido, no en una lejana terra incognita, sino en el corazón mismo de lo inmediato", tal como decía Rimbaud ${ }^{3}$ o, en otras palabras, un ejercicio de reflexividad epistemológica sobre y en mi lugar de producción académica.

\footnotetext{
1 GIORDANO, Carlos J. Tesis

2 MARTÍN BARBERO, Jesús. “Procesos de comunicación y matrices de cultura” Itinerario para salir de la razón dualista. “De la transparencia de los discursos a la opacidad del mensaje" FELAFACS. Barcelona, 1988.
} 


\section{Aclaración estructural}

La tesis contempla tres grandes partes transversales que, conceptualmente, pueden definirse como:

1. descripción densa del devenir resultante;

2. caracterización contextualizada de prácticas y saberes operantes;

3. crítica propositiva, curricular, política.

Previo a ellas, presentamos las explicaciones de lo metodológico, es decir aquello que hemos realizado para datar, mensurar, calificar, definir y pensar cada párrafo, cada afirmación, cada categorización, la conclusión.

\section{Afirmaciones metodológicas}

La tesis está signada por el interés de producir conocimiento articulador sobre, y de, prácticas y saberes transdisciplinarios sobre un caso de institucionalidad. En este sentido, nos desprendemos de los abordajes hipotético/deductivos, naturalista/comprensivos o teórico/formalistas, en favor una intervención construccionista/dialéctica. Un conocimiento verosímil, transferible y abierto a "dependibilidad" respecto al campo de observación y desarrollo, abierto a la emergencia y la inmediatez más que a la satisfacción de criterios predigeridos. Una ruptura como operación fundamental de esta perspectiva epistemológica crítica.

Es que se trata de un "objeto" definido y elaborado socialmente al que complejizamos y reconstruimos en un sistema de relaciones pertinentes y específicas que nos permiten superar el "efecto de censura estructural"4 de Bourdieu. Es decir lo indecible, lo innombrable, lo inhibido. La ruptura implicó vigilancia epistemológica y revisión de aquellas "síntesis fabricadas" (conceptos y relaciones) para historizar socialmente el problema de nuestro pensamiento. 
Una historia del trabajo que, social, construye instrumentos de construcción de la realidad social. Parafraseamos a Bourdieu y decimos que esta historia no nace por un interés de anticuario o copista, sino de un profundo deseo de entender por qué y cómo y qué entendemos.

Esta tesis deconstruye un objeto definido y elaborado como hecho, informado socialmente en una operación doble: por el sentido común y por el trabajo de analistas profesionales; está preconstruido, es significativo, como dicen los semiólogos. Por eso, el imperativo ha sido establecer esta posición de ruptura con los hechos que vienen "dados", con los discursos que suelen confundirse con lo concreto, mientras que éste es producto de una formidable abstracción, y cualquier desviación "empirista" podría desconocerlo como tal. Hemos ido y venido, aprendiendo a dónde tenemos que ir, dijo Theodore Roethke 



\section{Devenir denso Descripciones}

En esta primera parte de la tesis, damos cuenta de cuatro componentes indispensables para la condición de posibilidad del "hecho" paradigmático de la Facultad de Periodismo y Comunicación Social de la UNLP: Primero reescribimos como una continuidad la historia institucional, desde las tensiones fundantes (que siguen siendo las presentes) y las posibilidades organizacionales, hasta las estructuraciones de los estudios específicos en el panorama nacional; en segundo término, concentramos en apretada síntesis algunos instrumentos de políticas públicas que sustentan materialmente mucho de lo posible y lo deseable para el desarrollo del "específico comunicacional"; el tercer paso de esta densidad, caracterizamos desde un diálogo de saberes en permanente acción, la situación de nuestros jóvenes estudiantes (más allá de las edades cronológicas) respecto de las problemáticas tensas de sus formaciones y un cuarto momento en el que planteamos los sentidos de la teoría que usamos para intervenir en todo el escenario de las convergencias tecnológicas y los saberes compartidos.

\section{Rehistorización instituyente}

"En la medida en que el espacio de comunicación se torna cada día más estratégico, decisivo para el desarrollo o el bloqueo de nuestras sociedades -como revela la densa relación entre violencia e información, la incidencia de los medios en la legitimación de los regímenes de populismo autoritario, y de nuevas tecnologías en la reorganización de la estructura productiva, de la administración pública e incluso en la estructura de la deuda externa- se hace más nítida la demanda social de 
un comunicador capaz de enfrentar la envergadura de lo que su trabajo pone en juego y las contradicciones que atraviesan su práctica (...) Frente a la crisis de la conciencia de que en comunicación se juega de manera decisiva la suerte de lo público, la supervivencia de la sociedad civil y de la democracia".

Jesús MARTín BARBERO

Describir el escenario actual del campo, proponer la formación del comunicador del futuro: capaz de asumir los diversos desafíos del presente. Iniciar con un recorrido histórico de la formación académica en comunicación desde la institución que me constituyó, de la que soy parte como docente e investigadora: la Facultad de Periodismo y Comunicación Social de la Universidad Nacional de La Plata; con ochenta años de trayectoria. Los invito a revisar la historia, a reflexionar sobre el presente y a pensar juntos el futuro de las carreras de comunicación.

La Facultad de Periodismo y Comunicación Social de la Universidad Nacional de La Plata transita su séptima década. Su historia es el registro de la formación de miles de profesionales. Y su futuro constituye una proyección atenta a fortalecer la responsabilidad académica y el compromiso profesional en cada uno de sus estudiantes, docentes e investigadores. Desde sus inicios como Escuela Superior de Periodismo en la década de 1930, la FPyCS experimentó un importante y progresivo crecimiento institucional y académico. Allí, logró conjugar enseñanza, investigación, docencia y extensión, fundamentalmente desde octubre de 1994, cuando el Consejo Superior de la UNLP aprobó su pase a Facultad. Actualmente, un promedio de 1300 alumnos comienzan anualmente sus estudios en esta unidad académica. Se dictan en ella la Licenciatura en Comunicación Social, con orientaciones optativas en Periodismo y en Comunicación Social, el Profesorado en Comunicación Social y la Tecnicatura Superior en Periodismo Deportivo y la Tecnicatura en Comunicación Popular.

En la Argentina que estaba terminando el siglo XIX, el impulso inicial fue la preocupación por mejorar lo que todos daban por un oficio necesario y amenazado por una modernidad tecnológica que empezaba a angustiar tempranamente. El 27 de abril de 1934 comenzaron unos cursos de aquel periodismo oficioso, que desde el comienzo estuvieron vinculados con la Universidad Nacional de La Plata. 


\section{Contextos editoriales}

Argentina, en la década del ' 30 , era la catástrofe institucional radiografiada por Ezequiel Martínez Estrada y era también "Los siete locos" de Roberto Arlt. Era el Presidente Yrigoyen derrocado por el General José F. Uriburu, mediante el primer Golpe militar contra un gobierno electo por los votantes autorizados. Y la prensa, como siempre, pero jugando fuerte, asintió: “Camaradas: El Ejército y la Armada de la Patria, respondiendo al clamor unánime del pueblo de la Nación y a los propósitos perentorios que nos impone el deber de argentinos en esta hora solemne para los destinos del país, han resuelto levantar su bandera para intimar a los hombres que han traicionado en el gobierno la confianza del pueblo y de la República, el abandono inmediato de los cargos, que ya no ejercen para el bien común, sino para el logro de sus apetitos personales. (...) La misma Constitución obliga a los ciudadanos a armarse en su defensa. Ha llegado el momento. ¡A las armas! para salvar la realidad de las instituciones y la dignidad de la Nación", dijo.

Poco después, el 4 de junio de 1933, fallece ese mismo Hipólito Yrigoyen. El diario La Prensa dirá: "Ha muerto demasiado tarde”. Si había dudas, aquel periodismo ya se parecía demasiado a sí mismo.

\section{Aprender lo aprendido}

El grupo que dirigía el Círculo de Periodistas de la Provincia de Buenos Aires, periodistas de "oficio", vio y planteó la necesidad de estudios sistemáticos que formaran en saberes críticos, más universales e integrales que las descripciones llanas de la anécdota puntual reciente.

En una asamblea extraordinaria realizada el 25 de Septiembre de 1933, a propuesta de la Comisión Directiva, el Círculo de Periodistas de la Provincia de Buenos Aires, resolvió promover el establecimiento de cursos preparatorios y de perfeccionamiento para la profesión de Periodismo "a fin de fomentar y facilitar una mayor y mejor preparación profesional de sus socios y para incorporar al gremio, en el futuro, personas capacitadas para la moderna labor periodística.

Con tal propósito, esta Asamblea autorizó a la Comisión Directiva a determinar el plan de los Cursos y las condiciones de su instalación; a efec- 
tuar los gastos que ellos originasen y a convenir con la Universidad Nacional de La Plata, $u$ otras entidades culturales, los medios y formas de una colaboración recíproca para la puesta en marcha de tamaña iniciativa"6. Expresamente se declaró que ella tenía el carácter de ensayo y previa investigación a fin de establecer si existía interés público y condiciones favorables en el ambiente social para la futura fundación de una Escuela de Periodismo, a la vez que para determinar cuáles serían las disciplinas y enseñanzas profesionales que habrían de constituir su futuro plan de estudios.

Cumpliendo estas disposiciones, la Comisión Directiva, presidida por el Dr. Manuel Eliçabe -periodista del Diario La Prensa-, e integrada por Carlos Molteni de “La Nación", Edgardo Saborido e Ignacio Fernández también de "La Prensa", Luis Aznar de "La Vanguardia", Ramón T. García y Alfredo Fernández García de "El Argentino", Juan Carlos Olmedo Varela de la Agencia de Noticias "A.N.D.I.", Manuel Vega Segovia y Saverio Redoano del diario "El Día", resolvió abrir públicamente un registro de inscripción de asistentes a los cursos a iniciarse, constatar regularmente la concurrencia de los inscriptos y promover, de acuerdo con el Presidente de la Universidad Nacional de La Plata, Dr. Ricardo Levene, la serie de conferencias y cursos a dictarse durante el año lectivo.

Como ya quedó dicho, los cursos comenzaron a dictarse el 27 de abril de 1934, con casi 300 alumnos inscriptos. Al iniciarse el primer bimestre, el presidente del Círculo, Manuel Eliçabe, explicó el fundamento de su propósito y dimensionó la importancia de dicho acontecimiento. Perfilando un diagnóstico de la actividad periodística, expresó que "la aceleración del ritmo de la vida contemporánea ha exigido al periodismo la mayor universalidad de la información noticiosa y de su comentario y le ha impuesto la condición de la más estricta actualidad. Según una feliz expresión -agregó- el público lector es un ser fugitivo que el periodista debe cazar cada día. Adversos a la universalidad y actualidad de la labor periodística, los factores distancia y tiempo se reducen a su mínima expresión por la velocidad que engendran la preparación profesional y la atinada utilización de los medios modernos de comunicación. 
Al alcance de todos, por lo general, están los últimos; mas la preparación profesional exige arduo aprendizaje previo, que desarrolle y cultive las actitudes originarias; impone la adquisición de conocimientos variados, la vivacidad y el perfecto dominio técnico del complicado mecanismo del diario moderno"7

Ese aprendizaje, según Eliçabe, en la Argentina y hasta ese momento, se realizaba en los mismos diarios y durante el ejercicio de la profesión, exigiendo a quienes se iniciaban, que se improvisaran idóneos en el mismo campo de trabajo. Denominó, también, a los diarios La Prensa y La Nación, como dos grandes escuelas de periodismo; escuelas que -según sus palabras- habían llegado a un alto grado de perfeccionamiento por aquellos años, aunque los métodos originarios no habían variado y los inconvenientes del sistema se hacían manifiestos para los mismos diarios y para quienes aspiraban a ejercer el oficio.

"Cientos y cientos de jóvenes desfilan por los diarios argentinos todos los años y sólo muy pocos se afirman en la profesión. En los diarios se aprende, pero la enseñanza no está metodizada y el aprendizaje se hace a costa del diario. Y no sé que a ninguna persona discreta se le ocurra facilitar a un joven aspirante a mecánico, un espléndido y flamante motor de gran costo para que aprenda manejarlo"8

Este mismo estado de opinión sucedía en otras partes del mundo. El profesor Strowski, en el diario "Paris-Soir", auspició en 1927 la idea de fundar en La Sorbona, un instituto para la formación de periodistas porque, decía, "se haría ganar 10 años de vida al periodista si, en lugar de los largos tanteos profesionales a que se someten hasta llegar a su madurez, sin más guía que el instinto o la práctica, se establece una enseñanza metódica para ellos".

También Otto Groth, en "Die Setung”(1928), preconiza esta solución. La mayor parte de las naciones europeas la fueron adoptando, movidas por la necesidad de contar con periodistas de verdadera preparación profesional. La "Gran Guerra" les había revelado la importancia de pro- 
veer a tal necesidad. Francia, Alemania, Inglaterra y Rusia habían implantado o estimulado el funcionamiento de escuelas de periodismo. Italia había incorporado estudios de periodismo a su vasto plan de enseñanza profesional y reglamentado el ejercicio de la profesión.

En esta dirección, los Estados Unidos se habían anticipado a los países europeos en muchos años. A mediados de la década del 30, ya contaban con más de 100 institutos especiales de periodismo y 300 universidades y Colegios que ofrecían cursos de esta profesión, mientras que en Sudamérica no existía ninguno que cubriera esta necesidad.

En nuestro país, con anterioridad, hubo algunos intentos fallidos. El Primer Congreso de la Prensa Nacional, reunido en mayo de 1901, por iniciativa de Estanislao Zeballos, Manuel Carlés, Ezequiel P. Paz y Emilio Mitre y Védia, resolvió la fundación de una Universidad Libre y Escuela de Periodismo, pero finalmente esa iniciativa no se llevó a cabo.

La falta de un instituto para la formación de periodistas había sido notada frecuentemente. En 1931, el decano de la Facultad de Filosofía y Letras de la Universidad de Buenos Aires, Norberto Piñero, en una carta dirigida al Círculo de Periodistas recordaba que, como Decano, se propuso crear una Escuela de esta índole con la colaboración de algunos grandes diarios.

También el Dr. Ricardo Levene, Presidente de la Universidad Nacional de La Plata en el período que abarcó 1934, siendo Decano por segunda vez de la Facultad de Humanidades y Ciencias de la Educación, tuvo igual pensamiento ya que consultó un proyecto de Escuela de Periodismo a algunos periodistas platenses.

\section{Lo concreto del inicio}

Con estos antecedentes, en pocos días, 300 jóvenes se inscribieron y Manuel Eliçabe no olvidó saludar con agrado a las 90 mujeres que lo hicieron. Para el Círculo de Periodistas, la meta de los cursos debía incluir investigar cuáles serían las disciplinas científicas y las enseñanzas profesionales que habrían de constituir el futuro plan de estudios. Sin establecerlas a priori, se lograrían consultando a los mismos inscriptos "auscultando sus aspiraciones para satisfacerlas en cuanto sea racional y 
legítimo; acogiendo las más autorizadas opiniones de los humanistas y de los grandes periodistas de la época", para determinar, con el concurso de todos, cuál sería el plan definitivo.

\section{Los cursos iniciales}

- "Panorama del periodismo contemporáneo" a cargo del Profesor José A. Oría, "Reportaje y redacción de noticias” dictado por Ramón T. García,

- "Iniciación en el Arte Tipográfica aplicada al periodismo" por Mario Sciocco, "Organización Nacional. 1852-1862" por Carlos Heras y

- “Sociología Iberoamericana" por el Dr. José A. Vasconcelos.

En la segunda mitad de 1934, se dictaron

- "El periodismo argentino entre los años 1820 y 1830" a cargo del Dr. Arturo Capdevila,

- "Literatura contemporánea de la América Española" por el profesor Pedro Enríquez Ureña,

- "Instituciones coloniales de la América Española" por el catedrático de la Universidad de Sevilla Dr. José María Ots Capdequí,

- "Estudios de artículos periodísticos, su análisis, crítica y reconstrucción" a cargo de Manuel Eliçabe.

Además se hicieron visitas a los diarios de La Plata y de Capital Federal y se agregaron algunas conferencias referidas al ejercicio de la profesión. Todos los cursos fueron dictados en forma gratuita y quienes estuvieron al frente de los mismos lo hicieron en forma ad-honorem.

Luego de una larga negociación que se inició al dictarse los cursos libres de periodismo durante 1934, el 7 de mayo de 1935 la presidencia del Círculo de Periodistas de la provincia de Buenos Aires, dirigió una extensa comunicación, autorizada por la Comisión Directiva, al presidente de la UNLP, Dr. Ricardo Levene, destacando la necesidad y las ventajas de la creación de la Escuela Argentina de Periodismo, solicitando la colaboración de la Universidad para realizarla y proponiéndole las bases de esa creación, las normas para su gobierno, el plan mínimo de estudios y la forma de arbitrar recursos para su sostenimiento. Luego de algunas modificaciones, la Universidad dictó la ordenanza donde se acordó el auspicio y la colaboración para la puesta en marcha de la nueva Escuela. 
Bajo este acuerdo se inscribiría a los alumnos en carácter de "oyentes", otorgándoles certificados, previa aprobación de los exámenes de Composición y Gramática, Historia Argentina Contemporánea, Geografía Política y Económica Argentina, Idioma, Derecho Constitucional, Sociología, Derecho Administrativo y Derecho Internacional Público, que se dictaban en la Facultad de Humanidades y Ciencias de la Educación y también en la de Ciencias Jurídicas y Sociales de la UNLP. Por otra parte, el Círculo de Periodistas se comprometía a dar enseñanza teórica y práctica a través de asignaturas específicas: Historia del Periodismo, Reportaje y Redacción de Noticias, Estudio de originales periodísticos, su crítica y reconstrucción, Arte Tipográfico aplicado al Periodismo, Legislación de Prensa y Ética Periodística. Por su parte, el Presidente de la Universidad designaría una Comisión que dictaría el Reglamento de la Escuela.

La Comisión fue presidida por el mismo Levene e integrada por Manuel Eliçabe (Presidente del Círculo), José A. Oría (Profesor de la Facultad de Humanidades y Ciencias de la Educación) y los periodistas Ramón T. García y Carlos R. Molteni. Esta Comisión redactó el reglamento que contenía 16 artículos, en los que hacía referencia -entre otras cuestiones- a que una Comisión de Gobierno, compuesta por un Director y dos Vocales, tendría a su cargo el gobierno técnico y administrativo de la Escuela. Dicha Comisión, además, podía estar integrada por un delegado del Centro de Estudiantes, siempre que éste lo solicite, quien podría emitir opinión sobre toda clase de asuntos a tratarse, pero no tendría voto resolutivo sobre ellos. El Director sería nombrado por la Comisión Directiva del Círculo de Periodistas, siendo su mandato por 4 años, y los Vocales -con 2 años en sus funciones- serían nombrados uno por el Presidente de la UNLP y el restante por la comisión Directiva del Círculo.

Durante los años siguientes, el número de inscriptos fue en aumento, de los cuales el 30\% seguía representado por mujeres. Un promedio de 45 alumnos fue aprobado al final de cada año lectivo y durante el año 1937, la Escuela recibió la visita del Decano de la "Escuela Graduada de Periodismo" de la Universidad de Columbia, New York, Dr. Carl W. Ackerman, quien, además de interesarse por ella e informarse de su plan de estudios, programas y reglamento, disertó en aquella oportunidad sobre “La función del periodismo y su influencia en la paz y armonía de las na- 
ciones", en el Aula Magna de la Facultad de Humanidades y Ciencias de la Educación de la UNLP.

En el año 1943, la Comisión de Gobierno de la Escuela, resolvió reformas en el Plan de Estudios, elaborado inicialmente de común acuerdo entre la Universidad y el Círculo. En su petitorio, la Comisión solicitaba a la Universidad auspicios más eficaces que los que se habían brindado hasta ese momento, y se notificaban las modificaciones previstas, en donde se agregaban asignaturas como "Ilustración de periódicos" y "Reportaje gráfico" (dibujo, grabado, litografía, fotograbado, belinogramas) por un lado, materias de las que se haría cargo el Círculo, en colaboración con los cursos y laboratorios de la Escuela de Bellas Artes de la UNLP, además de las materias "Administración de periódi$\cos ^{\prime}$ y "Publicidad, avisos y propaganda comercial". Y, por otro lado, se agregaban cátedras de estudios superiores y perfeccionamiento en las facultades de Humanidades y Ciencias de la Educación y la de Ciencias Jurídicas y Sociales.

La necesidad de dictar cursos básicos por un lado y superiores o de perfeccionamiento por el otro, respondía a exigencias reales, tales como que la Escuela ofreciera puntos de interés no solamente a los aprendices sino también a los ya profesionales y veteranos del periodismo, para quienes cabe suponer "innecesarias o poco atractivas las enseñanzas elementales", según la documentación de la época. Por otra parte, se advertía la "conveniencia social de dar posibilidad de ocupación honrosa y remunerativa a la gran cantidad de jóvenes que, por no haber podido o haber realizado oportunamente estudios secundarios, o no haber podido iniciar estudios universitarios", tenían la posibilidad de acceder libremente a los cursos elementales de la Escuela y algunas de sus materias se volvían inaccesibles a su limitada preparación general.

Ante esto, el entonces Presidente de la UNLP, Dr. Alfredo L. Palacios, y el Consejo Superior, el 22 de junio de 1943, aprobaron el plan de reformas y establecieron que el reglamento de 1935 se mantenía en vigencia, los alumnos quedaban equiparados a los de la Universidad en los beneficios de ayuda social, previo pago de los derechos respectivos y se modificaba el plan de estudios que incluía "cátedras básicas para los 
alumnos regulares y cátedras de estudios superiores y de perfeccionamiento, de asistencia facultativa, para alumnos de la Escuela o periodistas profesionales", tal como fuera solicitado en el proyecto.

La Escuela, que desde su nacimiento dictaba clases en forma gratuita y su personal docente y administrativo desempeñaba sus funciones sin cobrar salarios, era sostenido por el Círculo. En el año 1941, el Diputado Nacional Dr. Raúl Díaz, había presentado ante la Cámara de Diputados un proyecto de Ley por el que se proponía dar a la Escuela una pequeña subvención económica. Dicha subvención, destinada en parte para la adquisición de las máquinas, tipos y accesorios de un taller de imprenta, no obstante su incorporación al Presupuesto Nacional de los años 1941 y 1942, quedó sin cumplirse en razón del decreto de economías que el Poder Ejecutivo expidió para el ejercicio administrativo de aquellos años y recién se hizo efectiva la partida para 1943. Ante esta situación, la Comisión Directiva del Círculo, acudió en demanda de ayuda al Gobierno de la Provincia de Buenos Aires, cuyo Poder Ejecutivo, desempeñado por el Dr. Rodolfo Moreno, le acordó un donativo, por única vez, en marzo de 1943, cuyo importe, junto a las sumas disponibles de la subvención nacional, hizo posible la instalación del taller de imprenta que se aspiraba. Éste contó con una máquina "Ausburg" plana de imprimir, una linotipo de modelo 8B con tres almacenes, cajas y juegos de tipos variados, mesa de imponer, ramas, guillotinas, sacapruebas y otros accesorios indispensables para impresión de un periódico -que más tarde compusieron los alumnos- y de las cartillas de divulgación académica que la Escuela editó y difundió gratuitamente en el país. En aquella rudimentaria imprenta se editó, tiempo después, en 1946, "El Iniciador", un periódico escrito por los estudiantes de periodismo, de distribución gratuita.

La subvención, administrada por la Dirección y la Comisión de Gobierno de la Escuela, permitió además, asignar una modesta suma anual a las diversas cátedras y un sueldo al personal administrativo durante 1943, e instituir una "bolsa" para costear un viaje de estudios a los alumnos que más se destacasen en los cursos.

Pero este salvataje financiero no fue más que un paliativo temporario ya que la falta de sostén económico no fue definitivamente resuelta en los años siguientes. Ante este cuadro de situación, el Círculo comien- 
za a tramitar una gestión con la Universidad Nacional de La Plata, con el fin de lograr "la oficialización de la Escuela bajo la dependencia directa de esa casa de estudios". La incorporación definitiva de la Escuela a la Universidad, se formuló a través de un anteproyecto de bases que el Vicepresidente, Ing. Héctor Ceppi, resolvió someter a consideración del Consejo Universitario, en forma de memorando. A los fines de llevar a la práctica esta incorporación sería necesario establecer un convenio en el que se incluiría la transferencia a la Universidad del material didáctico con que contaba la Escuela y su taller de imprenta, previa estimación de su valor por peritos que designarían las partes para que se expidieran conjuntamente.

La Universidad se comprometía a mantener la estructura de la Escuela en sus lineamientos generales. Mantendría también en sus cargos a la Dirección, personal docente y administrativo y mejoraría las asignaciones que tenían los mismos en ese momento en su presupuesto, fijándose en principio, para el primer año de vida universitaria, haberes que en ningún caso serían inferiores al sueldo mínimo que reglaba en la UNLP. Además se obligaba a disponer todo lo necesario para que no sufriera interrupciones, entre otras cosas, la aparición del periódico que editaba la Escuela por entonces.

\section{La incorporación plena}

Fue recién en abril de 1954, cuando el Consejo Superior resolvió auspiciar el funcionamiento de una Escuela de Periodismo en la UNLP. Para ello dispuso designar una Comisión con el fin de elevar un proyecto de organización y funcionamiento, compuesta por el fundador Manuel Eliçabe, el director de entonces Saverio Redoano y Miguel Ángel Escalante.

Meses después, en septiembre de ese año, el Consejo aprobó el proyecto respectivo y con él la creación de la Escuela de Periodismo de la UNLP. Para concretarla, el Círculo ofreció sus aulas, elementos didácticos y el uso de su taller de imprenta, por 3 años prorrogables, hasta que la Universidad dispusiera de un presupuesto adecuado a sus fines. 
En Octubre de 1955 asumió sus funciones como Delegado Interventor en la Escuela el Dr. Pascual Cafasso, cargo que ocupó por más de 12 años. Durante su gobierno se aprobó un nuevo plan de estudios, en 1956, y se creó el Seminario de Investigaciones. En 1958, la Escuela se mudó al edificio de calle $53 \mathrm{~N}^{\circ} 726$-ex residencia del gobernador Udaondo- alquilado por la Universidad, dejando definitivamente las instalaciones del Círculo de Periodistas de la Provincia de Buenos Aires. Allí también se trasladó la imprenta, la biblioteca especializada, el laboratorio fotográfico, los grabadores y las máquinas de escribir.

En julio de 1961 apareció el primer número de "Noticias Universitarias", editado por la Escuela, que se convirtió en vocero de la Universidad platense y sirvió gratuitamente a docentes, administrativos, estudiantes y graduados. En 1964, el Consejo Superior de la Universidad aprobó un nuevo plan de estudios para la carrera de Periodismo, que convirtió al instituto en Escuela Superior y en 1965 las autoridades designaron nuevamente al Dr. Cafasso como Director.

En 1966, por primera vez, se resolvió crear un Consejo Asesor integrado por profesores, graduados y estudiantes, y en junio de ese mismo año se designó al Aula Magna de la Escuela con el nombre de Manuel Eliçabe en homenaje a su memoria.

A principios de los años '70, la Escuela Superior de Periodismo seguía en el mismo edificio, que ya estaba notoriamente deteriorado, el Plan de Estudios contaba con una Licenciatura en Ciencias de la Información ( 3 años) y un Profesorado en Comunicación Social (2 años más), sin tesis de graduación, pertenecientes al denominado Plan de Estudios 1969. En el primer año ingresaban cerca de 100 alumnos, en el tercero quedaba la mitad, mientras que al Profesorado lo terminaban entre $10 \mathrm{y}$ 15 de aquéllos.

Hasta el año 1973, la dirección fue ocupada con cierta continuidad institucional, siendo el Dr. Ataúlfo Pérez Aznar el último de este ciclo. A partir de ese año, comenzó una serie de conducciones erráticas producto de los vaivenes políticos de la época: por la Dirección pasaron un militante con antecedentes académicos, un médico y, por último, el presidente de un centro de jubilados. 
La precariedad de los sucesivos edificios ocupados y de los magrísimos presupuestos acordados complicó la situación de un cuerpo docente que contaba con la presencia de Silvio Frondizi, Gregorio Selser, Horacio Bertholet, Guillermo Savloff y Sergio Karakachoff, entre otros prestigiosos intelectuales comprometidos con ideales de transformación, aún de su propia función.

Estos límites no fueron superados al pasar al edificio de calle 44 $N^{\circ} 676$, puesto que casi al mismo tiempo que la mudanza, el país comenzó el período más negro de su historia. El 24 de marzo de 1976, una alianza cívico-militar derrocó al gobierno constitucional y se institucionalizó la política del Terrorismo de Estado como norma de convivencia nacional.

Aquí la prensa y ya los medios de comunicación en general tendrán decisiva participación en los acontecimientos de los años más oscuros del país. Rastreos históricos sobre la posición de los medios pueden hacerse en millares de páginas escritas y aún en los documentos que los propios medios proporcionan. Sin embargo, para una cabal comprensión de esta situación, sigue siendo paradigmática la Carta Abierta de Rodolfo Walsh que, el 24 de marzo de 1977, dirigió al gobierno en la figura de la Junta Militar:

“(...) 1.La censura de prensa, la persecución a intelectuales, el allanamiento de mi casa en el Tigre, el asesinato de amigos queridos y la pérdida de una hija que murió combatiéndolos, son algunos de los hechos que me obligan a esta forma de expresión clandestina después de haber opinado libremente como escritor y periodista durante casi treinta años.

"El primer aniversario de esta Junta Militar ha motivado un balance de la acción de gobierno en documentos y discursos oficiales, donde lo que ustedes llaman aciertos son errores, los que reconocen como errores son crímenes y lo que omiten son calamidades.

"El 24 de marzo de 1976 derrocaron ustedes a un gobierno del que formaban parte, a cuyo desprestigio contribuyeron como ejecutores de su política represiva, y cuyo término estaba señalado por elecciones convocadas para nueve meses más tarde. En esa perspectiva lo que ustedes liquidaron no fue el mandato transitorio de Isabel Martínez sino la posibilidad de un proceso democrático donde el pueblo remediara males que ustedes continuaron y agravaron. 
"llegítimo en su origen, el gobierno que ustedes ejercen pudo legitimarse en los hechos recuperando el programa en que coincidieron en las elecciones de 1973 el ochenta por ciento de los argentinos y que sigue en pie como expresión objetiva de la voluntad del pueblo, único significado posible de ese "ser nacional" que ustedes invocan tan a menudo.

"Invirtiendo ese camino han restaurado ustedes la corriente de ideas e intereses de minorías derrotadas que traban el desarrollo de las fuerzas productivas, explotan al pueblo y disgregan la Nación. Una política semejante sólo puede imponerse transitoriamente prohibiendo los partidos, interviniendo los sindicatos, amordazando la prensa e implantando el terror más profundo que ha conocido la sociedad argentina.

"2. Quince mil desaparecidos, diez mil presos, cuatro mil muertos, decenas de miles de desterrados son la cifra desnuda de ese terror (...)".

Al día siguiente del envío de la Carta, el 25 de marzo de 1977, un comando militar enviado desde la Escuela de Mecánica de la Armada, emboscó a Rodolfo Walsh, lo hirió gravemente y lo incorporó a la lista de desaparecidos que el propio periodista, escritor y revolucionario había detallado un día antes.

Mientras tanto, en La Plata, algunos días antes, el 26 de junio de 1976, el rector interventor de facto Médico Veterinario Guillermo Gallo, nombró al Licenciado en Psicología Daniel Alfredo Pabón, que ya era docente, como Director. Esta decisión fue avalada por los docentes con más predicamento en la Escuela de Periodismo, con la convicción de que "era mejor un miembro del equipo, de la institución, que diera el perfil" antes que una intervención totalmente externa. Todo aquel equipo permaneció en la Institución y durante su administración desaparecieron y fueron asesinados 34 docentes, no docentes, estudiantes y graduados?

9 Silvio Frondizi, Julio Alberto Álvarez, Ricardo Emir Aiub, Horacio Félix Bertholet, Néstor Alejandro Bossi, Ricardo A. Díaz Anselmi, Daniel Rodolfo Elías, José G. Espinoza Pesantes, Roberto Nando Falivene, Jorge Horacio Foulkes, María Teresa Grujic de Coronel, Alejandro E. Gutiérrez Penette, Silvia Elvira Ibáñez, Carlos E. Ishikawa, Juan Carlos Jordán Vercellone, Liliana Edith Molteni, Mercedes Isabel Maiztegui, Héctor M. Marghetich, Elsa Delia Martínez, Susana Beatriz Medina, Norberto Juan Orlando Tilot, Pablo Andrés Gelstein Barretic, María Fernández de Pankonin, Rafael Antonio Pedreira, Victoriano Graciano Perdighe, Guillermo Savloff, Nélida Ofelia Villarino, Sergio Zurita, Rodolfo Company, Susana García, Carlos Enrique Sentrece, Sergio Karakachoff, Jorge R. Harriague, Luis Norberto Macor. 
En lo específico institucional, por resolución del 31 de Diciembre de 1976, se cambió la denominación de la Escuela pasándola a Escuela Superior de Periodismo y Comunicación Social, se reformó el Plan de Estudios determinando una Licenciatura en Comunicación Social (con tesis) de cinco años y un título intermedio de Periodista (a los 3 años), se creó el Instituto de Investigación de la Comunicación Social y, como ya quedó dicho, se propició la mudanza desde el viejo edificio de la calle 10 entre 54 y 55. También, en carácter de institución fundadora desde el 29 de octubre de 1981, pasó a formar parte de la Federación Latinoamericana de Asociaciones de Facultades de Comunicación Social (FELAFACS).

En toda la década, salvo emprendimientos individuales, la Escuela nunca salió a la calle con ningún producto periodístico ni académico, salvo una publicación que sigue pareciendo exótica a la especificidad: un folleto reivindicatorio de algunas ideas en torno a la soberanía argentina sobre las Islas Malvinas, con escaso valor académico y nulo contacto con cualquier práctica o saber vinculado al periodismo y la comunicación social, firmado por el psicólogo Daniel Pabón.

\section{La historia reciente}

El regreso a la vida democrática a partir de 1983 tuvo, en nuestra Institución, la misma gradualidad, las mismas tensiones y transiciones, que el conjunto de la Nación. En un contexto de fuerzas que propugnaban por mantener los privilegios y los sentidos y fuerzas que representaban las necesidades de transformación en todos y cada uno de los campos, la Escuela Superior de Periodismo y Comunicación Social no fue la excepción sino la estricta confirmación de la regla. Luego de tanta muerte y desapariciones, la vida volvía a estar en germen y todo se demostraba asumible: la memoria, la justicia, pero también las cruciales contradicciones del cambio de época, de paradigma, de sentido, y de la correlación de fuerzas. También estaba en tensión la etapa en que la enseñanza del periodismo y la comunicación abandonaba para siempre su carácter de transmisor de prácticas profesionales exclusivamente y se convierte, también, en un ámbito convocante a los pensamientos complejos, a la conceptualización de los procesos, al análisis de los discursos 
y a la crítica sobre los medios. La responsabilidad social del periodismo y de los medios de comunicación volvía al centro de la cuestión y un conjunto activo de estudiantes, algunos graduados y pocos profesores reclamaban nuevas reglas institucionales que, modificando aquel presente áulico, contribuyera a la indispensable transformación sociopolítica colectiva. Con este magma, la comunidad educativa de la Escuela Superior de Periodismo y Comunicación Social con una mayoría proveniente de los planteles educativos de los años 76-83, y en el proceso de normalización universitaria, eligió a Carlos Bustamante como el primer Director de su historia y pronto se abrió un período que tuvo en Jorge Bernetti, siguiente Director electo, la cara visible de una fuerza política juvenil que pugnaba y protagonizó luchas por la jerarquización profesional, institucional y epistemológica.

El 24 de octubre de 1994 el Consejo Superior de la UNLP cambió el estado de la Escuela Superior de Periodismo y Comunicación Social. En una votación unánime, concluyó en el pase de Escuela Superior a Facultad poco tiempo después del sexagésimo aniversario de la creación de los Cursos en 1934.

Este "pase" abrió una nueva etapa en la que aparecieron con fuerza otros objetivos y otras necesidades. En todas las áreas se impuso una transformación estructural considerada imprescindible para consolidar de pleno derecho la inserción definitiva en el contexto del sistema universitario en general, y de la UNLP en particular. La puesta en marcha del cogobierno efectivo, el desarrollo de la investigación y la extensión, la autonomía presupuestaria, fueron los instrumentos relevantes en donde lo identitario se manifestó, potente y vital, dentro de los difíciles laberintos del "pertenecer" a la UNLP, aunque también en un concierto de Instituciones y organizaciones que han hecho del "periodismo" y o la "comunicación" su razón.

Antes de entrar en lo específico, aporto un detalle superficial de los datos más destacables tanto de la UNLP como del "campo" de los estudios en periodismo y o comunicación. 


\section{Contextos}

\section{La Universidad Pública en los '90}

En julio de 1995 fue sancionada la Ley de Educación Superior (LES) № 24.521. En ella se disponían artículos en donde se mencionaba, entre los puntos más destacados, la posibilidad del ingreso restringido (Art. 35 y 50), del arancelamiento (Art. 50 y 59), de la autonomía universitaria (Art. 29 y 59) y la promoción de las universidades privadas (Art. 62). Las pautas de los Organismos Financieros Internacionales fueron incluidas en las principales líneas de la política educativa universitaria en la Argentina de los noventa por parte de los sucesivos gobiernos constitucionales.

Efectivamente, el Banco Mundial se constituyó en impulsor de las reformas de cuño neoliberal para la Universidad. Estas medidas tenían como objetivo disminuir el gasto estatal para derivar los fondos al pago de la deuda externa. El gobierno argentino, tal como lo señala Adriana Puigross aceptó todas las directivas del Banco plasmadas en los siguientes documentos:

- El financiamiento de la educación en los países en desarrollo, Washington, D.C., Banco Mundial, 1986;

- Prioridades y estrategias para la educación, Washington, D.C., Banco Mundial, 1995. Carnoy, Martín; Moura Castro, Claudio, “¿Qué rumbo debe tomar el mejoramiento de la educación en América latina?" , Documento de 8 antecedentes para el Banco Interamericano de Desarrollo, Seminario sobre Reforma Educativa, BID, Buenos Aires, 21 de marzo de 1996.

Puiggrós, hoy diputada nacional resume la política educativa en el ajuste de la educación al programa económico neoliberal teniendo en cuenta los siguientes aspectos y manifiesta que la estrategia consiste en:

"Disminuir la responsabilidad del Estado como financiador y proveedor de educación pública.

Establecer aranceles o subsidios privados en todos los niveles y modalidades, comenzando por la universidad y terminando por la educación básica.

Achicar el sistema de educación pública hasta el mínimo posible, mediante: o La transferencia de los establecimientos a jurisdicciones menores (de la 
Nación a las provincias y de estas, a las municipalidades), tendiendo a su privatización. o Reducción de modalidades que no dan rédito económico inmediato, como la educación de adultos y de materias del currículo como música, educación cívica y plástica, lo cual se ha llevado a cabo ya en algunas provincias; o Descuido de la educación para discapacitados; o restricciones sociales y territoriales en la extensión del servicio de educación pública"10 (Puiggros, 1996, 2: 141).

En Latinoamérica, las políticas que se aplicaron para el sector y el consecuente cambio de estilo en la relación gobierno-educación superior se fundamenta en el diagnóstico de la crisis del modelo universitario vigente, cuya manifestación más evidente fue: a) la pérdida de calidad de las universidades fruto de una doble presión; b) el aumento explosivo de la matrícula y c) la imposibilidad de financiamiento incremental por parte del Estado ante la crisis y el ajuste de los '80 (Brunner, 1993) ${ }^{11}$.

Sin embargo, estas nuevas políticas fueron incorporadas de manera diferencial en las instituciones.

\section{La UNLP}

La Universidad Nacional de La Plata es la institución símbolo de la ciudad, aunque sin lugar a dudas, la magnífica Catedral, el Teatro Argentino, el Estadio "Único", las camisetas "pincharratas" y "triperas" del fútbol profesional, la República en miniatura de los Niños, las plazas cada seis cuadras, las diagonales laberínticas, la Memoria de las luchas antidictatoriales que prohijó a Madres, Abuelas e HIJOS o los ex combatientes de Malvinas, los edificios remozados del poder político o el trazado pretendidamente perfecto de sus calles, también la distinguen.

La Plata es esta ciudad compleja y aún, felizmente, no completa, que forma "en varias filosofías (...), que prepara a sus hijos para dispersarse por el mundo, pero que a su vez atrae sistemáticamente a otras culturas, (...) que es mucho menos homogénea que lo que se ha dicho al

10 PUIGGRÓS, Adriana (1996, 2), Qué pasó en la educación Argentina. Desde la conquista hasta el Menemismo, Kapelusz, Buenos Aires. (Puiggrós, 1996,2: 141).

11 BRUNNER, JOSE JOAQUIN (1990) Gobierno universitario: Elementos históricos, mitos distorsionadores y experiencia internacional. En: Cox, Cristian (ed.), Formas de gobierno en la educación superior: nuevas perspectivas, FLACSO, Santiago de Chile. 
estereotiparla como ciudad de clase media, una ciudad de la que luego -afuera- uno se da cuenta en qué medida nos ha hecho vivir la multiculturalidad como núcleo conflictivo de la vida democrática"12. Y esta multiculturalidad está originada no en su origen proyectual, no en la visión modernista de su destino capitalino, sino en las oleadas migratorias e inmigratorias que permitió, cobijó, potenció, formó e integró la Universidad Nacional en sus alcances más profundos y amplios.

Esta Universidad que, aún en sus más duros años de desencuentros con los caminos emprendidos por la historia de nuestro Pueblo, fue asumida -como corresponde a una institución vívida-como lugar de encuentro, de debate democrático, o de resguardo humanista. Que, también, ante las Dictaduras, la represión y el Terrorismo de Estado, asumió oscuramente una función institucional acorde con éstos. Y que en los períodos de libertad democrática inspiró formidables movimientos de raíz popular, humanista y efectivamente científica, con nombres y acciones que disiparon y disipan radicalmente los fundamentos arcaicos y oscurantistas de su propio seno.

La Universidad Nacional de La Plata ha nacido, crecido, madurado y vive diseminada no sólo en el recorte del mapa de la ciudad y la región, sino en la trascendencia aún de las fronteras nacionales. Entonces, la concepción de identidad no se limita a la cuestión geográfica, sino que está simbolizada por la pasión educadora, la voluntad creativa y el impulso transformador de sus acciones, de sus personas y de sus visiones proyectuales.

La Universidad Nacional de La Plata fue fundada en 1905 por el doctor Joaquín Víctor González y se erigió sobre la base de la Universidad Provincial y de Institutos de Estudios que venían desarrollándose desde fines del siglo XIX.

Abreva en dos tradiciones fundantes: la Universidad, en su sentido histórico más consolidado, como espacio de desarrollo del conocimiento y el "saber"; y la ruptura que configuran el conocimiento de base experimental, social y artístico en sus distintas expresiones, las vinculaciones

12 García Canclini, Néstor. "Cultura y Comunicación: entre lo Global y lo Local". Ediciones de Periodismo y Comunicación Nro.9. UNLP. Octubre 1997. 
con el entorno socio productivo, la vitalidad expresiva y transformadora de los sujetos en ejercicio de sus derechos.

17 Facultades,

111 carreras de grado,

157 títulos posibles,

170 carreras de posgrado,

más de 500 cursos de posgrado,

\section{Colegios preuniversitarios,}

cerca de 137.000 alumnos (110.000 en carreras de grado, 22.000 en posgrado y 5.000 en Inicial, Primaria y Secundaria) en todos los niveles educativos, aproximadamente 12000 docentes,

3000 trabajadores administrativos y de apoyo docente,

154 Centros de Investigación y Desarrollo,

6.000 Investigadores,

una Red de Museos y Bibliotecas donde se destacan el Museo de Ciencias Naturales y la Biblioteca Pública,

un Observatorio Astronómico,

una Radio AM-FM,

un canal de televisión,

una Editorial,

el Albergue Universitario,

los 4 Comedores Universitarios (7000 almuerzos diarios),

cientos de dependencias y edificios, servicios sociales, de salud, alimentación, contención... son una síntesis enumerativa incompleta de lo que la UNLP contiene, brinda, es, propone, desarrolla...

\section{Los estudios en comunicación}

Vayan algunos datos para su caracterización.

- En relación con el número de carreras, de un total de 107 Instituciones universitarias ${ }^{13}$, de las cuales 40 son universidades estatales, 45 universidades privadas, 7 son institutos universitarios estatales, 12 son institutos universitarios privados, 1 universidad provincial 1 universidad

13 Fuente: Nómina de autoridades Universidades Nacionales 2002. Documento del Ministerio de Educación de la Nación. Página oficial del MEN. 
extranjera y 1 universidad internacional, en 47 de ellas se dictan carreras de Comunicación ${ }^{14}$. Es decir en un 60,2 \% de las universidades del país. De las cuales 23 corresponden a universidades públicas y 24 a universidades de gestión privada. La mayor parte de las carreras se dictan en la Capital Federal y en la provincia de Buenos Aires. Si se tiene en cuenta que de las universidades ubicadas en la provincia de Buenos Aires, la mayoría (8) se encuentran en un radio de no más de $100 \mathrm{~km}$ distantes de la Capital Federal, tenemos que el $40 \%$ de las carreras se concentra en esta región geográfica, (que además es la de mayor densidad poblacional).

- Es importante indicar también que alrededor del $50 \%$ de las carreras pertenecientes a universidades privadas se encuentran en la Capital Federal, mientras que en el caso de las universidades públicas éstas se distribuyen más ampliamente en todo el país.

En cuanto al ámbito institucional en que se desarrollan las carreras, resulta relevante identificar la diversidad existente en lo relativo al tipo de unidades académicas bajo cuya dependencia son incluidas, así como la presencia/ausencia de unidades académicas específicas.15 En relación a esto:

a) El $60 \%$ de las carreras de comunicación se dictan en unidades académicas no específicas. De este porcentaje, alrededor del $50 \%$ se desarrolla en unidades académicas de Humanidades y/o Ciencias Sociales. La mayoría de las carreras se ubica en facultades de Ciencias Sociales, Humanidades, Ciencias Políticas, Educación y Derecho o Ciencias Jurídicas.

b) Un porcentaje menor de las carreras, el $10 \%$ se desarrolla en unidades académicas especificas de comunicación pero integradas con otras disciplinas o carreras; siendo claramente mayor el número de universidades privadas que presentan esta estructura.

14 En este caso se incluye en el rubro "carreras de comunicación" a aquellas que contienen esta categoría en su denominación y sus orientaciones; a las carreras de periodismo y sus orientaciones y a las vinculadas a los medios de comunicación; incluyéndose licenciaturas, profesorados, carreras intermedias (tecnicaturas, bachilleratos universitarios, etc). No se han incluido en este primer momento carreras que corresponden predominantemente al diseño publicitario o al marketing, en las que la formación en comunicación es subsidiaria de estas áreas. Es importante indicar que no se incluyó específicamente el análisis las carreras dependientes de la Universidad del Cine, vinculadas con la comunicación audiovisual.

15 En cuanto a este aspecto se ha identificado la existencia de diferentes tipos de tales unidades de acuerdo con la estructura organizativa de cada universidad, registrándose los siguientes tipos: Departamentos, Departamentos académicos, Facultades, Escuelas e Institutos. 
c) Un $19 \%$ de las carreras se dicta finalmente en Unidades académicas específicas de Comunicación ${ }^{16}$, entre las que encontramos sólo una perteneciente a una Universidad pública (que posee una Facultad específica) mientras que las restantes unidades académicas pertenecen a universidades privadas.

Otro dato relevante remite a la variedad de titulaciones que se ofrecen, en tanto las mismas pueden dar cuenta de, al menos, dos aspectos centrales: por un lado una definición epistemológica y teórica respecto del campo académico (por ejemplo, la diferenciación que podría establecerse entre una carrera de "comunicación social", de "ciencias de la comunicación" o de "ciencias de la información"), así como a cierta definición de los campos laborales delimitados como incumbencias de los comunicadores (la comunicación institucional, el periodismo deportivo, la investigación en comunicación, la docencia, etc.). Si bien en cada una de las instituciones estas diferentes denominaciones pueden remitir a situaciones diversas de las que no es posible dar cuenta (momento de creación de la carrera, relación con otras ofertas en instituciones cercanas, tipo de dependencia institucional de la carrera, etc.); la descripción de este dato puede ofrecer un panorama global de los modos en que son designados estos dos aspectos, señalados anteriormente.

Es posible identificar que las carreras específicamente de Periodismo se desarrollan en mayor medida bajo la órbita de las universidades privadas, mientras que las que definen su campo como el de la Comunicación se ubican en mayor medida en universidades públicas. Éstas suelen incluir al Periodismo como una orientación en el campo más amplio de la Comunicación Social. Si sumamos los diversos tipos de denominaciones, de estas carreras de "comunicación", vemos que asciende a un $60 \%$ el porcentaje de las dependientes de universidades públicas. Respecto de las orientaciones de las carreras de Licenciatura, de las 47 universidades en que se dictan carreras de comunicación, 12 de ellas especifican orientaciones para las Licenciaturas en sus planes de estudio, las cuales no en todos los casos tienen mención en el titulo expedido. De éstas, 8 se ubican en universidades públicas y las restantes

16 Es decir que no dependen de otra estructura de nivel superior, a excepción de los respectivos rectorados de cada Universidad. 
en universidades privadas. En casi todos los casos las carreras presentan más de una orientación.

Respecto de la existencia de títulos intermedios o carreras cortas, el $60 \%$ de las universidades ofrecen estos títulos (28). De las cuales 16 corresponden a universidades privadas y 12 a universidades públicas. En cuanto a la variedad de los títulos, la misma asciende a un total de 22 tipos de titulaciones diferentes. El mayor número de ellos se compone de tecnicaturas en Comunicación / Comunicación Social y de tecnicaturas en Periodismo.

En cuanto a la duración de las carreras, el $70 \%$ de las mismas tiene una duración de 4 años y, un porcentaje inferior, de 5 años (mayoritariamente estas últimas pertenecen a universidades públicas). Las carreras y/o títulos intermedios tienen en su mayoría una duración de 3 años.

En relación con la presencia en las carreras el requerimiento de trabajos finales de grado, y de pasantías o prácticas profesionales, vemos que alrededor del $60 \%$ de las carreras de licenciatura incluyen como requisito la realización de un trabajo final de grado, que recibe diferentes denominaciones (Tesis, Tesina, Monografía, Trabajo Final, etc.). Es ostensiblemente menor el número de carreras que presentan formalmente la realización de pasantías profesionales, si bien la mayoría de las carreras incluyen la realización de estas prácticas en la formación, aun cuando se desarrollan al interior de asignaturas especificas.

Resultan especialmente importantes en este sentido la cuestión de la expansión -tanto de la matricula y de las carreras- así como la diversificación institucional de las mismas. Respecto de la cuestión relativa al financiamiento, las carreras de comunicación se encuentran atravesadas por esta expansión tanto de la matricula como del interés social por este campo en contraposición con una consolidación institucional relativamente reciente en el sistema de educación superior con las consecuentes dificultades para traducir este desarrollo en espacios institucionales propios, y en asignaciones presupuestarias acordes, en relación con otras disciplinas o áreas más antiguas o consolidadas. En este sentido, la presencia de espacios institucionales propios corresponde a universidades relativamente nuevas y del ámbito privado. 
En cuanto a los proyectos de formación de profesionales, en una primera aproximación, se observa la existencia de una serie de perfiles diferenciados de acuerdo con la valoración asignada a la emergencia de nuevas prácticas profesionales; a la consideración preferencial de un referente externo de articulación (el Estado, el Mercado, la sociedad civil); a las posibilidades de incorporación y utilización de nuevas tecnologías de la información, la presencia de tradiciones o tendencias marcadas por el desarrollo diferenciado de perfiles "profesionalistas", "cientificistas", "profesionales" o "científicos", etc.

La vinculación más general universidad-sociedad se expresa a su vez de manera compleja, en tanto se incluyen en este universo actores sociales, políticos, y económicos de muy diverso tipo y con una participación sumamente diferencial en la configuración del escenario histórico actual. Desde los multimedios globalizados hasta las acciones locales de planificación comunicacional para el desarrollo, pasando por el diseño de imagen y la investigación social en comunicación, el abanico de actores, intereses y funciones sociales implicados complejiza los espacios institucionales y los proyectos académicos que se desarrollan en estas carreras. Por último, en relación con los proyectos curriculares, además de los aspectos antes señalados se expresan tensiones relativas a los modos posibles de articulación entre diferentes campos del saber, no siempre lográndose "resoluciones" satisfactorias en la perspectiva misma de los actores implicados (grupos de gestión, docentes, alumnos). 


\section{Los escenarios del desafío}

"Las redes son formas muy antiguas de la actividad humana, pero actualmente dichas redes han cobrado nueva vida, al convertirse en redes de información. Impulsadas por Internet. Las redes tienen extraordinarias ventajas como herramientas organizativas debido a su flexibilidad y adaptabilidad. Características fundamentales para sobrevivir y prosperar en un entorno que cambia a toda velocidad." ${ }^{17}$ (Castells)

Tal como señala Castells, las redes no son propias de la era de Internet; pero han cobrado otras dimensiones en este nuevo escenario. ¿Qué se transforma y qué permanece en el arte al ser puesto en circulación en redes como Facebook, en blogs, en páginas webs? ¿cómo juega lo político? ¿qué sentidos de lo público entran en disputa? En este punto es importante señalar el rol de las tecnologías y sus usos desde un pensamiento complejo que no se reduce a la linealidad determinista de la causa- efecto, desde este marco de comprensión es que reconocemos que existen diferentes usos, apropiaciones y distintos accesos a estas nuevas tecnologías. "Es a ese desafío al que van dirigidos los esfuerzos por pensar la técnica como entorno tecnológico y ecosistema comunicativo, hoy socialmente tan estratégico como el ecosistema verde (...) es el entorno técnico el que se nos vuelve aceleradamente natural pues cada vez se hace más parte de nuestra corporeidad, de nuestra movilidad y de nuestra cognitividad" (Martín Barbero, Jesús en Morduchowicz (2008) $)^{18}$

Las tecnologías están atravesadas por relaciones de poder, que profundizan desigualdades y brechas $y$, por lo tanto, los accesos y usos que se hacen de ellas nunca son uniformes. Sin embargo, como comprendemos también que la mediatización no se limita a estar frente a los medios, consideramos que las tecnologías transforman las prácticas, las rutinas, los modos de producción de lo cultural incluso más allá de los accesos materiales. Transforman nuestra manera de percibir, mirar, transitar y organizar el mundo.

17 CASTELLS, Manuel (2001); La galaxia Internet. "Obertura: La red es el mensaje”; Plaza \& Janés Editores S.A; Barcelona. CASTELLS, op cit

18 MORDUCHOWICZ, Roxana (2008) (coord.) Los jóvenes y las pantallas; Ed. Gedisa, Barcelona; 2008. 
"Pero la influencia de Internet trasciende al número de usuarios, ya que lo que importa es la calidad de los usos de la red. Actualmente, las principales actividades económicas, sociales, políticas y culturales de todo el planeta se están estructurando por medio de Internet. De hecho, quedar al margen de dichas redes es la forma de exclusión más grave que se puede sufrir en nuestra economía y en nuestra cultura." Castells ${ }^{19}$.

Así, Internet se presenta como un espacio flexible y con la posibilidad de ser reconfigurado. Serán los usos y apropiaciones que se hagan de la Red los que transformen los sentidos de lo producido comunicacionalmente. Son los sujetos, los procesos y los contextos los que configuran a las tecnologías (y las tecnologías configuran, en un vínculo de ida y vuelta, a esos sujetos, contextos y procesos porque son ellas también creaciones sociales atravesadas por luchas y disputas de poder); por eso la importancia de reflexionar en torno a las transformaciones que se están produciendo. Es en este escenario, en este contexto en el que debemos redefinir el perfil de los profesionales de la comunicación

\section{Mayor crecimiento}

El cambio de enfoque de la Universidad hacia la sociedad en su conjunto, impulsado desde el Estado desde 2003, es verificable en una variedad de datos estadísticos, de los cuales, tal vez los más concluyentes, son los que muestran un aumento de un $28 \%$ de la población universitaria y un 54\% más de argentinos y argentinas que han concluido sus estudios universitarios en estos años que por esta y otras razones educativas y sociales.

En la última década, nuestro país inició un proceso de profundas transformaciones políticas, económicas y socioculturales. Los argentinos volvemos a transitar el camino de la Patria Grande y vivimos tiempos en los que quienes formamos parte del sistema universitario y científico argentino, somos interpelados respecto a nuestro rol y compromiso para con nuestro pueblo 20 . 
Entre el 2003 y el presente año, el sistema universitario nacional creció cuantitativa y cualitativamente: hecho evidenciado en la creación de nueve nuevas universidades y el crecimiento de la matrícula que, al día de hoy, ronda los 2 millones de estudiantes. Hoy en día, la inversión educativa representa el $6,4 \%$ del Producto Interno Bruto (PIB). En este período la Secretaría de Políticas Universitarias del Ministerio de Educación de la Nación pasó de contar con un presupuesto de 1800 millones de pesos para el año 2003 al presupuesto actual de 23.000 millones de pesos. La inversión en ciencia y tecnología es del 1,65\% del PIB. El presupuesto del CONICET creció 12 veces y este año cuenta con 2.889 millones de pesos a ser ejecutados. El $80 \%$ de los investigadores del sistema científico nacional se encuentran en universidades y son docentes de las mismas.

Además, la sanción y posterior implementación de la Ley de Servicios de Comunicación Audiovisuales ${ }^{21}$ inaugura en nuestro país un nuevo escenario cultural y político, que promueve una ampliación profunda del estado de derecho. Este nuevo escenario no sólo significa un recorte al poder monopólico de los grandes medios masivos de comunicación organizados empresas multimediales. Además, constituye una oportunidad histórica para que diferentes sectores de la sociedad accedan a espacios de producción de comunicación potenciando procesos democráticos de participación, inclusión, equidad y reconocimiento de las tradiciones, nutriendo desde la diversidad los sentidos que puede producir una sociedad cuando se mira y se piensa a sí misma.

21 La Ley 26.522 de Servicios de Comunicación Audiovisual y su Decreto reglamentario 1225/2010 es una ley que establece las pautas que rigen el funcionamiento de los medios radiales y televisivos en la República Argentina. Esta legislación fue promulgada el 10 de octubre de 2009 por la presidenta Cristina Fernández de Kirchner y reemplazó a la Ley de Radiodifusión 22.285, que había sido promulgada en 1980 por la dictadura cívico-militar autodenominada Proceso de Reorganización Nacional y se había mantenido vigente desde entonces. Desde la recuperación de la democracia el 10 de diciembre de 1983, existió un amplio consenso sobre la necesidad de derogar la norma de la dictadura y sancionar una nueva ley, en consonancia con las necesidades cívicas y participativas de la democracia. Los presidentes Raúl Alfonsín en 1988 y Fernando de la Rúa en 2001, presentaron sendos proyectos de ley, que no pudieron ser tratados, afectados por fuertes presiones por parte de los intereses involucrados. En agosto de 2009, la presidenta Cristina Fernández de Kirchner envió un proyecto de ley a la Cámara de Diputados para reemplazar la ley de radiodifusión, luego de haber sido debatido por un año, en 24 foros que se desarrollaron en distintos puntos del país, una propuesta de proyecto de ley basada en veintiún puntos presentados por la Coalición por una Radiodifusión Democrática en 2004.El proyecto de ley fue presentado en la Cámara de Diputados y aprobado por esta instancia luego de que se le realizaran más de 100 modificaciones, adquiriendo de esta manera la media sanción. En el Senado, fue aprobada por 44 votos a favor y 24 en contra. 
Se trata de potenciar la diversidad de discursos y perspectivas para multiplicar las voces, las opiniones y posiciones, las condiciones de producción y reconocimiento de los medios, los mensajes y las posibilidades de significar. Es decir, practicar libre y democráticamente la comunicación para romper con la uniformidad de la agenda temática y las posturas ideológicas legitimadas por el poder mediático concentrado.

No es posible imaginar una democracia real con monopolios mediáticos, ya que la multiplicidad de voces es imprescindible para implementar y hacer respetar los derechos para todos. En éste marco, la nueva ley considera a la comunicación en cualquiera de sus soportes como una actividad social de interés público, de carácter esencial para el desarrollo sociocultural de la población, por el que se exterioriza el derecho humano inalienable de expresar, recibir, difundir e investigar informaciones, ideas y opiniones sin ningún tipo de censura.

En este contexto de profundas transformaciones de la cultura, la sociedad y la política, la Universidad debe necesariamente volver a debatir sobre su misión político-educativa, y reconocer los nuevos trabajos a los que está siendo convocada para fortalecer cada uno de los procesos activados, sin perder su espíritu crítico y su capacidad de producir conocimiento original.

\section{Una vez más, son nuevas aquellas preguntas:}

- ¿Qué formar, desde qué idea formar?

- ¿Qué remite a la idea de proceso, de comprensión, construcción, historia y desarrollo?

- ¿Existe un paradigma de análisis y producción de la Comunicación Latinoamericano?

- ¿Qué idea sobre producción del conocimiento hegemoniza la comunicación del conocimiento, qué formas del conocimiento son excluidas? ¿Por qué?

- ¿Qué lugar ocupa la comunicación en el ámbito de las Ciencias Sociales? 
Las respuestas que surjan serán las claves para orientar las transformaciones necesarias en el campo de la comunicación. Observando a los sujetos y los contextos de desarrollo, con la certeza de que frente a la crisis de la conciencia de que en comunicación se juega de manera decisiva la suerte de lo público, la supervivencia de la sociedad civil y de la democracia.

\section{Instrumentos de las posibilidades}

Así como Eric Hobsbawm, en su Historia del siglo XX, plantea que éste no comenzó sino hasta 1914 y terminó al fin de la era soviética (aprox. 1989, con la eliminación del Muro que dividía Berlín), podemos decir que los 2000 en América Latina comenzaron el 2 de febrero de 1999, día en que Hugo Chávez Frías asumió la Presidencia de Venezuela y dio comienzo al tiempo llamado de la "Patria Grande" en el continente. Aquel hito fue completándose como un reguero eleccionario por toda América del Sur: el triunfo de Lula Da Silvia en Brasil en 2002, el Frente Amplio en Uruguay, en 2005; Evo Morales en Bolivia, en 2006; y Rafael Correa en Ecuador, en 2007, entre otros, y, en Argentina, a partir del 25 de mayo de 2003 empezó un período de producción sistemática, múltiple y multisectorial de políticas públicas restitutivas y constitutivas de derechos conculcados o nunca reconocidos.

Inicio este apartado con una enunciación sumaria de los hechos de la Era y lo completo con una selección comentada de alguno de los instrumentos de políticas públicas que sustentan materialmente lo posible y lo deseable para el desarrollo del "específico comunicacional" que me ocupa en esta tesis.

América Latina comenzaría a vivir un momento político y social inédito donde el viejo y fragmentado continente se volvió, en la lengua de la época, en una "región"; más aún, en una "región integrada"y soberana que comenzaría a abrir distintos canales y vías de articulación. Esa integración regional, por lo demás, que tiene un correlato fácilmente observable en el ámbito político y económico:

- En Mar del Plata en 2005, se realizó la IV Cumbre de las Américas, los mandatarios de la región rechazaron la pretensión norteamericana de 
imponer el proyecto del ALCA (Área de Libre Comercio de las Américas). "No nos vengan aquí a patotear", le dijo en esa Cumbre Néstor Kirchner al ex presidente George Bush", allí "se sentaron las bases de un proceso de integración entre naciones en desarrollo, y se ganó autonomía para relacionarse con todos los países y en particular los emergentes". La propuesta del ALCA impedía la reconstrucción del tejido industrial de la Argentina, e incluso iba a afectar el desarrollo del Mercosur, ya que con el libre comercio con Estados Unidos, el sur perdía sentido "Se ve que fue una decisión estratégica", sostuvo, y los que la tomamos estábamos convencidos. Y si bien había apoyo, mucha gente no veía la importancia de la decisión, pero si se hubiera seguido con el ALCA no podría haber existido la UNASUR y, por lo tanto, no se podría haber avanzado en la construcción de una visión de la América del Sur como un actor en desarrollo en el escenario internacional".

- UNASUR “Unión de Naciones Suramericanas": Un organismo internacional, conformado por los doce países de la región suramericana: La República Argentina, la República de Bolivia, la República Federativa del Brasil, la República de Colombia, la República de Chile, la República del Ecuador, la República Cooperativa de Guyana, la República del Paraguay, la República del Perú, la República de Suriname, la República Oriental del Uruguay y la República Bolivariana de Venezuela. Nuestro objetivo es construir un espacio de integración en lo cultural, económico, social y político, respetando la realidad de cada nación. Nuestro desafío es eliminar la desigualdad socio económica, lograr la inclusión social y la participación ciudadana, fortalecer la democracia y reducir las asimetrías, considerando la soberanía e independencia de los Estados. 
En Argentina, en el tiempo más reciente -para poder hacer síntesis-, de la cantidad de elementos novedosos ${ }^{22}$ que pueden dar cuenta de cómo se han transformado las condiciones actuales para la comunicación del conocimiento, la formación de comunicadores, y su desempeño profesional, hay dos que resultan centrales en la reflexión y el debate que se propone.

El primero es la Ley de Servicios de Comunicación Audiovisual, y sus organismos implementadores. El segundo es la provisión de tecnologías de última generación y relaciona con el fortalecimiento de políticas públicas destinadas al fomento de la producción de conocimiento científico y tecnológico en general (por caso el Programa Conectar Igualdad). Si bien pertenecen a campos diferentes, en nuestro caso estos dos elementos se conjugan y encuentran un punto en común clave para el debate propuesto: ambos ponen el énfasis en la acción. Se trata de procesos que han puesto en movimiento estructuras, actores y vínculos que durante muchos tiempo habían permanecido estables, e incluso algunos

22 Por ejemplo: Ley $\mathbf{2 6 . 0 7 5}$ de Financiamiento Educativo. La norma establece un aumento progresivo de la inversión destinada a la educación, hasta alcanzar en 2010 un total equivalente al $6 \%$ del Producto Bruto Interno.

Constitución de Arsat Creada por el Congreso el 5 de abril de 2006, la Empresa Argentina de Soluciones Satelitales es una sociedad concebida para promover la industria espacial, desarrollar satélites nacionales e intervenir en el terreno de las telecomunicaciones, explotando la posición orbital satelital que le corresponde a la Argentina y "tendrá como objetivo social" el diseño, desarrollo, lanzamiento y puesta en servicio de satélites geoestacionales en posiciones orbitales acordados ante la Unión Internacional de Telecomunicaciones (El 10 de junio de 2011 Argentina lanzó el satélite argentino SAC-D, de aplicaciones científicas, con un cohete Delta II, que lo colocó en una órbita alrededor de la Tierra a una altitud de $670 \mathrm{~km}$ (también conocido como Aquarius por su principal instrumento, es un satélite argentino de observación climática y oceanográfica, construido por INVAP. Contiene siete instrumentos para estudiar el medioambiente, y un paquete de demostración tecnológica. Fue lanzado desde una plataforma de la NASA. Tres años más tarde, el 16 de octubre de 2014, televisado en vivo para todo el país por la televisión pública y replicado miles de veces en redes sociales, el lanzamiento del satélite Arsat-1 fue todo un éxito científico tecnológico y comunicacional (esta vez desde una plataforma nacional).

Ministerio de Ciencia, Tecnología e Innovación Productiva. Creado el 10 de diciembre de 2007, es el primero en Latinoamérica que contempló a la innovación productiva asociada a la ciencia y la tecnología. Su misión es orientar la ciencia, la tecnología y la innovación al fortalecimiento de un nuevo modelo productivo que genere mayor inclusión social y mejore la competitividad de la economía Argentina, bajo el paradigma del conocimiento como eje del desarroIlo, diversificando la matriz productiva y atendiendo los problemas sociales. Desde el MCTelP se promueve el desarrollo de plataformas que permitan llevar a cabo innovaciones a partir de tecnologías de propósito general (biotecnología, nanotecnología, tecnologías de la información y las comunicaciones) que tienen en Argentina con la necesaria masa crítica de recursos humanos y de empresas en el sector productivo capaces de incorporar sus desarrollos. Estas plataformas a su vez se aplican a áreas verticales en las cuales hay problemas y oportunidades, estos sectores son la salud; la generación de energía renovable; el agregado de valor en la agroindustria; el desarrollo social y la atención a los problemas derivados del cambio climático. 
habían sido vaciados de contenido. Lo que se recupera es la sensación de movimiento, y con ellos, la acción emerge como la principal forma de canalizar todo aquello que ahora permiten y/o habilitan.

Vivimos años que podríamos denominar de "Estado Presente", de constante crecimiento de políticas y recursos destinados a garantizar los derechos de cada ciudadano. En lo específico que nos ocupa, el impulso de la educación en general y de la de Nivel Superior en particular que se sustancia en mejores condiciones de formación y el refuerzo de la producción de conocimiento a través de la investigación y la extensión, son algunos de los indicadores más relevantes. La revalorización de la formación universitaria en general, acerca a los estudiantes a una mirada de conjunto que los incluye; pensar la sociedad hoy conlleva a participar en la modificación de realidades adversas. La sanción de la Ley de Servicios de Comunicación Audiovisual (LSCA), la instrumentación de numerosos instrumentos ad hoc y la provisión de recursos tecnológicos universalmente, modifican sustancialmente el panorama de la comunicación como espacio laboral y desempeño profesional no sólo en relación con los medios de comunicación, sus estructuras de poder y propiedad, sino que también abre un nuevo escenario en el que emergen nuevos actores y se despliegan nuevas acciones vinculadas con proyectos de comunicación. Estas políticas generan nuevas posibilidades para volver a imaginar

Programa de Apoyo de Infraestructura Universitaria. En el último año de la presidencia de Néstor Kirchner se creó el "Programa de Apoyo para el Desarrollo de la Infraestructura Universitaria" que el entonces Ministro de Educación, Daniel Filmus, fundamentó en que se ponía "fin a años de desatención a la infraestructura universitaria por parte del Estado Nacional ya las universidades son imprescindibles como herramienta esencial en el crecimiento de un país más justo, más igualitario, más desarrollado, donde la base fundamental de la creación de la riqueza está vinculado al conocimiento, la ciencia y la tecnología". Este Programa comenzó con obras en las Universidades de Buenos Aires, La Plata, Misiones, Lanús, Cuyo, Litoral, Rosario y Luján; el Instituto Universitario Nacional de Arte (IUNA) y la Universidad Tecnológica Nacional (UTN), y a lo largo del período siguió por la totalidad de las instituciones del sistema estatal.

Ley 26.618 de Matrimonio Igualitario La República Argentina permite los matrimonios entre personas del mismo sexo desde el 15 de julio de 2010. De esta forma, el país se convirtió en el primero de América Latina en reconocer este derecho en todo su territorio nacional. Además, fue el décimo país en legalizar este tipo de unión a nivel mundial (El debate sobre la legislación autorizando el matrimonio entre personas del mismo sexo comenzó en la Argentina a partir de la campaña nacional por la igualdad jurídica lanzada por la Federación Argentina de Lesbianas, Gays, Bisexuales y Trans, bajo la consigna «Los mismos derechos, con los mismos nombres». Cabe destacar que en Argentina se utilizó la expresión matrimonio igualitario para hacer referencia a la reforma del Código Civil, porque se entendía en la sociedad que se trataba de la búsqueda de la igualdad entre sus habitantes. Fue desde aquí en la década de 2010 en donde también empezó a ser frecuentemente utilizado el término para referirse a la igualdad del matrimonio en otros países en donde se discutía o se discute, como Uruguay, Colombia, Chile o Brasil, masificándose el uso de la expresión para referirse al matrimonio homosexual. Unas 1300 parejas del mismo sexo contrajeron matrimonio durante los primeros seis meses de vigencia de la ley, y unas 2697 parejas en el primer año. Hasta diciembre de 2012 se han realizado 5839 uniones y para 2014 ya habían contraído matrimonio 9500 parejas). 
los sentidos de la transformación. Y en este desafío, la comunicación tiene un rol fundamental que torna necesario diseñar trayectos formativos a la luz de estas nuevas perspectivas, de las condiciones estructurales y materiales, de esta nueva posibilidad de comunicación que requiere de nuevos comunicadores con capacidad de imaginar nuevos proyectos $y$ de este modo, ampliar el horizonte de expectativas.

\section{Ley de Servicios de Comunicación Audiovisual}

El lento proceso que concluyó en la sanación de la ley de Servicios de Comunicación Audiovisual (LSCA) inició 27 de agosto de 2004. En esa oportunidad, se reunieron más de trescientas organizaciones comunitarias, sociales, gremiales, pymes y de derechos humanos que acordaron veintiún puntos para la democratización de los medios, claves para en el marco de la Coalición por una Radiodifusión Democrática. La Ley de Servicios de Comunicación Audiovisual (LSCA 26.522) fue elevada al Congreso de la Nación donde la Cámara de Diputados la aprobó, el 17 de septiembre de 2009, con 147 votos a favor y apenas 4 en contra y una abstención. El 10 de octubre el Senado, con 44 votos a favor y 24 en contra sancionó la LSCA Sancionada y Promulgada.

Se inaugura en nuestro país un nuevo escenario cultural y político, que promueve una ampliación profunda del estado de derecho y un recorte al poder monopólico de los grandes medios masivos de comu-

Ley 26.743 de Identidad de Género. Promulgada el 10 Mayo 2012, le otorga a toda persona el derecho a adecuar toda su documentación al sexo, imagen y nombre de pila que desee, sin necesidad de recurrir a la Justicia. Ordena que todos los tratamientos médicos de adecuación a la expresión de género sean incluidos en el Programa Médico Obligatorio, lo que garantiza una cobertura de las prácticas en todo el sistema de salud, tanto público como privado. Es la única ley de identidad de género del mundo que, conforme las tendencias en la materia, no patologiza la condición trans (A dos años de su sanción, cerca de 4000 personas trans accedieron ya al reconocimiento de su identidad por vía administrativa. Esto es, tienen su nuevo DNI con el nombre que las representa desde hace años. Además, según los activistas por los derechos del colectivo, se registraron algunos avances en materia de educación y empleo, mientras el acceso a la salud integral sigue siendo el aspecto que más retraso presenta en todo el país).

Ley $\mathbf{2 6 . 7 7 4}$ de Voto optativo para los jóvenes de entre 16 y 18 años A partir del 31 de Octubre de 2012 los jóvenes mayores de 16 años gozarán de todos los derechos políticos conforme a la Constitución y a las leyes de la República. El proyecto modificó siete leyes nacionales, entre ellas el Código Nacional Electoral (CNE), el Registro Nacional de Electores, la Ley de Ciudadanía y Naturalización y la ley que establece las primarias abiertas simultáneas y obligatorias (EI reconocimiento de la calidad de electores de este vasto sector social, posiciona a la Argentina, una vez más, entre los países que más han avanzado en materia de inclusión electoral, junto con otros Estados de la región que ya han ampliado la base de participación electoral, como Brasil, Nicaragua y Ecuador -que fijan la edad mínima para sufragar a los 16 años- o Chile -que la establece a los 17-. El "voto joven" debutó con un 80\% de presentismo y opiniones divididas, Unos 480.000 chicos de 16 y 17 años, de un total de 600.000, eligieron legisladores por primera vez). 
nicación organizados en empresas multimediales. Además, constituye una oportunidad histórica para que diferentes sectores de la sociedad accedan a espacios de producción de comunicación potenciando procesos democráticos de participación, inclusión, equidad y reconocimiento de las tradiciones, nutriendo desde la diversidad los sentidos que puede producir una sociedad cuando se mira y se piensa a sí misma. Se trata de potenciar la diversidad de discursos y perspectivas para multiplicar las voces, las opiniones y posiciones, las condiciones de producción y reconocimiento de los medios, los mensajes y las posibilidades de significar. Es decir, practicar libre y democráticamente la comunicación para romper con la uniformidad de la agenda temática y las posturas ideológicas legitimadas por el poder mediático concentrado. No es posible imaginar una democracia real con monopolios mediáticos, ya que la multiplicidad de voces es imprescindible para implementar y hacer respetar los derechos para todos.

Programa Raíces. El Programa ofrece la "repatriación" de científicos desde el extranjero, mediante el subsidio de su traslado, radicación doméstica más la profesional. Raíces refiere un importante cambio de tendencia: de expulsiva a un tiempo de recuperación. Elevado a Ley por el Congreso de la Nación, es una política de Estado (Al mes de noviembre de 2014 se confirman 1120 Científicos repatriados a través del Programa Raíces).

Programa PROG.R.ES.AR. El “Programa de Respaldo a Estudiantes de Argentina”, creado el 22 de enero de 2014, propone capacitar a los jóvenes entre 18 y 24 años de edad inclusive con el fin de completar la escolaridad obligatoria, iniciar o facilitar la continuidad de una educación superior y realizar experiencias de formación y/o prácticas calificantes en ambientes de trabajo. Es un nuevo derecho para los que no trabajan, trabajan informalmente o tienen una remuneración menor al salario mínimo vital y móvil -y su grupo familiar está en iguales condiciones-.

Plan Nacional de Telecomunicaciones Argentina Conectada. Creado en 2010, es una estrategia integral para mejorar la comunicación diaria de todos los habitantes, involucrando a provincias, municipios, sindicatos, pymes, cooperativas y universidades, con el objetivo de establecer una plataforma digital de infraestructura y servicios que brinde soluciones de conectividad al 97 por ciento de las localidades del país y previendo la conexión satelital al 3 por ciento restante para 2015.

Red Federal de Integración Digital. Es el espacio virtual para el proceso de participación, acceso e integración de las personas involucradas e interesadas en las Políticas Públicas de Inclusión y Accesibilidad Digital.

Ley $\mathbf{2 6 . 6 9 2}$ del Régimen de Promoción de la Industria del Software. Tiene como objetivo fortalecer a un sector de la economía considerado estratégico para el desarrollo nacional mediante el incremento del empleo calificado, las exportaciones, las actividades de investigación y desarrollo y los estándares de calidad. Las empresas que aplican al Registro de Productores de Software y Servicios Informáticos gozan de estabilidad fiscal, perciben un bono de crédito fiscal aplicable a la cancelación de impuestos nacionales, y pueden efectuar una desgravación sobre el Impuesto a las Ganancias.

Programa Fútbol para Todos. El 25 Agosto 2009 se presenta el "Programa Fútbol para Todos", que transmite en forma gratuita, en vivo y a través de los sistemas de televisión abierta los torneos oficiales de fútbol organizados por la Asociación del Fútbol Argentino a todo el territorio del país.

Sistema Argentino de Televisión Digital. Llamado TDA, es una política pública que garantiza el acceso universal a la televisión de aire de modo gratuito y en todo el país, promoviendo la diversidad cultural, la democratización de la información y mejorando la calidad de audio y video. 


\section{Alcances de la Ley:}

- Garantiza la libertad de expresión

- Reconoce y le otorga participación a las organizaciones no gubernamentales.

- Establece mecanismos para limitar la concentración en la propiedad de los medios. Imposibilita la propiedad cruzada en el sector audiovisual. Según el art. 45, una misma empresa o persona puede poseer hasta 10 licencias cuando sea radio, televisión abierta o televisión por suscripción. Y hasta 24 licencias cuando se trate de licencias para la explotación de servicios de radiodifusión por suscripción con vínculo físico (cable) en diferentes localizaciones. La Ley deja en claro que la multiplicidad de licencias no podrá significar prestar servicios a más del 35\% de los habitantes o abonados.

- Impide a las telefónicas obtener licencias de medios. Es decir, limita la participación en el sistema de medios de un actor muy poderoso reduciendo el riesgo de monopolización.

- Reconoce al menos tres tipos de prestadores: estatales, privados con fines de lucro y privados no comerciales. Por vez primera en la historia de la radiodifusión Argentina se le otorga importancia a las Universidades y los pueblos originarios.

- Da lugar a la conformación del Consejo Federal de Comunicación Audiovisual, donde debieran participar distintos actores sociales: empresas, representantes provinciales, pueblos originarios, sindicatos, entre otros.

- Reduce la injerencia del poder Ejecutivo en la toma de decisiones y nombra un órgano de aplicación para la misma (AFSCA, Autoridad Federal de Servicios de Comunicación Audiovisual) que deberá ser autónomo y con representación para la minorías políticas parlamentarias.

- Reconoce y revaloriza la presencia de pequeños canales de televisión y radios en distintas localidades del interior del país.

- Exige cuotas de producción local, promoviendo el federalismo en un país donde el centralismo de Buenos Aires ha dominado la política de medios, entre otras políticas. (art. 65: producción nacional 60\%, producción propia $30 \%$ e independiente $10 \%)$ 
- Se asignaran licencias sólo a partir de concursos públicos, abiertos y permanentes. (art. 32)

- Estable como plazo para la adecuación a la normativa un (1) año. Esto significa que los propietarios de medios que no se ajusten a la letra de la ley deberán desinvertir. Aspecto que ha generado nuevos y enormes debates.

- Crea nuevos figuras de autoridad: art 17: Consejo Asesor de la Comunicación Audiovisual y la infancia. Art 18: crea en el ámbito del Congreso Nacional, la comisión Bicameral de Promoción y Seguimiento de la Comunicación Audiovisual. Art. 19: crea la Defensoría del Público de Servicios de Comunicación Audiovisual. Art. 119 crea Radio y Televisión Argentina Sociedad del Estado, que tiene a su cargo la explotación de radio y televisión del Estado nacional.

\section{Proceso Reglamentación}

Con la sanción de la LSCA el Congreso Nacional reemplazó el decreto-ley 22.285 sancionado en 1980, alcanza los servicios de radio y televisión abierta por cable y satelital. Regula por tipos de servicios y no por tecnología, sino cada vez que cambie la tecnología tendría que cambiar la Ley. Además, presenta elementos destacables para el fortalecimiento de la comunicación democrática. El principal y por un tiempo inédito en el mundo, es lo expresado por el artículo 89 sobre la reserva en la administración del espectro radioeléctrico, "donde el 33\% de las localizaciones radioeléctricas planificadas, en todas las bandas de radiodifusión sonora y de televisión terrestres, en todas las áreas de cobertura" se reservaran para organizaciones sin fines de lucro. Además, por vez primera en la historia de la radiodifusión argentina, los pueblos originarios tienen derecho a acceder a frecuencias en AM, FM y Televisión.

Una vez sancionada la Ley por el Congreso Nacional, comienza una nueva instancia: la discusión por la reglamentación de la misma. Se inicia, entonces, un nuevo periodo de toma de posiciones a favor y en contra. El marco principal vinculado a la reglamentación de la LSCA, lo da la intervención del diputado nacional Enrique Thomas quien interpone una medida cautelar para suspender la aplicación de la misma Tal decisión fue ratificada por la Cámara Federal de Apelaciones. El 15 de junio de 
2010 la Corte Suprema de Justicia de la Nación anuló la medida cautelar dictada en Mendoza, que suspendió la aplicación de la nueva ley. La jueza de la provincia de Mendoza, Olga Pura de Arrabal, da lugar a dicha suspensión y su intervención es avalada por la Cámara de Apelaciones en segunda instancia de la misma provincia. "El fallo mendocino se convirtió en un elemento clave de este proceso y de esta discusión, por los efectos institucionales de la medida, por las precariedades del fallo en términos legales, por la discutible legitimidad de una medida cautelar que suspende la aplicación de una norma solo a partir de elementos del proceso de sanción y sin comentar ni una línea del texto normativo, por las denuncias sobre la actuación de los camaristas, por la apelación del gobierno nacional y la llegada de la situación a la Corte Suprema de Justicia de la Nación y por la propia decisión del máximo tribunal, que declaró -en su fallo del 15 de junio de 2010 y por unanimidad- la incompetencia de cualquier juez y de cualquier tribunal para suspender una norma de aplicación nacional mediante una medida cautelar"23

La intervención de la Corte Suprema le otorga validez a la propia Ley y fortalece el proceso de reglamentación, reconociéndola como norma legítima y necesaria para la implementación de un sistema de medios más democrático donde la libertad de expresión y el derecho a la información son pilares fundamentales.

La coyuntura y la disputa de diversos sectores de poder se cristalizan en distintas medidas en contra de la implementación de la LSCA. Dichas medidas no reconocen el proceso participativo que da origen a la discusión de la nueva norma, donde sobresalen los aportes de la Coalición por una Radiodifusión Democrática. La LSCA recoge los veintiún puntos recomendados por dicha Coalición para la nueva normativa.

\section{Balance}

A cinco años de la sanción de La Ley de Servicios de Comunicación Audiovisual, confirmamos que es una norma de vanguardia, que entiende la comunicación como un derecho humano equivalente a la libertad de expresión, y que promueve la democratización de las voces prestadoras de servicios. Su modo de concebir la comunicación es inclusivo,

23 MARINO, Santiago "Argentina: El Proceso de Regulación Democrática" en Proceso Progresismo y políticas de comunicación: manos a la obra / Gustavo Gómez Germano. [et.al.];edición literaria a cargo de Alberto Koschützke y Elisabet Gerber. - 1a. ed. - Buenos Aires: Fundación Friedrich Ebert, 2011. 
plural, y fuertemente antimonopólico y anticorporativo. La normativa es ágil y moderna: genera un marco para regular un sector por demás dinámico de la economía, sujeto a los continuos cambios e innovaciones tecnológicas del área audiovisual.

Se presentan posiciones críticas acerca de la implementación de la Ley: "tras el anuncio de la adecuación de oficio del grupo Clarín, las probabilidades de una nueva judicialización habilitará nuevamente este argumento. Todos suponemos que esto se va a judicializar, que vamos a tener nuevamente un escenario de cautelares, demoras en la justicia. El grupo Clarín hará algún tipo de presentación judicial y tiene el antecedente que el fallo de la Corte Suprema de Justicia indicaba que no debía haber una aplicación discriminatoria de la ley y por lo tanto es probable que algún tipo de cautelar obtenga en relación a la adecuación de oficio por parte de la AFSCA. Si no lo obtiene se procederá a la adecuación pero hay elementos que nos permitirían pensar que ocurrirá lo otro. En este sentido se volvería a trabar todo el proceso de adecuación. AFSCA volvería a argumentar, como lo hizo en 2012-2013, que si no le puede aplicar la ley al grupo Clarín no la aplicará para el resto de los grupos y seguramente entraremos en una nueva fase de demora en la aplicación completa de la ley. Peor aún, hay una voluntad política para no avanzar en determinadas líneas que no es tan fuerte como la voluntad política de atacar a Clarín todo el tiempo"24.

Asimismo, se pueden observar ciertas consecuencias directas o indirectas de la aplicación de la Ley de Servicios de Comunicación Audiovisual:

- Garantizar el derecho a la información.

- Evitar la formación de monopolios y diversificar los prestadores.

- Asegurar frecuencias y espacios audiovisuales que garanticen la pluralidad.

- Fomentar contenidos diversos.

- -ncentivar la producción local.

- Abrir y poner en circulación un registro público de prestadores 
- 1200 autorizaciones y licencias a radio AM y FM y televisión abierta y paga.

- Más de 698 licencias de radio AM y FM al sector privado.

- Primeras 27 licencias para radios de baja potencia en zonas de alta vulnerabilidad social (art. 49).

- Primeros 42 reconocimientos a canales de televisión de baja potencia.

- 36 reservas de televisión a estados provinciales.

- 1132 reservas de frecuencias de radios para municipios.

- Llamado a concurso para 1373 frecuencias de radio en todo el país.

- 59 autorizaciones de medios a municipios y gobernaciones.

- 200 radios comunitarias con reconocimiento.

- 44 licencias para radios pertenecientes a la Iglesia Católica.

- Se realizaron en el primer semestre llamados a concurso de 41 frecuencias en Jujuy, otras 91 en Formosa y 179 en Córdoba.

- Se implementan capacitaciones previas a cada llamado a concurso para que los oferentes puedan resolver con sencillez los requisitos formales.

- Se organizaron los próximos llamados para Chaco, La Rioja, San Juan, San Luis, Catamarca, La Pampa, Neuquén, Santiago del Estero, Tucumán, Río Negro, Chubut y Tierra del Fuego.

- Se pusieron a disposición en junio 593 frecuencias, vacantes de concursos anteriores de Chaco, Chubut, La Pampa, La Rioja, Mendoza, Neuquén, Salta, San Juan, San Luis, Santiago del Estero, Tierra del Fuego y Tucumán.

- 252 medios (radio y televisión) ya autorizados a escuelas primarias, institutos educativos y universidades.

- Fueron autorizados 38 radios y 1 canal de pueblos originarios.

- Cientos de capacitaciones en todo el país a trabajadores, periodistas y licenciatarios de medios de comunicación audiovisual.

- Subsidios y créditos mediante convenios de AFSCA con el Fondo Nacional de las Artes, Banco Nación y el Ministerio de Industria.

- Puesta en marcha del Fondo de Fomento Concursable para Medios de Comunicación Audiovisual, FOMECA. 
- Por medio del FOMECA se otorgaron 4,5 millones de pesos para financiar 23 proyectos de equipamiento e infraestructura y 60 de producción audiovisual

- FOMECA 2014 destina 15 millones de pesos a financiar equipamientos para radios, Pueblos Originarios, y producciones de radio y TV de medios sin fines de lucro.

- Todas las empresas excedidas de los límites establecidos en la LSCA presentaron sus planes de adecuación ante AFSCA.

- Licencias para 116 cable operadoras PyMES y cooperativas que producen3000 horas diarias de programación

\section{Políticas de Implementación}

Para concretar y garantizar la correcta implementación de la LSCA, tal como se indica en la misma se adaptaron y/o crearon diversos organismos e instituciones:

\section{Consejo Asesor de la Comunicación Audiovisual y la Infancia}

El principal objetivo es asesorar a la Autoridad Federal de Servicios de Comunicación Audiovisual en materia de contenidos para la niñez. El Ministerio de Desarrollo Social de la Nación forma parte del Consejo por medio de la Secretaría Nacional de Niñez, Adolescencia y Familia, organismo público encargado de promover y garantizar los derechos de niños y niñas a nivel nacional. Participan también los gobiernos provinciales, el de la Ciudad Autónoma de Buenos aires, el Ministerio de Educación de la Nación, gremios docentes y organizaciones de la sociedad civil.

\section{Defensoría del Público de Servicios de Comunicación Audiovisual}

Es la institución creada para que los oyentes y televidentes puedan presentar sus consultas, reclamos y denuncias de manera simple y gratuita. Para garantizar los derechos a que en la radio y la televisión no se promuevan o se inciten tratos discriminatorios, a que no se menoscabe la dignidad humana, a que no haya violencia simbólica contra las mujeres ni comportamientos perjudiciales para el ambiente o para la salud de las personas y la integridad de niñas, niños y adolescentes. El fundamento de la Defensoría se basa en que la ley considera que los medios de comu- 
nicación son de interés público, que la información es un derecho, no un negocio, y que las trabajadoras y trabajadores de la radio y la televisión tienen responsabilidad social. El derecho a la comunicación implica dar y recibir información, ideas y opiniones, a buscarlas y difundirlas y es un derecho es inalienable. .

\section{Radio y Televisión Argentina Sociedad del Estado ${ }^{25}$}

Es una empresa pública (Sociedad del Estado) argentina que administra los medios de comunicación estatales. Tiene a su cargo la operación de la TV Pública, LRA Radio Nacional, FM Nacional Rock y Radiodifusión Argentina al Exterior (RAE), que depende directamente de la anterior.

\section{TV Digital}

La Televisión Digital Abierta (TDA) política de integración digital impulsada por el Ministerio de Planificación Federal Inversión Pública y Servicios, es una plataforma de TV que utiliza la más moderna tecnología digital para transmitir en alta calidad de imagen y sonido de manera gratuita, permitiendo además ofrecer adicionalmente otros servicios interactivos. Para lograr que más del $82 \%$ de la población nacional disfrute de este servicio, se instalaron 82 Estaciones Digitales de Transmisión (EDT) en diferentes puntos del país que emiten la señal de la TDA.

Existen dos formas de transmitir la Televisión Digital Abierta: la terrestre y la satelital.

Hoy estamos atravesando un proceso de transición que implica el paso de la televisión analógica a la Televisión Digital. Este proceso se desarrollará durante varios años hasta que ocurra el "apagón analógico", el cual implicará que sólo se transmita señal en forma digital. El mencionado "apagón analógico" trae aparejado un profundo cambio cultural y tecnológico, es por eso que con el objetivo de democratizar el acceso a las nuevas tecnologías se impulsa el Plan Operativo de Acceso "Mi TV Digital", para garantizar la igualdad de posibilidades de acceso a la TDA. 


\section{Contenidos}

En el marco de las políticas integración impulsadas por el Estado Nacional, la aprobación de la Ley de Servicios de Comunicación Audiovisual (ley 26.522) y la implementación del Sistema Argentino de TV Digital Terrestre, crearon las condiciones para que la emisión de señales en alta definición (HD) llegue a la televisión dentro de un proceso de democratización con nuevas voces, actores fundamentales de un nuevo escenario comunicacional. Esta política forja una nueva televisión que permite superar, de una vez y para siempre, el alejamiento del público de su propio escenario y construir una nueva democracia cultural y participativa, que incluye a todos los habitantes del país A partir de la suscripción de convenios entre el Ministerio de Planificación Federal, Inversión Pública y Servicios, la Universidad Nacional de San Martín (UNSAM), el Instituto Nacional de Cine y Artes Audiovisuales (INCAA) y el Consejo Interuniversitario Nacional (CIN), se llevan adelante concursos de alcance federal para la nueva Televisión Digital Abierta. Se trata de hacer realidad un derecho fundamental: que todos los sectores sociales de nuestro país puedan comunicar, compartir y recrear sus propias historias. Es necesario redoblar los esfuerzos en fomentar la producción de contenidos federales de alta calidad, en las diversas regiones del país para lograr una televisión pública e inclusiva, se planifican y producen según estas señales:

- ACUA Mayor: "La experiencia cuenta": Es un espacio audiovisual en donde los protagonistas son los adultos mayores: tiene como objetivos fundamentales desmitificar los prejuicios sobre la vejez y promover el envejecimiento activo y positivo.

- ACUA Federal: "Argentinos cuentan Argentina": Nace con el objetivo de ser medio y mensaje de todos los ciudadanos y ciudadanas. Invita a ver, a hacer televisión. Otra televisión: democrática, inclusiva, plural. Pretende, explorar colectivamente las identidades nacionales y sus formas de expresarse

- BACUA: "Banco Audiovisual de Contenidos Universales Argentino" es una fuente de contenidos audiovisuales digitales disponibles tanto para los nuevos espacios de emisión como para los ya existentes, de libre acceso y de distribución gratuita. La renovación tecnológica que 
representa la TDA supone el desafío y la necesidad de ampliar y federalizar la oferta de contenidos audiovisuales. Productores independientes de todas las provincias, organismos gubernamentales y no gubernamentales, universidades, agrupaciones sociales, culturales y señales que cuenten con producciones propias, pueden ceder sus contenidos de manera gratuita al BACUA para ser distribuidos a los canales de televisión de todo el país.

- CDA "Contenidos Digitales Abiertos": Es una plataforma que integra las políticas de promoción de contenidos audiovisuales digitales que Ileva adelante el Estado Nacional. Surge a partir de la necesidad de difundir contenidos de producción nacional, busca que su dinámica sea lo suficientemente ágil como para cautivar a los espectadores, actualizando e implementando nuevas tecnologías.

- Panorama Argentino: Un programa de contenido netamente federal, denominado emitido en diferentes canales del país. Con formato de informes de noticias, el envío es una vez por semana con una hora de duración por los canales públicos y cooperativos asociados a la red del CFTVP $^{26}$.

- Polos: El Programa Polos Audiovisuales Tecnológicos. A partir de la división del país en nueve regiones (Polos), se constituye un sistema federal en red donde las Universidades Nacionales nuclean a los actores del sector audiovisual televisivo de cada comunidad para conformar Nodos Audiovisuales son sistemas productivos locales integrados por cooperativas, organizaciones sociales afines al sector audiovisual, PYMES, productores independientes, televisoras y organismos públicos locales. Las Universidades Nacionales y los actores audiovisuales del medio local trabajan juntos para desarrollar y consolidar la producción televisiva de las distintas regiones de nuestro país ${ }^{27}$. 


\section{Multiplicar Palabras/Imágenes}

\section{Antes de la LSCA}

\section{Canal Encuentro 28}

Primer canal de televisión del Ministerio de Educación de la República Argentina. Funciona en el marco de Educ.ar Sociedad del Estado.

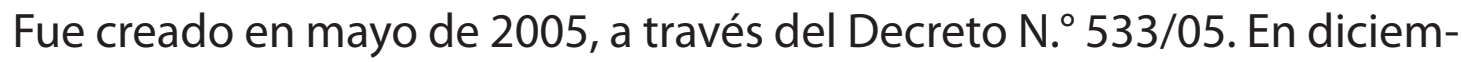
bre de 2006, fue reconocido por la Ley de Educación Nacional N.º 26.206. Comenzó su transmisión el 5 de marzo de 2007.

Si bien se dirige a todo el público, esta señal constituye una importante herramienta para la comunidad educativa. Es un canal federal que incluye contenidos de todas las regiones de la Argentina, además de producciones adquiridas de prestigiosas productoras de América Latina y del mundo. Se trata de un servicio público de comunicación y no posee publicidad. Alcanza a más de seis millones de hogares de todo el país, durante las veinticuatro horas, a través de una red de mil cuatrocientos cableoperadores; mediante franjas horarias en distintos canales locales de televisión abierta; en la Televisión Pública (Canal 7) de aire de Argentina, de alcance nacional; a través de la Televisión Digital Terrestre (TDA). Además puede verse en vivo a través de Internet, posibilitando el acceso a los contenidos por parte de los países de Latinoamérica y el mundo.

Desde el inicio del proyecto, Encuentro trabaja con la firme convicción de que el Estado puede desarrollar una nueva televisión educativa y cultural. Los objetivos de Canal Encuentro son: Contribuir a la equidad en el acceso al conocimiento para todos los habitantes de la Argentina y los países de la región, independientemente de su lugar de residencia o condición social; brindar a las escuelas contenidos televisivos y multimedia que aporten a la calidad de la educación de la Argentina; ofrecer herramientas innovadoras para facilitar y mejorar los procesos de enseñanza y aprendizaje en el marco de los desafíos actuales de la educación para la construcción colectiva de una sociedad más justa.

28 Premios: Entre los numerosos premios que recibió la programación y producción de Encuentro, destacan los premios Martín Fierro a las series Mundo Bayer, Encuentro en el estudio, Continuará..., premios TATO a Encuentro en el estudio y a Lalo Mir como su conductor y el segundo premio de ficción del Prix Jeunesse lberoamericano a Presentes y el tercer premio de no ficción a Vivir juntos. 
Como medio de comunicación de la TV pública, trabaja en la construcción de ciudadanía, da cuenta de los intereses comunes, muestra imágenes de lo que somos y expresa la diversidad existente. Considera a la audiencia como ciudadanas y ciudadanos sujetos de derecho. Es una herramienta pedagógica que aporta a la función social de la enseñanza, tanto para el sistema educativo como para la sociedad en su conjunto. Su programación se orienta a la construcción de una audiencia reflexiva y crítica

\section{Encuentro en la Web ${ }^{29}$}

Complementa la emisión televisiva y vincula la transmisión con las nuevas tecnologías de la información y la comunicación para potenciar ambos medios y generar un espacio de convergencia30. También tiene cuentas en Facebook, Twitter y YouTube.

Encuentro realizó propuestas especiales como ciclos Twitcam con presentadores de las series y personalidades de la cultura; Belgrano, tu película, en la que grupos de alumnos de todo el país recrearon la película Belgrano, escena por escena, con la ayuda de tutoriales; el documental interactivo 30 años de democracia, con testimonios sobre los acontecimientos más relevantes del período; Busco y Encuentro, una herramienta de búsqueda ubicada en la web de Encuentro que realiza las búsquedas a partir de los más de 800 subtítulos de toda la programación; y las guías didácticas Encuentro en el aula, con recomendaciones para los docentes para aplicar los contenidos de las series del canal en el aula ${ }^{31}$.

29 El sitio -www.encuentro.gov.ar- posee información sobre programación, recursos educativos multimedia e interactivos, noticias y novedades institucionales, propuestas audiovisuales especialmente pensadas para su consumo on-line y acceso a otros sitios de Educ.ar S. E.

30 Durante 2013 el tráfico mensual del sitio fue de 200 mil personas con una duración media de 3.50 minutos, recibió un total de 2.627.507 visitas.

31 En Facebook ha logrado más de 580 mil seguidores, 90 mil usuarios activos por mes y un promedio de comentarios por semana de 1.300. El Facebook de Encuentro sus seguidores son principalmente de Argentina aunque también de América Latina, Estados Unidos, España y, en menor cantidad, de Asia y África. En Twitter, 107 mil personas siguen a Encuentro con 500 menciones promedio por semana y 150 retwits por semana. En YouTube, tiene 50 mil suscriptores y más de 11 millones de reproducciones. Además, utilizando la interactividad de las redes sociales. 
Es el primer canal infantil del Ministerio de Educación de la República Argentina. Inició sus trasmisiones regulares de prueba el 9 de septiembre de 2010, a través de la señal de Televisión Digital Terrestre en el canal 22 de UHF, y a través del satélite AMC-633. Dirigido a chicos de 2 a 12 años, e incluye microprogramas, documentales y dibujos animados. La propuesta consiste en una señal infantil con contenidos de alta calidad orientados a educar y a entretener, abierto a la cultura de todos los sectores de Argentina y a distintas expresiones del globo.

\section{Después de la LSCA}

A partir de enero de 2014, Pakapaka fue incluido en la grilla del paquete básico de Cablevisión, luego de reiterados pedidos de la aplicación del artículo 65 de la Ley de Servicios de Comunicación Audiovisual que establecía que los prestadores de TV paga debían incluir en su grilla las señales de Radio Televisión Argentina Sociedad del Estado, todas las emisoras y señales públicas del Estado nacional y todas aquellas en las que el Estado tenga participación. De esta forma el canal cuenta con más de 10 millones de abonados.

Los principales objetivos de Pakapaka son: Concebir a los niños y niñas como ciudadanos, sujetos de derechos y productores de cultura; que los chicos y chicas sean protagonistas en la pantalla y en la definición de contenidos; reflejar en la programación las múltiples experiencias de ser niño/a en nuestro país. Considerar la infancia como un desafío complejo; constituir un lugar de diálogo con la escuela y con todas las instancias que hacen a la subjetividad de los chicos y las chicas, conformar un espacio lúdico e imaginativo.

32 La voz pakapaka en idioma quechua significa "escondite, juego de niños", referido al juego de escondidas

33 El canal PAKA PAKA fue lanzado por la Presidenta de la Nación, Cristina Fernández de Kirchner, junto al Ministro de Educación, Profesor Alberto Sileoni, en un acto realizado en la Quinta Presidencial de Olivos el 17 de septiembre de 2010 La voz pakapaka en idioma quechua significa "escondite, juego de niños", referido al juego de escondidas 


\section{TaTeTi34: un mundo de diversión sin igual}

Un canal dedicado a la audiencia infantil las 24 horas al día, con una programación que capta al público infantil desde los 2 a los 13 años Ta Te Ti es operado por el Ministerio de Educación de Argentina con apoyo del Ministerio de Desarrollo Social y de la Secretaría de Deportes; y es una de las señales que se distribuyen a través del Sistema de Televisión Digital Terrestre en Argentina ('TDA').Horas de producción local original, en divertidos formatos, encuestas, entrevistas, cortos infantiles y mucha diversión. Capacidad de producción en cualquier país de Latinoamérica con formatos flexibles de impacto 360 como concursos, viajes por la naturaleza, sitios de interés, deportes, cultura y tecnología.

\section{DEPORTV 35}

El canal de deportes del Estado Nacional organizado por el Ministerio de Educación de Argentina con apoyo del Ministerio de Desarrollo Social y de la Secretaría de Deportes; y es una de las señales que se distribuyen a través del Sistema de Televisión Digital Terrestre Argentina. A partir del 3 de enero de 2014 empezó a transmitir en alta definición. La señal llega al $85 \%$ de los hogares argentinos a través de la TDA y a más de 200 mil abonados al cable.

La señal cubrió y transmitió los Juegos Olímpicos de Londres 2012, así como las eliminatorias y la Copa Mundial de Fútbol 2014. Cuenta con una programación producida en alta calidad digital (HD) y busca apoyar el cambio en las políticas públicas del deporte. Su programación cuenta con subtitulado oculto en vivo.

34 TATETI es el Primer Canal Digital Abierto 360 de Latinoamérica, con sede en Buenos Aires; disponible a nivel Panregional. 
Es el canal de televisión del INSTITUTO NACIONAL DE CINE Y ARTES AUDIOVISUALES. Para la promoción y difusión, que el INCAA viene desarrollando en otras áreas, es una de las atribuciones específicas que la Ley de Cine le otorga y a la vez le exige, lo que convierte a INCAA TV en la posibilidad de una herramienta fundamental para sostener esta tarea para aportar a una televisión que sea espejo e intérprete de la sociedad, con inteligencia, pluralidad y compromiso, y con un fuerte sentido de responsabilidad frente a las audiencias de todo el país.

Es un eslabón de una cadena sustentable en el tiempo para el crecimiento real de un sistema de medios públicos que contenga a todos los argentinos.El Canal se difunde a través de la Televisión Digital Terrestre (TDT) dentro de la Plataforma de RTA (Radio y Televisión Argentina), pudiendo ser recibido por los operadores de las áreas de cobertura correspondientes a través de los mismos decodificadores destinados a los televidentes37.

\section{TECtv. La señal de la Ciencia}

Es un canal educativo operado por el Ministerio de Ciencia, Tecnología e Innovación Productiva, es una de las señales que se distribuyen a través del Sistema de Televisión Digital Terrestre en Argentina y la primera en HD. El proyecto fue inspirado y presentado en la exposición del mismo nombre. En septiembre de 2011, Tecnópolis TV inició la transmisión con una programación regular en modalidad de prueba en la frecuencia de $527 \mathrm{MHz} 38$. Es el primer canal público destinado a la difusión de la ciencia, la tecnología y la industria nacional. Cuenta con una pro-

36 Funciona desde el 1 de enero del año 2011. Tiene el objetivo prioritario de difundir las películas de la cinematografía nacional en sus distintos géneros y formatos, además de incluir ciclos de cine latinoamericano y presentaciones especiales de films relevantes de la producción mundial.

37 El Canal es de acceso público y gratuito para todos los operadores de Cable y Satélite dentro del territorio nacional para su retransmisión completa dentro de sus paquetes analógico y digital, sin costo extra para los abonados (dentro del paquete básico) y sin ningún tipo de encripción.

38 El 18 de abril de 2012, se puso oficialmente en marcha el nuevo canal TEC-Tecnópolis TV, cuya programación apunta a desmitificar la imagen de la ciencia como una materia aburrida. Participarán de la programación el doctor en biología e investigador del Conicet, Diego Golombek; el matemático y periodista Adrián Paenza, entre otros. 
gramación íntegramente producida y emitida en HD, para mostrar a la ciencia como una actividad generadora de crecimiento económico. Su contenido está orientado al público joven.

\section{Universidad y medios de comunicación:}

\section{Las radios y los canales universitarios}

Las universidades tienen mucho para decir. Y en una era de comunicaciones, su presencia en los medios adquiere una importancia incuestionable. Radio y televisión son hoy dos soportes donde la universidad, envalentonada por la Ley de Servicios de Comunicación Audiovisual, los desarrollos tecnológicos y un reclamo social por nuevas voces, tanto para comunicar y hacer hablar a sus aulas, como para aportar su voz en el debate sobre el rol de los medios, en general, y la importancia de la palabra pública, en particular.

El programa Polos y Nodos Audiovisuales ${ }^{39}$, y ahora se encuentran en la proyección de sus propios canales de televisión, que abrirán el juego a nuevas formas de comunicación local. Las radios universitarias, en tanto, se posicionan también en su rol de participación activa en la defensa y promoción del espacio de la comunicación pública. “Las universidades trabajaron fuertemente por la Ley de Servicios de Comunicación Audiovisual, y en ese marco terminaron siendo instituciones que podían apoyar la nueva política de comunicación en el país, mirando el mapa del nuevo escenario comunicacional, las universidades públicas han tenido en estos últimos años un desarrollo formidable. Se concretó la creación de unidades de producción audiovisual en cada lugar donde hay una universidad, por lo que estamos hablando de las veinticuatro provincias argentinas, en cada una hay profesionales de primer nivel trabajando, hay estudios y equipamiento, es decir, hay un escenario muy propicio con potencialidad y capacidad instalada en el territorio" 40 .

39 El Programa Polos busca instalar y fortalecer las capacidades para la producción nacional de contenidos para la TV Digital, promoviendo la igualdad de oportunidades y la disminución de asimetrías entre provincias y regiones, materializando así el artículo 153 de la Ley 26.522 de Servicios de Comunicación Audiovisual, que expresa la necesidad de crear nuevos conglomerados productivos para la promoción y defensa de la industria audiovisual nacional.

40 DUCATENZEILER Claudia, coordinadora de la Red Nacional Audiovisual Universitaria (Renau), http://informacionpresupuestaria.siu.edu.ar/DocumentosSPU/Cuadernillo-decada-ganada.pdf 
El fomento a la producción audiovisual universitaria está estratégicamente ligado al desarrollo de la TDA (televisión digital abierta) ya que, para abastecer a esta nueva plataforma mediática, se conformaron entre otras iniciativas los polos y nodos audiovisuales, encabezados por las universidades públicas. “Es una magnífica experiencia que sirvió para testear capacidades productivas regionales" con el fin de "nivelarlas aportando recursos en capacitación, en producción y en tecnología. La primera experiencia fue lo que se llamó Plan Piloto de Testeo y Demostración Cada polo debía hacer 10 horas, lo que implicaba en total 90 horas de televisión y 31 ciclos terminados. Este año los polos y nodos se lanzaron a producir alrededor de 40 series de 12 capítulos cada una, simultáneamente en todo el país. Los resultados son maravillosos porque desde Tierra del Fuego a Jujuy, y de la cordillera al Río de la Plata, todos los argentinos estamos representados. Una paleta federal de producción, con capacidad de producir en todos los territorios"41.

Otro eje de trabajo de las productoras audiovisuales universitarias son sus próximas señales de televisión. La Ley de Servicios de Comunicación Audiovisual le da al tercer sector una franja importante de adjudicación de señales. Hoy las universidades públicas tienen como proyectos prioritarios en lo audiovisual la creación de señales locales, y en eso se está trabajando Esto fortalece a la televisión pública, creando y diseñando canales del tercer sector universitarios de calidad, que son canales locales, haciendo crecer el espacio audiovisual local y territorial, o sea federalizando la comunicación.

Las radios universitarias son otros actores claves de creciente importancia en la configuración del nuevo mapa de medios. “En tanto radios públicas, las radios universitarias consideran esencial establecer un modelo de comunicación democrático, que permita la apertura de los medios a una pluralidad de voces que si no fuera por la intervención del Estado quedarían marginadas de cualquier posibilidad de participar con las herramientas de la cultura mediática"42. La actual comisión directiva

42 ALBARRACIN, Santiago vicepresidente de Aruna (Asociación de Radios de Universidades Nacionales). en http://informacionpresupuestaria.siu.edu.ar/DocumentosSPU/Cuadernillo-decada-ganada.pdf 
de Aruna, que asumió en abril de 2011, ha definido como líneas prioritarias de gestión la participación activa de las radios universitarias en la defensa y promoción del espacio de la comunicación pública. "Hacia adentro, Aruna trabaja en fortalecer su carácter reticular. La asociación nuclea a 42 radios de treinta y dos universidades nacionales dispersas por todo el país, generando una red que abarca casi todo el territorio nacional. Es una red tan amplia como la de Radio Nacional.

Eso le confiere un potencial enorme para la participación en el desarrollo de políticas públicas". Esa ventaja potencial comenzó a tomar cuerpo con la producción de un noticiero radial semanal, Ilamado ¡Vamos las radios!, que sale en vivo en Radio Universidad Nacional de La Plata y se sube de inmediato a un servidor para que las radios hermanas lo puedan bajar y pautar en sus programaciones.

En la creación de nuevas radios, en la convocatoria que los diferentes niveles del Estado nos formulan de manera cada vez más frecuente, en la participación en foros y espacios de intercambio académico, y en la participación en órganos colegiados consagrados por la Ley de Servicios de Comunicación Audiovisual. La gestión de un medio -o de varios medios universitarios-, no sólo fortalece la imagen pretendida por cada casa de estudio, es también un promotor de conocimientos, herramientas y producciones en muchas disciplinas, tanto en las ciencias duras como en las ciencias sociales. Es fundamental que una universidad cuente con dispositivos para difundir lo que se hace en sus laboratorios, aulas y territorios, es un rasgo positivo que debería profundizarse. Los medios universitarios son legitimadores de la universidad pública, abierta, democrática y cogobernada, un modelo argentino reconocido en el mundo entero. 


\section{Conectar Igualdad}

"La distribución del ingreso, la palabra y el conocimiento son bases indisociables de una alternativa democrática y emancipatoria"43

La creación del Programa Nacional Conectar Igualdad de incorporación de las TIC al sistema educativo bajo el modelo uno a uno, es una política de inclusión digital de alcance federal, Conectar Igualdad recorre el país distribuyendo netbooks a todos los alumnos y docentes de las escuelas secundarias, de educación especial y de los institutos de formación docente de gestión estatal.

La Ley Nacional de Educación № 26.206 instituye el derecho de enseñar y aprender, a la vez que establece como uno de los fines y objetivos de la política educativa nacional, el desarrollo de las competencias necesarias para el manejo de los nuevos lenguajes producidos por las Tecnologías de la Información y la Comunicación. Este Programa nace como respuesta a estos requerimientos. Propone el desarrollo de contenidos digitales que puedan utilizarse en propuestas didácticas las cuales apuntan a transformar los modelos de enseñanza y a dinamizar nuevos procesos de aprendizaje. En la sociedad actual caracterizada por procesos de cambio permanente y por una demanda cada vez mayor de conocimientos sobre nuevas tecnologías se hace necesario la incorporación, integración y aprovechamiento pedagógico de las Tecnologías de la lnformación y Comunicación (TIC) en el Sistema Educativo. El empleo de las TIC debe ocupar un lugar estratégico en la agenda educativa de las escuelas para lograr aprendizajes significativos en el marco de la sociedad de conocimiento. En este contexto, el Programa Conectar Igualdad supone un gran desafío, además de una oportunidad única. Esta modalidad promueve el acceso de todos los alumnos a equipos personales. ${ }^{44}$

Esta iniciativa tiene el objetivo de reducir las brechas sociales, digitales y educativas, garantizando la igualdad de oportunidades de acceso y uso de estas tecnologías. Esta política profundiza las estrategias del

43 CALCAGNO, Eric citado por la Presidenta Cristina Fernández de Kirchner en el Discurso de Apertura de la Asamblea Legislativa 2014 http://tiempo.infonews.com/nota/60580/el-discurso-del-estado-el-estado-del-discurso 
Estado respecto de las TIC y propicia a su vez, mayores y mejores accesos a la información y al conocimiento. La propuesta se fundamenta en la hipótesis de una computadora personal para cada niño o niña en edad escolar. Diseñada por Nicholas Negroponte, director del Media Lab del $\mathrm{MIT}^{45}$, un ingeniero, que en el 2005 desarrolló una computadora de bajo costo. El proyecto se llamó OLPC (One Laptop Per Child) y el objetivo fue venderlas a los Estados Nacionales de los países más pobres del mundo, para reducir la brecha social y digital de las poblaciones más jóvenes una computadora liviana, pequeña, barata (100 dólares era la promesa que Negroponte les sugirió a las grandes compañías). La implementación de otras iniciativas similares se da en simultáneo en Latinoamérica ${ }^{46}$ y el mundo. Los Estados nacionales llevan adelante políticas de alfabetización digital basadas en la implementación de modelos uno a uno. A partir de estos planes, se distribuyen computadoras portátiles a cada estudiante para ser utilizadas en las escuelas y en los hogares. En el caso de nuestro país, varias provincias como San Luis, Río Negro, La Rioja, Ciudad de Buenos Aires lanzaron sus planes provinciales de alfabetización digital.

45 MIT Media Lab (también conocido como el Media Lab) es un laboratorio dentro de la Escuela de Arquitectura y Planificación en el Instituto de Tecnología de Massachusetts. Fundado en 1985.

46 En Brasil, el plan “Um Computador por Aluno" (UCA) comenzó en el año 2007 a partir de una serie de pruebas piloto, distribuyendo computadoras portátiles donadas a los alumnos de escuelas de Palmas, Piraí, Porto Alegre, São Paulo y Brasilia. En 2010, se pasó a una segunda etapa del UCA que proyectó un alcance mayor, financiando la compra de 150.000 computadoras que el Ministerio de educación donó a 300 escuelas de todo el territorio brasileño (10 escuelas por estado). En 2011, la tercer parte del Programa UCA (que pasó a conocerse como PROUCA) el Estado Nacional proveyó de fondos para la adquisición de 1,5 millones de computadoras a través del Banco Nacional de Desarrollo (BNDES) de Brasil, que se encuentran a disposición de los estados y gobiernos locales que son quienes deben adquirir los equipos a partir de créditos a largo plazo, con interés bajo y exento de impuestos por parte del BNDES, y un precio accesible garantizado por una licitación única nacional. En Haití se realizó desde el Ministerio de Educación y Capacitación Vocacional (MENFP) y el Banco Interamericano de Desarrollo (BID), un proyecto piloto en una escuela, durante un mes en un campamento de verano que contó con la presencia de 116 alumnos. A partir de esta experiencia se proyectó la realización de otro piloto en mayor escala que debía proveer laptops a 13.700 estudiantes de $2^{\circ}$ a $5^{\circ}$ grado, y a 500 docentes en 40 comunidades y 60 escuelas. La catástrofe* sufrida por el pueblo haitiano en 2010 generó la suspensión de su implementación. En 2008, la Dirección General de Tecnologías Educativas (DIGETE) del Ministerio de Educación de Perú, lanzó el programa Una Laptop Por Niño. Se dirigió primero a las escuelas primarias de regiones más alejadas y pobres del Perú, y durante su primera fase se llegó a aproximadamente 560 escuelas y 40.000 estudiantes que recibieron computado $\neg$ ras. Para fines del 2009 se habían distribuido 170.000 y al año 2011 se llegó a las 300.000. El Plan "Conectividad Educativa de Informática Básica para el Aprendizaje en Línea" (CEIBAL), desarrollado en Uruguay desde 2007, es la primera iniciativa en modelos 1 a 1, en el mundo, que tuvo un carácter de cobertura total para república. Entre sus objetivos se destaca el de "promover la justicia social mediante la promoción de la igualdad de acceso a la información y herramientas de comunicación para todo nuestro pueblo".37 Este proyecto se desarrolla con las computadoras XO elaboradas por OLPC. 
El modelo uno a uno significa un avance respecto de las políticas de alfabetización digital implementadas con anterioridad en Argentina desde el sistema educativo, en tanto, en este caso, la computadora es una herramienta que pertenece al alumno, y no ya a la escuela. Este modelo tiene tres fundamentaciones básicas. Una económica, que asocia la introducción de las Tics en la educación con un próspero desarrollo de saberes que permitan a los alumnos introducirse en el sistema laboral a partir de una mayor competitividad y productividad. También se habla de una fundamentación educativa vinculada con la eficacia de los modelos educativos por realizar un aporte a nuevas formas de trabajar, pensar y vivir, mejorando la inserción escolar y el interés de los estudiantes por asistir a clases, estimulando la participación e inclusión de los mismos en las instituciones educativas. Por último, aparece la fundamentación social de los modelos uno uno, que refiere a la intención de equiparar las oportunidades de acceso y a la disminución de las brechas digitales. De esta manera se busca promover la equidad, y ofrecer oportunidades no sólo a quienes reciben (o utilizan) las computadoras, sino también a sus familias y a los miembros de su comunidad ${ }^{47}$.

\section{Descripción del Programa}

El 6 de abril del 2010, a través del Decreto 459/10 del Poder Ejecutivo Nacional, se crea el Programa Nacional Conectar Igualdad de la República Argentina. Establece el inicio de una política de inclusión educativa que busca democratizar el acceso y uso de las Nuevas Tecnologías de la Información y la Comunicación en todo el territorio nacional, para mejorar las condiciones de los aprendizajes. La igualdad en el acceso es la condición para la formación de los estudiantes y docentes en las competencias digitales adecuadas a su desarrollo personal, cívico y profesional en la Sociedad del Conocimiento. En aquel momento, Cristina Fernández reflexionaba sobre el término Igualdad "es la palabra distintiva que siempre han perseguido aquellos argentinos que han estado comprometidos con el desarrollo del país desde 1810 para adelante", decía. Y agregaba "creo que debe ser el signo distintivo también de este Bicentenario, seguir

47 SEVERIN, Eugenio “Modelos Uno a Uno en América Latina y el Caribe Panorama y perspectivas http://idbdocs.iadb.org/ wsdocs/getdocument.aspx?docnum=35838865 
persiguiendo la igualdad, contra viento y marea, contra pequeños pero poderosos intereses que necesitan de las desigualdades muchas veces para, en su criterio, poder seguir teniendo poder. Yo creo que la igualdad es el gran instrumento liberador de las sociedades, de los pueblos y del mundo."48 El Plan se propone la distribución de 3 millones de netbooks, una para cada alumno y docente de las escuelas públicas de educación secundaria y educación especial; y aulas digitales móviles para alumnos y docentes de Institutos de Formación Docente. El decreto contempla, además, la formación de los profesores y la elaboración de propuestas educativas para mejorar el proceso de enseñanza aprendizaje y se fundamenta en el artículo 14 de la Constitución Nacional, que establece el derecho a enseñar y a aprender, y en la normativa educativa sancionada en el 2006, Ley 26.206, de Educación Nacional, que promueve la equidad, inclusión y calidad educativa. La Ley establece la incorporación de las TIC en los distintos niveles, modalidades educativos y a la formación docente. Establece el acceso a la información y al conocimiento como un derecho que debe estar garantizado por el Estado (artículo 7). Y en el artículo 8 dice que "la educación brindará las oportunidades necesarias para desarrollar la formación integral de las personas a lo largo de toda la vida" (artículo 8) ${ }^{49}$.

En la decisión de lanzar el Programa incluye la concepción de la escuela pública, no sólo como el espacio donde democratizar el saber y el aprendizaje sino, sobre todo, como un espacio para favorecer la igualación de los jóvenes ciudadanos. La incorporación de las netbooks en las aulas es una estrategia que busca también calidad educativa y que permitirá disminuir la brecha digital y las brechas sociales. En imprescindible dotar de sentido pedagógico al programa desafío fundamental de los docentes. Comprender a la netbook como una herramienta más del complejo sistema educativo, incorporarla en las prácticas, en el quehacer cotidiano. Usarla y reflexionar en torno a ella, establecer nuevas lógicas en el aula, abrir la posibilidad de ubicarse en un espacio de aprendizajes conjuntos, conocer entre todos, aprender con otros. El Estado, a partir de una decisión, de una planificación estratégica, que distribuye recursos, 
convirtiendo lo que antes era un privilegio (una netbook) en un derecho, que debe ejercerse, sentirse y hacerse consciente en las aulas.

También en los hogares entran las netbooks. Hogares distribuidos en todo el territorio nacional, con todas las disparidades que eso implica. Con la riqueza y pluralidad que caracteriza a los estudiantes de las escuelas públicas más la diversidad constitutiva de cada familia. En algunos hogares, las nuevas tecnologías circulan de manera casi natural, otros se esfuerzan para acceder a ellas y muchos otros que quizás no hubieran podido comprarla.

\section{Fundamentos}

El programa contempla el uso de las netbooks tanto en el ámbito escolar como también en la casa de modo tal que se logre un impacto en la vida diaria de todas las familias y de las más heterogéneas comunidades de la Argentina

Conectar Igualdad es una política de Estado que consiste en "proporcionar una computadora a alumnas, alumnos y docentes de educación secundaria de escuelas públicas, de educación especial y de Institutos de Formación Docentes, capacitar a los docentes en el uso de dicha herramienta y elaborar propuestas educativas con el objeto de favorecer la incorporación de las mismas en los procesos de enseñanza y de aprendizaje" . De acuerdo a la planificación establecida por el Ministerio de Educación de la Nación, se distribuirán 3 millones de netbooks en todo el territorio nacional con la intención de poder recuperar y valorizar la escuela pública a través de la reducción de las brechas digitales, educativas y sociales a lo largo y ancho del país.

Para que la entrega se haga efectiva, de acuerdo con el cronograma que establece el Comité Ejecutivo de Conectar Igualdad, cada Escuela debe inscribirse y generar una clave de Seguridad Social en la ANSES, registrando a la institución y su matrícula escolar. A partir de ese momento, se desarrolla una estructura que permite la ejecución del programa. Una vez completado el trámite de Seguridad Social, se instala un piso tecnológico en la Escuela (servidores, puntos de acceso, cableado, conectividad a internet, etc.) y comienza a tramitarse la firma de un comodato en el que entre los directivos, los alumnos y alumnas de la institución y sus 
padres, se hacen responsables de entregar, recibir y utilizar la computadora con el objetivo de "destinarla a fines formativos y de compartirla con su grupo familiar primario, comprometiéndose a no enajenarla de ninguna forma y bajo ninguna circunstancia o concepto."

\section{Estructura}

El Programa Conectar Igualdad ( $\mathrm{PCl})$ es comandado por un Comité Ejecutivo que se compone de cuatro organismos nacionales que regulan y ejecutan distintas etapas del mismo. Estos organismos son la ANSES, el Ministerio de Planificación Federal, Inversión Pública y Servicios, el Ministerio de Educación de la Nación y la Jefatura de Gabinete de Ministros. A partir de una planificación que los hace interdependientes, el PCI no podría desarrollarse sin el trabajo de cada uno de estos espacios. La interdependencia es una dinámica que implica ser mutuamente responsable y compartir un conjunto común de principios con otros.

La ANSES tiene entre sus responsabilidades, contribuir con la financiación del programa y definir y elaborar los instrumentos que fueran necesarios para la adquisición y distribución de todo el equipamiento (netbooks, servidores, etc.). Por su parte, el Ministerio de Planificación Federal, Inversión Pública y Servicios es el encargado de garantizar la conectividad de banda ancha en todos los establecimientos escolares del programa. Para ello se desarrollan distintas estrategias que permitan que la conectividad se adapte a cada escuela y se atienda a los requerimientos de cada provincia y región. Un ejemplo de ello son el programa "Argentina Conectada" y el programa "Internet para establecimientos educativos" que vinculan al Estado y al sector empresarial con la adjudicación de plataformas informáticas y la provisión de servicios de conectividad para cada institución escolar. La Jefatura de Gabinete de Ministros asume la responsabilidad de establecer políticas de seguridad física y lógica de todos los equipos y sistemas de redes que se entregan y gestionan para cada institución. Por último, el Ministerio de Educación de la Nación tiene a su cargo la definición de estrategias educativas que permitan llevar adelante el programa.

Dentro de la línea de desarrollo profesional docente, se tomó como punto de partida pensar la reflexión sobre el lugar del conocimiento es- 
colar, el lugar de la enseñanza, la autoridad pedagógica del docente y las distintas trayectorias escolares de los estudiantes

Estas computadoras se conocen como "educativas" puesto que no están pensadas para su comercialización al público, sino sólo para su utilización en contextos de enseñanza. Por la misma razón sólo está preparada para realizar tareas básicas como escribir documentos, dibujar, navegar por internet y escuchar música. Algunas de las características más interesantes de este diseño tienen que ver con la larga duración de su batería (preparada para mantenerse activa sin cargarse por varios días) pensando en su utilización en zonas más remotas con poco acceso a la electricidad. Una de las claves del bajo costo de estos equipos es la incorporación únicamente de software libre. Vienen cargadas por defecto con GNU-Linux ya que sus creadores se negaron a producir con Windows por los altos costos de dicho sistema operativo y por los complejos requerimientos técnicos que establecen para su instalación.

\section{Las Netbooks}

El Programa Conectar Igualdad distribuye netbooks producidas en Argentina, de distintas marcas (Bangho, CDR, Depot, Edunec, Exo, Lenovo, Maghallaes, Noblex, Positivo y Samsung) pero todas con las mismas características. Poseen un procesador Intel ${ }^{\circledR}$ Atom $^{\mathrm{TM}}$, un disco rígido de 160GB, memoria ram de 1GB, sistema operativo Windows 7 y también Linux Ubuntu, micrófono y cámara incorporados, pantalla de 10", 3 puertos USB, lectora de tarjetas, entrada para micrófono y auriculares y batería de 6 celdas. Estas computadoras son técnicamente iguales, o incluso mejores, que las que se encuentran en el mercado. Algunos medios intentaron deslegitimar la calidad de esta política pública . La diferencia radica en algunos contenidos que vienen instalados para la utilización de la computadora tanto dentro como fuera de las aulas.

En el escritorio de las netbooks hay tres íconos que indican: "escritorio del alumno"'escritorio del docente" $y$ "escritorio de las familias". En cada uno de ellos se encuentran distintas aplicaciones, programas, sugerencias, manuales y propuestas para cada destinatario. En la portada del escritorio diseñado para los alumnos de las escuelas secundarias se anuncia: "Al encender su máquina, cada chico estará a un clic de los libros clásicos de la literatura universal, nacional y latinoamericana, de juegos didácticos, 
de videos educativos de Educ.ar y Encuentro, de cursos autoasistidos de informática, ofimática y técnicas de estudio y del material obligatorio de todas las materias de su curso."

Además seis botones de colores permiten acceder a juegos didácticos, videos del portal educ.ar y de Canal Encuentro, programas, actividades para cada materia, libros digitalizados y cursos de informática, ofimática y técnicas de estudio (entre otros).

Para los docentes el diseño de su escritorio es distinto, de más sobrio, con contenidos pedagógicos y didácticos. Propuestas de secuencias, actividades recorridos específicos para cada materia; cursos de ofimática, producción de contenidos digitales, estrategias de aprendizaje, etc; programas y software educativo y una biblioteca nutrida de libros digitalizados, enlaces de interés y videos, circulan en el espacio diseñado para que los docentes "puedan enseñar disponiendo de mayores herramientas".

El escritorio para las familias es de un diseño sencillo, con acceso a un curso de manejo de internet, un manual de uso responsable de las TICs, un listado de enlaces de interés y un glosario de las palabras y conceptos más frecuentes en contextos afines a la informática y las nuevas tecnologías. Su objetivo es "integrar a todos los miembros de la familia en el mundo digital".

\section{Decisiones en Red}

Conectar Igualdad es una más de las políticas públicas que lanza la gestión del Estado Nacional que comenzara con Néstor Kirchner en 2003. Las políticas públicas no pueden pensarse por fuera de este contexto, de esta matriz sociopolítica que lo atraviesa "toda política de Estado se supone inserta en un modelo de país, con su carga ideológica y política. En función de un determinado proyecto nacional, se educa, se orienta culturalmente, se deciden los lineamientos económicos y, también, se tiene la mirada sobre la cuestión social". Conectar lgualdad es parte la políticas públicas impulsadas desde el Gobierno, como la Asignación Universal por Hijo $(\mathrm{AUH})^{*}$, considerada revolucionaria por su rol fundamental en la disminución de los índices de pobreza e indigencia.

Proyectarse, siempre, hacia el futuro. Imaginar el largo plazo. La 
mera implementación de una política pública genera instantáneamente modificaciones en la vida de las personas. Se trata de procesos más largos y complejos que no comienzan ni terminan con la aplicación de la misma, sino que conllevan múltiples recorridos de carácter estructural, con disparidades en la apropiación e implementación. Cuando se planifica estratégicamente a un país, se lo hace de manera integral y no a partir de decisiones aisladas. Si hacemos el ejercicio de pensar de manera ideal a las políticas públicas como parte de una gestión integral, podemos imaginar de qué manera está proyectándose este futuro: los niños de hoy, aun cayendo en el riesgo de generalizar, nacen, están sanos, van al médico, se alimentan, van a la escuela, juegan, conocen otros chicos iguales y distintos a ellos. Aprenden, preguntan, construyen. Van al colegio secundario y reciben las netbooks de Conectar Igualdad, que son hechas en nuestro país a partir del fomento a la industria nacional y del valor que a ésta se le otorga. El Estado compra esas netbooks a las fábricas nacionales, por lo tanto el dinero circula hacia el interior del país. Para desarrollar la industria es necesario fomentar el desarrollo de la ciencia nacional y de la producción de saberes técnicos.

En el discurso de lanzamiento, la Presidenta anunciaba la decisión de "que todos los chicos de las escuelas secundarias públicas y sus maestros, sus docentes, puedan tener este instrumento, y además, el que termina, el que llega al final, se lo lleva a su casa. Porque lo importante no solamente es lograr que ingresen a la escuela sino que el gran desafío, por supuesto, es que terminen la escuela secundaria." Se piensa en educar para construir una sociedad más justa, una sociedad incluida, con ampliación de derechos en la que los sujetos vuelvan a creerse merecedoras de esos derechos. Conectar Igualdad, facilita herramientas para el aprendizaje, entendido como un proceso que permite la apropiación del conocimiento y la construcción de saberes colectivos. Concibe a docentes y estudiantes como productores de conocimiento, y a las familias reintegrándose en las escuelas. La escuela como institución que vuelva a ser ese lazo conector con la familia, espacio de contención y diálogo que durante décadas quiso ser destruido. "Con Conectar Igualdad se busca incorporar a la familia al proceso educativo y de la información. Volver al compromiso entre la familia y la escuela." Porque las netbooks no se incorporan sólo en las escuelas, son herramientas que van a los hogares 
y se insertan en las familias abriendo puertas para quienes transitan la educación secundaria y para los integrantes del grupo familiar. "Las familias de los estudiantes se están apropiando de los nuevos modos de comunicarse y conocer, que favorece el uso de las tecnologías. Así, ampliamos las posibilidades de desarrollo social y cultural de nuestra población, y avanzamos un paso más hacia la construcción de una ciudadanía con igualdad de oportunidades", afirmó Diego Bossio, Director de la Administración Nacional de Seguridad Social (ANSES).

Se trata de procesos que son más largos que la mera implementación. Se trata del Estado presente, tal como sucede con la Ley de Servicios de Comunicación Audiovisual, su aprobación y promulgación no alcanzaron para que la pluralidad y democracia en el campo de la Comunicación sean una realidad efectiva y creciente. Está dado el primer paso. Pensar las políticas públicas desde esta perspectiva es pensar en el largo plazo y no en cubrir los baches de manera provisoria. En imaginar un futuro y empezar a construirlo. 



\section{Diálogo en las tensiones}

\section{Los estudiantes}

"Las particularidades de los jóvenes hoy radican en la relación que tienen con los medios de comunicación y las tecnologías"50

"Nuestro pensamiento nos ata todavía al pasado, al mundo tal como existía en la época de nuestra infancia y juventud, nacidos y criados antes de la revolución electrónica, la mayoría de nosotros no entiende lo que ésta significa. Los jóvenes de la nueva generación, en cambio, se asemejan a los miembros de la primera generación nacida en un país nuevo. Debemos aprender junto con los jóvenes la forma de dar los próximos pasos; Pero para proceder así, debemos reubicar el futuro. A juicio de los occidentales, el futuro está delante de nosotros. A juicio de muchos pueblos de Oceanía, el futuro reside atrás, no adelante. Para construir una cultura en la que el pasado sea útil y no coactivo, debemos ubicar el futuro entre nosotros, como algo que está aquí listo para que lo ayudemos y protejamos antes de que nazca, porque de lo contrario, será demasiado tarde" ${ }^{\prime 51}$

Ahora bien, ¿cuáles son nuestros sujetos?, ¿Quiénes los protagonistas de esta historia? ¿cómo transitan sus Estudios Superiores y a la vez, transitan su juventud en un contexto de profundos cambios? Se trata de abordar el desarrollo conceptual y analítico de algunas transformaciones que se han ido produciendo en los órdenes de la modernidad, estructuradoras de las prácticas e imaginarios subjetivos e institucionales, en el marco de los procesos de formación y transmisión cultural contemporáneos.

50 MORDUCHOWICZ Roxana, directora del programa Escuela y Medios del Ministerio de Educación de la Nación. 
Es necesario, antes de mostrar los resultados respecto de los consumos de internet, mail, televisión y cine, decir que no hay una única manera de ser joven y que, consecuentemente, esos diversos modos en que se manifiestan las culturas juveniles están dados por los atravesamientos de clase social, género, etnia, edad, lugar de pertenencia y por los capitales materiales y simbólicos que los sujetos posean.

Comprendemos que los procesos de producción de sentidos que despliegan los sujetos en su relación con los medios y las tecnologías en el marco de múltiples y diversas mediaciones, están inscriptos en una sociedad eminentemente mediatizada. Sentidos que no pueden ser analizados desde el modelo clásico "emisor-mensaje-receptor", como un intercambio de mensajes que producen determinados efectos, sino que requieren ser comprendidos desde la perspectiva de la interacción simbólica, en tanto proceso complejo que involucra tanto a la producción como a la circulación, el consumo y la resignificación de las formas simbólicas en contextos determinados. Los procesos comunicacionales en los que los sujetos intervienen están dados por el renovar, el repetir y el reproducir constante; de esta manera las prácticas sociales fortalecen la trama cultural. Estas prácticas, al ser analizadas desde la mirada comunicacional, son leídas como enunciaciones que producen los sujetos sociales (pronunciamiento sobre la forma en cómo miro en la tele, para qué uso internet, cómo me comunico con los demás). Al elegir "mirar desde la comunicación" ${ }^{\prime 2}$, se pretende entender el mundo en que vivimos mediante interpretaciones, desde la lógica de la producción y la lucha por los sentidos, ese es el lugar de entrada para interpretar las prácticas históricas de los sujetos sociales, en este caso las prácticas culturales de los sectores juveniles y sus modos de relacionarse con los medios.

“La universidad es en general un ámbito de aprendizaje no sólo vinculado con lo académico, sino de aprendizajes sociales y políticos"53. El ingreso al mundo universitario debiera tomarse como una problemática muy valorada para el diseño de estrategias pedagógicas o vocacionales. 
Poco sabemos y hemos estudiado, en el caso de las características de accesibilidad, de sus constituciones como grupo etario, de sus intereses epocales en lo específico y, aún, de cuál es nuestra mirada definitoria de ese ingreso y permanencia en los estudios universitarios de unos jóvenes que recién al egreso puede decirse que comienzan a dejar de adolecer (superando incipientemente la adolescencia al momento de su potencial incorporación al mundo laboral profesional).

Con la intención de brindar algunos datos que nos acerquen a estos territorios inexplorados, se aporta una consideración conceptual acerca de las características específicas de la constitución etaria, de las expectativas profesionales que observan al momento de su ingreso a los estudios universitarios en comunicación.

Para elaborar este perfil se diseñó un sondeo respecto a inquietudes, expectativas y características de los alumnos que hicieron el curso de Ingreso a la Carrera. Además, se analizaron datos de la Encuesta Juventud 2011 Ingresantes a la Facultad de Periodismo y Comunicación Social ${ }^{54}$ que se realizó el jueves 16 de marzo a los ingresantes 2011 (495 encuestas). También se indagó sobre los vínculos que se construyen entre la instancia del curso de Ingreso y el primer año de la Carrera como proceso y espacio de encuentro entre las expectativas y características de los alumnos ingresantes, bajo los siguientes ejes de trabajo: imaginario acerca de la Profesión y la Facultad; Modos de aprender, y Prácticas comunicacionales cotidianas. Finalmente, se realizaron foros o entrevistas colectivas, en diversas instancias del proceso de recolección y análisis, con el objeto de validar y profundizar las categorías analíticas desarrolladas en el transcurso de la investigación. Esta estrategia, supone la conformación de espacios de reflexión colectiva, que no reemplazan las estrategias precedentes de relevamiento de entrevistas individuales. 


\section{Imaginario acerca de la Profesión y la Facultad}

Esta dimensión se refiere al imaginario respecto de la Facultad y la profesión, teniendo en cuenta el marco de la elección de la carrera, en un recorrido que, hipotéticamente, se inscribe en el proyecto de vida de cada joven. Consideramos fundamental una aproximación a los contextos de situación de la elección de la carrera, las motivaciones, las expectativas, los procesos de decisión, los temores y los interrogantes de los jóvenes ingresantes. De esta manera es posible reconstruir las respuestas y las posiciones que van configurando lo imaginario. Por otro lado, analizamos el contexto familiar, biográfico y espacial (los lugares de origen) que ha condicionado la elección y las expectativas. Y además, el imaginario respecto a la profesión, los modelos profesionales, las imágenes y representaciones acerca del estilo de vida del periodista y/o comunicador, el interés por desarrollar una determinada práctica profesional. El análisis de las expectativas permite indagar la distancia que puede existir entre éstas y la oferta educativa de la Facultad, así como anticipar ciertas prácticas como estudiantes también definidas en torno a variados intereses.

\section{Prácticas Comunicacionales Cotidianas}

Relacionadas con la producción social del sentido, de lo que acontece en la articulación dinámica entre los productos culturales y mediáticos y los usos, apropiaciones y resignificaciones que de ellos hacen los jóvenes. Remite a los sistemas de sentido, circulantes entre los jóvenes que ingresan a la Universidad, dependientes de los contextos socioculturales generacionales. Si se considera a la comunicación como una producción social de sentidos: "la comunicación trascenderá el ámbito exclusivo de los medios para recuperar el sentido experiencial del término: diálogo, intercambio, relación de compartir; para así ampliar la mirada asociada al acto de informar, de transmitir, de emitir" 55 , los sentidos son socialmente construidos y reconstruidos desde la cotidianeidad, lo que implica reconocer instancias comunicacionales en las prácticas sociales. Interactúan con los mensajes (textos, signos y códigos), los agentes culturales (que otorgan significado desde un contexto) y la "realidad" (lo

55 KAPLUN, Mario "El comunicador popular", cap. 1: Modelos de educación y modelos de comunicación. Ed. LumenHumanitas. Argentina. 1996 
referente), es fundamental observar: las totalidades, los rasgos diferenciales de las comunicaciones interpersonales, las no verbales, las fácticas y las masivas.

Asimismo, hemos considerado dos planos en las prácticas comunicacionales: los referidos a la producción y los referidos al consumo (aunque mutuamente imbricados). Prestamos especial atención a la observación de las actuaciones en los encuentros, escenarios y rituales; a los grados de autonomía, de conformidad, de consenso, de negociación y de oposición en la situación de consumidores culturales o receptores mediáticos, vinculados con diversos tipos de experiencias culturales que aportan los jóvenes; a la construcción y apropiación de capital cultural conformado por prácticas, valores y habilidades; a la organización y selección de espacios de consumo; a los grados de implicación, el alcance de los medios como mediadores, las agendas de recepción y consumo de los jóvenes, las identificaciones, los imaginarios y los placeres que se juegan en las prácticas comunicacionales cotidianas. El cruzamiento entre estas prácticas y otras dimensiones de análisis brindará elementos para comprender los horizontes de expectativas o campos de significación (representados por ejemplo en los modelos de comunicadores sociales como vehículos de una modalidad comunicativa) a partir de los cuales los jóvenes estudiantes hacen sentido.

\section{Modos de Aprender}

Para la indagación de lo que configuramos como la dimensión que incluye los modos de aprender de los ingresantes y sus prácticas habituales de estudio, partimos de una concepción del sujeto del aprendizaje que no se ubica en una única perspectiva psicológica o social, sino que recoge las aportes de diferentes vertientes teóricas que tienen en común el entender al sujeto que aprende como un sujeto activo, producto y productor de la cultura, que a través de su acción sobre el medio construye tanto los conocimientos como los esquemas de interpretación del mundo que lo rodea. Pensar el sujeto de aprendizaje supone un sustento teórico y un posicionamiento práctico que hacen referencia a las relaciones entre el sujeto que enseña, el sujeto que aprende y el objeto de conocimiento. "Sin dudas, el saber acerca de ese protagonista 
fundamental del acto educativo que es el alumno, tiene un alto impacto en las labores pedagógicas en cualquier nivel o modalidad del sistema educacional. Ello se refleja particularmente en la calidad de los vínculos de trabajo y en la calidad de los logros que surjan de los procesos enseñanza-aprendizaje" ${ }^{56}$. Se concibe entonces al sujeto de aprendizaje como un sujeto mediatizado por su inserción socio-cultural, con componentes afectivos y cognitivos que no escapan a dicha inserción y que tampoco operan de manera disociada, tanto en lo que se refiere a la apropiación del conocimiento propiamente dicho, como a lo inherente a la convivencia institucional. Desde esta perspectiva, contemplando estas variables, se describió a los estudiantes ingresantes.

\section{Caracterización}

Para la caracterización de los estudiantes tuvimos en cuenta datos personales, laborales y educacionales.

\section{Datos Personales}

- Edad: El mayor porcentaje de ingresantes está comprendido entre los 17 y los 22 años, que representa el $73 \%$ del total de los encuestados (dato agrupado) siendo el grupo más numeroso los recientemente egresados del nivel medio.

- Sexo: Se distribuye equitativamente, según los datos de la encuesta realizada en el 201157 , ingresaron un $45,9 \%$ de mujeres y un $53,9 \%$ de varones.

- Procedencia: Frente al 50 \% de platenses (considerada La Plata y alrededores) nótese el alto porcentaje de ingresantes del resto de la Provincia de Buenos Aires (39\%), y el relativamente elevado porcentaje de ingresantes de otras provincias (9\%). En general los que contestaron la opción "otros" son extranjeros, ya sea que están viviendo en La Plata o porque se encuentran en un intercambio.

56 TENTI FANFANI, Emilio: "La escuela en el círculo vicioso de la pobreza", en Cuesta abajo. Ed. Unicef- Losada. 1993.

57 Encuesta Juventud Ingresantes a la Facultad de Periodismo y Comunicación Social UNLP. Observatorio de Jóvenes, Comunicación y Medios Facultad de Periodismo y Comunicación Social. UNLP 


\section{¿Con quién viven?}

El $65 \%$ de los ingresantes conviven con un núcleo familiar representado en un $45 \%$ con los padres más el $20 \%$ con familiares. Es bajo el porcentaje que vive solo. El alto porcentaje en la opción "otros" se debe a que allí se incluyeron a los que manifestaron "vivir solo" "pensiones" que no se encontraban entre las opciones. Solo el $4 \%$ de las madres no trabaja y el 2,2\% de los padres. Casi el $50 \%$ de las madres tiene estudios terciarios o universitarios completos, mientras que en el caso de los padres solo llega casi al 35\%.Otro dato interesante es que menos del $20 \%$ de los padres y las madres tiene formaciones mínimas como la escuela primaria. En tanto que apenas el $1 \%$ no posee ninguna formación.

\section{Situación Laboral}

- ¿Trabaja? Un $44 \%$ de la población encuestada trabaja, de los cuales un $83 \%$ hacen entre 20 y más de 30 horas semanales En cuanto al turno, el $56 \%$ a la mañana y el $34 \%$ a la tarde.

- ¿Buscan trabajo? Un 60 \% busca trabajo, porcentaje similar (64\%) al de los que no trabajan porque no encuentran.

- ¿Por qué no trabaja? Respecto a los que no trabajan cabe mencionar que un $25 \%$ está comprendido por los que no necesitan trabajo (6\%) y los que prefieren estudiar (19\%), de lo cual puede inferirse que tienen la situación económica resuelta.

- Turno en que trabajan El 55\% de los encuestados trabaja durante el turno mañana; el $35 \%$ en el turno tarde, el $9 \%$ en el vespertino; un $10 \%$ con turnos alternados y un $5 \%$ por la noche.

- Relación del trabajo con la Carrera: Si se analiza la relación entre el trabajo y la carrera, el 72 \% no guarda ninguna y sólo en el 9 \% la relación es total.

Pareciera que ya no hace falta caminar y "golpear puertas" para pedir un trabajo. El correo electrónico facilita. Por medio del e-mail es posible enviar el CV a distintas empresas e instituciones. Incluso, para hacer un trabajo a distancia -una tendencia cada vez mayor de las transnacionales-, una labor productiva en línea (el e-trabajo), donde tampoco es 
necesario salir de casa para trabajar. En tanto al uso del e-mail, la categoría "trabajo" aparece señalada haciendo referencia al uso de la cuenta en el ámbito laboral (la entrevistada señaló que se desempeña en el sector de atención al público, en el área de ventas) y. en relación a la "búsqueda de trabajo"; es decir, la estudiante usa su casilla de correo para enviar su CV o consultas a diversos lugares ofreciéndose o solicitando un puesto laboral (al momento de responder la encuesta, se dedica al cuidado de niños).

\section{Datos Educativos}

- Título Secundario: Si bien la mayoría representada por el 67 \% ingresaron con el título de bachiller, el $33 \%$ restante tiene título de perito mercantil $(25 \%)$ y técnicos el $8 \%$

- Otros estudios secundarios o terciarios: Según datos de la encuesta, se destaca que 42 ingresantes (10\%) han completado estudios terciarios, universitarios y no universitarios, 67 interrumpieron y 21 cursan actualmente, lo que hace un total de 130 (31\%).

- Los estudios a los que se hace referencia se discriminan en números absolutos agrupándolos en las siguientes áreas:

Área Educación. Profesorados:

- en Ciencias Sociales: total 20, de los cuales 3 completaron, 15 interrumpieron y cursan actualmente 2 ;

- en Lenguas: total 8, de los cuales 6 completaron y 2 interrumpieron;

- en Educación Inicial y EGB: total 12, 6 completaron, 4 interrumpieron y 2 cursan actualmente;

- con orientación artística: total 7, 4 completaron, 3 interrumpieron y 1 cursa.

\section{Área Técnica}

Dada la dispersión en la cantidad de Carreras por la cual los ingresantes han transitado, se consignan los totales: 4 completaron, 9 interrumpieron y 1 cursa actualmente, sobre un total de 14 . 


\section{Área Comunicación}

Dada su vinculación con la Carrera a continuación se explicitan las distintas opciones de formación:

- idiomas: 7 (4 interrumpieron y 3 cursan);

- diseño, imagen y sonido: 12 (1 completó, interrumpieron 6 y cursan 2);

- periodismo deportivo, locución: 10 (3 completaron, 2 interrumpieron y 5 cursan actualmente);

- computación, operador de PC: 9 (6 completaron y 3 interrumpieron) ;

- hay dos alumnos que iniciaron Carreras de Comunicación o Periodismo en otros países.

\section{Área Salud}

Capacitaciones de nivel técnico o Carreras universitarias: 8 (4 completaron, interrumpieron 3 y 1 cursa actualmente).

\section{Área Ciencias Sociales}

Total: 19 (completaron 3, interrumpieron 12, 4 cursan actualmente).

\section{Del escenario imaginado}

Las metas y motivaciones tienen relación directa con los estilos de aprendizaje y los posibles logros. De alguna manera, la idea de periodista y/o comunicador que los ingresantes tienen actualmente (qué hace, cómo vive) representa sus objetivos y su proyecto de vida. Idea que se va a continuar construyendo en el transcurso de la Carrera e incluso durante el ejercicio profesional.

Indagamos acerca del proceso de elección, otras opciones analizadas, acompañamiento familiar en la decisión, y cómo imaginan la vida de un periodista, su práctica profesional y su familia, temas de interés, y otras instancias de formación. Durante el proceso de elección de la carrera manifestaron marcada tendencia hacia carreras humanísticas, compartiendo el interés hacia Periodismo y Comunicación Social en especial: Letras, Derecho, Ciencias Políticas, Relaciones Públicas. También se mencionan intereses por: Crítica de arte, Diseño gráfico y artísticos (cine, dibujo, literatura y música). Se observa además que para definir la 
elección parten o bien del interés por temas: sociales, políticos y otros; interés por actividades como leer diarios y revistas, escribir, escuchar y hablar de música, realizar investigaciones o de prácticas en el área de la comunicación: participar o conducir programas de FM, confeccionar y dirigir periódicos escolares o locales, realizar pasantías en medios de comunicación como propuesta de Talleres de comunicación social del nivel medio. Surge fuertemente el interés por las redes sociales, y la comunicación transmedia. En relación con los motivos de elección de esta Carrera enuncian los siguientes: porque es corta, informa, es más amplia, completa, no es difícil, no hay examen de ingreso, no se estudia matemática y física, porque es gratuita, "le gustó el plan de estudios y los contenidos de la Carrera".

\section{Del análisis de la información de las encuestas hacemos la siguiente agrupación:}

a) Motivos relacionados con aspectos de formación o construcción personal (468) para lograr buen nivel de expresión (93), por gusto e interés (89), investigar (64), para ampliar la formación cultural (53), estar conectado con la gente (45), estar informado (38), opinar, ser activo en la sociedad (30), conocer los medios (17), tener posibilidades de trabajo (16), por vocación (13), por gusto por la lectura y la comunicación (10)

b) Motivos vinculados con la intervención social (159)

informar, esclarecer, transmitir, comunicar la verdad (73), influir en la gente (30), ayudar a la gente (27), hacer justicia y transformar la sociedad (18), por el poder (7), como medio educativo (4).

c) Motivos relacionados con el interés por la orientación profesional (109) para ser relator de fútbol o deportes (55), trabajar en la radio (17), producir en los medios (9), periodismo gráfico (8), musical y espectáculos (7), periodismo político (6), periodismo televisivo (4), corresponsal de guerra (1), planificación comunicacional (1), comunicación alternativa (1), gestionar .

d) Motivos relacionados con características y estilo de la Carrera y/o Facultad (42) porque es abierta, dinámica y gratuita (18), por las materias que abarca la Carrera (15), porque no tiene matemática ni ciencias exactas (9). 
Al imaginar qué hace un periodista, éste aparece fundamentalmente como alguien que tiene una importante función social, que está dada en la posibilidad de informar, esclarecer, averiguar, concientizar y hasta "mediar entre la gente y el gobierno". También lo consideran un trasmisor de noticias y mencionan actividades de investigación. Destacan asimismo la creatividad que implica esta profesión. Se sienten motivados por todo el desafío que implica por comunicar con las nuevas tecnologías, las redes sociales, la comunicación multi y trasnsmedia que se renueva vertiginosamente. Mencionan como condiciones necesarias para este profesional, la seriedad, la responsabilidad, e incluso el tener paciencia.

En cuanto a las características de la profesión, expresan de modo significativo que los envuelve el tema del riesgo, el temor, el peligro, las presiones. Señalan que el periodista se mueve en la antinomia entre la utopía del profesional que dice lo que quiere, lo que piensa, que discute, que presenta actitudes de oposición y las demandas y límites propios de los espacios laborales a los que accede, de modo que a veces "se llega a donde quieren los demás". Consideran a la profesión como no rentable y a la Carrera con poca salida laboral. Otro grupo menciona la sanción de la ley de Servicios de Comunicación Audiovisual como la promotora de nuevas posibilidades profesionales, en nuevos ámbitos. Respecto a su modo de vida, imaginan que es rápida, en movimiento, comprometida, complicada, "sin tiempos, de un lado a otro".

Al abrir la dimensión de análisis a cómo se imaginan la vida familiar del periodista, si bien la visualizan en principio como cualquier otra, expresan una fuerte preocupación por la falta de tiempo para compartir y dedicarse a la misma. La caracterizan también como una familia con miedo a la que es necesario cuidar y no poner en riesgo. Todo esto condicionado al tipo de actividad a la que se dedique.

En cuanto a las expectativas respecto a la Facultad, los ingresantes ya comenzaron un proceso de confrontación con las primeras vivencias y aprendizajes en la misma durante el Curso de Ingreso. Esto permitió recabar sus expresiones respecto a los siguientes aspectos: las referencias previas con las que contaban acerca de la Carrera y de la Facultad antes de ingresar; cómo ellos se imaginaban la Facultad; primeras impresiones que tuvieron de la Facultad en el primer contacto 
con ella; cómo manifiestan sentirse luego de las primeras semanas de experiencia en el Curso.

Las referencias previas con las que contaban acerca de la Carrera y de la Facultad antes de ingresar, son las siguientes: un fuerte peso de lo político, la posibilidad de que les impongan determinadas ideas, desorganizada, caótica, un particular estilo de alumnos "pelos largos", "diferente a otras Facultades". Con relación a cómo ellos se imaginaban la Facultad, creían que iba a ser un ambiente más cerrado, con profesores distantes y aulas grandes.

Respecto de las primeras impresiones que tuvieron de la Facultad en el primer contacto con ella, no se animaron a entrar, desde afuera pasaban y miraban el edificio. En el momento de la inscripción coincidente con los tiempos de elecciones estudiantiles, se sintieron asediados, apabullados por un montón de cosas: carteles, banderas, gente repartiendo panfletos, "todo política, muy politizado". Si bien todo esto les resultaba "caótico", y los asombraba, a muchos también les agradaba.

Cómo manifiestan sentirse luego de las primeras semanas de experiencia en el Curso. Expresan sentirse muy bien, que encontraron un ambiente familiar, donde se pueden expresar sin discriminación, se sienten respetados por los demás, bien tratados, buena integración con el grupo, muy buena relación con los profesores, en un ambiente organizado, etc. Uno de ellos, dice: "como que llegué y...... me estaban esperando". Otro ingresante que había realizado el curso anteriormente y luego abandonó la carrera, comentó que ahora observa un importante progreso en la Facultad, en el edificio, las salas de computación, en los estudios de radio y producción audiovisual, en la organización, etc.

De las dificultades encontradas las más significativas y que los preocupa mucho son las materias que adeudan de la escuela media, en su mayoría del área de ciencias exactas. Algunos señalan también la falta de tiempo para las lecturas por la exigencia propia del ritmo universitario. Entre las molestias que aparecen está la de combinar los horarios de cursadas, las interrupciones de las clases por diferentes distractores y la superposición de actividades propuestas organizadas por distintos espacios de la Facultad (cátedras, Centro de Estudiantes, etc.). De los temores de la vida universitaria presentados en las encuestas, los de ma- 
yor frecuencia son los referidos a situaciones de índole individual tales como: la falta de rendimiento, la posibilidad de fracasar, que el esfuerzo no sea valorado y equivocarse de Carrera.

A los fines de conocer cómo los estudiantes se iban familiarizando con el ámbito de la Facultad, en la encuesta se les propusieron distintos ítems referidos a dónde recurrir en la misma para solucionar problemáticas propias del estudiante. Aparecen con respuesta satisfactoria y con mayor frecuencia las que de alguna manera remiten tanto al Centro de Estudiantes como al Departamento de Alumnos: registrar y actualizar datos personales (354 opciones), buscar bibliografía (288), informarse sobre el Plan de Estudios (264) y conocer horarios de cursadas, fechas de exámenes, etc. (249).

\section{Modos de Relación}

Indagamos en esta dimensión la organización para el estudio y las ideas acerca de los modos, ámbitos y experiencias de aprendizaje, las relaciones con profesores, interacciones grupales, vínculos, movimiento dentro de la institución etc., vivencias que desarrollan en el contexto de la Facultad sumadas a la propia organización para el estudio. En este proceso se conjugan por una parte, lo que brinda y posibilita el espacio académico institucional, y por otra lo que pone en juego el mismo estudiante. En lo referente a la organización para el estudio se exploraron las prácticas habituales. Los entrevistados que explicitan una preferencia sobre horarios para estudiar, expresan que estudian o a la mañana temprano o a la noche tarde.

Del resto algunos adecuan su estudio al tiempo libre entre otras actividades, y otros lo hacen asistemáticamente cuando existe una exigencia de entrega o evaluación. Estos son los tiempos preferidos hasta ahora, pero manifestaron estar reorganizándose en estos horarios, en función del nuevo ritmo que implica la vida universitaria.

Se consultó sobre la relación entre la nota que ellos esperan obtener y la que realmente obtienen. Se observó que la organización para el estudio lleva a una posterior coincidencia entre la expectativa de calificación y la nota lograda, en tanto que la desorganización para el mismo se corresponde con divergencias. 
Existe una gran variedad de espacios seleccionados para estudiar y varios de los entrevistados todavía están buscando ambientar su lugar de estudio, observándose que se lo están planteando con inquietud. La gran mayoría se maneja con las fotocopias, material para estudio propuesto por los Profesores. A pesar de que algunos expresaron dificultades económicas para adquirirlo, todos resolvieron la situación y contaron con los materiales necesarios; se observa un incremento de consumo de bibliografía digitalizada, "cada vez más los textos se leen en la pantalla".

A la pregunta con quién eligen estudiar, responden de la siguiente manera:

- Preferencias para estudiar: En general, no acostumbran utilizar las bibliotecas. Varios no saben con cuáles pueden contar ni dónde están ubicadas. Están muy acostumbrados al uso de internet para estudiar, para buscar información: $57,2 \%$ y para leer diarios: siempre $43,2 \%$, para realizar trabajos con los compañeros: $63,7 \%$

- En cuanto a los procedimientos más habituales para estudiar muchos de ellos subrayan las ideas principales; en algunos casos lo complementan con resúmenes o con otros procedimientos como: marcar términos desconocidos, hacer referencias en el margen de las hojas o al pie, repetir o comentar lo interpretado (especialmente aquellos que estudian con otros). Aparecen situaciones en las que la organización para el estudio se limita a lecturas asistemáticas.

En general en la encuesta manifiestan que el método de estudio les sirve bastante (69\%), mucho (20\%) y poco (11\%). En cuanto a si desearían modificar su método de estudio responden que totalmente (17\%), parcialmente (69\%) y nada (14\%).

Al preguntar qué actividades consideraban facilitadoras del aprendizaje, las que fueron mencionadas se agruparon de la siguiente manera:

- individuales: lectura individual de textos, lectura posterior a una explicación del docente, lectura anterior a la explicación del docente, estudio de apuntes elaborados por otros, resolución de problemas en forma individual, estudio dirigido por el docente con cuestionariosguías, investigaciones y realización de informes. 
- grupales: lectura grupal de textos, resolución de problemas en forma grupal, intercambio de opiniones con otros sobre lo leído, dinámicas grupales y análisis de un texto.

- actividades con fuerte carga vivencial: trabajos de aplicación fuera del aula, participación en talleres donde se pueda crear o producir algo, estudio a través de videos, planificación conjunta con los docentes, visitas guiadas, campamentos educativos, competencias, etc.

- De otra lista de actividades, tenían que marcar si las mismas les resultaban facilitadoras o les dificultaban el aprendizaje. Las elegidas con mayor frecuencia fueron:

\section{De las grupales:}

- intercambio de opiniones con otros sobre lo leído (77 elecciones),

- dinámicas grupales y análisis de un texto (354),

\section{De las vivenciales:}

- participar en talleres donde se pueda crear o producir algo (342),

\section{De las individuales:}

- investigaciones y realización de informes (319).

- La actividad con menor frecuencia, fue estudio de apuntes elaborados por otros (124).

- Las actividades que dificultan el aprendizaje, teniendo en cuenta el nivel de elaboración requerido, se agruparon en básicas, complejas y de elaboración. Las que se mencionan con mayor frecuencia son:

- comparar posiciones de diversos autores (171) - compleja;

- expresar las ideas en forma oral (163), - básica;

- realizar monografías (159), - de elaboración;

- resolver problemas (144), - de elaboración.

Cabe destacar que dos actividades de similar complejidad de elaboración como "comparar posiciones de diversos autores" (171) y "extraer conclusiones personales" (62) obtuvieron una frecuencia de elección muy dispar, por lo cual queda en duda qué entendieron por cada una 
de ellas. También marcaron como dificultosa "expresar las ideas en forma oral", siendo que en las entrevistas manifestaban marcada preferencia por expresarse oralmente.

Lo que rescatan como aprendizaje de la escuela secundaria tiene relación con asignaturas del área de las ciencias sociales, especialmente con profesores en particular y con cuestiones instrumentales como aprender a estudiar, a debatir, a tomar apuntes. Como fue mencionado anteriormente, entre los motivos de elección de la Carrera, en algunos de los ingresantes fue determinante el haber realizado prácticas vinculadas con el periodismo y la comunicación, propiciadas por docentes de sus escuelas secundarias. No mencionan como parte del aprendizaje los aspectos socio-afectivos.

Las diferencias que desearían encontrar en la Facultad respecto a la escuela secundaria son:

- los temas de estudio de interés (237);

- las posibilidades de expresión (194);

- la metodología de enseñanza (155);

- la relación con los profesores (132).

Los temas o problemas de mayor interés que aparecen en las encuestas, se agrupan de la siguiente manera para facilitar su análisis:

- Problemas sociales (marginalidad, derechos humanos, violencia, desocupación, discriminación, salud, sexualidad, familiares, trabajo): 432.

- Temas político-económicos (política, seguridad, economía): 214.

- Estéticos (literatura, música, moda): 187.

- Ciencia y tecnología (ecología, ciencia, tecnología): 135.

- Deportivos: 132.

- Espirituales (religión, místicos, new age, orientalismo): 39.

Las ideas de los ingresantes sobre los modos y ámbitos de aprendizaje fueron problematizadas en dos talleres de reflexión. El objetivo perseguido fue el de aproximarse a ellas y a las representaciones acerca del aprendizaje y las condiciones que lo facilitan de modo de identificar posibles accesos pedagógicos de significación para los sujetos-estudiantes. 
Es decir, reconocer el impacto de las condiciones de escolaridad previa, identificando posibles lugares de conflicto y dificultad y ciertos lugares estratégicos a tener en cuenta en las propuestas pedagógicas de la formación profesional en comunicación. Se consideró importante indagar la conceptualización del aprendizaje, las percepciones y opiniones acerca del aprender en un ámbito escolarizado y fuera de este ámbito.

\section{Caracterización sobre el aprendizaje}

\section{¿Qué es aprender?}

Ante la propuesta de realizar una "lluvia de ideas" que respondiera a esta pregunta, apareció como central que aprender es "adquirir/asimilar conocimientos". Sin embargo, luego de planteada esta perspectiva, casi todo el grupo comienza a revisarla, y diferencian lo que consideran "formación" de lo que sólo implica "información", ya que poder reproducir ésta no significa que se ha aprendido. El aprendizaje es más un "saber que se usa", significa "cambiar" y "crecer". A veces también puede significar un retroceso, porque "el hombre posee conocimientos que no le sirven a la humanidad". Las experiencias vividas propias y ajenas son consideradas una fuente de aprendizaje. El error, el equivocarse también es una manera de aprender.

\section{¿Cómo se aprende?}

En el cómo se aprende se otorga importancia a la actividad del sujeto en el aprendizaje, ya que se aprende investigando, equivocándose, cambiando, imitando, estudiando.

\section{¿Cuáles son las condiciones para aprender?}

En este sentido, las opiniones sostienen fundamentalmente que se aprende aquello que a uno le interesa, cuando tiene una motivación por aprender algo que le llama la atención, lo que despierta curiosidad, lo que se origina en las inquietudes propias, cuando se tiene la posibilidad de elegir aquello que se aprende. 
Se les propuso la consigna de pensar en los aprendizajes que habían tenido que realizar ante la situación nueva de ser estudiantes universitarios por un lado, y en los aprendizajes que habían realizado en el curso de ingreso. El objetivo de esta actividad fue el de actuar como disparadora de la comparación entre los elementos implicados en una situación de aprendizaje no escolarizada y una escolarizada. Entre los aprendizajes que, para ellos, implicó el hecho de comenzar a ser estudiantes universitarios, aparecen con fuerte peso las cuestiones relacionadas con lo afectivo y lo vincular, con el lugar de ellos en una situación nueva, que representó "cambios", "dolor", "adaptación", "crecimiento". Consideran a la vida universitaria una instancia de aprendizaje en la que "se ponen en juego", donde "no está todo dado" como ocurría en la escuela secundaria. Tuvieron que aprender a relacionarse con gente desconocida, dejar a sus familias, asumir nuevas responsabilidades, manejar su vida solos, adaptarse a un nuevo ritmo de estudio. La necesidad, las ganas de hacer lo que les gusta, la búsqueda de integración con los demás parecen ser las razones de estos aprendizajes. Con respecto a cómo los lograron expresan que fue en forma dinámica, con ayuda de amigos y gente que "está en la misma", con el apoyo de los profesores del curso de ingreso, con constancia y responsabilidad, "a los golpes y a fuerza de extrañar".

En cuanto a los aprendizajes realizados en el curso de ingreso, aparecen como centrales, más que contenidos específicos, cuestiones que se vinculan en gran medida con las mencionadas en el párrafo anterior. Señalan al respecto, que aprendieron a formar opiniones propias y a fundamentarlas, nuevas maneras de expresarse y a escuchar las opiniones de los demás, a interpretar y comprender textos, a comunicarse y conocerse, a perder el miedo a la Facultad, a valerse por sí mismos, a preguntar, a buscar. Sostienen que esto lo aprendieron trabajando en grupos, "didácticamente", observando los roles, debatiendo. Lo aprendieron porque les interesó, mediante la propuesta de trabajo de los talleres y la discusión. Valoran como muy positiva la experiencia del Curso de Ingreso y están a la expectativa de ver cómo seguirá el proceso en el primer año de la Carrera. 


\section{Percepción sobre Educación:}

- Primera Carrera universitaria; si el 66,3\%.

- ¿Cuándo termines este nivel pensás seguir estudiando? Si el 49,5\%,

\section{Sentido de la educación:}

- Me permite ser independiente de acuerdo el 70,1\%.

- Me da herramientas para el futuro: de acuerdo 93,5\%.

- Nos convierte en hombres y mujeres libres, de acuerdo 63,2\%.

- Dignifica a las personas lo afirman 53,6\%.

\section{Prácticas Comunicacionales Cotidianas}

Preguntamos sobre los modos de recepción-consumo y los distintos usos que hacen los jóvenes en torno a las prácticas de comunicación cotidianas, el uso de los medios de comunicación y las nuevas tecnologías, no podemos dejar de prestar atención a las tramas sociales y culturales que los habitan: la clase, el género, la edad (pero también los espacios donde consumen los productos mediáticos y las formas en que resignifican esos consumos) para poder entender la complejidad de la/s situación/es concretas en las que se produce la relación entre los sujetos y los medios.

La mediatización implica el trabajo de instituciones, grupos y tecnologías, por eso resulta necesario, también, considerar en el análisis las múltiples mediaciones en que esas relaciones están inscriptas. Desde la perspectiva de la recepción, entendemos la noción de "mediación" de la mano de la propuesta conceptual de Guillermo Orozco Gómez, quien estudia los modos de interactuar con los consumos simbólicos a partir de mirar las "múltiples mediaciones" que atraviesan a los sujetos. Esas múltiples mediaciones suelen ser de distintos órdenes, de acuerdo con lo que consigna el autor de referencia:

- mediación cognoscitiva: alude a aquellos guiones mentales que son actualizados por los sujetos, a través de una esfera de significación; refiere a la prescripción de formas adecuadas, culturalmente aceptadas; 
- mediación situacional: hace referencia a la situación concreta en la que, por ejemplo, se ve televisión, se navega por internet o se escucha un programa de radio. Tiene especialmente en cuenta las situaciones, instituciones y agentes involucrados en esa instancia particular;

- mediación institucional: hace referencia a la participación de los sujetos en diferentes instituciones con sus propias esferas de significación (escuela, familia, trabajo, club social y/o deportivo, partido político, etc.);

- mediación de referencia: implica ver que en el proceso de recepción entran en juego referentes que se constituyen en mediación (grupo de pares por género, etnia, edad, origen social o geográfico, etc.).

Las mediaciones son entendidas como aquellas instancias estructurantes de la interacción de los sujetos con los medios y las tecnologías. Configuran la "negociación" que las personas realizan entre los valores, prácticas y creencias propias con los valores y creencias inscriptos en los productos y mensajes que reciben a través de los medios. En el caso de los jóvenes que estamos analizando, las mediaciones que tenemos particularmente en cuenta son las que enunciamos más arriba respecto de sus tramas sociales y culturales (Orozco Gómez las entiende como "mediaciones de referencia"), además de las mediaciones institucionales en las que están inscriptos: la inscripción educativa (especialmente la universidad); el grupo de pares - otros estudiantes, los/as amigos/as-; la inscripción familiar, así como también las posibilidades reales de acceso y usos concretos de los medios y tecnologías. Se preguntó sobre los modos, las producciones comunicacionales y culturales de los alumnos ingresantes: en el día a día, el medio con el cual se relacionan, los intereses y actitudes en carácter de receptor/consumido, de comunicador. La mayoría de ellos son ingresantes a la carrera, de modo que sus consumos culturales aún no están atravesados por la experiencia universitaria. "Sin embargo son jóvenes cuyas identidades se trazan en la intersección del texto escrito, la imagen electrónica y la cultura popular en tanto "cultura audiovisual y mediática en general". "Si las identidades de los jóvenes se definen no sólo en el libro que leen, sino, y fundamentalmente, en los programas de televisión que miran, en el contexto multimedia por el que navegan, en la música que escuchan y en la película que eligen, 
será necesario analizar la manera en que los jóvenes se relacionan con los bienes culturales" 58 .

En las encuestas, con referencia a las prácticas comunicacionales se propuso una amplia gama de actividades a modo de opciones, que a los fines del análisis se las agrupó en dos grandes categorías: actividades que se relacionan con la producción y actividades de consumo.

- Producción: escribir ensayos, pensamientos y sentimientos, poemas, canciones, cuentos o relatos; sacar fotos; producir videos; hacer música; participar en organizaciones o grupos.

- Consumo: leer textos literarios (ciencia ficción, cuentos, relatos, novelas, poemas) y textos periodísticos (investigaciones periodísticas, diarios, historietas, revistas científico-tecnológicas, de moda y espectáculos, de actualidad y política), ver videos, TV, cine, utilizar computadora, netbook o tablet para comunicarse, escuchar radio y música, participar en programas de radio, utilizar videojuegos.

Se registraron 930 opciones relacionadas con actividades de producción (lo que significa un bajo porcentaje si se tiene en cuenta la cantidad de opciones y las posibilidades de marcarlas sin límite alguno); en tanto que en actividades de consumo, de un total de 2963 opciones, 1069 se refieren a lecturas periodísticas, 707 a consumo radiofónico y musical, 559 se refieren a lecturas literarias, 556 a consumo audiovisual y 72 al consumo de programas interactivos.

De las entrevistas realizadas y analizando la agenda cotidiana y sus contactos con los medios, se observa que la gran mayoría se vincula con la radio en distintos momentos del día, siendo la mañana y la noche los horarios de mayor recepción. Los programas más escuchados por orden de preferencia son musicales (241 opciones), informativos, noticieros (148 opciones), deportivos (136 opciones), culturales-sociales (70 opciones), sobre todo en FM. Este medio representa una compañía para el estudio y para el entretenimiento.

En cuanto a la televisión manifiestan que no les gusta mucho, que miran poco, lo hacen sobre todo en horarios del mediodía y nocturnos. 
La oferta televisiva más consumida son programas informativos noticieros (175 opciones), películas (140), deportivos (132), musicales y videoclips (97) de investigación periodística, o hacen zapping.

Ambos medios, radio y TV, aglutinan el mismo tipo de interés coincidiendo con la selección del área laboral deseada en la que prevaleció el periodismo cultural (132 casos), político (128) y deportivo (128). Los diarios son de lectura más frecuente para los estudiantes que conviven con sus familias, para los del interior representan un costo adicional, motivo por el cual el acceso es limitado. Leen sobre todo titulares, policiales, noticias de interés nacional e internacional, espectáculos. El cine aparece como un medio de interés, también limitado por factores económicos. Enuncian poco uso del video. En cuanto a las revistas hay muy poco consumo.

Tal como hemos dicho, los procesos de producción de sentidos que despliegan los sujetos en su relación con los medios y las tecnologías en el marco de múltiples y diversas mediaciones, inscriptos en una sociedad eminentemente mediatizada. Sentidos que no pueden ser analizados desde el modelo clásico "emisor-mensaje-receptor", como un intercambio de mensajes que producen determinados efectos, sino que requieren ser comprendidos desde la perspectiva de la interacción simbólica, en tanto proceso complejo que involucra tanto a la producción como a la circulación, el consumo y la resignificación de las formas simbólicas en contextos determinados. Los procesos comunicacionales en los que los sujetos intervienen están dados por el renovar, el repetir y el reproducir constante; de esta manera las prácticas sociales fortalecen la trama cultural. Estas prácticas, al ser analizadas desde la mirada comunicacional, son leídas como enunciaciones que producen los sujetos sociales (pronunciamiento sobre la forma en cómo miro en la tele, para qué uso internet, cómo me comunico con los demás). Al elegir "mirar desde la comunicación", se pretende entender el mundo en que vivimos mediante interpretaciones, desde la lógica de la producción y la lucha por los sentidos, ese es el lugar de entrada para interpretar las prácticas históricas de los sujetos sociales, en este caso las prácticas culturales de los sectores juveniles y sus modos de relacionarse con los medios. Las enunciaciones de los jóvenes y su interacción con diversas modalidades 
de comunicación sólo es posible anclarlas y comprenderlas en el contexto de mediatización de la cultura o "cultura mediática". Una cultura y una sociedad que es constantemente reconstruida, relatada y resignificada en y a través de los medios y las tecnologías de información y comunicación. En el ámbito de las ciudades y cada vez más en las áreas menos pobladas, pareciera que es imposible realizar un sinnúmero de actividades cotidianas sin la presencia de las tecnologías en un marco donde, además, lo electrónico ha ido dándole paso a lo tecnológico y lo analógico a lo digital.

A medida que los textos mediáticos circulan, nosotros, los sujetos, también contribuimos a su producción. Nuestro tránsito diario implica movimientos a través de diferentes espacios mediáticos, dentro y fuera de ellos. Los medios de comunicación nos ofrecen estructuras cotidianas, puntos de referencia para unirnos y oportunidades para desunirnos (Relacionarnos con los medios y las tecnologías en la vida cotidiana nos posibilita relacionamos con otros mundos, atravesar otros "umbrales", el de los demás, el de los otros conocimientos y saberes, lejanos o cercanos. Y esa experiencia, dice Silverstone, "experiencia mediatizada y mediática", se expresa, desde luego, en lo social y en los discursos, en la conversación y las historias de vida cotidianas, donde lo social se reproduce constantemente. Al realizar estas proposiciones tenemos en cuenta las denominadas "brechas digitales, culturales y económicas", reconocemos la imposibilidad de acceso a los bienes simbólicos y tecnológicos de miles de ciudadanos en el mundo e incluso de los estudiantes ingresantes a la carrera de Periodismo y Comunicación Social.

En prácticas culturales aparece una gran variedad de actividades relacionadas con: la música (el mayor motivo es para escuchar y disfrutar, otros tocan distintos instrumentos), el gusto por la lectura, y en otros casos por la lectura y la escritura (los motivos: "distenderse", como "espacio íntimo", para "disfrutar sin obligaciones"). Otras actividades que aparecen son: ir a bailar y jugar al fútbol. La actividad más significativa está centrada en compartir tiempo con los amigos, reuniéndose en casas, saliendo en grupo y sobre todo, "para charlar y estar juntos", sentirse acompañados. 


\section{Sobre consumos culturales ${ }^{59}$}

"En el lenguaje ordinario, consumir suele asociarse a compulsiones irracionales y gastos inútiles" ${ }^{10}$ reflexiona al tiempo que se pregunta sobre la importancia que tiene para los sujetos adquirir ciertos bienes simbólicos, usar y apropiarse de determinados productos. El autor encuentra una serie de modelos teóricos para plantear el consumo a partir de dos críticas fundamentales: la concepción naturalista de las necesidades (que habla de "necesidades naturales" de los humanos) y la concepción instrumentalista de los bienes (donde pareciera que los bienes son producidos sólo para satisfacer esas necesidades naturales). Esta propuesta incluye cinco criterios para pensar el consumo desde su complejidad, desde diversas racionalidades:

- racionalidad del deseo: partiendo de la idea de sujeto incompleto trabajado desde el psicoanálisis- que se mueve motivado por la búsqueda de la completud;

- racionalidad económica: permite pensar el consumo como un momento del ciclo de producción y reproducción social;

- racionalidad sociopolítica interactiva: desde esta perspectiva, se pasa de ver al consumo como un lugar de imposiciones verticales a entenderlo como un espacio de interacción, donde las personas se enfrentan por lo que la sociedad produce y por sus maneras de usar esos productos;

- racionalidad simbólica y estética: el consumo aparece así como un lugar fundamental para la construcción de signos de estatus y para su comunicación, como un lugar para la distinción, a través del cual se construye un "nosotros" y un "los otros";

- racionalidad integrativa y comunicativa: entendiendo que no existe un mero enfrentamiento entre aquel "nosotros y los otros", sino que en el consumo se comparten los sentidos de los bienes porque tanto para la integración como para la distinción se produce un intercambio de significados

59 Encuesta sobre Jóvenes ingresantes a la Facultad de Periodismo y Comunicación Social. Elaborada por el Observatorio de Jóvenes medios y comunicación. FPCS UNLP Marzo 2011. 


\section{La televisión que miran}

La pregunta de la encuesta en este caso fue abierta lo que a priori dificulta la sistematización de los datos para este análisis: "Programas de televisión que mirás" fue la categoría y por eso a posteriori se han establecido siete géneros (algunos mencionados por los alumnos en sus encuestas): deportes, novelas, noticieros, periodísticos, periodísticos de humor, ficción humorística y series americanas. Un aspecto a tener en cuenta es que en este caso, cuando indagamos sobre sus consumos televisivos, las respuestas fueron múltiples. No se mira un solo programa de televisión. A veces ni siquiera se mira un programa entero, sino que la recepción televisiva está marcada por el zapping constante, de modo que cada joven refirió, en general, más de un programa/género. En los resultados de la encuesta veremos cómo se vislumbran diferencias y puntos de encuentro entre los consumos de los chicos y el de las chicas. En el primer caso se muestra quizá la persistencia del cliché con el que se arma la grilla de programación televisiva. Los/as alumnos/as son hombres y mujeres y cada uno mira aquello que fue pensado, armado y puesto al aire para hombres y mujeres respectivamente. Si bien no se preguntó si miran televisión solos o acompañados y en ese caso con quién, y por eso tampoco sabemos si tienen televisión propia, o compartida y si eligen/ deben ver juntos, las mujeres en un $80 \%$ eligen novelas y un $60 \%$ de los hombres programas deportivos. Sobre la programación de humor donde los porcentajes se acercan, e incluso los programas mencionados son los mismos. Pues en el caso de los periodísticos ellas suman un $70 \%$ y ellos un $60 \%$, pero en cada caso, además, podríamos interpretar que hay una fuga de la televisión a la web donde los videos del programa se reproducen miles de veces. Es en internet donde se ve, también, televisión. Los viejos y nuevos medios no sólo coexisten en la práctica y experiencia cotidiana de los jóvenes sino que los nuevos modifican las pautas de consumo instalando nuevas formas de ver.

\section{¿Cuántos televisores hay en tu casa?}

- Uno: $35,5 \%$

- Ninguno 6,1\%

- Lugares donde están los televisores: espacios compartidos 62, 3\% 
¿Qué tipos de programación miran los jóvenes?

\begin{tabular}{|l|r|r|}
\hline \multicolumn{1}{|c|}{ PROGRAMA } & \multicolumn{1}{c|}{ SIEMPRE } & \multicolumn{1}{c|}{ A VECES } \\
\hline Infantiles & $12,1 \% ;$ & $43,6 \% ;$ \\
\hline Películas & $37,6 \%$ & $96,6 \%$ \\
\hline Novelas & $21,3 \%$, & $63,2 \%$, \\
\hline Noticieros & $51,9 \%$, & $96,9 \%$ \\
\hline Reality Shows & $16,6 \%$, & $63,5 \%$, \\
\hline Series & $36,6 \%$, & $83,4 \%$ \\
\hline Musicales & $23,2 \%$, & $68,9 \%$ \\
\hline Deportes & $59,9 \%$, & $82,8 \%$, \\
\hline Documentales & $24,2 \%$, & $81,8 \%$ \\
\hline Programas sobre Política & $16,8 \%$, & $62,4 \%$, \\
\hline
\end{tabular}

\section{El cine}

La experiencia de ir al cine pareciera estar en crisis así como la práctica de alquilar películas en vías de extinción: el cierre de salas en el interior del país, su reubicación en grandes complejos ubicados en los shoppings en Capital Federal, el cierre de los videoclubs de barrio, son algunos ejemplos de este fenómeno. Todos los estudiantes en un $70 \%$ alquilan películas y la mitad va al cine; de modo que su cultura audiovisual no sólo implica que ven películas sino que en gran parte aún las ven como tradicionalmente hicieron sus padres. Pero además estas viejas prácticas se yuxtaponen con aquellas vinculadas a las nuevas posibilidades que ofrecen las nuevas tecnologías: se compran películas "truchas" (es decir, bajadas de internet o grabadas del original); respecto de bajar películas los varones alcanzan el $40 \%$ y las mujeres el $30 \%$. Evidenciamos en este punto lo mismo que en la interrelación televisión-internet. Los avances tecnológicos se insertan en sociedades históricamente constituidas y son usadas por sujetos históricamente situados de modo que los usos de esas tecnologías no son de una vez y para siempre. Por eso mucho antes de la televisión por cable y de internet, ya el VHS había cambiado la forma de ver películas. "Las interrelaciones específicas entre una tec- 
nología y sus condiciones económicas y sociales producen resultados determinados por la naturaleza de la tecnología como tal, pero también pueden contradecirla en los usos que les da cada sociedad en un momento determinado"61. ¿Y qué géneros eligen? Aquí no hay sorpresas. Los estudiantes eligen, de acuerdo con el género al que representan, aquellos productos que el mercado elabora de manera estandarizada: Los varones prefieren el suspenso (40\%), drama (20\%) y terror (10\%). Las mujeres, en cambio, eligen mayoritariamente comedia (40\%) y aclaran, particularmente, que refieren a la comedia romántica. Además miran drama (30\%) y suspenso (30\%). Por otra parte, hay que destacar que los y las estudiantes suelen frecuentar las salas de cine pero, cada vez más, compran películas "truchas" o las bajan o visualizan de manera on line, a través de diversas plataformas especializadas disponibles en internet

Más allá de los parámetros de legalidad sobre la propiedad intelectual, este tipo de consumo podría situarse en lo que García Canclini denomina "sociopolítico interactivo", se constituye como práctica de democratización de la producción cultural: el mercado ofrece ciertos productos pero los sujetos se niegan a pagar un alto costo económico por ellos; consecuentemente, los sujetos elaboran estrategias para poder adquirirlos sin necesidad de abonarlos, pero con el plus de que no sólo se los consume de manera individual sino que se coloca ese producto a disposición de quien desee consumirlo de igual manera.

\section{Los usos de internet en los estudiantes}

Respecto de los usos de internet, la encuesta le da a los/as jóvenes estudiantes las siguientes opciones para que elijan la que coincide con sus rutinas: "informarte"; "bajar información”; "bajar música”; "otro (explicar)". Esta última les permite agregar alternativas que no aparecen en el cuestionario. El 90\% de las estudiantes manifiesta que utiliza el recurso de internet para mantenerse informada; en relación con los varones, el 100\% de ellos completa la encuesta señalando, también, que el mayor uso que hacen de la red es para "informarme", estas respuestas nos hacen preguntarnos ¿internet se convierte en la medida de todas

61 WILLIAMS, Raymond, Historia de la Comunicación, volumen 2, Madrid: Bosch Comunicación, 1981. 
las cosas? ¿Es la nueva gran biblioteca de Alejandría para los actuales sectores juveniles universitarios?

Asimismo, el $70 \%$ de las chicas y el $90 \%$ de los varones reconocen que "baja" información de la red para estudiar, de modo que es posible pensar que el uso de la tecnología habla de que con este tipo de prácticas se están produciendo transformaciones en los modos de acceder y producir la información y el conocimiento.

En tal sentido, la investigadora mexicana Rosalía Winocur sostiene que "hay que reconocer que, la universidad pública, independientemente del origen socio-cultural de los jóvenes, constituye un ámbito privilegiado de socialización informática vinculado no sólo a las exigencias curriculares sino también a la cultura universitaria".62 En consecuencia, el dato que nos proporciona la encuesta, abre una serie de preguntas ¿de qué manera los jóvenes gestionan la información que buscan/encuentran en internet? ¿Qué estrategias es posible desplegar, desde el rol docente, para colaborar en la gestión de esa información y que sea significativa para el proceso de enseñanza-aprendizaje? Bajar música es otro de los usos de internet expresado por las chicas y los chicos, pero esta elección aparece señalada en menor proporción que las anteriores respuestas sobre usos de la red. En la opción "Otro", dos de las entrevistadas manifiestan que emplea internet para actualizar sus blogs y fotolog y otra estudiante agrega la acción de chatear (para poder pensar internet en tanto socialización, interacción con otros).

En la opción "otros usos" aplicada a los varones, la encuesta arroja el siguiente resultado en esta muestra: un estudiante señala el uso de redes sociales y el canal de videos You Tube; otro enfatiza que utiliza internet para "pasar el tiempo y comunicarme con amigos"; y un último encuestado dice que hace uso de la red para "chatear y jugar".

La habilidad de los jóvenes de relacionarse y hacer diversos usos de las tecnologías tiene como precondición la habilidad de conocer el potencial de esa tecnología, de manejar su lenguaje y sus códigos, esto es aprehender el sentido de la tecnología como habilidad. En este marco, 
pareciera que varones y mujeres ponen en juego diferentes habilidades en cuanto a las prácticas y usos diversos que manifiestan.

Desde las respuestas a la encuesta es posible inferir que las mujeres adoptan una actitud "operativa": prefieren escribir en los blogs, mostrarse en el fotolog, y conversar con amigas a través del chat, usar la red como espacio de expresión y creación. En cambio, los varones, parecieran modular una actitud más bien "ociosa" gustan más de mirar videos y jugar, de usar la red como entretenimiento y recreación. No obstante, hay que destacar que dos de ellos indican el uso de la red social Facebook, el primero agrega el uso del buscador "Google para (hacer) consultas en general".

Observamos que mayoritariamente los jóvenes afirman utilizar la red para informarse. Se da una yuxtaposición de diferentes medios de comunicación, es decir, las tecnologías se suman, se combinan y se alternan, pero no siempre nuevos medios implican la muerte de los viejos medios. Los jóvenes se informan por internet pero también por televisión. Un 70\% de las mujeres encuestadas afirma mirar algún programa periodístico o noticiero mientras que en los hombres el porcentaje se reduce a un $30 \%$. La duda que se impone es si acaso esa diversidad de medios implica diversidad de puntos de vista, o si en internet y en televisión, leen y miran medios de un mismo grupo mediático.

- ¿Tenés computadora donde vivís? Si 93\%

- ¿Quienes usan esa computadora? Solo yo 38,8\% Varias personas 99,8\%

- ¿Tenés conexión a Internet? 91,1\%

- ¿Qué actividades realizan los jóvenes en Internet?

- Actividad en Internet:

\begin{tabular}{|l|r|r|}
\hline \multicolumn{1}{|c|}{ ACTIVIDAD } & SIEMPRE & A VECES \\
\hline Buscar información & $57,2 \% ;$ & $99,4 \% ;$ \\
\hline Leer diarios & $43,2 \%$ & $90,1 \%$ \\
\hline Trabajar & $18,6 \%$, & $54,7 \%$, \\
\hline Conocer gente & $28,1 \%$, & $69,1 \%$ \\
\hline Chatear con amigos & $71,9 \%$, & $98,6 \%$, \\
\hline
\end{tabular}


Con respecto a los usos del correo electrónico, el cuestionario suministrado a los/las estudiantes presenta las siguientes opciones de respuestas: "Comunicarme con amigos"; "Trabajo"; "Archivar información” y "Otro". Veamos cuáles han sido las respuestas.

El cien por cien de las mujeres reconoce que usa la cuenta de e-mail para comunicarse con amigos, en primer lugar. La tecnología posibilita encontrarse con los amigos y amigas, organizar salidas, compartir música, fotos, saber cómo están y contarles las últimas novedades sin necesidad de salir del hogar. El e-mail (también el mensaje de texto) ha ido desplazando al crédito del teléfono -tal vez por lo costoso que resultan las comunicaciones- como dispositivo de la conversación mediada con los amigos.

En segundo término aparece la opción "archivar información", si bien la encuesta no busca indagar qué tipo de información es la que se archiva, deducimos que seguramente alude a datos (documentos, fotos, música o links) que envían los/as amigos/as y que se considera necesario guardar en la casilla privada y no en la PC. Así como nuestra generación -y las anteriores- archivábamos en cajas de cartón las cartas y tarjetas que nos enviaban nuestros seres queridos desde lejos, pareciera que para las nuevas generaciones la casilla de correo electrónico, a la que se accede por medio de una clave secreta y personal, se convierte en el cofre de seguridad donde acumular la información considerada importante; por necesidad o por rutina los mails se van clasificando y acumulando ¿para ser consultados y reenviados alguna vez?

En cuanto el uso del correo electrónico en los varones, un 100\% de ellos ofrece como respuesta que lo utiliza para la comunicación con los amigos (lo mismo que sucede con las chicas) y el $80 \%$ que emplea la cuenta de e-mail para "archivar información". Sólo un estudiante expresa que lo tiene en cuenta para su trabajo (se desempeña en la fotocopiadora de la Facultad de Derecho). "Todas las experiencias son reales, aun las mediáticas ${ }^{63}$; esto nos permite explicar por qué en el ítem "otros usos" un estudiante revela que emplea la casilla de correo para comunicarse con sus familiares, ya que es oriundo de Henderson, provincia de Buenos 
Aires y el email le posibilita la experiencia de estar cerca de la familia aun a seiscientos kilómetros de distancia.

Las tecnologías nos proveen, en un grado importante, tanto de herramientas como de conceptos y categorías para construir y sostener las conexiones cotidianas, construir y defender las distancias que nos separan de los afectos, la información y los saberes...

En medio de estos procesos es posible identificar aquellas mediaciones que permiten recrear los sentidos y significados, dado que la interacción que se produce con los medios está inscripta por los sentidos recreados en (y por) otras instancias sociales (la familia, el trabajo, la universidad, los amigos).

\section{Afirmaciones sobre el acontecimiento}

Refiriéndose a los jóvenes estudiantes de comunicación, Jesús Martín Barbero, dedicado al estudio de la cultura y la comunicación señaló: "Los estudiantes atraviesan hoy una crisis muy particular que se produce en el cruce de la desaparición de la utopía de las izquierdas con la crisis laboral de nuestros países. Nos queda muy fácil a los adultos decir que la juventud actual es una juventud conformista, artificial, que casi no lee, que quieren que le den las cosas hechas y no es que no haya bastante de eso. Pero yo pienso que además de eso, y explicándolo, está la caída del Muro de Berlín, la desfiguración, casi la desaparición de un discurso capaz de galvanizar las energías de la gente joven desde una utopía social; y hay por otro lado una enorme zozobra por el futuro: ¿Qué vamos a hacer en países en los que la división social se acrecienta, en los que el desempleo se acrecienta?

En la actualidad hay más de 350 escuelas de comunicación en América Latina, esto nos constituye en la región del planeta con más establecimientos de este tipo, sobre todo en el Tercer Mundo. Este fenómeno nos podría llamar a pensar en un proyecto común, histórico, para perfeccionar la comunicación social. Podría pensarse que en nuestro medio los problemas comunicacionales han sido solucionados en su mayor parte por los miles de egresados que están promoviendo la comunicación en cada uno de los puntos del tejido social; que vivimos un diálogo cons- 
tante entre los distintos sectores de la sociedad que utilizan recursos comunicacionales. Pero la cantidad no ha estado ni está en relación con el progreso de lo comunicacional en nuestra sociedad"64.

Esto último puede corroborarse fácilmente si se medita sobre el alcance del concepto mismo de comunicación. "Cuando se piensa que este corresponde a muy complejos y muy variados elementos del sistema social, como las relaciones interpersonales, la educación, las distintas instancias públicas, la burocracia, las instituciones a su interior y entre sí, uno concluye que este tema tiene un alcance inmenso, que por muchas escuelas que se funden nunca habría la suficiente cantidad de gente egresada, ni la suficiente capacidad como para abarcar y solucionar todos los problemas que plantea la comunicación."

El sistema educativo, como área estratégica de investigación y acción, aparece de manera necesaria como una de las primeras prioridades en el horizonte formativo de las Facultades de Comunicación. Hasta ahora, podríamos decir que se ha desandado la mitad del camino, al relacionar procesos de comunicación con transformaciones culturales. El desafío pendiente, entonces, pasa por relacionar comunicación y cultura con transformaciones en la educación. Lo primero está en plantear que antes que una cuestión de medios, el escenario comunicativo que tenemos hoy, es una cuestión de fines. No se suele poner en relación esto, se habla de medios, se piensa en instrumentos, pero no se relaciona a los medios con los fines. Y mucha de la teoría de comunicación que estamos explicando y enseñando toma a los medios como si fueran fines. Fines en términos ideológicos, en términos culturales. Es decir, la pregunta de fondo que nos tenemos que hacer las escuelas de comunicación: ¿qué transformaciones necesita la Universidad para encontrarse con su sociedad?, ¿cuáles necesita el sistema escolar, de la primaria hasta la universitaria para encontrarse con su sociedad, con la complejidad, la ambigüedad?

Partiendo de que la comunicación es sólo una cuestión de fines y no de medios, podemos pasar a hablar de que hoy la Universidad ha- 
bita un ecosistema comunicativo. Este ecosistema es, a la vez, entorno e informaciones, cual un espacio educativo pero difuso y descentrado (todo lo contrario de la Escuela, que es un espacio educativo, unificado y concentrado). Hay ahora un sistema educativo difuso y descentrado, esto significa que los acostumbrados agentes del saber quizás ya no lo seamos más.

Son los medios los que están descentrando el saber, los que están sustituyendo a los popes del saber, mostrando que se puede hacer saber, que se puede compartir saber, sin necesidad de haber pasado por Harvard" 65 En esta sociedad el saber tiene un nuevo estatuto, lo costoso es el conocimiento y no la materia prima, no lo que hacen las máquinas. Entonces, por aquí pasa algo fundamental. Tenemos que sacar el problema del ámbito de la tecnología educativa, es de otro calibre el asunto. No son sólo tecnologías de comunicación, son tecnologías de producción de conocimiento. En este sentido, el riesgo es reducir la información a la información periodística; hay diversos tipos de información y una inmensa parte de esa mayoría de información es saber, inclusive saber científico. Mucho del autoritarismo de los docentes, es porque estamos ante unos alumnos que saben más que nosotros, no saben lo que sabemos los docentes, pero saben más que nosotros, de matemática, de geografía, de química. Aprendido a través de enciclopedias que se compran por fascículos, de programas de tv, montones de información que está ahí flotando.

Lo que plantea este ecosistema comunicativo, que es a la vez, entorno informacional, comunicacional difuso y descentrado, es que ese ecosistema es también una experiencia cultural. Es otro modo de percibir, otro modo de sentir, de experimentar la velocidad.

Reafirmamos la idea de ecosistema educativo y tomando palabras de Martín Barbero, "entraña ante todo un reto cultural", porque la tecnicidad mediática es una dimensión estratégica de esa cultura. "Sólo asumiéndola como dimensión de la cultura, no como instrumento, como un artefacto; sino como una dimensión central de nuestra cultura actual vamos a poder interactuar con los campos de experiencia en que hoy 
se procesan los cambios: la desterritorialización de las identidades mundiales, su desanclaje, los movimientos de localización, las hibridaciones entre ciencia y arte (considerándolas un nuevo campo expresivo, entre oralidades, escrituras y audiovisuales). Los humanos estamos enamorados de nuestras herramientas porque nos ayudan a vencer limitaciones y a reducir los obstáculos que impiden un mejor uso de nuestras ideas y de nuestros cuerpos. Podemos concebir desafíos físicos y mentales para los que nuestras dotes naturales son inadecuadas"66; pero tenemos destreza para inventar herramientas que posibilitan la reducción de las limitaciones que nos impiden alcanzar nuestras metas.

Nombrada como "massmediatización" de la sociedad67, en la que los sujetos pueden vivir un estado de conectividad permanente a través de un nuevo sistema de objetos "nómades", que permiten la ubicuidad de la intervención mediática. Como consecuencia de este estado de hiperconectividad, destaca la confusión respecto de los géneros de información que circulan en la red, la aparición de los prosumidores (un concepto que hace alusión a la simultaneidad de actividades productivas y de consumo), las transformaciones en la concepción de intimidad y la creación de nuevas formas de comunidad, de estar juntos a través de las redes. Respecto de los usos de la tecnología, puntualmente sobre las posibilidades que ofrece internet, un dato significativo es que lo eligen para mantenerse informados/as.

Pero también fue indicado como "la" herramienta que permite la apertura de múltiples umbrales, de diversas actividades: conectarse con los amigos, la familia y los docentes, estudiar, escuchar música, archivar y compartir información, buscar trabajo y pasar el tiempo. Los datos que concluimos mediante las encuestas nos confirman que las nuevas tecnologías, de la mano de internet, transforman el sentido del tiempo y el espacio social y cultural de los/as jóvenes; el acceso inmediato a la web $y$ a todo el universo de posibilidades que ofrece, abre nuevas formas de

66 MARTIN BARBERO, Op cit.

67 URRESTI, Marcelo URRESTI, Marcelo (2005), "Adolescentes, consumos culturales y usos de la ciudad”. (En línea).

Ponencia. Seminario Internacional "La escuela media hoy. Desafíos, debates, perspectivas", 5 al 8 de abril. Buenos Aires: Ministerio de Educación/OEl. Recuperado: 16/03/11 de http://oei.org.ar/edumedia/pdfs/T01_Docu3_Adolescentesconsumosculturales_Urresti.pdf 
interconectividad e interactividad -virtual pero no por ello menos real-, nuevas prácticas en el mundo del comercio, la educación, el trabajo, el entretenimiento y la sociabilidad en general, permitiendo concentrar los espacios, acortar las distancias y acelerar los tiempos. El consumo es una práctica cargada de un universo de sentidos, los estudiantes, que siempre están al frente, son -una vez más- los protagonistas absolutos de estas transformaciones. Porque nacieron en un mundo mediatizado, crecieron con las tecnologías y por eso se dice que son "nativos digitales", a diferencia de las generaciones anteriores (sus padres, sus profesores) que se mueven en este mundo como "inmigrantes digitales". Se vuelve necesario y urgente conocer, reconocer y estudiar sus prácticas, para poder comprenderlas y mediar nuestra intervención cuando enseñamos y aprendemos con ellos/ellas. No podemos dejar de considerar que las tecnologías constituyen, además, un producto del mercado, que es el mercado el que interpela permanente y cotidianamente a los jóvenes a usar lo que se produce, pero en definitiva son ellos quienes definen diversas apropiaciones, múltiples modalidades y distintos sentidos del uso. Usuarios, consumidores y prosumidores. Cibernautas, blogueros o hackers, son navegantes creativos de un espacio planteado en red, en inter-acción.

Hace más de diez años Roger Silverstone se preguntaba si en el nuevo ambiente mediático creado y recreado por las tecnologías, existía la esperanza de que, a partir de los improbables comienzos de la anarquía interactiva que es internet en su situación, aun relativamente libre, surgieran nuevas formas de política receptiva y participativa que sean pertinentes tanto para la comunidad global como para la local.

Los hechos de Egipto ${ }^{68}$ son escenas que se precipitan sobre ese pronóstico, escenas protagonizadas fundamentalmente por los jóvenes, quienes motivaron la movilización popular, a través de las diversas convocatorias en las redes sociales (Facebook, Twitter y You Tube) y materializaron su participación congregándose y exponiendo los cuerpos en la plaza, lidiando contra las balas del ejército represor y luchando contra 
el poder cosificado por una sociedad más democrática para todos. Estas experiencias marcan el pulso de nuevas (y más nuevas) formas de la política viabilizadas en la web.

Confirmando que "Las particularidades de los jóvenes hoy radican en la relación que tienen con los medios de comunicación y las tecnologías"69 sostenemos que los estudiantes de comunicación, son hablantes nativos del lenguaje de las computadoras, los videojuegos e Internet y que para nosotros, los inmigrantes, no nativos, lo digital es una segunda lengua. Lo podemos observar en todo lo que hacemos es un acento que matiza todas nuestras actividades y que se refleja fundamentalmente en nuestra vida académica y profesional. "Vamos a Internet cuando no encontramos un libro que previamente dé cuenta del problema"70.

De ahí la importancia estratégica que cobra hoy una universidad capaz de un uso creativo y crítico de las tecnologías digitales de información. Pero ello sólo será posible en una universidad que transforme su modelo (y su praxis) de comunicación, esto es "que haga posible el tránsito de un modelo centrado en la secuencia lineal -que encadena unidireccionalmente grados, edades y paquetes de conocimiento- a otro descentrado y plural, cuya clave es el "encuentro" del palimpsesto y el hipertexto. Como antes afirmamos el palimpsesto es ese texto en el que un pasado borrado emerge tenazmente, aunque borroso, en las entrelíneas que escriben el presente; y el hipertexto es una escritura no secuencial, un montaje de conexiones en red que, al permitir/exigir una multiplicidad de recorridos, transforma la lectura en escritura. Mientras el tejido del palimpsesto nos pone en contacto con la memoria, con la pluralidad de tiempos que carga, que acumula todo texto, el hipertexto remite a la enciclopedia, a las posibilidades presentes de intertextualidad e intermedialidad. Doble e imbricado movimiento que nos está exigiendo sustituir el lamento moralista por un proyecto ético: el del fortalecimiento de la conciencia histórica, única posibilidad de una memoria que no sea mera moda retro ni evasión a las complejidades del presente. Sólo asu- 
miendo la tecnicidad mediática como dimensión estratégica de la cultura es que la escuela puede hoy interesar a la juventud e interactuar con los campos de experiencia que se procesan esos cambios: desterritorialización / relocalización de las identidades, hibridaciones de la ciencia y el arte, de las literaturas escritas y las audiovisuales: reorganización de los saberes y del mapa de los oficios desde los flujos y redes por los que hoy se moviliza no sólo la información sino el trabajo, el intercambio y la puesta en común de proyectos, de investigaciones científicas y experimentaciones estéticas"71. 



\section{Definiciones}

\section{Ejes sobre la calidad de los encuadres}

Los textos clásicos de la modernidad educativo-comunicacional siempre nos permiten volver a leerlos en clave de pasar de los problemas a las problemáticas... dar cuenta de los procesos por los cuales los datos pueden constituirse en información para la acción... testificar desde el futuro cuáles son los desafíos pendientes.

Porque, en los procesos educativos que nos ocupan en nuestra cotidianeidad comunicacional argentina y latinoamericana, los "nuevos medios" siguen estando subutilizados o, directamente, ausentes; la generación de docentes no ha tenido continuidad y coherencia en sus procesos formativos; la conciencia sobre la realidad de los contextos de recepción de cada contenido pretendidamente necesario no ha alcanzado a incorporarse al circuito de la comunicación formativa; la investigación de las prácticas y saberes en desarrollo dentro de lo que genéricamente se nomina "educación" no termina de dar cuenta del impacto que los cambios en el campo de la información han producido.

Hoy sabemos que lo que ha crecido es el número de personas que son sujetos de derecho a la educación-comunicación; que la formación docente está tironeada entre demandas hipercríticas o -por el contrariode "integración" acrítica, entre curriculas globales y recorridos de sobrevivencia individual, entre especificidades didácticas y un trabajo que les demanda más de menos; que la estructura material donde se apoya y desarrolla la educación es la suma de lo faltante y no la posibilidad para el desarrollo; y que los medios todavía "suceden" principalmente fuera de las aulas pero, definitivamente, dentro de los campos educativos.

En 2014, aquel futuro ha sucedido y, sin embargo, el desafío parece seguir definido por los mismos problemas y las mismas problemáticas: 
Porque, de aquellas posiciones acerca del Progreso definidas como líneas en disputa por la hegemonía cultural han quedado las cicatrices, las marcas identitarias, pero siguen estando pendientes la calidad institucional de la inclusión completa, la justicia social efectiva, la posibilidad de los consensos, la obligación de la sustentabilidad ambiental, la riqueza de la interculturalidad... el futuro que será posible si reconocemos la historicidad y acordamos un sentido colectivo y común... si consensuamos un proyecto que recoja todos los "por qué" lo estamos haciendo y articule los "para qué" lo queremos hacer.

Hemos tomado como ejes de calidad de los encuadres curriculares a cuatro dimensiones principales:

- Dimensión Tecnológica. Donde el curriculum refleja las transformaciones que la revolución científico-tecnológica produce en el campo profesional, provocando nuevas instancias de conocimiento, habilidades y competencias. Y, además, tiene que dar cuenta de la restructuración de las percepciones, la necesaria adecuación de las competencias lingüísticas y de las competencias técnicas, la problematización y la tensión entre interactividad e interacción comunicativa, las nuevas formas de consumo, en tanto uso y apropiación de las innovaciones tecnológicas.

- Dimensión Cultural. El horizonte formativo clave está determinado por las mediaciones en los procesos comunicacionales, por la aparición en el curriculum del problema de la cultura mediática, de las transformaciones en las dinámicas culturales y en la vida cotidiana, donde se juegan -entre otros- procesos de hibridación, lucha de identidades, desterritorialización y reterritorialización.

- Dimensión Social. En el marco de la sociedad mediatizada, el curriculum tiene que dar cuenta de las transformaciones en las formas de socialidad en sociedades altamente fragmentadas y segmentadas, de los nuevos reconocimientos por clase o sector y las articulaciones en diferentes movimientos sociales, de la transformación de los sujetos y de los modos de subjetividad e institucionalidad, de la tensión entre la exclusión, la inclusión y las formas de supervivencia sociocultural. 
- Dimensión Política. El curriculum tiene que reflejar esta transformación de lo político, provocando la problematización y las nuevas formas de intervención y producción que están produciendo la refiguración de las esferas públicas, la permanente rearticulación de redes sociopolíticas y el desenvolvimiento de la videopolítica o la política a través de los medios.

Es decir, tomamos que esta evaluación formula un juicio de valor construido a partir de los datos descriptos durante el proceso que hemos realizado. En palabras de José Félix Angulo y Nieves Blanco, hemos transcurrido valorando acciones y realizaciones. En rigor, si lo hemos realizado complejamente, permitirá comprender el entramado profundo de la cultura que nos prohija, en la interrelación con nuestros entornos más densos.

Omar Rincón ${ }^{72}$ sostiene que la comunicación es un modo de producir sentido social, de afirmar o transformar percepciones y representaciones, de conectar con promesas de futuro y de buscar las formas narrativas del mundo. Así la acción mediática recrea, renueva, recontextualiza los ritos y las creencias humanas para producir un paisaje simbólico. Los medios de comunicación han construido su propias culturas o modos de significar, de vincular y ritualizar el mundo de la vida.

“En la medida en que el espacio de comunicación se torna cada día más estratégico, decisivo para el desarrollo o el bloqueo de nuestras sociedades -como revela la densa relación entre violencia e información, la incidencia de los medios en la legitimación de los regímenes de populismo autoritario, y de nuevas tecnologías en la reorganización de la estructura productiva, de la administración pública e incluso en la estructura de la deuda externa- se hace más nítida la demanda social de un comunicador capaz de enfrentar la envergadura de lo que su trabajo pone en juego y las contradicciones que atraviesan su práctica. Y eso es lo que constituye la tarea básica del intelectual: la de luchar contra el acoso del inmediatismo y el fetiche de la actualidad poniendo contexto histórico, profundidad y una distancia crítica que le permita comprender y hacer comprender a los demás el sentido y el valor de las transforma- 
ciones que estamos viviendo. Frente a la crisis de la conciencia de que en comunicación se juega de manera decisiva la suerte de lo público, la supervivencia de la sociedad civil y de la democracia ${ }^{73 "}$.

Lo que exige transformar la docencia en un espacio de experimentación social posibilitando la apertura del trabajo académico a nuevos modos de relación con la "vida real". Pues lo que se torna irreal, especulativo y estéril al trabajo académico no es la distancia indispensable que requiere la producción de conocimientos sino la irrelevancia social de los problemas que abordan y el formalismo de las soluciones tanto teóricas como prácticas.

Como señalamos antes, otro punto de mi investigación será analizar las transformaciones en la constitución del campo de la comunicación y proponer un paradigma formativo superador en diálogo con los nuevos modos de producción, circulación y apropiación del conocimiento en el escenario de la convergencia tecnológica. Por esto, considero importante explicitar que parto de entender a la dimensión tecnológica como constituyente de lo humano, como testimonio "de la potencia de la creatividad humana". "Es a ese desafío al que van dirigidos los esfuerzos por pensar la técnica como entorno tecnológico y ecosistema comunicativo, hoy socialmente tan estratégico como el ecosistema verde (...) es el entorno técnico el que se nos vuelve aceleradamente natural pues cada vez se hace más parte de nuestra corporeidad, de nuestra movilidad y de nuestra cognitividad".

Las tecnologías son sociales, surgen en un contexto al que modifican y son, a su vez, modificadas por él. “(...) Los inventos técnicos se dan siempre dentro de las sociedades, y que las sociedades son siempre algo más que la suma de relaciones e instituciones de las cuales los inventos técnicos han sido excluidos mediante una definición falsamente especializada. Estos hechos bastante obvios son oscurecidos aún más por la tendencia generalizada a emplear los términos «invento técnico» y «tecnología» como si fuesen equivalentes (...) una tecnología es, en primer lugar, el marco de conocimientos necesarios para el desarrollo de dichas habilidades y aplicaciones $y$, en segundo lugar, un marco de 
conocimientos y condiciones para la utilización y aplicación prácticas de una serie de ingenios (...) Lo que importa en cada nivel es que una tecnología siempre es, en el sentido más amplio del término, social"

Si bien Internet surge atravesada por la lógica capitalista, los usos que los sujetos hacen de ese espacio puede otorgarle otros sentidos, otras significaciones. Pensar esto es posible si se entiende al poder desde la hegemonía y se piensa en la posibilidad de resistencias, de brechas, de negociaciones. La hegemonía es "un complejo entrelazamiento de fuerzas políticas, sociales y culturales (...) constituye todo un cuerpo de prácticas y expectativas en relación con la totalidad de la vida: nuestros sentidos y dosis de energía, las percepciones definidas que tenemos de nosotros mismos y de nuestro mundo (...) es un complejo efectivo de experiencias, relaciones y actividades que tiene límites y presiones específicas y cambiantes" Es siempre un proceso y nunca puede ser entendida como individual.

Entendemos al poder desde la hegemonía, nos permite correrse de pensarlo sólo como dominación, coerción o estructura. Desde este posicionamiento teórico es posible, entonces, pensar estas prácticas. 


\section{La comunicación como campo de estudio}

"Cuantos más años me dedico a estudiar la comunicación, menos comunicólogo me siento y más desconfío de la comunicología y más me doy cuenta de que necesito un trabajo muy creativo, de carácter pluridisciplinar. Al mismo tiempo, hay que tener en cuenta un grado de humildad teórico epistemológica que acudiendo a las ciencias sociales, pero aportando, por ejemplo, a la historia y a la antropología un tema, un sujeto, que jamás ha sido estudiado por ellas. En suma, tenemos aquí una teoría un poco particular, que es la de no querer construir la disciplina, pero atesorando un objeto de máxima importancia. Esta es la complejidad de nuestro objeto de estudio" 74 .

Miquel de Moragas

Si algo hemos aprendido en nuestra América Latina es que lo comunicacional es demasiado complejo como para pretender verlo a través del ojo de una cerradura.

\section{Comunicación: campo propio abierto a interpelaciones}

Entrado ya el siglo veintiuno lo podemos definir como un campo de saberes con relativa autonomía a otros campos, porque ya los estudios de comunicación realizaron su propia trayectoria. "Es posible hablar del campo porque sí existe un debate específico en torno al estatuto de la comunicación, pero no es posible imaginar que este debate se dé al margen de otros saberes por fuera del campo, como muchas veces se afirmó respondiendo a intereses puramente burocráticos".75

De todos modos, continua pendiente la necesidad de complejizar el campo de la comunicación hacia otras disciplinas y saberes. Pensar además en la alternativa que no haya existido nunca y no exista una disciplina de la comunicación sino más bien unos problemas complejos en torno a la pregunta por la comunicación, que demandan la mirada de las

74 MORAGAS, Miquel. "La investigación y formación en comunicaciones" En la era de la globalización. CICOSUL. LIMA 1998. Pag 18 enunciado por MORAGAS en ocasión del IX Encuentro Latinoamericano de Comunicación Social

75 SAINTOUT, Florencia "Abrir la Comunicación. Tradición y movimiento en el campo académico" (editora) Ediciones de Periodismo y Comunicación Social. UNLP 2003 
múltiples disciplinas de las ciencias sociales. "y es también posible pensar que alrededor de esta demanda se ha ido constituyendo un conjunto de saberes que tiene como particularidad el hablar de comunicación desde una perspectiva pluridimensional"

La Comunicación es analizada asiduamente desde nuevos enfoques y susceptible a transformaciones, ambas son consecuencia de la velocidad con que se desarrolla el objeto de su interés, y a la aceleración de los procesos históricos y sociales que caracterizan estos tiempos.

"El desarrollo de los estudios de comunicación se ha visto marcado por hechos que rebasan la dinámica propia de las disciplinas que lo integran: por una parte lo reciente de su constitución como campo académico y la fuerte incidencia de la revolución tecnológica en la conformación y acelerada transformación de sus objetos-de estudio, y por otra la constante interacción entre las variaciones sociales, los cambios culturales y políticos y las modificaciones que en una perspectiva histórica iban teniendo las comunicaciones en el mundo y en cada país. De esa manera se encontraban en un juego no siempre simétrico las comprensiones disciplinares con los acontecimientos sociales, los caminos de la investigación con las nuevas exigencias de los mercados o de la política. Esta interpenetración llenará de tensiones pero también de sugerencias el campo de los estudios de comunicación: mientras en un momento la comunicación pensada como difusión se inserta funcionalmente en procesos de desarrollo, en otro incursiona en una cartografía de los gustos que delinean las nuevas conformaciones de lo social o los trazos de las violencias que durante años han asolado el país"76.

La comunicación, avanza constituye los procesos sociales, es habitada e interpelada desde diferentes instancias de la sociedad. La investigación académica no llega a abarcarla, a comprender las irrupciones, las transformaciones, las nuevas demandas. Si fue implementada, desde las estrategias desarrollistas y los intentos modernizadores de los años sesenta, será atravesada por la apertura de los mercados y el predominio de las lógicas empresariales de los años ochenta y noventa. 
El campo de la comunicación se forma así en América Latina del movimiento cruzado de dos hegemonías: la del paradigma informacional/instrumental procedente de la investigación norteamericana, y la del paradigma crítico / ideológico en las ciencias sociales latinoamericanas. Durante los años sesenta, setenta en América Latina se habían comenzado a trazar las primeras líneas en torno a la institucionalización de los estudios de comunicación impulsados por el Centro Internacional de Periodismo para América Latina (CIESPAL), con un claro alineamiento a las políticas del desarrollo para la región. La modernización desarrollista propaga un modelo de sociedad que convierte a la comunicación en el terreno de punta de la "difusión de innovaciones" y en el motor de la transformación social: comunicación identificada con los medios masivos, sus dispositivos tecnológicos, sus lenguajes y sus saberes propios.

Del lado latinoamericano, la Teoría de la Dependencia será la inspiradora de la articulación del estudio de los medios al de las estructuras económicas y sus condiciones de propiedad, y al análisis del contenido ideológico de los medios que, junto con la teoría crítica y el estructuralismo semiótico, posibilitaron la gestación de una línea de investigaciones de comunicación propiamente latinoamericana. Esta línea de investigación arrastró pronto un serio reduccionismo: el que le niega a la comunicación especificidad alguna en cuanto espacio de procesos y prácticas de producción simbólica y no sólo de reproducción ideológica. “En América Latina la literatura sobre los medios masivos de comunicación está dedicada a demostrar su calidad, innegable, de instrumentos oligárquico-imperialistas de penetración ideológica, pero casi no se ocupa de examinar cómo son recibidos sus mensajes y con cuáles efectos concretos. Es como si fuera condición de ingreso al tópico que el investigador olvidase las consecuencias no queridas de la acción social para instalarse en un hiperfuncionalismo de izquierdas"77.

Es recién en los ochenta cuando podemos hablar de la existencia de un campo de la comunicación porque más allá de las discusiones y problemáticas, no hay previamente ni siquiera un mínimo acuerdo en torno al estatuto de los saberes que abordaban los medios como nuevos 
objetos. El desplazamiento de los medios a las mediaciones, planteo fundamental para la institucionalización del campo se empieza a instalar en 1987. El maestro Jesús Martín Barbero, intelectual referente trabajó durante más de diez años y operará, a través de su obra como nominador, clasificador del campo. “De los medios a las mediaciones, comunicación, cultura y hegemonía" y "Procesos de comunicación y matrices de cultura, Itinerario para salir de la razón dualista" permiten situar el pasado del campo desde unas dualidades fuertes entre apocalípticos (la teoría de crítica de la escuela de Frankfurt) e integrados (el estructural funcionalismo); entre un pensamiento aristocrático ilustrado y otro populista y folklórico de la cultura; entre una mirada que opone lo masivo a lo popular. Y en cómo desde estas dualidades se había pensado en un objeto de la comunicación: los medios masivos como transmisores de información provocaban efectos, ya sea de democratización y difusión de la cultural. Y en cómo desde estas dualidades se había pensado en un objeto de la comunicación: los medios masivos como transmisores de información que provocaban efectos, ya sea de democratización y difusión de cultura como de dominación y alineación.

Por otro lado, Barbero caracterizará la postura dualista del pasado de los estudios de comunicación e América Latina en el enfrentamiento entre una perspectiva que llamará ideologista o crítica, mira a la comunicación como “herramienta de dominación" y la mirada desarrollista, la comunicación es concebida como "herramienta de educación". Esto nos lleva a pensar que la misma forma que los frankfurtianos y los funcionalistas se anulaban en su visión de los medios y la comunicación, los intelectuales e investigadores que optaron por la perspectiva ideologista o del desarrollo también compartieron una mirada sobre los medios definiéndolos como transmisores de información para un receptor indefinido y acrítico, mudo.

El futuro del campo tendrá que ver, entonces, con la salida de las dualidades desde el nuevo territorio teórico del mestizaje, que constituirá nuevos objetos permitiendo el pasaje de la mirada anclada en los miedos hacia las mediaciones culturales. Planteada la inadecuación del modelo mediconéntrico e instrumental para entender la comunicación, "Barbero encabeza una ruptura fundamental en el campo: el despla- 
zamiento de una teoría centrada en los medios hacia las mediaciones culturales; de las determinaciones tecnológicas a la cultura. La comunicación ahora será pensada desde la cultura, como constitutiva de la cultura, y está definida desde una mirada sociosemiótica, lo que implica la atención del plano simbólico pero también las dimensiones materiales e históricas"78.

Desde la perspectiva y el concepto de campo de Pierre Bourdieu se fundamenta teóricamente esta construcción conceptual de los estudios de comunicación, sus agentes e instituciones. Se trata de concebirlo como "'espacio' sociocultural de posiciones objetivas donde los agentes luchan por la apropiación del capital común"79 El campo académico de la comunicación, homologable al campo científico de Bourdieu, se presenta para Fuentes Navarro constituido por tres subcampos: "el de la producción de conocimiento o "subcampo de la investigación académica", el de la reproducción del conocimiento o "subcampo de la formación universitaria", y el de la aplicación del conocimiento o "subcampo de la profesión" ${ }^{\prime 80}$. Este trabajo tiene su principal interés y desarrollo en el primero de estos subcampos, para el que define nueve procesos de estructuración en las escalas individual, institucional y sociocultural

Los procesos de estructuración del campo académico en América Latina, permiten vislumbrar el reto que aún enfrentamos para consolidar un trabajo sistemático que nos permita reconocer los diversos factores implicados en el proceso de institucionalización del campo académico de la comunicación. El campo académico de la comunicación en América Latina podrá avanzar en su legitimación y generar explicaciones que orienten las transformaciones sociales "mediante la formación universitaria de agentes académicos y profesionales competentes para producir socialmente sentido sobre la producción social de sentido"81.

78 SAINTOUT, Florencia "Abrir la Comunicación" Op Cit.

79 FUENTES NAVARRO, Raúl. “El campo académico de la comunicación en México como objeto de análisis auto-reflexivo”, en Lozano, J.C. (ed.) La comunicación en México: (2005)

80 FUENTES NAVARRO “El campo académico de la comunicación en México como objeto de análisis auto-reflexivo” Op Cit.

81 FUENTES NAVARRO. Op Cit 
Somos testigos del proceso de maduración del propio campo, madurez que se manifiesta en la creciente referencia a la propia historia en la conciencia autocrítica del trabajo que realizamos y en la claridad respecto de los retos que hemos de enfrentar en el futuro.

\section{La comunicación: valor estratégico}

La comunicación hoy es muchas cosas a la vez; es un conjunto de tecnologías que permite multiplicar, a través del tiempo y del espacio, las palabras, los sonidos y las imágenes; pero también es parte de un sistema de relaciones sociales, culturales y cada vez más, económicas. Guillermo Orozco Gómez definió bien la complejidad constitutiva del campo de la comunicación:

"Pero la dificultad también estriba en el hecho de que la comunicación, a diferencia de otras disciplinas u objetos de estudio, es a la vez que: paradigma, campo interdisciplinario,-fenómeno, práctica o conjunto de prácticas, proceso y resultado, parte esencial de la cultura y la innovación cultural, soporte simbólico y material del intercambio social en su conjunto, ámbito donde se genera, se gana o se pierde el poder, enlace y registro de agentes, agencias, movimientos sociales, herramientas de interlocución, espacio de conflicto, conjunto de imágenes sonidos y sentidos, lenguaje y lógica de articulación de discursos, dispositivos de representación, herramientas de control al servicio de unos cuantos y de exclusión de las mayorías en los beneficios del desarrollo, ámbito diferenciador de prácticas sociales. Todo esto y más es la comunicación"82.

En tal sentido, conviene aclarar cuál es el punto de vista que tomaremos: un punto de vista contextual, histórico, cultural. En principio, asumimos la comunicación como tecnologías, luego en s carácter de instituciones sociales. "En vez de insistir en una especialización reductora, se propone una complejidad que enriquezca (...) Se pretende: hacer estallar los frágiles contornos de las disciplinas para que las jerarquías se disuelvan. La comunicación no es todo pero debe ser hablada de todas partes; debe dejar de ser un objeto construido, para ser un objetivo

82 OROZCO GÓMEZ, Guillermo. La investigación de la comunicación dentro y fuera de América Latina. Ediciones de Periodismo y Comunicación. UNLP, 1997 
a lograr. Desde la cultura, desde ese mundo de símbolos que los seres humanos elaboran con sus actos materiales y espirituales, la comunicación tendrá sentido transferible a la vida cotidiana." ${ }^{83}$ Nos comunicamos a través de los significados/sentidos compartidos (o fragmentariamente compartidos) a través de diferentes tipos de códigos. Éstos como sistemas de signos gobernados por reglas, sean analógicos o digitales pueden tener mayor o menor grado de formalización o gramaticalización en incluye no sólo a la lengua, oral o escrita, sino diversos intercambios no verbales: lo corporal, lo gestual, mirada, movimiento y la distancia, hasta los propios sentidos. (hay culturas visuales, auditivas, olfativas, táctiles) como explica Classen ${ }^{84}$

Si en el paso de la oralidad a la escritura se perdieron destrezas mnemotécnicas y se adquirieron nuevas capacidades de abstracción y de mediación, si con la fotografía el cine o la televisión se aprendió a ver cuerpos cortados por la mitad o leer metonímicamente o a recuperar el valor significativo de la imagen o de la audición, con las nuevas tecnologías, con la articulación digital, la interconectividad (con la pantalla por ejemplo), las posibilidades de almacenamiento y de procesamiento de información se están produciendo, a pesar de las enormes brechas infocomunicacionales en el mundo, transformaciones muy fuertes o aceleradas en la "caja de herramientas" de un cerebro cuya potencialidad sólo aprovechamos de manera muy limitada.

Lo cierto es que las diferentes formas de comunicación no se dan de manera aislada, cerrada o clausurada, sino simultáneamente. De ahí la importancia de la metacomunicación (comunicar sobre lo que se comunica) o de la posibilidad de contradicciones entre los diversos mensajes que transmitimos. Aquello que Bateson llamó doble vínculo (double bind) por ejemplo: "Un aviso que dice "no lea este aviso". ${ }^{85}$

83 SCHMUCLER, Héctor (1984), “Un Proyecto De Comunicación/Cultura” en Revista Comunicación y Cultura, Vol. 12, Ed. Galerna, México.

84 CLASSEN, Constance "Fundamentos de una antropologia de los sentidos" https://es.scribd.com/doc/115749789/Antropologia-de-Los-Sentidos-Classen

85 BATESON, G., JACKSON, D., HALEY, J. \& WEAKLAND, J., (1956), Toward a theory of schizophrenia. 


\section{Breve paneo por las principales teorías}

Si bien la comunicación y/o la información han sido reducidas a formulaciones matemáticas. Shannon y Weaver conciben la comunicación como un proceso lineal. "El problema de la comunicación, consiste en reproducir en un punto, sea exacta o aproximadamente, un mensaje seleccionado en otro punto. Frecuentemente el mensaje tiene significado; éste se refiere o está relacionado con algún sistema, con ciertas entidades físicas o conceptuales", aportando más tarde la Teoría Matemática de la Comunicación, cuya presentación hicieron con el siguiente enunciado: "La palabra comunicación se usará aquí en un sentido muy amplio para incluir todos los procedimientos por los cuales una mente puede afectar a otra" 86 o sistémicas o homeostáticas como con la cibernética y la teoría general de los sistemas estas operaciones no han podido reducir la estrecha y casi inseparable relación con la cultura (entendida esta desde el punto de vista antropológico y semiótico) y con el contexto, es decir con series diacrónicas y sincrónicas, históricas y sociales.

Esta preocupación por la comunicación o por el sentido - que en definitiva son una misma cosa- no deja de estar relacionada con sociedades que se tornaban cada vez más opacas y donde los sistemas de mediaciones se diversifican cada vez más, provinieran del aumento del intercambio cultural, de la complejidad de las ciudades de la modernidad, del desarrollo de los primeros medios de comunicación masivos o de los primeros avances tecnoelectrónicos en la reproducción de voces, sonidos o imágenes. Precisamente, Héctor Schmucler afirma que en los años 60 la atención de las ciencias sociales, y por ende de la Comunicación, estaba puesta en los Mensajes. Fue así que la semiología pasó a ser un 'instrumento revolucionario' ya que "permitía mostrar la ideología que el texto encerraba" y Althusser -con su definición de 'aparatos ideológicos del estado'- se volvió una "llave maestra para explicar la dominación" es decir, para descubrir las artimañas con las cuales la ideología dominante integraba los procesos de comunicación, penetrando los mensajes con el fin de producir determinados efectos.

86. SHANNON, C. y WEAVER, W. (1949) The Mathematical Theory of Communication. Urbana: University of Illinois Press. Acá hay dos fechas, no sé cuál corresponde. 
En los años setenta, los acontecimientos históricos condicionaron el surgimiento de una nueva teoría de la comunicación latinoamericana; surgió el debate sobre el Nuevo Orden Informativo Internacional, como dice Schmucler, "lo que domina es la lucha por quién tiene la técnica". Esta década se ve signada por dos etapas claramente diferenciables: la ideologista y la cientificista. En la primera de ellas (correspondiente a la primera mitad de la década), "el objetivo estuvo centrado en descubrir y denunciar, articulando la epistemología conductista y la semiótica con una posición de crítica política, los múltiples caminos a través de los cuales la ideología dominante penetra el mensaje y produce determinados efectos: la invasión cultural" ${ }^{87}$

Esta etapa ideologista continua el razonamiento que caracterizaba, según Schmucler, a la década del ‘60 alimentada de un fervor revolucionario fundamentalmente, por el éxito cubano.

La etapa cientificista queda representada simbólicamente, cuando la enciclopedia francesa "Le Grand Robert"88 de 1970 incorpora en su vocabulario la siguiente acepción de comunicación: "toda relación dinámica que interviene en un funcionamiento. Teoría de las comunicaciones y de la regulación Cibernética Información y comunicación", por primera vez, el término 'comunicación' se incorpora al vocabulario científico. Desde entonces, hay una gran persistencia en legitimar la comunicación como una Ciencia. "Asimilando comunicación a transmisión de información mensurable, calculable, objetivable, la teoría matemática y la cibernética proporcionan los conceptos y las operaciones metodológicas necesarias para un momento donde, desde un revival positivista, se reclama 'seriedad' científica para el análisis de la complejidad y dispersión de la comunicación en la cultura. Dejar de hacer política, hacer ciencia, fue la consigna".

Desde ambas perspectivas se valora importancia de la comunicación como Ciencia ya que, "la ciencia consolidaba la autenticidad de los

87 SAINTOUT, Florencia “Descubrir una Comunicación. En búsqueda de las huellas" pag. 27 en “Espacios de Comunicación” ESTEINOU MADRID, Javier Compilador. Universidad Iberoamericana. México 1998

88 Diccionarios Le Robert es el nombre de una casa editorial francesa creada en 1951 por Paul Robert y especializada en la publicación de diccionarios de lengua francesa. 
conocimientos, volvía indiscutibles las opiniones de quienes ejercían la profesión (porque ya no eran simples opiniones) e imponía una exigencia soberana: la investigación". Falta la referencia de la cita De esta manera, para 'adueñarse' de la ciencia había que generalizar el método de investigación y por eso los programas de enseñanza incorporaron "los métodos para la investigación científica". Por otra parte, para los 'críticos', la ciencia debía "arrancar las verdades que el mundo se resistía a mostrar". Como dice Schmucler, "para la ciencia funcionalista el dato cualitativo era la realidad en sí, desde el otro bando se denunciaba la falacia: la realidad está disimulada por esa apariencia de realidad. La ciencia, la verdadera, era la que podía atravesar la opacidad del sentido común para descubrir las leyes estructurales que rigen los procesos naturales, sociales e históricos" ${ }^{\prime \prime 9}$.

En su sentido más amplio, o en una conceptualización mundial, la noción de 'Crisis de los paradigmas' de la reformulación de los principales conceptos que conformaron la visión moderna del mundo. Así'cultura, 'estado,' 'ciencia, 'historia,' 'individuo,', poder"'sociedad,' 'religión', 'masa', 'popular' se redefinen y se dirigen a una complejidad que elimina concepciones lineales, predicciones infalibles, encasillamientos y certezas absolutas. Se trata de una crisis en la que está negada la posibilidad de explicaciones sistemáticas y universales del acontecer social. Los saberes constituyen ahora una serie de narrativas muchas veces dispersas, que existen como aproximaciones parciales construidas desde puntos divergentes. Con la reformulación de esos grandes conceptos llega también la reformulación de las grandes disciplinas de las ciencias sociales, de modo que ya no es tan fácil precisar con claridad sus objetos de estudio, sus especialidades y metodologías.

Ya no se sabe con certeza de qué objeto debería hablar la antropología, qué estudia la sociología, de qué es 'dueña' la comunicación: se producen usurpaciones en territorios que por años habían trabajado, a veces hasta la obsesión, en el marcado de sus fronteras. Se resquebraja así la idea de una teoría ineludiblemente vinculada con la delimitación de un objeto Si puede haber una mayor precisión en lo que debe estu- 
diar las ciencias sociales en general (y no las especialidades), es el fenómeno humano y el objeto el ser cultural.

En lo que a comunicación se refiere, luego de décadas de importar modelos, interpretar los fenómenos sociales con miradas de otras realidades y ante la presencia de numerosos movimientos sociales (lo que Martín Barbero llama 'tercos hechos') en América Latina, en los '80 surge la necesidad -intuida desde hacía tiempo- de consolidar un modelo propio que diera cuenta de las problemáticas y las realidades latinoamericanas. Es así que se reformulan los conceptos esenciales de la vida social y de sus estudios y la comunicación comienza a repensar su campo, sus pertinencias y por ende, comienza a reformular su criterio acerca de la Cultura y el Poder. Nace así, la búsqueda de un modelo práctico que no se acabe en la crítica teórica sino que se desarrolle materialmente en la Sociedad y la Cultura. La crisis en el paradigma de la Comunicación ubicada en la década del '80, significó una ruptura en la visión técnica y cientificista (en la que los 'medios de comunicación' eran el eje) y una consideración más 'subjetiva' en la que el hombre, todo lo que lo rodea (los hombres y sus prácticas) y el intercambio y producción simbólica son la clave para entenderla. "Comienzan a tratarse los problemas de comunicación como problemas culturales o a la inversa, los problemas culturales como problemas de comunicación" ${ }^{\prime \prime 0}$.

María Cristina Mata menciona a Armand Mattelart, a Jesús Martín Barbero y a Héctor Schmucler como los autores paradigmáticos de este nuevo modelo de comunicación. Armand Mattelart, por su parte, sostuvo que era necesario asumir una actitud genealógica de la comunicación. Esto quiere decir, estudiar los orígenes de la comunicación pero no en un sentido cronológico y lineal, sino 'interpretando las interpretaciones' es decir, terminando con las verdades dadas. Propone entonces, una teoría crítica de la comunicación la cual, antes que nada, debe ser una teoría social es decir, una teoría del Estado, una teoría política, una teoría de la hegemonía y una teoría de la democracia. Quien le pone nombre a toda esta corriente es, podría decirse, Héctor Schmucler. Con su Comunicación / Cultura el autor desplaza la idea de Comunicación y Cultura enten- 
diendo que la barra "genera una fusión tensa entre elementos distintos de un mismo campo semántico (...) acepta la distinción, pero anuncia la imposibilidad de un tratamiento por separado"91.

Así la comunicación deja de ser vista como cuestión de técnica, de medios como instrumentos, para transformase en dimensión constitutiva de las prácticas sociales, y los medios como configuraciones culturales históricas. También la noción de cultura se entiende desde un desplazamiento o desbloqueo: no como mera reproducción, reflejo de las condiciones materiales de existencia sino también como producción y recreación social del sentido.

Hagamos, entonces, un repaso por lo que este cambio de paradigma significa:

- Mirada teórica que nos permite comprender a los medios y las tecnologías en tanto:

Actores sociales históricamente situados. Su carácter significativo en la producción, circulación y consumo de las formas simbólicas. Es necesaria contextualización social de su emergencia.

- Las transformaciones que se producen en el orden del poder simbólico (en relación con el económico, el político y el poder coercitivo)La comunicación mediatizada implica siempre un fenómeno social y más aún, un fenómeno de contextualización social.

- Un sistema de significaciones que, dentro de la red cultural, se concreta en el discurso y en la lucha por el sentido. La cultura circula, se produce y se consume en la sociedad.

- Proceso social de producción de formas simbólicas, considerando tales procesos como fase constitutiva del ser práctico del hombre y del conocimiento práctico que supone este modo de ser. 


\section{Comunicación, Medios, Modernidades}

Continuamos profundizando la idea cuya matriz es concebir la comunicación como un proceso social de producción de formas simbólicas. Desde esta perspectiva describimos y estudiamos los medios dentro el proceso de mediatización de una sociedad, para entender cómo participan de los modos de acción e interacción de los hombres entre sí y de estos con el mundo. No se trata de abordar los medios como instrumentos o canales omnipotentes a partir de los cuales se instituye un cierto sentido social. Nos interesa analizar la trama cultural, política y económica en la que se produjo el surgimiento de medios de comunicación, desde las primeras industrias mediáticas en las sociedades europeas pre modernas, hasta la renovación y transfiguración de los modos de percibir el tiempo y el espacio anclados en la revolución que generan en la actualidad la digitalización y las nuevas tecnologías de comunicación. El autor inglés John Thompson, afirma que «el desarrollo de las sociedades modernas se ha caracterizado por transformaciones sistemáticas de lo que, en sentido amplio, podría llamarse el dominio cultural. A finales de la Edad Media y principios del período moderno tuvo lugar una transformación cultural sistemática, en virtud de una serie de innovaciones técnicas asociadas con la impresión, y posteriormente con la codificación electrónica de la información.

A partir de la segunda mitad del siglo XV tuvo lugar un profundo proceso de mediatización de la cultura que produjo, reprodujo y puso en circulación nuevas formas simbólicas a una escala sin precedentes modificando las pautas de comunicación e culturales generadas en este cambio de época. "En todas las sociedades, los seres humanos se dedican a la producción e intercambio de información y contenido simbólico. Desde las más tempranas formas de gestualidad y uso de lenguaje hasta los desarrollos más recientes de la tecnología informática, la producción, almacenamiento y circulación de información y contenido simbólico ha constituido una característica central de la vida social"92.

92 THOMPSON, John (1998) Los media y la modernidad. Una teoría de los medios de comunicación; Barcelona; Paidós Comunicación 
Un cambio muy importante fue en el siglo XV, con la invención de la imprenta. Ocurrió en Alemania en 1456, Johann Gutemberg, un orfebre, diseñó la imprenta de tipos móviles y logró realizar impresiones con un procedimiento tipográfico que ha permanecido hasta los inicios del siglo XX. Para ello sustituyó la madera por el metal, fabricando moldes de fundición capaces de reproducir tipos metálicos suficientemente regulares como para permitir la composición de textos.

Fue esta invención, la impresión tipográfica con tipos móviles metálicos, la que originó el libro moderno. Lo primero que imprimió fue la Biblia, portadora de la palabra de Dios, hasta ese momento estaba en manos de los copistas religiosos, expertos en hacer copias manuscritas. De este modo, serían muy pocos los que accederían a la lectura de la Bilblia. Efectivamente, la mayoría de la gente iba a la iglesia a escuchar la palabra de Dios de boca de los religiosos autorizados. El gran cambio fue que la imprenta posibilitó realizar varias copias a la vez, traducirla a distintos idiomas y permitir una libre interpretación de la Biblia. Esta posibilidad, junto a otros cambios económicos, políticos y sociales, marcaron iniciaron la Modernidad.

Modernidades: "El significado principal de la Modernidad como época. Desde una perspectiva histórica, el advenimiento de la modernidad remite a un largo proceso y a la diversidad de fenómenos y acontecimientos, que desde el siglo XVI erosionaron en Europa, el orden cristianomedieval: La ampliación del mundo conocido a través de los viajes de descubrimiento. Exploración y conquista de territorios extra europeos. La formación de un mercado mundial y el incremento de la producción orientada al intercambio mercantil, que transcurría en territorios cada vez más vastos.

La innovación incesante de los medios de comunicación y transporte. Aparición de nuevas ciencias de la naturaleza, el llamado: "Giro Copernicano" del saber. Giro Antropocéntrico que dominará el discurso filosófico. La formación de los primeros Estados Nacionales Europeos, de tipo burocrático-absolutistas. La proliferación de formas capitalistas de producción que se consolidarán con el surgimiento de la Revolución Industrial en Inglaterra. 
Europa se tornó Moderna en el curso de los s. XVII y XIX. Fue en ese período, con el triunfo del capitalismo como forma de producción dominante y el reemplazo del absolutismo por repúblicas liberales o monarquías constitucionales, cuando se produjo la ruptura neta con el tipo de sociedad que las ciencias sociales Ilamarán más adelante "tradicional". Si bien la modernidad tuvo sus matrices autóctonas en la sociedad y la cultura europeas, la lógica expansiva de esas matrices afectaría a las sociedades y las culturas del todo el planeta, a través de formas coercitivas o inducidas (es decir a través de las comunidades extraeuropeas). La universalización de los principios constitutivos de la modernidad no tuvo en todas partes los mismos resultados y frutos.

El movimiento de la modernidad involucrará poblaciones y territorios remotos y dispares entre sí, -en algunos casos simplemente por los recursos económicos que proporcionan- y sus consecuencias atravesarán las fronteras étnicas y geográficas, de clase y de nacionalidad de religión y de ideología. Si a comienzos del S. XX la modernidad triunfante le confería su unidad al mundo, esa unidad contenía la división entre un grupo de naciones centrales y dominantes por un lado y un vasto conjunto de sociedades que funcionaban como periferia del núcleo central por otro.

"A mediados del mismo siglo, después de las dos guerras mundiales, del alejamiento de la Rusia soviética del área de modernización occidental, del surgimiento de nuevos estados nacionales, los impulsos y las matrices de la modernidad seguían proviniendo del mismo grupo de países. Hay tres elementos que habrán de funcionar como principios organizativos particularmente dinámicos, por lo menos en ciertos países: el capitalismo, la industrialización y la democracia liberal como régimen político sobre la base del Estado Nación" ${ }^{\prime \prime 3}$

El espectáculo moderno era ya en esencia: el reinado autocrático de la economía mercantil, con toda seguridad, el espectáculo es hoy más poderoso de lo que era antes, ¿qué hace con ese poder suplementario? ¿Hasta dónde ha llegado que no hubiera llegado antes? La vaga impre- 
sión de que se trata de una especie de invasión rápida que obliga a la gente a llevar una vida completamente distinta, está ampliamente extendida; con todo y con eso, el hecho se vive más bien a la manera en que se experimenta una modificación inexplicable del clima o de cualquier otro equilibrio natural, modificación ante la cual la ignorancia sólo sabe que no tiene nada que decir. Además, muchos admiten que se trata de una invasión civilizadora, al parecer inevitable, e incluso desean colaborar con ella... “El momento histórico en el cual la mercancía completa su colonización de la vida social" ${ }^{94}$.

El espectáculo es la imagen invertida de la sociedad en la cual las relaciones entre mercancías han suplantado relaciones entre la gente, en quienes la identificación pasiva con el espectáculo suplanta actividad genuina "Todo lo que una vez fue vivido directamente se ha convertido en una mera representación". ${ }^{\prime 5}$ Debord argumenta que la historia de la vida social se puede entender como"la declinación de ser en tener, y de tener en simplemente parecer". Esta afirmación nos invita a visualizar la potencia del capitalismo, sus incidencias y dentro de esta lógica el desarrollo de los medios de comunicación. Esta condición en la cual la vida social auténtica se ha sustituido por su imagen representada, según Debord, que "El espectáculo no es una colección de imágenes, en cambio, es una relación social entre la gente que es mediada por imágenes". ${ }^{96}$

¿Quién produce estas imágenes, de qué modo circulan?; ¿quiénes las distribuyen y quiénes las consumen? Comprender que este proceso de espectacularización, de mediatización de la cultura es constitutivo de las sociedades modernas. A partir de la invención de la imprenta, la cultura, los bienes simbólicos circulan en diversos soportes tecnológicos. En este proceso se tensiona la disputa por el poder, por imponer sentido.

94 DEBORD, Guy “La sociedad del espectáculo (La société du spectacle) publicado en 1967

95 DEBORD, Guy “La sociedad del espectáculo” (La société du spectacle) 1967

96 DEBORD, Guy “La sociedad del espectáculo” (La société du spectacle) 1967 


\section{Comunicación/Poder}

La comunicación como un fenómeno social, pueden ser visto como distinto tipo de acciones con propósito llevadas a término en contextos sociales estructurados. "La vida social está compuesta por individuos que llevan a cabo propósitos y objetivos de varios tipos. En este cometido siempre actúan dentro de un conjunto de circunstancias previamente establecidas, y que ofrecen a los individuos diferentes inclinaciones y oportunidades. Estas circunstancias pueden concebirse como "campos de interacción", para utilizar un término fructíferamente desarrollado por Pierre Bourdieu ${ }^{97}$ Los individuos ocupan posiciones diferentes en el interior de estos campos, dependiendo de los diferentes tipos y cantidad de recursos disponibles para ellos. En algunos casos estas posiciones adquieren una cierta estabilidad a través de la institucionalización, esto es, convirtiéndose en parte de un paquete de reglas, recursos y relaciones sociales relativamente estables. Las instituciones pueden observarse como un determinado conjunto de reglas, recursos y relaciones con cierto grado de persistencia en el tiempo y cierta extensión en el espacio, unidas por el propósito de alcanzar ciertos objetivos comunes. Las instituciones dan forma definitiva a campos de interacción preexistentes y, al mismo tiempo, crean nuevas posiciones en el interior de estos campos, así como nuevas trayectorias para organizar la vida de los individuos que las ocupan.

La posición que ocupa un individuo dentro de un campo o institución está íntimamente relacionada con el poder que él o ella poseen. De manera genérica, el poder es la capacidad para actuar de acuerdo a la consecución de los propósitos e intereses de cada uno, la capacidad de intervenir en el curso de los acontecimientos y de afectar a sus resultados. Al ejercer el poder, los individuos emplean los recursos que tienen a su alrededor; los recursos son los medios que les permiten alcanzar sus objetivos e intereses de manera efectiva. De ahí que, mediante la acumulación de recursos de varios tipos, los individuos puedan aumentar su poder, en el sentido de que, por ejemplo, un individuo podría acumular cierta cantidad de ahorros con el fin de adquirir 
una propiedad. Ya que los recursos pueden acumularse personalmente, con frecuencia también se acumulan dentro de la estructura institucional, que constituyen una importante plataforma para el ejercicio del poder. Los individuos que ocupan posiciones dominantes en grandes instituciones pueden contar con inmensos recursos a su disposición, lo que les permite tomar decisiones y perseguir objetivos que tienen implicaciones de largo alcance. Comprendido en este sentido general, el poder es un fenómeno social penetrante característico de los diferentes tipos de acción y encuentros, desde las acciones políticas visibles de los representantes del Estado hasta el mundano encuentro de individuos en la calle. El poder entendido desde la hegemonía, que implica coerción, pero también consensos, y que se visualiza en nuestras cotidianidades, en nuestras luchas diarias por las representaciones y los sentidos en una modernidad latinoamericana.

\section{De la Ciencia en la Comunicación}

"El estatuto disciplinario de los estudios sobre la comunicación es, quizá, el tema crucial de debate sobre el pasado, el presente y sobre todo, el futuro de nuestro campo académico. En él confluyen los múltiples y complejos factores históricos que determinan su institucionalización, tanto en el plano cognoscitivo (saberes teórico-metodológicos) como en el social (haceres institucionalizados). En la última década, algunos investigadores de la comunica-ción hemos orientado nuestros mejores esfuerzos para analizar y formular sistemática, crítica y autoreflexivamente los procesos de constitución de ese campo; en mi caso, específicamente en la escala del contexto mexicano.

Raúl Fuentes Navarro 98

La ciencia, tal como la conocemos actualmente, surge en el mundo moderno. Lo anterior no implica que a partir de la Modernidad exista el conocimiento, sino esta forma particular de concebirlo y legitimarlo. Lo que se visibiliza o cobra forma con la Modernidad, es esta manera particular de organizar y presentar el saber. A la nueva forma de organización que constituyó la Modernidad le correspondió un nuevo método para fi-

98 FUENTES NAVARRO, Raúl “La investigación de la comunicación en América Latina” Diálogos de la Comunicación. № 56, octubre de 1999. . 
jar creencias asociado a la ciencia, caracterizada por la "eficacia", denominada "ciencia restringida"; a partir de aquí los criterios de validación de la verdad dejaron de regularse por principios metafísicos y/o de autoridad y comenzaron a legitimarse por medio del método científico. El método científico de la eficacia caído en la inmediatez se asocia al método hipotético deductivo o falsacionismo enunciado por Popper99, en el que no se puede determinar la verdad de una premisa, sino que sometiéndola a comprobación empírica se determina su falsedad o su eficacia; es decir la validez de una premisa -hipótesis, creencia, teoría o regla- está dada por su eficacia y esta se comprueba sólo a partir de someterla a la mirada del falsasador. Este método restringido porque presenta una negación del proceso dialéctico, excluye las formas de validación del conocimiento a otros métodos, históricamente constitutivos de la praxis social. Aún hoy tienen vigencia en esa organización (como el sentido común derivado de la experiencia individual o colectiva, o los principios de autoridad comunitaria, social o religiosa). Es decir, un método que asuma su constitución dialéctica e histórica no puede oponerse a sus antecesores sino que debiera retomarlos y superarlos.

La restricción del método hipotético-deductivo se vuelve más evidente al tratar de implementarlo en las ciencias sociales. Así este método de la ciencia es restringido, al tener una visión sesgada de los procesos propios de la función autorregulativa que constituye el conocimiento, pone en crisis esa función ya que no cumple cabalmente su razón de ser: proporcionar criterios de verdad a través de los cuales la humanidad pueda generar representaciones y dar explicaciones a sus problemas. Dicho de otra manera, falla como método para determinar lo indeterminado. El sociólogo y Filósofo francés Edgar Morín100 observa esta limitación que presenta la forma hegemónica de conocer: “los métodos y estructuras de nuestro conocimiento nos impiden percibir y concebir la complejidad de lo real, es decir, también la complejidad de nuestra época y la complejidad del problema del conocimiento". Morín afirma: "A un paradigma de pensamiento, a un modo de conocer la realidad, le corresponde un paradigma ético, un paradigma estético, un paradigma

99 Popper, K. Filósofo (Austria 1902- Inglaterra 1994). 
de la vida", es decir, que a un paradigma de pensamiento le corresponde un método para establecer creencias.

Este método de conocer de la ciencia restringida se perfeccionó durante la Modernidad y tuvo como rasgo distintivo la hiperespecialización del conocimiento en campos disciplinares reducidos. Así, en sintonía con la organización cultural de la que emerge, la Modernidad, llegó a su momento de maduración plena con la globalización y como en todo proceso dialéctico ese momento de auge coincide con la puesta en evidencia de la crisis. Su particularidad reside en la pretensión de ser un conocimiento sistemático sobre la realidad, si bien esta afirmación es cierta, el saber ligado a la ciencia estaba restringido inicialmente a la búsqueda de leyes naturales universales comprobables empíricamente que se mantenían en todo tiempo y espacio, asociando a la ciencia con la ciencia natural, el método experimental, por ejemplo. Este origen va a marcar fuertemente los desarrollos posteriores del conocimiento hasta nuestros días. Esta asociación inicial a las ciencias naturales legitimó un modo de hacer ciencia basado en el método científico y el procedimiento experimental.

En su obra "Una epistemología del Sur: la reinvención del conocimiento y la emancipación social", Boaventura de Sousa Santos ${ }^{101}$ nos señala: "Tiene muy poco sentido hacer una crítica pretendidamente radical de la modernidad occidental sin cuestionar el mecanismo fundamental de su reproducción: la reducción de la realidad a lo que existe... Tiene igualmente poco sentido hacer una crítica culturalista a la modernidad occidental, por más radical que sea... dejando en la sombra los procesos económicos, sociales y políticos que tanto se reproducen en la crítica la cultura, como en la cultura de la crítica;... y que debiéramos preguntarnos por el valor del conocimiento acumulado en el enriquecimiento o empobrecimiento práctico de nuestras vidas, o sea por la contribución

101 Boaventura de Sousa Santos: doctor en Sociología del derecho por la Universidad de Yale y profesor catedrático de Sociología en la Universidad de Coímbra.1 Es director del Centro de Estudios Sociales y del Centro de Documentación 25 de Abril de esa misma universidad; además, profesor distinguido del Institute for Legal Studies de la Universidad de Wisconsin-Madison.1 Se lo considera uno de los principales intelectuales en el área de ciencias sociales, con reconocimiento internacional, con especial popularidad en Brasil, principalmente, después de su participación en varias ediciones del Foro Social Mundial en Porto Alegre. Es uno de los académicos e investigadores más importantes en el área de la sociología jurídica a nivel mundial. 
positiva de la ciencia a nuestra felicidad". Más adelante, el propio Boaventura, profundiza: "...la ciencia en general y no sólo las ciencias sociales se pautaban por un paradigma epistemológico y un modelo de racionalidad que daban señales de estar exhaustos, señales tan evidentes que podríamos hablar de una crisis paradigmática... ese paradigma... el positivismo... se basa en ideas fundamentales: distinción entre sujeto y objeto y entre naturaleza y sociedad o cultura; reducción de la complejidad del mundo a leyes simples susceptibles de formulación matemática; una concepción de la realidad dominada por el mecanicismo determinista y de la verdad como representación transparente de la realidad; una separación absoluta entre conocimiento científico -considerado el único válido y riguroso-y otras formas de conocimiento como el sentido común o los estudios humanísticos; preferencia por la causalidad funcional, hostil a la investigación de las "causas últimas", consideradas metafísicas, y centrada en la manipulación y transformación de la realidad estudiada por la ciencia"102.

La disputa sobre qué es conocimiento es una lucha por quién controla el conocimiento del mundo. En esta línea, el peso de las ciencias naturales y exactas "oprimió" el desarrollo de las ciencias sociales, subordinándolas a una ciencia menor o prescribiendo su modo de ser, a imagen y semejanza del modelo experimental/positivista. Este proceso moderno también delimitó el modo fragmentario de conocer a partir de la disciplinarización. La separación en ámbitos disciplinares, como concentración en zonas separadas (intelectualmente productivas), presenta consecuencias hasta el día de hoy. Las primeras disciplinas en el campo de las ciencias sociales en obtener legitimidad y un proceso de institucionalización fueron la historia, la economía, la sociología, la ciencia política y la antropología. La puja entre las denominadas ciencias "duras" y ciencias "blandas" posibilitó un camino que se fue abriendo, e implicó también el reconocimiento de nuevos problemas y nuevas formas de resolverlos. Este recorrido no fue posible, por supuesto, sin una nueva configuración sociopolítica del mundo. Recién a mediados del siglo XX 
encontramos un reconocimiento a las ciencias sociales y a sus modos de relacionarse con el saber"103.

A mediados de la década del 60 , como consecuencia de la crisis de la Ciencia positiva y en el marco de las duras críticas al concepto de racionalidad moderna, se plantea desde las ciencias sociales un nuevo modo de entender la sociedad a partir de su carácter simbólico. Así, con el giro lingüístico o giro semiótico se asume que los seres humanos no podemos dejar de conferir sentidos. A partir de ello cambian los modos de concebir y analizar la escritura y la lectura. En términos comunicacionales cambian las claves por medio de las que se estudian los textos y mensajes en las instancias de producción y recepción; deja de pensarse a la primera instancia como productiva y a la segunda como reproductiva, y ambas son entendidas como determinadas y determinantes del orden simbólico social. Esto trae aparejado un giro ontológico que trasforma los procedimientos de las ciencias sociales: la actividad de interpretar pasa a ser entendida como constitutiva de todo sujeto y a la vez constituyente del mundo social. De ahí el denominado giro hermenéutico, en el que los científicos sociales reconocen el carácter performativo de la teoría: la comprensión de un fenómeno -y especialmente su interpretación y la escritura interpretativa- son, por un lado, un acto productivo, de creatividad, y, por otro, reproductivo e histórico (Barthes, 1976; Geertz, 1989; Guiddens, 1987 y Schuster, 2002).

Este marco conflictivo es el contexto del proceso de institucionalización del campo de la Comunicación en América Latina. Así, el debate disciplina / interdisciplina / transdisciplina es desde el principio un eje en disputa, constitutivo y constituyente de la identidad del campo. Todo esto, sumado a la amplia gama de aportes epistemológicos, teóricos y metodológicos de los culturalismos y las teorías críticas (siempre periféricos de las Ciencias Sociales, desde los cultural studies hasta los Estudios de Recepción, desde los estudios Poscoloniales hasta la investigación / acción) son motivos de las dificultades que encuentra el campo de la Comunicación Social para pensarse a sí mismo, y a la vez son huellas ineludibles de un autoconocimiento necesario. 
“Los estudios de comunicación y cultura fueron ampliando su campo, también por necesidad, a todas las situaciones comunicacionales humanas desde la conversación o la comunicación gestual hasta el espacio semiótico global y globalizado de la cultura. Así el campo se valió de préstamos, asociaciones y apropiaciones de otras disciplinas. A la vez, la fuerte impronta histórica de la práctica en el campo de la Comunicación, tanto desde las dinámicas productivas de periodistas y comunicadores sociales como desde la investigación para la resolución de problemas concretos de la comunicación y la cultura, en la interacción con otros campos científicos, ha servido muchas veces para deslegitimar a la Comunicación por su falta de tradición epistemológica disciplinar"104

A pesar de que las potencias financian la investigación en ciencias sociales en tanto paradigmas científicos acordes a sus objetivos, se logra debatir el eurocentrismo y la especificidad de objetos. Es así que las ciencias sociales logran instalar la importancia de trabajar desde una mirada micro, particular, sin pretensión de generalización. Lo anterior se sustenta en que el estudio de un caso tiene relevancia para futuros casos y los casos son interminables. Esta premisa se basa en la capacidad interpretativa de los procesos sociales y no en la búsqueda de la explicación monocausal de los mismos. Esta diferencia es sustancial: mientras el modelo hegemónico del conocimiento avalaba la pretensión de generalización como impacto social del saber, se comienza a argumentar la importancia de analizar e interpretar casos. Los mismos aportan al conocimiento sobre ellos mismos, pero también aportan a una discusión relacional con otros casos posibles.

Las ciencias sociales logran paulatinamente un posicionamiento diferente en el plano académico y científico. La complejidad creciente de la perspectiva de las ciencias sociales lleva a cuestionar la mirada disciplinar, proponiendo enfoques interdisciplinarios y transdisciplinarios. La comunicación, como campo de saber, transita esta problemática en su constitución misma. La particularidad de las ciencias sociales reside en que aquello indagado es también un sujeto, por lo que la rela-

104 GIORDANO, Carlos Editor "Cuestiones sobre Epistemología, Teoría y Metodología del Campo de la Comunicación" Questions- Ediciones de Periodismo y Comunicación 1a ed. - La Plata: Universidad Nacional de La Plata. Facultad de Periodismo y Comunicación Social, 2011. 
ción entre el "objeto de estudio" y el investigador es específica. Estamos frente al hombre que estudia al hombre y sus prácticas. A esta complejidad se suma la multiplicidad coexistente de perspectivas teóricas no evolutivas que instalan la posibilidad de la interpretación diferencial según el posicionamiento teórico y epistemológico que se adopte Entonces, no hay una única forma de conocer, sino que las diversas modos son constructos sociohistóricos y epistemológicos legitimados en un momento dado. El saber se constituye en un relato que mantiene características similares a cualquier otro relato: su carácter discursivo y su construcción subjetiva. Se trata de comprender las luchas, disputas y debates en el campo del conocimiento, no son debates por la verdad o la realidad, sino sobre el modo de construir discusivamente los relatos de la realidad. "Transdisciplinariedad en los estudios de comunicación no significa... la disolución de sus objetos en los de las disciplinas sociales sino la construcción de las articulaciones -mediaciones e intertextualidades- que hacen su especificidad. Esa que hoy ni la teoría de la información ni la semiótica, aun siendo disciplinas "fundantes", pueden pretender ya. Como lo demuestran las puntas de investigación de estos últimos años en Europa y los Estados Unidos..., y que como en América Latina, presentan una convergencia cada día mayor con los avances de los estudios culturales, que hacen posible la superación de la razón dualista que impedía pensar las relaciones y conflictos entre industrias culturales y culturas populares por fuera de los idealismos hipostasiadores de la diferencia como exterioridad o resistencia en sí. (...)

La expansión e interpenetración de los estudios culturales y de la comunicación no es fortuita ni ocasional. Ello responde al lugar estratégico que la comunicación ocupa tanto en los procesos de reconversión cultural que requiere la nueva etapa de modernización de nuestros países, como en la crisis que la modernidad sufre en los países centrales. No es posible comprender el escenario actual de los estudios de comunicación, y aún menos trabajar en su prospectiva, sin pensar esa encrucijada"105. Probablemente el aporte fundamental de los estudios 
culturales en su vertiente británica, estadounidense o latinoamericana, para los estudios de comunicación sea apuntar hacia un marco de interpretación (precisamente sociocultural) que "por una parte, reintegre conceptual y metodológicamente la diversidad política, cultural y existencial de los agentes de la comunicación, y por otra permita imaginar las dimensiones de la acción comunicativa en términos constitutivos y no solo instrumentales"106.

Williams define a la cultura en el centro mismo de un área principal del pensamiento y la práctica modernos aparece un concepto que es utilizado en las descripciones, "cultura" qué en sí mismo comprende no sólo los objetos, sino también las contradicciones a través de las cuales se ha desarrollado. El concepto funde y confunde a la vez las tendencias y experiencias radicalmente diferentes presentes en formación. Por tanto resulta imposible llevar a cabo un análisis cultural serio sin tratar de tomar conciencia del propio concepto; una conciencia que debe ser histórica. La cultura como un "proceso social total", y plantea que la hegemonía va más allá que el concepto de cultura porque relaciona a este proceso con las distribuciones específicas del poder. Entender la dominación y la subordinación en las sociedades actuales. Si bien es cierto que los que detentan la dominación material son también los que ejercen la dominación espiritual, lo que resulta decisivo no es solamente el sistema consciente de creencias, significados y valores impuestos, es decir la ideología dominante, sino todo el proceso social vivido, organizado prácticamente por estos valores y creencias específicos.

La ideología constituye un sistema de significados, valores y creencias relativamente formal y articulado, que conforma una concepción universal o una perspectiva de clase. En el proceso de "imposición" de esta ideología, la conciencia relativamente heterogénea, confusa, incompleta o inarticulada de los hombres es atropellada en nombre de este sistema decisivo y generalizado. Plantea Williams que "en una pers-

NAVARRO (1991): “Un campo cargado de futuro. El estudio de la comunicación en América” Latina. Guadalajara: ITESO/ Maestría en Comunicación, octubre de 1991. 
pectiva más general, esta acepción de "una ideología" se aplica por medios abstractos a la verdadera conciencia tanto de las clases dominantes como de las clases subordinadas. Una clase dominante tiene esta ideología en formas simples y relativamente puras. Una clase subordinada, en cierto sentido, no tiene sino esta ideología como su conciencia (...) o en otro sentido, esta ideología se ha impuesto sobre su conciencia -que de otro modo sería diferente- que debe luchar para sostenerse o para desarrollarse contra la ideología de la clase dominante"107. Habitualmente el concepto de hegemonía se vincula a estas definiciones, sin embargo, debe diferenciarse en lo que refiere a su negativa a igualar la conciencia con el sistema formal articulado que es la ideología. Esto no excluye los significados, valores y creencias que propaga la clase dominante, pero no se iguala con la conciencia, no se reduce la conciencia a la ideología dominante, sino que "comprende las relaciones de dominación y subordinación según sus configuraciones asumidas como conciencia práctica, como una saturación efectiva del proceso de la vida en su totalidad; no solamente de la actividad económica y política, no solamente de la actividad social manifiesta, sino de toda la esencia de las identidades y las relaciones vividas a una profundidad tal que las presiones y límites de lo que puede ser considerado en última instancia un sistema cultural, político y económico nos dan la impresión a la mayoría de nosotros de ser las presiones y límites de la simple experiencia y del sentido común". En cualquier campo de interacción, los individuos aprovechan estos diferentes tipos de recursos para lograr sus objetivos.

Para ello los individuos se basan en reglas de diversas clases. En gran medida, las reglas y convenciones que guían gran parte de las acciones de la vida social son implícitas, formales e imprecisas, y no están formuladas. La aplicación de las reglas y los esquemas, es un proceso creativo que con frecuencia implica algún grado de selección y juicio, en el cual, las reglas y los esquemas se pueden modificar y transformar en los procesos mismos. Es lo que posibilita que los individuos se orienten en el espacio social propio y que adopten prácticas acordes con su pertenencia social. "esquemas de percepción, de pensamiento, de acción" que son el resultado del trabajo de educación y de socialización al que 
está sometido el individuo y las experiencias primitivas que le pertenecen y que tienen un peso desmesurado en relación con las experiencias ulteriores. Es posible diferenciar los campos de interacción y los diversos tipos de recursos, reglas característicos: instituciones sociales: se sitúan en campos de interacción y al mismo tiempo las crean. Cualquier acción o interacción implica las ejecuciones de condiciones sociales que son características de los campos en los cuales ocurren. Esas interacciones están vinculadas con la distribución del poder en una sociedad.

En la actualidad es frecuente oír que la comunicación es una forma de acción, pronunciar una expresión es ejecutar una acción y no meramente informar o describir algún estado de cosas. Somos más sensibles al hecho de que hablar un lenguaje es una actividad social a través de la cual los individuos establecen y renuevan las relaciones que mantienen unos con otros. "Si la comunicación es una forma de acción, entonces, el análisis de la comunicación debe basarse, al menos en parte, en un análisis de la acción y en una explicación de su carácter socialmente contextualizado"108. Los fenómenos sociales pueden ser vistos como acciones con propósito llevadas a término en contextos sociales estructurados. La vida social está compuesta por individuos que llevan a cabo propósitos y objetivos de varios tipos que siempre actúan dentro de un conjunto de circunstancias previamente establecidas, y que ofrecen a los individuos diferentes inclinaciones y oportunidades.

Estas situaciones pueden pensarse como «campos de interacción», para utilizar un término desarrollado por Pierre Bourdieu ${ }^{109}$. Los individuos ocupan posiciones diferentes en el interior de estos campos, dependiendo de los diferentes tipos y cantidad de recursos disponibles para ellos. En algunos casos estas posiciones adquieren una cierta estabilidad a través de la institucionalización, esto es, convirtiéndose en parte de un paquete de reglas, recursos y relaciones sociales relativamente estables. Las instituciones pueden observarse como un determinado conjunto de reglas, recursos y relaciones con cierto grado de persistencia en el

108 THOMPSON, Jhon “Los media y el desarrollo de las Sociedades Modernas” Una Teoría de los medios de comunicación. Paidós Comunicación. Teorías Barcelona 1998 
tiempo y cierta extensión en el espacio, unidas por el propósito de alcanzar ciertos objetivos comunes. Las instituciones dan forma definitiva a campos de interacción preexistentes $y$, al mismo tiempo, crean nuevas posiciones en el interior de estos campos, así como -nuevas trayectorias para organizar la vida de los individuos que las ocupan. La posición que ocupa un individuo dentro de un campo o institución está íntimamente relacionada con el poder que él o ella poseen. De manera genérica, el poder es la capacidad para actuar de acuerdo a la consecución de los propósitos e intereses de cada uno, la capacidad de intervenir en el curso de los acontecimientos y de afectar a sus resultados. Al ejercer el poder, los individuos emplean los recursos que tienen a su alrededor; los recursos son los medios que les permiten alcanzar sus objetivos e intereses de manera efectiva. De ahí que, mediante la acumulación de recursos de varios tipos, los individuos puedan aumentar su poder, en el sentido de que, por ejemplo, un individuo podría acumular cierta cantidad de ahorros con el fin de adquirir una propiedad. Ya que los recursos pueden acumularse personalmente, con frecuencia también se acumulan dentro de la estructura institucional, que constituyen una importante plataforma para el ejercicio del poder.

Los individuos que ocupan posiciones dominantes en grandes instituciones pueden contar con inmensos recursos a su disposición, que les permite tomar decisiones y perseguir objetivos que tienen implicaciones de largo alcance. “En sentido general, el poder es un fenómeno social penetrante característico de los diferentes tipos de acción y encuentros, desde las acciones políticas visibles de los representantes del Estado hasta el mundano encuentro de individuos en la calle. Si en la actualidad asociamos comúnmente el poder con el poder político, es decir, con las acciones de individuos que actúan en nombre del Estado, es porque los Estados se han convertido en centros particularmente importantes de concentración del poder en el mundo moderno. Pero la importancia de las instituciones estatales no debería impedirnos apreciar el hecho de que el poder público político y manifiesto constituye sólo una forma de poder un tanto especializada, y que los individuos comúnmente ejercen el poder en muchos contextos que tienen poco o nada que ver con el Estado. De esta manera, ambos expresan y permiten establecer relaciones relativamente estables o redes de poder y dominio 
entre individuos, y entre grupos de individuos, que ocupan diferentes posiciones en campos de interacción"110.

Asumir que la comunicación es una forma de acción, que el proceso de comunicación debe observarse en su contexto coincide con la imposibilidad de la "neutralidad científica": "Ningún científico puede ser separado de su contexto físico y social. Toda medición modifica la realidad en el intento de registrarla.

Toda conceptualización se basa en compromisos filosóficos. Con el tiempo, la creencia generalizada en una neutralidad ficticia ha pasado a ser un obstáculo importante al aumento del valor de verdad de nuestros descubrimientos, y si esto plantea un gran problema a los científicos naturales, representa un problema aún mayor a los científicos sociales. Traducir el reencatamiento del mundo en una práctica de trabajo razonable no será fácil, pero para los científicos sociales parece ser una tarea urgente" ${ }^{111}$

Este ha sido el norte, el desafío permanente para los investigadores en comunicación en América Latina. Así como la integración espacio temporal y la articulación entre las diversas dimensiones de la problemática social. Se constituyeron en las bases de sustentación tanto axiológica como teórica de la metodología comunicacional fundamentales para "disminuir desigualdades e incrementar las diferencias entre los seres humanos"112 Autores tales como Armand Mattelart, Antonio Pasquali, Eliseo Verón, Luis Ramiro Betrán o Paulo Freire promovieron criterios de pertinencia social, una constante en el estudio latinoamericano de la comunicación. Fuentes Navarro menciona además que "es necesario afinar y extender los criterios de rigor científico que impidan caer nuevamente en los extremos discursivos ultraideologizados de los años setenta o en las sofisticadas metáforas hoy de moda... De modo que el reto prioritario para los académicos de la comunicación, en cualquier parte del mundo, al inicio del siglo XXI podría sintetizarse 
en avanzar reflexiva, y sistemáticamente en producir sentido sobre la producción social de sentido"113.

Arribamos así a una primera certeza: el campo de la comunicación en América Latina manifiesta una apertura científica y social de la investigación: "La relación comunicación/cultura es un salto teórico que presupone el peligro de desplazar las fronteras. Pero justamente de eso se trata: de establecer nuevos límites, de definir nuevos espacios de contacto, nuevas síntesis. En vez de insistir en una especialización reductora, se propone una complejidad que enriquezca"114.

\section{La Investigación en Comunicación}

La investigación es una actividad intelectual, epistemológica -peroy principalmente política. Esta emergencia del campo, se instaló en los debates de las ciencias sociales y las humanidades no sin tensiones y acuerdos. Lo anterior permitió visibilizar objetos de estudios relegados en el seno académico, pero vigentes en otros abordajes sociales. Este desafío no se llevó a cabo al margen de debates teóricos y metodológicos que permitieron rediscutir supuestos incuestionables hasta el momento. El proceso de institucionalización del campo de la comunicación en América Latina y en Argentina se refleja en el incremento de carreras de grado y posgrado; el aumento significativo de investigaciones e investigadores preocupados por estas temáticas y objetos; el número significativos de eventos académicos nacionales e internacionales; la cantidad, pero también la calidad de producciones y publicaciones que ameritan la instalación de colecciones y librerías especializadas; la articulación de distintos actores e instituciones materializadas en acuerdos y convenios de investigación y producción. El florecimiento de nuevos objetos y abordajes posibles, fragmentó la producción del conocimiento en este campo. Dicha fragmentación implicó un avance significativo pero aislado de cada subcampos de saber, de cada línea de investigación, sin evidenciar una posible integración. Es indudable que la producción de 
conocimiento en este campo creció a pasos agigantados en esto últimos años, lo que amerita generar nuevas políticas académicas que posibiliten poner en diálogo estos avances, potenciando zonas de emergencia. Resulta imperioso, entonces, intervenir en la producción del conocimiento desde un punto de vista articulador, dialógico, que potencie aún más los avances logrados. Los nuevos desafíos necesitan contar con esfuerzos mancomunados que permitan crecer en la relación de las diversas producciones al interior de la academia, pero también con las políticas públicas y las necesidades sociales, así como en la vinculación con la investigación realizada por el mercado y con el aspecto profesional de este campo de saber.

En este sentido, cabe mencionar los trabajos de Jesús Martín Barbero, preguntándose por la emergencia de lo popular en la cultura masiva de la modernidad latinoamericana, y de Néstor García Canclini sobre los modos complejos de existir de las culturas populares en el capitalismo. O las investigaciones sobre culturas urbanas llevadas adelante por Rossana Reguillo. Como también debemos nombrar el profundo análisis de las culturas contemporáneas de Aníbal Ford; las investigaciones sobre consumo cultural de María Cristina Mata; los estudios de recepción realizados por Guillermo Orozco; la propuesta de los Frentes Culturales de Jorge González; la problematización de la cultura global desarrollada por Renato Ortiz. La lista, incompleta, podría multiplicarse al infinito desafiando la idea de que para "muestra alcance un botón". Pero lo que aquí importa es señalar cómo es que no sólo hubo en América Latina un reconocimiento de los estudios culturales extranjeros sino que se hizo una reapropiación original de las herramientas teórico-metodológicas por ellos planteadas. Tan es así que para fines de los noventa tenemos en el campo de la comunicación que no sólo hay un gran número de investigaciones empíricas con claras definiciones de objetos de estudio, encaradas desde la problemática cultural como dimensión específica, sino que hay un reconocimiento internacional de una perspectiva latinoamericana al respecto.

“Desde asumir estas trayectorias, se trabajará sobre una mirada específica de la comunicación que es aquella que la liga a los procesos sociohistóricos de construcción de sentido. Parte de la perspectiva que 
atiende a la articulación entre comunicación, cultura y sociedad: la comunicación tiene que ver así con modos de estar juntos que implican unos sentidos específicos del mundo pero sobre plataformas materiales e históricas determinadas. Se constituye en escenario de transformación de la sensibilidad, de la percepción social, de la subjetividad. Deja de estar dominada por la obsesión de pensar sólo en instrumentos, para reubicar la mirada en las transformaciones de la vida cotidiana, de los modos de sentir, de ver, de conocer, de congregarse, reubicando incluso lo mediático. Pero en esta opción la cultura no es sólo reflejo de relaciones materiales -comunicación / sociedad-o dimensión simbólica aislada de la conflictividad histórica. La cultura está entendida como dimensión significante de lo social, como arena de lucha por los sentidos legítimos que una comunidad da al mundo en que vive. Así, la cultura tiene una doble dimensión: por un lado, como creación e innovación en las prácticas sociales; por otro, como terreno de dominación y reproducción. Se trata finalmente de un desarrollo dirigido al análisis de la dimensión simbólica del mundo social en términos que son a la vez históricos, sociológicos, semiológicos, estéticos y filosóficos.

La interpretación cultural, que corona los pasos descriptivos y analíticos, emerge de una conjunción de nuevas perspectivas disciplinarias que interesan tanto a la investigación académica como a la intervención en la esfera pública, los medios de comunicación y las instituciones. La investigación sociocultural se presenta así como un lugar de encuentro de diferentes propuestas teóricas y metodológicas. La discusión teórica sobre el mundo social, la exposición de métodos de análisis y el diseño de investigaciones, serán los ejes sobre los cuales el programa pone particular énfasis.

\section{Es así como aparecen nuevos enfoques, objetos y problemas}

- La relación entre la cultura masiva y la popular, no como dos formaciones que se oponen sino a partir de su mutua imbricación y problemático mestizaje.

- Medios, exclusión y construcción social de sentido.

- Los usos sociales de los medios y las llamadas teorías de la recepción: la mediación cultural; el consumo cultural; los frentes culturales. 
- La memoria: los mapas de los silencios.

- Comunicación/ identidades: los nuevos/viejos actores: los movimientos sociales; los jóvenes.

- Las formas de habitar las territorialidades: la ciudad; lo global/local; la intersubjetividad y lo virtual.

- Los nuevos/viejos planteamientos teórico-metodológicos y la construcción de objetos en América Latina"115.

La producción de conocimiento en torno a las problemáticas sociales, históricas y políticas aparece hoy como un eje central en el desarrollo de las ciencias sociales. En la última década se ha expandido, tanto en Europa como en América, el área de cuestiones que globalmente pueden clasificarse como propias de la comunicación / cultura / sociedad: por una parte, el estudio de las instituciones u organizaciones civiles y estatales, y sus prácticas y actores; por la otra, el análisis de la producción de sentidos en las culturas letrada, popular y electrónico-audiovisual atravesadas por la modernidad, en un principio, y la globalización, más acá en el tiempo; finalmente, la investigación de los efectos sociales de la circulación de los mensajes y bienes simbólicos. Sin exageraciones, puede afirmarse que actualmente una de las perspectivas más dinámicas de las ciencias sociales y humanas es la que se ha desarrollado en este campo de estudios. Y este dinamismo proviene no sólo del carácter innovador de los métodos -de la semiología al análisis cultural, del estudio del imaginario social al de los medios de comunicación masivos-, sino también de los aportes que los estudios culturales de inspiración sociológica, antropológica y semiológica han realizado a la teoría social y específicamente al campo de la comunicación.

Consideramos que el Estado a través en este caso de la Universidad Pública, es un actor central en la generación de profesionales que puedan hacer de la investigación un territorio de producción de conocimientos atento a las demandas de la sociedad toda. La investigación es una actividad intelectual, epistemológica -pero- y principalmente política. Esta línea se promueve así como un espacio de indagación y producción 
que favorezca el conocimiento científico sobre nuestras sociedades, y promueva la implementación de acciones que ayuden a su transformación, ofreciendo herramientas de investigación y análisis de la realidad sociocultural de nuestros países.

En referencia a las acciones para la transformación Rolando García ${ }^{116}$ plantea: “En primer lugar, hay algunas formas muy obvias, que han imperado en toda la historia de la ciencia, de nacionalismos o de concepciones de ciertas clases o grupos que han impuesto la manera de hacer ciencia en una época determinada. En mecánica de fluido por ejemplo, los ingleses se aferraron a las ideas de Newton -casi todas falsas- e ignoraron durante muchos años los brillantes trabajos de John y Daniel Bernoulli o de Euler, simplemente porque era la ciencia "del continente". Este es un hecho muy conocido y no vale la pena detenerse en él, cuando se habla de la influencia de la ideología en la ciencia. Pero hay otro sentido, mucho más profundo, de considerar la influencia de la ideología -yo diría, más bien, de la concepción del mundo- en el desarrollo de la ciencia. Si los chinos, que descubrieron el principio de inercia 2.000 años antes de Galileo, hubieran continuado desarrollando las ideas físicas que tenían en la época en que el mundo occidental estaba dominado por Aristóteles, es muy posible que la física actual fuera bien distinta. Los hechos no están ahí, dados de una vez por todas; hay toda una concepción del mundo que va involucrada en su elección y en la manera de tratarlos...

Sin embargo, esto difícilmente lo hace un conjunto de hombres reunidos alrededor de una mesa, y estudiando mucho. Creo que es algo que se da a través de procesos históricos y no por la acción directa de un individuo que por razones de convicción decide hacer otro tipo de ciencia. Si las consideraciones precedentes tienen algo más que el valor de una

116 Rolando García maestro (1936) y de Profesor Normal en Ciencias (1939). Estudió Física y Matemáticas en la Universidad de Buenos Aires, durante tres años. Entre 1946 y 1949, estudió en las Universidades de Chicago y California. En esta última obtuvo los títulos de Master of Arts y Doctor of Philosóphy. Paralelamente, ha realizado estudios de Filosofía (en particular, de Lógica Simbólica, Semántica y Filosofía de la Ciencia- Profesor de Lógica y Filosofía en la Universidad de La Plata, de Mecánica de Fluidos y de Metereología Dinámica en la Facultad de Ciencias Exactas y Naturales de la Universidad de Buenos Aires, desde 1957 hasta su renuncia en 1966, período durante el cual fue también Decano. Miembro del Directorio del CONICET, fue Vicepresidente desde su fundación, en 1957, hasta 1964. Desde 1967, es miembro del Centro Internacional de Epistemología Genética, que dirige el Profesor Jean Piaget. 
especulación puramente académica es, a mi juicio, por sus implicaciones prácticas para la acción. Lo que nos preocupa es qué es lo que podemos hacer nosotros -trabajadores en el campo científico- para ser coherentes con nuestra concepción del tipo de sociedad al cual aspiramos. Creo que los problemas que tenemos por delante están dados ya de cierta manera. Estamos inmersos en un mundo que nos conduce a pesar nuestro. Tenemos que conocer y dominar ese mundo y no podemos tomar como actitud revolucionaria legítima el retirarse a replantear la formulación de la ciencia o a buscar la ciencia (que habrá de implantarse cuando se transforme la sociedad). Dentro de la perspectiva de lucha que se abre para nosotros, lo que importa es la manera de estar involucrados en un proceso que nos impone la urgencia de actuar con él, dentro de él, y no marginados, observándolo desde afuera"117.

Entonces: ¿qué podemos hacer nosotros, cuáles son nuestros desafíos?, ¿deberíamos revisar los objetos y objetivos de las investigaciones? ¿Cómo nos involucramos, como actuamos desde adentro? Desde la Universidad Pública, en la Facultad de Periodismo y Comunicación Social de la UNLP en la Argentina del 2014 ¿en qué consisten los aportes de nuestras producciones?. 


\section{De la Convergencia tecnológica a los saberes compartidos}

"Todo lo que sabemos lo sabemos entre todos"

Juan De Mairena ${ }^{118}$

Como primera caracterización de la convergencia tecnológica destacamos la posibilidad que permite la digitalización de la información. Este proceso permite transformar al lenguaje binario, ceros y unos, todo tipo de información analógica. Las imágenes, las imágenes en movimiento, el texto impreso: libros, bibliotecas, los sonidos, los audiovisuales, a través de la digitalización, circulan, se editan se consumen y se almacenan traducidos en bits. Podemos afirmar que el proceso de digitalización habilita la convergencia tecnológica y permite que en un mismo soporte contenga músicas, textos, films, series, fotos, pinturas, esculturas, murales, voces, etc.

El otro factor tecnológico que potencia la convergencia es la red de redes: internet es un conjunto descentralizado de redes de comunicación interconectadas que utilizan la familia de protocolos TCP/IP119, lo cual garantiza que las redes físicas heterogéneas que la componen funcionen como una red lógica única, de alcance mundial. Sus orígenes se remontan a 1969, cuando se estableció la primera conexión de computadoras, conocida como Arpanet, entre tres universidades en California y una en Utah, Estados Unidos. Uno de los servicios que más éxito ha tenido en Internet ha sido la World Wide Web (WWW), a tal punto que es habitual la confusión entre ambos términos. La WWW es un conjunto de protocolos que permite, de forma sencilla, la consulta remota de archivos de hipertexto. Esta fue un desarrollo posterior (1990) y utiliza Internet como medio de transmisión ${ }^{120}$.

118 DE MAIRENA Juan (Antonio Machado leyendo en prosa) Citado por Martín Barbero, Jesús. http://www.cubadebate.cu/ opinion/2009/11/10/todo-lo-que-sabemos-lo-sabemos-entre-todos/

119 El modelo TCP/IP es un modelo de descripción de protocolos de red desarrollado en los años 70 por Vinton Cerf y Robert E. Kahn. Fue implantado en la red ARPANET, la primera red de área amplia, desarrollada por encargo de DARPA, una agencia del Departamento de Defensa de los Estados Unidos, y predecesora de la actual red Internet. EL modelo TCP/IP se denomina a veces como Internet Model, Modelo DoD o Modelo DARPA.

120 Oxford English Dictionary (Draft edición), March 2009, consultado el 26 October 2010, «Shortened INTERNETWORK n., perhaps influenced by similar words in -net» 
Combinados, la digitalización de la información junto a las infinitas posibilidades de información que brinda internet (más la fibra óptica, los satélites, los dispositivos móviles, de alta resolución, etc. generan la convergencia tecnológica. "Desde el punto tecnológico, las redes de comunicación, las redes de ordenadores y las redes de radio y televisión convergieron gracias a las redes digitales, las nuevas tecnologías de transmisión y almacenamiento de datos, en particular la fibra óptica, las comunicaciones por satélite y el software avanzado" ${ }^{\prime 21}$. El Profesor Henry Jenkins ${ }^{122}$, complejiza el concepto: "es el flujo de contenidos a través de múltiples plataformas mediáticas. Es proceso, no es punto final, implica cambios tecnológicos, industriales, culturales, culturales, en función de quienes hablan de aquello a lo que creen estar refiriéndose. La convergencia se produce en el cerebro de los consumidores individuales, mediante sus interacciones sociales con otros. Convergencia es una palabra que logra describir los cambios tecnológicos, industriales, culturales y sociales en función de quienes hablen y de aquello a lo que crean estar refiriéndose"123. Por lo tanto, se muestra contrario a la idea de que la convergencia debería concebirse, principalmente, como un proceso tecnológico que aglutina múltiples funciones mediáticas en los mismos aparatos. Para este autor, la convergencia "representa un cambio cultural, toda vez que se anima a los consumidores a buscar nueva información y establecer conexiones entre contenidos mediáticos dispersos"124. Por lo tanto, la convergencia, según Jenkins, no tiene lugar en aparatos mediáticos, sino que se produce en el cerebro de los consumidores individuales y mediante sus interacciones sociales con otros. Este autor señala que, en ocasiones, las nuevas empresas mediáticas han hablado de la convergencia para referirse a que los viejos medios serían absorbidos por completo en la órbita de las tecnologías emergentes. Para Jenkins "el proceso de digitalización estableció las condiciones para la convergen-

121 ARONSON Jonathan D F y. COWHEY Peterand. "Transforming Global Information and Communication Markets" The Political Economy of Innovation The MIT Press Cambridge, Massachusetts London, England 2009

122 JENKINS, Henry es sociólogo estudioso de la cultura popular, en particular la norteamericana. Co-Director of the MIT Comparative Media Studies

123 JENKINS, Henry," Convergence culture. La cultura de la convergencia de los medios de comunicación", Barcelona, Paidós, 2008. 
cia; los conglomerados corporativos la convirtieron en un imperativo"125. El sociólogo,Manuel Castells, ${ }^{126}$ también se muestra de acuerdo con la postura de Jenkins al apuntar que la convergencia en la comunicación no es solo tecnológica y organizativa, aunque éstas sean dimensiones clave que crean la base material para el proceso de convergencia más amplio. La convergencia es fundamentalmente cultural, y se produce, en primer lugar, en las mentes de los sujetos comunicadores que integran varios modos y canales de comunicación en sus costumbres y en su interacción"127.

\section{Comunicación y Convergencia}

Tal como ya fue dicho, entendemos la comunicación desde una mirada que no la limita a los medios, sino que la piensa en las prácticas, en las producciones de sentido. La comunicación imbricada a la cultura, la comunicación no como una disciplina, sino como un objeto en construcción desde distintos saberes. Asumimos, por lo tanto la perspectiva sociocultural de la comunicación que permite ver los procesos sociales, las luchas por el sentido. Atravesamos un contexto en el que múltiples prácticas comunes de la cultura han comenzado a digitalizarse. Esto ha dado origen a una serie de experiencias que proponen otros modos de producir, circular y almacenar el conocimiento. Aquellas categorías que inicialmente la imprenta transformó se encuentran ahora atravesadas por la digitalización. Las Tecnologías de la Comunicación y la información y la web 2.0 están cada vez más presentes en la vida cotidiana, constituyen nuevas formas de sociabilidad y de construcción del espacio público. En este marco, la comunicación y los modos de producción de bienes simbólicos, necesariamente se transforman. Es importante señalar que las tecnologías de comunicación que nos permiten hoy hablar de la mediatización de la cultura surgieron en un contexto de transformación en los modos de organización social.

125 JENKINS, 2008:22 Op Cit

126 CASTELLS, Manuel sociólogo y profesor universitario de Sociología y de Urbanismo en la Universidad de California en Berkeley.Director del Internet Interdisciplinary Institute en la Universidad Abierta de Cataluña y presidente del consejo académico de Next International Business School. Según el Social Sciences Citation Index 2000-2009, Es el quinto académico de las Ciencias Sociales más citado del mundo y el académico de las Tecnologías de la Información y la Comunicación (TIC) más citado del mundo.1

127 CASTELLS, Manuel “COMUNICACION Y PODER”, ALIANZA EDITORIAL, 2009 ISBN 9788420684994 Madrid 2009.

DeFINICIONES. EJes SOBRE LA CALIDAD DE LOS ENCUADRES $\mid$ 
A los fines de esta investigación, Internet será pensada en tanto espacio de vinculación e intercambio. Nos posicionamos desde una mirada que entiende las tecnologías como instituciones sociales, que surgen en un contexto al que modifican y por el que son modificadas. Desde nuestro marco teórico, las tecnologías no son concebidas en tanto instrumentos o canales, vaciadas de espesor cultural y político, sino todo lo contrario: son entendidas como espacios cargados de sentido social y cultural. Las potencialidades de la web están transformando la producción del conocimiento, los están redefiniendo, reformulando. Como así también están transformando otras instituciones, que ya estaban atravesadas por las lógicas de los medios pero que ahora se ven implicadas en una revolución tan profunda que, como dijimos antes, podría ser comparada a la que produjo el surgimiento de la imprenta en el siglo XV. Las tecnologías e Internet habilitan la autogestión, la autoproducción y posibilitan la creación desde lenguajes transmediales. En términos de Jenkins, lo transmedial se relaciona a la convergencia mediática: «Convergencia» es una palabra que logra describir los cambios tecnológicos, industriales, culturales y sociales en función de quiénes hablan y de aquello a lo que crean estar refiriéndose".

Este nuevo espacio de intercambio y relación que se abre debe ser pensado y analizado a la luz del contexto que lo atraviesa y teniendo en cuenta, además, que, si bien la web 2.0 propone una transformación más profunda en los modos de producir, distribuir y consumir los llamados bienes simbólicos, una nueva etapa en el proceso de mediatización de la cultura, no agota otros espacios de participación, ni tampoco puede ser pensada como la panacea de la era digital. Entendemos las tecnologías y sus usos desde un pensamiento complejo que no se reduce a la linealidad determinista de la causa- efecto, desde este marco de comprensión es que reconocemos que existen diferentes usos, apropiaciones y distintos accesos a estas nuevas tecnologías. Las transformaciones nunca se dan de manera uniforme y es esa diversidad, el intento de comprenderla (y también las desigualdades que a partir de los diferentes usos se producen), lo que moviliza nuestra investigación. Así como la imprenta produjo cambios profundos e irreversibles en los modos de producir y distribuir lo cultural, creemos que la web 2.0 (con sus alcances y limitaciones) está produciendo una nueva transformación 
en los modos de estar y representarnos el mundo. En primer lugar, produce un desdibujamiento entre productores y receptores; permite que los contenidos circulen y se conserven digitalizados, pero también permite que puedan ser modificados, transformados de una manera más fácil: acceder a fragmentos de películas, de canciones, de textos para, no sólo ponerlos a circular, sino también producir nuevas propuestas, nuevos productos a partir de los ya existentes.

La web 2.0 propone un espacio de producción más colaborativo, las experiencias wikis son un ejemplo en este sentido, y al mismo tiempo abre a nuevas posibilidades de socialización y participación. Las tecnologías de comunicación que nos permiten hoy hablar de la mediatización de la cultura surgieron en un contexto de transformación en los modos de organización. Los cambios en la división del trabajo y en los modos de producción han llevado a que la obra de arte sea tratada como mercancía. Es en este momento donde aparece el debate por la industria cultural, entendida como "conjunto de actividades relacionadas directamente con la creación, la fabricación, la comercialización y los servicios de productos o bienes culturales en el ámbito de un país o a nivel internacional"128. La industria cultural es la industria de los bienes simbólicos, es aquella dedicada "a producir y comercializar con criterios industriales bienes y servicios destinados específicamente a satisfacer o promover demandas culturales con fines de reproducción ideológica, económica y social" ${ }^{129}$.

Como señalábamos más arriba las potencialidades de la web 2.0 están transformando a las industrias culturales, las están redefiniendo, reformulando. Como así también están transformando otras instituciones, que ya estaban atravesadas por las lógicas de los medios; pero que ahora se ven implicadas en una revolución tan profunda que, quizás, podría ser comparada a la que produjo el surgimiento de la imprenta en el siglo XV. Es esa revolución lo que pretendemos investigar y por eso necesitamos pensar y analizar la web 2.0 desde su interrelación con

128 GETINO, Octavio "Las industrias culturales en el MERCOSUR: apuntes para un proyecto de políticas de Estado" en Industrias Culturales: mercado y políticas públicas en Argentina; Ciccus; Buenos Aires. (2003), 
diversas instituciones: la política, la educación, las industrias culturales y los medios, para reflexionar también en torno a cómo esas transformaciones afectan la cotidianidad de los sujetos, sus modos de estar y representarse el mundo. Retomando a Williams podríamos plantear que "el complejo de sentidos (sobre la cultura) indica una argumentación compleja sobre las relaciones entre el desarrollo humano general y un modo determinado de vida; y entre ambos y las obras y prácticas del arte y la inteligencia"130. Una trama cultural que se organiza en términos de tradiciones, instituciones y formaciones y que se da también en la lucha, el conflicto y las relaciones entre elementos dominantes, residuales y emergentes.

La mirada comunicacional está, entonces, en reconocer las negociaciones, las luchas de sentido, en pensar las significaciones que se hacen en torno a lo que se entiende por arte, por producción cultural y del conocimiento en un contexto que transforma aún más los modos de producción, circulación y consumo. Estas experiencias, salen a disputar los sentidos establecidos, los significados instituidos en torno al saber, el conocimiento, la comunicación. Con sus prácticas ponen de manifiesto la posibilidad de otros modos de pensar los modos de producir conocimiento. Analizar estas prácticas que, en términos de Williams, podríamos pensar como emergentes, constituye un punto nodal del análisis comunicacional. Como explica el maestro Héctor Schmucler "La comunicación no es todo pero debe ser hablada desde todas partes: debe dejar de ser un objeto constituido para ser un objetivo a lograr. Desde la cultura, desde el mundo de símbolos que los seres humanos elaboran con sus actos materiales y espirituales, la comunicación tendrá sentido transferible a la vida cotidiana"131.

La clave es entonces pensar qué acontece con la comunicación en este nuevo escenario tecnológico. Porque las nuevas tecnologías generan cambios, crisis "es una crisis del lenguaje, de los modos de comunicación, del periodismo con sus públicos, porque hay otros públicos, hay

130 WILLIAMS, RAYMOND (1992); “Tecnologías de la comunicación e instituciones sociales”; en Historia de la Comunicación. Vol.2. De la imprenta a nuestros días; Barcelona; Bosch Casa Editorial, S.A. 
otros lenguajes, otras escrituras y el asunto no es tecnológico."132 Coincidimos aquí con Martín Barbero en el diagnóstico de crisis y cambios que no son tecnológicos, o no son sólo de índole tecnológica. Fundamenta su afirmación con una cita de Benjamín "que llamó -y utilizó una palabra griega- un cambio de sensorium ${ }^{133}$, un cambio de la sensibilidad colectiva, de los modos de percibir el espacio, el tiempo, lo próximo, lo lejano; lo viejo, lo nuevo, que yo relaciono mucho con la idea que tuvo Gramsci de la crisis. Éste entendía una crisis como un momento en el que algo clave, decisivo, estaba muriendo y lo nuevo no acababa de nacer, no tenía forma todavía. Creo que es una espléndida caracterización de la crisis. Algo está claramente perdiendo su vigencia, sus valores, su autoridad, pero lo nuevo no está claro, no sabemos, no tiene figura, como tenía lo viejo"134. Podemos reconocernos en estos tiempos de transición, de agonías y nacimientos, de profundos cambios en los modos de percibir, cambios en los lenguajes y en las escrituras; en los modos de producción, de circulación, de apropiación y de edición. Cambios en los relatos y en los modos de narrar. Hibridaciones y neologismos se sintetizan en bits, con la consecuente alteración de las nociones de tiempo y espacio, las tecnologías nos habilitan la inmediatez, la experiencia simultánea y lejana a la vez.

"La riqueza que hace posible esta experiencia es internet: que es una figura, no es la tecnología. Es la posibilidad de que lo mejor que ha producido el ser humano en todos los ámbitos deje de ser de unos pocos, deje de ser de los que saben escribir, deje de ser de los que saben pintar para ser un derecho de todos. Evidentemente es una revolución, es una mutación de sensibilidad y es una mutación de percepción, y por tanto de lenguajes y de escrituras Internet es inteligencia colectiva: So-

132 MARTIN BARBERJO, Jesús "Todo lo que sabemos, lo sabemos entre todos" http://www.cubadebate.cu/opinion/2009/11/10/todo-lo-que-sabemos-lo-sabemos-entre-todos.

133 El concepto de sensorium fue introducido en la obra de Walter Benjamin, filósofo alemán de la primera mitad del siglo $\mathrm{XX}$, en la que se consignan los estudios llevados a cabo por este autor sobre estética y técnica, entre otros temas. El concepto resume la metodología con la que fueron estudiados los fenómenos estéticos, el papel de la técnica en sus desarrollos y transformaciones, y a su vez las relaciones que de allí se derivaban con la política, el arte, la economía y la organización social.

134 MARTIN BARBERJO, Jesús " Todo lo que sabemos, lo sabemos entre todos" http://www.cubadebate.cu/opinion/2009/11/10/todo-lo-que-sabemos-lo-sabemos-entre-todos Op Cit. 
ciedad de los saberes compartidos, saber es más que información y conocimiento, saber es la utopía de futuros a largo plazo"135. Es la posibilidad de estallar los sentidos del arte único creado para ser contemplado en museos, se multiplican y resignifican en nuevos ámbitos y circunstancias. Se inventan lenguajes propios a partir de las nuevas tecnologías, de las nuevas sensibilidades. "Las nuevas tecnologías nos permiten pensar en lo que instauran en la relación social, lo que las nuevas tecnologías nos permiten pensar, no lo que ellas hacen, no en términos de lo que producen las nuevas tecnologías en sí, sino de lo que instauran en la relación social, ese tipo de sensorium" ${ }^{\prime 136}$. Se trata de una nueva experiencia cultural, nuevos modos de percibir y de sentir, de oír y de ver, una nueva sensibilidad colectiva. La comunicación dejó de ser lo que apago y enciendo; es algo que empieza a configurarme como sujeto, como ciudadano, como consumidor, hoy día nos damos cuenta de que el concepto de red acabó con el concepto de transmisión. “En la red, dónde está el emisor hoy día. La red nos dice que es mucho más efectivo un montón de pequeños grupos bien conectados, que un grupo grandísimo. Esta es la nueva teoría de la comunicación. Antes requeríamos de grandes máquinas, de grandes aparatos, ahora vamos aprendiendo con otras tecnologías"137. Ahora tenemos la red de redes, con nodos y enlaces que habilitan innovadores modos de producir saberes. Cargadas de un potencial sociocultural, presentes en la cotidianeidad de los sujetos las redes nos invitan a asociarnos y producir sentidos con otras dinámicas. Para comprender este proceso recurrimos a Henry Jenkins en su libro "La cultura de la convergencia de los medios de comunicación" plantea tres ejes fundamentales para interpretarla: la convergencia es un cambio cultural, al animar a los consumidores a buscar nueva información y a establecer conexiones entre contenidos mediáticos dispersos; la cultura participativa es el término que engloba esta nueva forma de coproducir mediaciones. La convergencia se produce en nuestras ca-

135 MARTIN BARBERJO, Jesús "Todo lo que sabemos, lo sabemos entre todos" http://www.cubadebate.cu/opinion/2009/11/10/todo-lo-que-sabemos-lo-sabemos-entre-todos Op Cit

136 MARTIN BARBERJO, Jesús "Todo lo que sabemos, lo sabemos entre todos" http://www.cubadebate.cu/opinion/2009/11/10/todo-lo-que-sabemos-lo-sabemos-entre-todos Op Cit

137 MARTIN BARBERJO, Jesús "Todo lo que sabemos, lo sabemos entre todos" http://www.cubadebate.cu/opinion/2009/11/10/todo-lo-que-sabemos-lo-sabemos-entre-todos Op Cit 
bezas y en nuestras interacciones sociales y la inteligencia colectiva que es el proceso social de adquisición del conocimiento: es dinámico y participativo, comprobando y reafirmando continuamente los lazos sociales del grupo.

\section{Cultura Participativa}

- Los consumidores exigen que las empresas mediáticas se muestren más receptivas a sus gustos e intereses.

- El derecho a participar en la cultura se considera la libertad que nosotros mismos nos hemos otorgado.

- La capacidad de participar no proviene de destruir la cultura comercial sino de escribir sobre ella, modificarla, corregirla, expandirla, conferirle una mayor variedad de perspectivas y luego volver a ponerla en circulación.

- La cultura participativa mueve su punto de mira de la educación del individuo hacia el desarrollo de la sociedad que se involucra. Los nuevos educados, casi todos, incorporan habilidades sociales desarrolladas por medio de la colaboración y el desarrollo de redes. Estas habilidades están construidas sobre los cimientos de la educación tradicional, investigación, habilidades técnicas y el análisis crítico enseñados en la sala de clases.

\section{Estas nuevas habilidades incluyen:}

a) Juego: La capacidad de experimentar con su entorno como una forma de solución de problemas, a través de actividades lúdicas.

b) Actuación: La habilidad de adoptar diferentes identidades con el objeto de ejercitar la improvisación y el descubrimiento.

c) Simulación: La habilidad de interpretar y construir modelos dinámicos de procesos que reproduzcan el mundo real.

d) Apropiación: La habilidad de sopesar significativamente (con sentido ético) y mezclar el contenido de los medios.

e) Multitarea: La habilidad de poder observar con detenimiento el entorno y poderse enfocar sobre los detalles más importantes del mismo. 
f) Conocimiento distributivo: La habilidad de interactuar significativamente con herramientas que desarrollan las capacidades mentales.

g) Inteligencia Colectiva: La habilidad de poder agrupar conocimiento y comparar notas con otros para el logro de una meta u objetivo común.

h) Juicio: La habilidad de evaluar la credibilidad y confianza de las diferentes fuentes de información (sentido crítico).

i) Navegación: La habilidad de seguir un flujo de historias e información a través de diversos medios.

j) Creación de Redes: La habilidad de buscar, sintetizar, y distribuir la información.

k) Negociación: La habilidad de viajar a través de diferentes comunidades, discerniendo y respetando diferentes perspectivas a la vez de captar y seguir normas alternativas ${ }^{138}$.

\section{Inteligencia Colectiva}

- "En Internet, sostiene Pierre Lévy"139, la gente aprovecha sus conocimientos individuales en pro de metas y objetivos compartidos: "Nadie lo sabe todo, todo el mundo sabe algo, todo conocimiento reside en la humanidad". La inteligencia colectiva se refiere a esa capacidad de las comunidades virtuales de estimular la pericia combinada de sus miembros. Lo que no podemos saber o hacer por nosotros mismos, puede que seamos ahora capaces de hacerlo colectivamente. $Y$ esta organización de los usuarios y espectadores en lo que Lévy denomina "comunidades de conocimientos" les permite ejercer un poder total mayor en sus negociaciones con los productores mediáticos.

- La emergente cultura del conocimiento jamás eludirá del todo la influencia de la cultura mercantil, como tampoco ésta puede funcionar totalmente al margen de las constricciones del Estado-nación. Lévy su-

138 JENKINS, Henry. Op Cit

139 LÉVY, Pierre: es uno de los filósofos más importantes que trabaja en las implicaciones del ciberespacio y de la comunicación digital. En 1990 publicó un libro acerca de la convergencia de redes digitales y la comunicación hipertextual. Henry Jenkins se refiere a él como una autoridad importante de las teorías de inteligencia colectiva en línea. Actualmente profesor en el Departamento de Comunicación de la Universidad de Ottawa. De 1993 a 1998 fue profesor en el Departamento Hipermedia de la Universidad de París VIII. Sus intereses están situados alrededor del concepto de inteligencia colectiva1 y en el de sociedades basadas en el conocimiento. 
giere, sin embargo, que la inteligencia colectiva alterará gradualmente las formas de operar de la cultura mercantil. El pánico de la industria a la participación de la gente se le antoja a Lévy corto de miras: "Al impedir que la cultura del conocimiento llegue a ser autónoma, despojan a los circuitos del espacio mercantil [...] de una extraordinaria fuente de energía". La cultura del conocimiento, sugiere, actúa como "motor invisible e intangible" para la circulación e intercambio de mercancías. La nueva cultura del conocimiento surge a medida que nuestros vínculos con formas previas de comunidad social se van rompiendo, nuestro arraigo en la geografía física disminuye, nuestros lazos con la familia extensa e incluso nuclear se desintegran y nuestras lealtades a los Estados-nación se redefinen. No obstante, surgen nuevas formas de comunidad: estas nuevas comunidades se definen mediante afiliaciones voluntarias, temporales y tácticas, reafirmadas en virtud de empresas intelectuales e inversiones emocionales comunes.

- Los miembros pueden cambiar de grupo cuando varían sus intereses y necesidades, y pueden pertenecer a más de una comunidad a la vez. Estas comunidades, sin embargo, se mantienen unidas mediante la producción mutua y el intercambio recíproco de conocimientos. Como escribe Lévy, tales grupos "hacen accesible al intelecto colectivo todo el conocimiento pertinente disponible en un momento dado". Lo que es más importante, sirven como sedes para "la discusión, la negociación y el desarrollo colectivos", y estimulan a los miembros individuales para que busquen nueva información para el bien común: “Las preguntas no respondidas generarán tensión [...] indicando las regiones donde se precisa invención e innovación".

- Podríamos entender esta discusión en términos de la distinción entre la noción de inteligencia colectiva de Pierre Lévy y lo que Peter Walsh ha descrito como "el paradigma del experto". Walsh sostiene que nuestros supuestos tradicionales sobre la pericia y el conocimiento se están derrumbando, o al menos transformando, en virtud de los procesos más abiertos de comunicación en el ciberespacio. El paradigma del experto requiere un cuerpo definido de conocimientos que puede dominar un individuo. Las clases de cuestiones que prosperan en una inteligencia colectiva, sin embargo, son abiertas y profundamente in- 
terdisciplinares; se deslizan rebasando los límites y hacen uso de los conocimientos combinados de una comunidad más diversa.

- "En una situación continuamente cambiante, los lenguajes oficiales y las estructuras rígidas no hacen más que desdibujar o enmascarar la realidad". Lo que mantiene unida una inteligencia colectiva no es la posesión de conocimientos, que es relativamente estática, sino el proceso social de adquisición del conocimiento, que es dinámico y participativo, comprobando y reafirmando continuamente los lazos sociales del grupo, señala Lévy. ${ }^{140}$ 


\section{Prácticas y saberes operantes}

Aquí presentamos los "resultados" con que hago las cuentas de lo curricular, en tres grandes parágrafos: en primer lugar, retomo el palimpsesto de lo curricular que ya nos institucionaliza; luego especifico lo acontecimental de los sujetos de educación con que me encuentro en las aulas concretas de mi desarrollo profesional; $y$, por último, vuelvo a problematizar la calidad del encuadre sistémico y presento algunos ejes que preavisan la conclusión necesaria hacia una propuesta integral, crítica, política.

\section{Entonces, lo curricular}

Todo el cambio institucional formal también permitió incorporar la discusión no sólo por la formación sino también por las opciones frente a tensiones que conformaron el campo desde el mismo origen de los estudios en periodismo y comunicación en América Latina: lo tecnológico versus la cultura, la lógica de la Modernidad y el desarrollismo frente a la de las Memorias y las Identidades.

Veníamos de una modificación del Plan de Estudios 1977 (Periodismo y Licenciatura en Comunicación Social), síntesis específica del proyecto político ideológico de la Dictadura cívico-eclesiástico-militar autodenominada "Proceso de Reorganización Nacional" y que, entre otros "matices" basaba una buena parte de su estructura en formar para el control de los públicos mediante el "aparato" ideológico de los medios. El Plan resultante, el "1989", ampliaba los alcances de la Carrera e incorporaba una nueva concepción de la Comunicación, con la orientación Planificación Institucional. Dividida en un Ciclo Básico de tres años y en un Ciclo Superior de dos, con las orientaciones Periodismo y Planificación Institucional y Comunitaria, se completaba la Licenciatura en Comunicación Social. 
Al culminar el primer ciclo de desarrollo curricular, en 1994, con el egreso de la primera promoción de Licenciados con dichos títulos orientados, y cumpliendo lo que el mismo plan estipulaba, el Consejo Académico consideró necesario evaluar el impacto de éste en la formación profesional y definir los objetos de transformación en torno a los cuales iniciar un nuevo proceso de reforma curricular.

La posibilidad de llegar a ser Facultad también fundaba la discusión sobre lo que tenía que ser la Carrera desde ese momento y el proceso de autoevaluación curricular abarcó diferentes y variadas instancias productivas: jornadas de debate públicas e interclaustros, comisiones ad hoc de los órganos del cogobierno, análisis de las políticas de formación en Comunicación Social y de diferentes curriculas y Planes de Estudios de la especialidad, realización de encuestas como elemento diagnóstico, destinadas a recoger las opiniones de Estudiantes, Profesores y Graduados, espacios permanentes de intercambio de análisis y propuestas con diferentes sectores y organismos de la Facultad y la Universidad, reflexiones sobre la práctica curricular con Docentes Auxiliares en el marco de los Cursos de Capacitación Docente, realización de Seminarios de Intercambio Académico con especialistas en el área, realización de Talleres de Prácticas Profesionales con graduados de las dos Orientaciones y evaluaciones externas realizadas por expertos. Las razones institucionales de la reforma del Plan de Estudios estuvieron fuertemente vinculadas con la generación de un marco normativo que permitiera recuperar las prácticas curriculares instituyentes. Esto significa que lo que apareció como consenso fue la realización de una reforma curricular y no sólo de un cambio de Plan de Estudios. Así, sus alcances comprometen el proyecto institucional de formación de comunicadores, las diversas actividades y alternativas pedagógicas y los contenidos que las sostienen.

La reforma del Plan por sí sola implicaría avances precederos si no involucrara, fundamentalmente, el hacer docente, y la totalidad de las prácticas institucionales de formación. La reforma curricular es engobladora del hacer institucional de modo que comprende la política académico-institucional de la Facultad de Periodismo y Comunicación Social, sosteniendo su identidad, fuertemente ligada a la práctica profesional, y profundizando en otros campos comunicacionales. Cabe destacar que 
este proceso se inscribió en el marco de la modificación institucional que supuso el pase de Escuela a Facultad. La velocidad de las transformaciones sociales en el mundo de alta complejidad global impone categorías diversas a la hora de pensar un currículum que se ocupe de formar Comunicadores Sociales para el próximo milenio. La complejidad de la cultura actual obliga a desentrañar los problemas desde múltiples miradas, dando forma a los discursos interdisciplinarios que han tomado consistencia en las últimas décadas, en el fin de un siglo marcado por la reorganización del conocimiento y la incipiente ruptura de las fronteras disciplinarias. Esta complejidad en el campo comunicacional aparece caracterizada por la continuación de nuevos campos localizados en los bordes de disciplinas de las Ciencias Sociales, otorgando a las prácticas y estudios comunicacionales una dimensión interdisciplinaria y transdisciplinaria. Ciertamente que las posibilidades que otorgaban la estructura y organización del Plan de Estudios 1989, de marcado corte escolarizado, constituía un obstáculo fundamental para el desarrollo de estas perspectivas.

Las transformaciones que inicia la era posindustiral son en realidad una totalidad. Abarcan el conjunto de los órdenes de la vida. Comprender sus consecuencias a la hora de pensar en los diseños curriculares en una Carrera de Comunicación era inevitable, para sopesar así las características de ese impacto en los distintos niveles del pensar y actuar humanos, De ahí que sea importante avizorar, al menos tentativamente, cuáles son los signos de este nuevo mapa de la realidad, que desde lo tecnológico, lo cultural, lo social, lo político, serán el horizonte de los comunicadores y de su formación.

Realizado este diagnóstico y mediante un minucioso trabajo por parte de los expertos ocupados en diseñarlo respetando los consensos construidos en distintas instancias, el nuevo Plan, aún hoy vigente, define como Objetivos y Perfiles de Formación ${ }^{141}$ : 


\section{a) Del Licenciado en Comunicación Social:}

El objeto de estudio de la Carrera, en ambas Orientaciones: Periodismo y Planificación Comunicacional, comprende los procesos de comunicación protagonizados por agentes sociales: procesos que abarcan todas las formas comunicativas: desde las interpersonales hasta las masivas, mediadas o no tecnológicamente.

El perfil común de la formación, en sus diferentes Orientaciones, es el de un Productor de Comunicación, un agente productor de hechos y procesos socioculturales que deben ser interpretados en el marco de relaciones, prácticas y escenarios socioculturales concretos y en determinadas contradicciones históricas.

El Licenciado en Comunicación Social estará capacitado para:

- Conocer, planificar, articular, investigar y producir procesos comunicacionales;

- Reflexionar y comprender las dinámicas, las problemáticas y los procesos de comunicación;

- Elaborar prácticas comunicacionales en diferentes dimensiones a través de distintos espacios sociales, culturales, políticos, institucionales, tecnológicos e interdisciplinarios.

- Relacionar en sus conocimientos y en su acción las construcciones teóricas con las problemáticas de la práctica, a través de las mediaciones de las estructuras sociales, las lógicas de producción, las dinámicas culturales y las gramáticas discursivas.

El perfil de egresado que se propone en este Plan de Estudios se plantea desde una idea superadora de la división positivista entre teoría y práctica, entre el modelo cientificista y el profesionalizante. Se piensa en la posibilidad de un productor de comunicación como sujeto dotado de capacidad crítica, productiva, y creativa para desenvolverse frente a los problemas de comunicación existentes. Capacitado para actuar desde la comprensión de las realidades locales en continuo diálogo con lo transnacional y lo global, con habilidad para aplicar los conocimientos metodológicos, técnicos e instrumentales. Este perfil supone un sujeto que integre, en la generación de conocimientos, la actividad de produc- 
ción con al de investigación. En el plano socio-político, el perfil del Licenciado en Comunicación Social al que este Plan aspira es un egresado preparado para contribuir, desde su especificidad, a los procesos integrales de transformación social.

El Licenciado en Comunicación Social con Orientación en Periodismo estará capacitado -teórica y operativamente- para investigar, analizar, diagnosticar, diseñar, formular, ejecutar y evaluar productos periodísticos que tratan sobre acontecimientos que ocurren en los procesos sociales, económicos, políticos y culturales de la comunidad. La formación permitirá al egresado analizar -desde una perspectiva comunicacional y con herramientas inter y transdisciplinarias- aquellos procesos vinculados con todos los sectores a nivel internacional como nacional, provincial y municipal. La formación posibilitará al egresado diseñar y elaborar críticamente -desde una perspectiva comunicacional y con herramientas inter y transdisciplinarias- productos e instrumentos comunicacionales que utilicen los diferentes leguajes, para los diferentes formatos y/o soportes comunicacionales y por los diversos canales y/o medios de comunicación.

El Licenciado en Comunicación Social con Orientación en Planificación Comunicacional estará capacitado -teórica y operativamentepara investigar, analizar, diagnosticar, diseñar, formular, ejecutar y evaluar procesos, planes, programas y proyectos de comunicación social en los diferentes espacios y procesos sociales, económicos, políticos y culturales de la sociedad. La formación permitirá al egresado intervenir desde una perspectiva comunicacional y con herramientas inter y transdisciplinarias- en proceoso de comunicación vinculados con:

- Políticas públicas estatales, tanto a nivel nacional, provincial, regional y municipal, ejecutadas desde cualquier de los poderes que conforman el sistema de gobierno.

- Organizaciones e instituciones no gubernamentales o sin fines de lucro, cualquiera sea su nivel de actividad, ya sea tanto a nivel nacional, provincial, regional y municipal: de carácter micro, mediano y/o macro social;

- Organizaciones del Mercado o con fines de lucro, tanto las de producción de productos tangibles como intangibles y cualquiera sea tu 
dimensión operativa, pequeñas, medianas o grandes, cuya producción o servicio sea destinada al mercado local, regional, nacional o internacional;

- Otros espacios específicos de intervención o que se integren o confluyan transitoriamente en una política y/o actividad particular.

- El desarrollo de nuevas tecnologías de comunicación y en los nuevos procesos de producción sociales, económicos, políticos y culturales que dichos fenómenos generan.

\section{b) Del Profesorado en Comunicación Social}

En la Carrera de Profesorado en Comunicación Social se propone un horizonte de formación que equilibre las demandas y construcciones de nuevos campos de actividad profesional, como lo son los sistemas escolares y la educación no formal e informal, con las dimensiones que provoca el entrecruzamiento entre los saberes y los quehaceres del comunicador y el educador.

Se busca formar un profesional habilitado para:

- Organizar y coordinar procesos de enseñanza y aprendizaje de las diferentes problemáticas comunicacionales, en los distintos niveles y modalidades educativas;

- Analizar, producir, administrar y evaluar con criterio pedagógico-comunicacional distintos medios de enseñanza con diferentes grados de complejidad y tecnicidad.

- Analizar y producir estrategias de comunicación en instituciones educativas;

- Investigar problemáticas del campo relacional de la comunicación y la educación.

- Generar y coordinar la comunicación educativa en pequeños grupos y en instituciones educativas formales y no formales.

- Organizar y coordinar acciones educativas de alcance comunicacional masivo, institucional, empresarial, estatal y organizacional. 
El campo más específico de trabajo del Profesor en Comunicación Social son las instituciones escolares de los distintos niveles y modalidades, las instancias de educación no formal y las estrategias de educación informal. Su horizonte laboral se amplía a aquellos ámbitos de carácter educativo ligados al Estado, las organizaciones no gubernamentales, las empresas y las políticas integrales que se conocen bajo el nombre genérico de Mercado.

Hasta aquí los supuestos. Ahora se trata del análisis de lo sucedido.

El análisis focalizado en el proceso de desarrollo curricular derivado de la implementación del Plan de Estudios 98, se hizo bajo la idea de que tanto el Plan como el Documento de reforma, constituyen marcos reguladores y orientadores de los saberes y de las prácticas formativas, pero que los procesos institucionales y subjetivos que se pusieron en juego en su desarrollo, excedieron y reconfiguraron necesariamente al mismo.

\section{Sobre la flexibilidad y autoestructuración curricular}

- En este sentido estimamos, en cuanto a la estructura curricular y en particular a la flexibilidad, que la Reforma curricular del '98 se planteó, entre otras cuestiones, la necesidad de introducir mayores niveles de autoestructuración y flexibilidad en el diseño curricular. Es decir una mayor posibilidad de opcionalidad y movilidad, con la incorporación de más asignaturas cuatrimestrales y la disminución de correlatividades, entre otras estrategias.

- Esta cuestión de la mayor posibilidad de optatividades por parte de los alumnos generó diversos procesos, a saber:

- Una valoración positiva en torno de la posibilidad de elegir temáticas de mayor interés personal y/o grupal.

- La introducción de campos de conocimiento emergentes o de prácticas variadas con mayor flexibilidad y actualidad, especialmente en las Orientaciones.

- En el Ciclo Común, una fuerte opcionalidad, generó también, en cierto sentido, una problemática de tipo epistemológico en la formación, referido a una mayor dificultad para la visualización del modo en que se articulan las diferentes disciplinas en torno de los problemas u objetos 
propios del campo comunicacional, y por lo tanto, también de la singularidad de este campo.

- Esto presentó mayores dificultades en los alumnos ingresantes, por el desconocimiento de una lógica articulatoria entre disciplinas, de la complejidad de los saberes, etc.

- Generó asimismo dificultades para las propuestas docentes, debido a la disparidad de conocimientos previos en grupos de alumnos heterogéneos.

- La cuestión de la "autoestructuración" implica la necesidad de distinguir como cuestiones diferentes: la posibilidad de optar por temáticas diversas, por un lado; de la posibilidad de construir un recorrido formativo casi individual, por el otro. Estos aspectos requerirían de una formación a partir de una realidad educativa y social, en todos los demás niveles del sistema específico, cuyas posibilidades de transformación exceden la acción de nuestra voluntad de intervención.

- Fue importante realizar, entonces, una reflexión teórica, epistemológica y pedagógica respecto de ciertas consecuencias "no previstas", de un currículo flexible, en los procesos de formación, teniendo especialmente en cuenta los rasgos culturales y sociopolíticos del momento histórico actual. A la inversa, en una sociedad caracterizada por la fragmentación, por la ausencia o corrimiento de ciertos marcos de referencialidad, la pérdida de sentido de los proyectos colectivos por sobre los recorridos individuales, etc., un currículo con una mayor estructuración, podría tener la función de promover en los alumnos la adquisición de grandes marcos globales comprensivos desde los cuales situarse.

- En este sentido fue importante también discutir acerca de qué saberes o asignaturas cumplirían este rol, así como cuáles son los saberes básicos para la formación de un comunicador y cuáles serían complementarios, o cuáles los criterios para "recortar" esta complementariedad: saberes emergentes, saberes de otras disciplinas, saberes contextuales, etc. 
El Documento Curricular y Plan de Estudios 1998 presenta una estructuración en dos ciclos de formación: básica y orientada.

Esto significó:

- La profundización y mantenimiento de perfiles diferenciados en Orientaciones formativas

- Una mayor diferenciación de los objetos de formación específicos y de identidad de las orientaciones, cristalizada al establecer un menor número de materias comunes.

- La recreación del Profesorado en Comunicación Social y la posibilidad formal de inclusión de los egresados en el sistema educativo como campo laboral; así como la sistematización de espacios de intervención en proyectos educativos en comunicación o en general.

- Asimismo, el Ciclo Común debido a su perfil histórico, si bien incluyó una importante complejización del campo comunicacional, en general mantuvo un mayor desarrollo de saberes vinculados con el campo profesional del periodismo, fundamentalmente el gráfico.

- Las posibles líneas de transformación pueden atender, entonces, a:

La configuración de un Ciclo Común de carácter básico y general, que pueda fortalecer esta formación para las diferentes orientaciones.

La revisión de la articulación entre los perfiles profesionales (deseados y/o existentes) y los espacios de formación actuales.

La posibilidad de mayor vinculación de la formación ofrecida en las orientaciones con las prácticas profesionales, y especialmente los ámbitos reales de ejercicio profesional (a través de diferentes mecanismos como pasantías o proyectos)

La inclusión de alguna terminalidad que dé cuenta de saberes y prácticas que, dadas centralmente en el campo de las nuevas demandas sociales, normativas y políticas, completen una perspectiva más acabada sobre la realidad laboral y profesional. 
La cuatrimestralización de las asignaturas significó, tal como se lo proponía la Reforma, superar cierta rigidez escolarizada en un esquema curricular de pasaje de la totalidad de los alumnos de año en año. Propuso además una lógica de armado de espacios de formación más focalizados en torno de ciertos ejes o problemas centrales de un área o disciplina, dejando para las materias anuales espacios de trabajo más específicos en torno de prácticas o articulaciones con el medio que, en el desarrollo cotidiano, adolecieron de superposiciones, repeticiones y "rellenos" temporales que atentaron contra los propios supuestos articulatorios.

El Plan de Estudios 98 mantuvo una organización epistemológica de los saberes en tres áreas: Producción, Contextual y Comunicacional. Asimismo, esta diferenciación, se articuló también con la carga horaria y la opcionalidad / obligatoriedad y anualidad / cuatrimestralidad en las asignaturas, estableciendo diferencias también en la mayor presencia en la formación de algunas asignaturas o espacios formativos.

Si bien esta estructuración permitió reconocer espacios con un estatuto diferenciado y no una sumatoria de asignaturas, presenta algunos inconvenientes, entre los que puede señalarse:

- Una indiferenciación, en el área contextual, entre asignaturas que en efecto abordan aspectos relativos a los contextos o los marcos sociales, con aquellas que abordan saberes básicos de las ciencias sociales, y que fueron agrupadas (en tanto no integran las otras 2 categorías) como contextuales. En este sentido el conocimiento de la historia, de las ideas políticas, de las problemáticas sociales contemporáneas, etc. pueden pensarse como saberes que estudian los acontecimientos (dados en el contexto) más que los procesos. Sin embargo, otras vinculadas a la Sociología, Economía o Psicología, por ejemplo, delimitan categorías o conceptos que permiten dar cuenta del estudio básico de procesos que deben estudiarse de maneras más complejas desde el punto de vista transdisciplinar.

- Respecto del área de producción: las asignaturas incluidas en ella son aquellas que se articulan más fuertemente alrededor de una práctica profesional específica, o de una "competencia práctica" determinada. Especialmente en el ciclo común, se incluyen aquí las asignaturas vinculadas a los medios de comunicación o a producciones mediáticas; 
y se les asigna en su mayoría una duración anual. Sin embargo, sería importante, por un lado, no colocar a estas asignaturas como por fuera de un área comunicacional, pues se corre el peligro de pensar a la producción como una especie de saber "técnico" que no involucra definiciones o discusiones centrales del campo. Y por otro lado, que las asignaturas del campo comunicacional son "teoría", y no intervención, producción o reflexión sobre los contextos y las prácticas. En este sentido se podría generar una suerte de desarticulación teoría-práctica, y reforzar algunas de las dicotomías que se señalaban el inicio en el propio diagnóstico del Plan 1998. Así se refuerza la idea de que se produce o se "sumerge" al alumno en la práctica, en saberes vinculados al "periodismo", y que las otras asignaturas trabajan únicamente en el plano de la teoría. Ambas cuestiones deberían ser superadas. Esto no implica el desconocimiento de que, en efecto, hay espacios formativos cuyo objeto central son categorías teóricas, y otros cuyo objeto lo configura una práctica o competencia práctica específica. Sin embargo, la delimitación de un área de "prácticas" o de "producción" debe incluir la dimensión práctica de diferentes asignaturas y no sólo las ligadas al periodismo o los medios.

\section{Espacios interdisciplinarios}

Uno de los ejes de transformación se conformó alrededor de la necesidad de introducir espacios interdisciplinarios de formación, que rompieran en parte con la lógica de un currículo estructurado en disciplinas compartimentadas.

Esta reformulación curricular se expresó en el desarrollo e implementación de los Seminarios Interdisciplinarios, que a partir del año 2002, fueron incorporados también al Ciclo Común. Puede decirse que, tanto por el desarrollo de propuestas docentes novedosas, como por la importante cantidad de alumnos que eligen esta modalidad de cursada, en líneas generales estos espacios resultaron movilizadores de la discusión y el debate en torno de diversos problemas del campo comunicacional, no necesariamente incluidos en la formación básica. Sin embargo deben mejorarse cuestiones relativas a su implementación, y a la planificación más sistemática de su oferta, a la articulación con las asignaturas obligatorias, etc. 


\section{Producción de conocimientos e investigación en el grado}

En cuanto a la cuestión de la Tesis, su inclusión e implementación ha sido objeto de mejoramiento y análisis en diversos espacios institucionales, con la participación de los propios tesistas, de modo que las conclusiones y revisiones que se han venido planteando desde la vigencia del Plan deben ser recuperadas del trabajo generado en estos ámbitos.

Algunas de estas reflexiones apuntan a encontrar mecanismos en el propio desarrollo curricular de:

- Articulación entre asignaturas vinculadas a la producción de conocimientos con las restantes del Plan.

- Mayor orientación a los estudiantes desde el inicio de la Orientación en la elaboración de la Tesis, de manera que transite las materias pensando en su objeto-problema, y no lo realice exclusivamente a posteriori de la finalización de la carrera.

- Posibilidad de ubicar los espacios destinados a la formación específica en un eje que, dentro del Ciclo Superior, acompañe el proceso de elaboración de la Tesis.

- Integrar el concepto de Prácticas Profesionales (o preprofesionales) a las opciones de terminalidad de la Licenciatura.

El Plan 98 promovió la existencia de una variedad de modalidades de cursada: seminarios, seminarios interdisciplinarios, talleres y asignaturas teórico prácticas.

Resulta interesante la posibilidad de sostener las mismas, en virtud de la intencionalidad de formar a los alumnos en torno del reconocimiento de saberes de diferente naturaleza que pueden ser tratados de manera distinta en cada uno de estos espacios.

Masificación de los sistemas de promoción sin examen final

Se debe revisar la conveniencia de extender este sistema a la totalidad de las asignaturas, o reservarla a aquellas cuyos aprendizajes van desarrollándose progresivamente, sin necesidad de una integración final específica. 
Algunas consideraciones generales sobre los aspectos centrales propuestos para la reforma

- Las observaciones críticas apuntadas, en los diferentes consensos arribados dentro del proceso de las discusiones, no eran solucionables íntegramente al interior de las actuales estructuras y condiciones curriculares.

- La estructura curricular de la Facultad no se recorta al Plan de Estudios de las carreras de grado (Licenciatura y Profesorado) sino que está constituida por todas las instancias formativas formales sobre las cuales se practican y activan procesos de enseñanza-aprendizaje.

- El momento de discusión y creación del Plan de Estudios 1998 estuvo definido, centralmente, por una postulación identitaria constitutiva de los saberes y prácticas de la comunicación, como así también de las condiciones político-institucionales de nuestras carreras y de la propia Facultad de Periodismo y Comunicación Social.

- Se constituye la necesidad de reinstalar un proceso de diálogo audaz y creativo con el conjunto de las ciencias sociales, a partir del propio posicionamiento en un nivel de igualdad y densidad epistemológica.

- Se advierte la imprescindibilidad de un lazo intenso de los propios supuestos disciplinares con las realidades normativas y materiales concretas de los diferentes niveles del sistema educativo y las condiciones de desarrollo profesional.

- A partir del reconocimiento de un contexto histórico-social muy diferente del momento en que se debatió el Plan 98, pero también de la constitución de un perfil de alumno con un nivel de formación e intereses, también, muy diferente, para los que resultan inadecuados las propuestas curriculares en vigencia, se debe establecer un recorrido inicial básico que contenga e incluya al conjunto de necesidades que representan los alumnos. Y que esta formación básica, disponga recorridos claros y estructurados en una progresividad suficiente sobre el sentido y valor institucional que se le da a los estudios superiores universitarios en Comunicación. 
- Desde el reconocimiento institucional que se le ha dado a prácticas y saberes de la especificidad, dando cuenta de una complejidad que no se suponía hace poco tiempo atrás, se debe establecer un ingreso pleno de estos desarrollos a la estructura curricular, dejando abiertos espacios para la experimentación, prueba y consolidación de futuras adquisiciones del campo.

- Precisar los saberes o asignaturas básicos para la formación y cuáles pueden ser opcionales o deben reformularse para ser incluidos en niveles más avanzados.

- Arribar a una lógica de diferenciación de orientaciones más acabada, a partir de contenidos básicos, centrales y comunes para un Licenciado y/o Profesor en Comunicación Social. Y no "adelantar", tempranamente en el ciclo común (incluyendo materias o espacios relacionados con ellas en este ciclo), ya que de lo contrario se tendería a "especializarlo".

- Reconocer, dentro de aquella complejidad anunciada más arriba, los núcleos de mayor desarrollo y densidad conceptual en nuestra institución para su profundización gnoseológica en nuevos estudios orientados.

- Ampliar los niveles de estructuración curricular de modo de orientar un recorrido de formación, sin tocar los límites de la rigidez o de la excesiva escolaridad.

- Rever la lógica epistemológica de las áreas de conocimiento actuales, manteniendo un equilibrio entre la formación teórica y la práctica; entre diferentes objetos o problemas del campo y entre prácticas profesionales diversas.

- Revisar en función de los dos puntos anteriores, la anualidad / cuatrimestralidad de las asignaturas, al revisar los criterios subyacentes en el Plan vigente.

- Destacar la consistencia de las características formales de la estructuración en ciclos y duración, así como de las cantidades de espacios curriculares a recorrer y cumplir.

- Considerar los espacios formativos con alternancia de presencialidad y valorizar la potencialidad de la virtualidad.

- Seminarizar unidades de los programas. 
- Estimular las adecuaciones de estudios equivalentes con otros espacios formativos.

- Acreditar tramos educativos con el fin de reconocer todas las prácticas y saberes desarrollados y obtenidos, desde un punto de vista del derecho de cada sujeto.

El plan que desarrolla estos perfiles se implementó en 1998 y continúa vigente, con numerosas modificaciones. Actualmente ya ha sido revisado, pero a los efectos de esta tesis, siguen siendo operativas las tensiones en tanto hipótesis curriculares a implementar:

Que la estructura del Plan era altamente escolarizada porque prescribía más que permitía la autoestructuración, porque tenía un diseño cerrado que impedía modificaciones u opciones parciales, porque impedía el reconocimiento de nuevos objetos de estudio, de objetos transversales y de nuevos lenguajes y prácticas de apropiación.

Que no reconocía temáticas imprescindibles como las Nuevas Tecnologías de la Información, y que el alto nivel de estructuración impedía prácticas investigativas de nuevo desarrollo

Que, en lo epistemológico, el campo de la comunicación había pluralizado sus formas de constitución y expansión, a la vez que se habían complejizado los perfiles académicos y profesionales, mientras que el Plan no lo contemplaba.

Que la base socio-profesional estaba construida alrededor de la clara imagen social del "periodista", mientras que las cuestiones de la "comunicación" aún no aparecían. Lo cual hacía insuficiente el planteo formativo ante los acelerados cambios que se producen en el mundo de la comunicación y el carácter crecientemente articulador de las prácticas comunicativas.

Pero, sobre todo, se observaba que la plena transformación institucional que aumentaba la complejidad (más investigación y aparición de diversos Centros, estudios de posgrado, numerosos trabajos de extensión y de producción comunicacional en relación con el entorno social, cultural y profesional) no estaba ni siquiera enunciada o problematizada para su incorporación curricular formativa. 
De acuerdo a este análisis, se plantearon objetos de transformación: Frente a la rigidez escolarizante, se propuso un camino de flexibilización, interdisciplina y opciones diversificadas de formación; ante la linealidad y su tendencia a la reproducción de conocimientos, se postuló la complejidad y la generación de conocimientos originales en el campo comunicacional; respecto de la desarticulación teoría-práctica, se propuso instaurar espacios de articulación, procesos interdisciplinarios y acciones de transversalidad. Y, de manera fundamental, los alcances de la reforma comprometieron el proyecto institucional de formación de comunicadores, las diversas actividades y alternativas pedagógicas y los contenidos que las sostenían, el hacer docente y la totalidad de las prácticas institucionales de formación.

La complejidad de la situación intra y extramuros obligaba a desentrañar los problemas desde los nuevos campos localizados en las Ciencias Sociales, otorgando a las prácticas y estudios comunicacionales una dimensión transdisciplinaria.

El posicionamiento fue aprovechar la necesidad de transformación curricular para dar cuenta de un proceso de desarrollo institucional que permitiera superar la crisis de posicionalidad que a nivel de la producción cultural y por ende del currículo universitario limita la perspectiva de aquellas tendencias y movimientos sociales que intentan resolver cuestiones de desigualdad y redistribución social. Es decir, una perspectiva crítica del currículum que lo constituya en un referencial común operativo con direccionalidad político-valorativa amplia (no universal normativa, sí de inclusión de las diversidades), un curriculum en desarrollo que supere la interpelación de la obsolescencia ante las demandas del mundo actual. Por tanto, el cambio deseado se orientó en pos de la construcción siempre inacabada de una organización-sujeto que construyese nuestro objeto al mismo tiempo que propendíamos al aprendizaje organizativo.

La proposición fue a pensar simultáneamente el curriculum y nuestra Facultad como concreciones en un proceso histórico-social determinado y complejo, bajo el cual debíamos concretar una contribución a la producción social y personal, que trascendiera las epistemes existentes e interpretase las diferentes culturas y lenguajes, reconociendo las múltiples diferencias y representarlas produciendo su articulación crítica. 


\section{Consideraciones finales}

Mientras enseño continúo buscando, indagando. Enseño porque busco, porque indagué, porque indago y me indago. Investigo para comprobar, comprobando intervengo, interviniendo educo y me educo. Investigo para conocer lo que aún no conozco y comunicar o anunciar la novedad"

Paulo Freire Pedagogía de la Autonomía"

A lo largo de este recorrido describimos lo más densamente posible las características de sujetos, objetos y procesos que intervienen-intervenimos en la institucionalización de este caso en situación de aquel paradigma hipotético de la síntesis inicial.

Por fin, ahora, concluimos con lo que consideramos es el sentido de unidad de tanto recorrido histórico, tanto contexto institucional y epocal, tanta palabra clave, tanta caracterización curricularista, tanto contenido disciplinante.

Esta tesis comenzó a ser embrión en el mismo momento de nuestra inserción institucional, a finales del siglo pasado. Las problemáticas de lo curricular, el conocimiento de la comunicación, la comunicación del conocimiento, empezaron a preocuparnos contemporáneamente al asesinato del fotógrafo José Luis Cabezas, mientras se producía la primera clonación animal (oveja Dolly), o en Atlanta (EEUU) se creaba CNN en Español, o en Perú el gobierno de Fujimori retomaba el control de la embajada japonesa y ejecutaban a todos los guerrilleros del Movimiento Túpac Amaru, o mientras Gran Bretaña traspasaba el control de Hong Kong a la República Popular China después de 155 años de colonización del territorio, o en Bolivia se descubrían los restos del Che Guevara 30 años después de su asesinato, mientras en París moría en un accidente automovilístico la Princesa Diana de Gales y en India la Madre Teresa de Calcuta. Eran aún los años donde Soda Stereo realizaba su último con- 
cierto en el Estadio Monumental de Buenos Aires y Patricio Rey y sus Redonditos de Ricota lanzaban Último bondi a Finisterre, o J. K. Rowling publicaba Harry Potter y la piedra filosofal, Andrés Calamaro presentaba Alta Suciedad, Madonna lanzaba Evita. Titanic recibía 11 Óscars, Microsoft lanzaba a la venta Windows 98 y se fundaba la empresa Google. En los medios nacionales se consolidaban los grupos Clarín, Multimedios América y CEl Citicorp, asociados con Editorial Atlántida, TCl y TyC , y se montaba la Carpa Blanca docente frente al Congreso pidiendo, entre otros reclamos, la sanción de una ley de financiamiento educativo mientras que el gobierno de Carlos Menem firmaba la concesión de los 33 aeropuertos nacionales por un período de 30 años al consorcio Aeropuertos Argentina 2000.

Es decir no nos habían sucedido la Alianza, De la Rúa y Chacho Alvarez, el Euro, la masacre de Columbine, la serie Bob Esponja. Michael Jordan todavía jugaba en la NBA, EEUU todavía tenía en su poder el Canal de Panamá, la OTAN no bombardeaba Yugoslavia, no se había caído el avión de LAPA en Aeroparque, Endemol Holanda no había creado el reality Gran Hermano, la Nintendo 64 todavía no corría tras de Super Smash Bros, y Bianchi no había sacado campeón a Boca. Los Red Hot Chili Peppers no habían cantado Californication, George Lucas no había estrenado Star Wars Episodio I, ni los Hermanos Wachowski habían pergeñado The Matrix, tampoco habíamos visto aún Toy Story 2 y Joaquín Sabina no había cantado 19 días y 500 noches ni Roxette Have a Nice Day. Augusto Pinochet no sólo vivía sino que era nombrado senador vitalicio con honores y todavía vivía René Favaloro. Aún Michael Schumacher no había salido campeón con Ferrari y Saddam Husein repetía en el Consejo de Seguridad de NU que no tenía armas de destrucción masiva mientras que lo escuchaba el aún candidato George W. Bush al mismo tiempo que no conocíamos al mal de las vacas locas. Todavía no se habían inventado las estrategias de simulación social de The Sims y Sony no había puesto en circulación la Play Station 2. Andrés Calamaro no había cantado El Salmón ni Madonna Like a Virgin y no habíamos visto Amores Perros ni El señor de los Anillos ni Shrek. Tiger Woods aún era un caddy y no se sabía qué era Wikipedia. En Afganistán los talibán empezaban a tallar y palabras como iPod o Microsoft Windows XP no se conocían. Lula aún no había llegado a la presidencia de Brasil y es- 
taban vivos Stanley Kubrick, Adolfo Bioy Casares, Cris Miró, Rodrigo, Vittorio Gassman, Iván Illich, Tita Merello y Pierre Bourdieu... todo esto, antes de cambiar de milenio, hace 14 años atrás.

Luego vinieron todos los 2000 y nuestra Facultad también hizo lo suyo en materia de aportar complejidad a los pensamientos y acciones. Hoy tenemos $3908^{142}$ alumnos regulares en la Licenciatura en Comunicación Social (con aquellas dos orientaciones de Periodismo y de Planificación Comunicacional), en el Profesorado en Comunicación y en las Tecnicaturas en Periodismo Deportivo y en Comunicación Popular. 1.048 143 son alumnos en el Posgrado (Doctorado en Comunicación, Maestrías en Planificación y Gestión de Procesos Comunicacionales, en Periodismo y Medios de Comunicación, y en Comunicación y Derechos Humanos, Especializaciones en Comunicación Radiofónica, en Comunicación y Medio Ambiente, en Ámbitos, Medios y Prácticas Educativo-Comunicacionales, en Comunicación y Salud, en Edición y en Periodismo Cultural). Hemos desarrollado los estudios de grado en 14 extensiones áulicas (Formosa, Monte Caseros Corrientes, ISER CABA, Moreno, Chivilcoy, Henderson, Bolívar, Punta Alta, Miramar, La Costa, Carmen de Patagones, Las Flores, Ushuaia, Río Grande). La conformación actual de la propuesta curricular de grado alcanza alrededor de 80 asignaturas entre cátedras, seminarios y talleres. Están en desarrollo 7 Cátedras Libres (Derechos Humanos, Juan D. Perón, Mercosur, Rodolfo Walsh, Leandro N. Alem, Soberanía Alimentaria y Malvinas, Comunicación y Nación). Funcionan 3 Centros de Extensión (en Comunicación y Género, La comunicación y los Adultos Mayores, de Comunicación del Ambiente), 4 Centros de Investigación (CICEOP, CILE, CPS y CIEPyC) y el Instituto de Investigaciones en Comunicación (IICom), 4 Observatorios (Comunicación, Géneros y Diversidad con perspectiva en DDHH, Jóvenes, Medios y Comunicación, Comunicación y Salud, y Medios con perspectiva de Género) donde desarrollan tareas más de 1000 investigadores y extensionistas. Sigue publicándose Oficios Terrestres, Question/Cuestión lleva más 10 años de existencia, se publicaron 80 números de Tram(p)as de la Comunica- 
ción, y Ediciones de Periodismo y Comunicación lleva más de 70 títulos editados. También trabajan la Agencia Periodística de Buenos Aires, numerosos proyectos de Voluntariado Social, Programas de Educación en Cárceles, en Asociaciones Civiles... en una mención sumaria que día a día complementa otra realización.

Todo en un contexto específico que incluye la explosión en la circulación informativa planetaria que supone Internet, la vertiginosidad del crecimiento de las redes sociales virtuales, de las concentraciones en la propiedad de los medios de comunicación, de la proliferación de nuevos medios y soportes tecnológicos, de las opciones formativas tomadas por cada vez más estudiantes de todas las edades, de normativas concentradoras de poder y de normativas ampliatorias de derechos sociales e individuales.

Vaya como ejemplo la inexistencia de blogs, facebooks, googles, HDs, wikis y leyes de servicios de comunicación audiovisual no sólo como hechos concretos, históricos, sino también como meras palabras en aquel tiempo en que la problemática de esta tesis comenzaba a constituirnos.

Es decir, estamos en otro mundo, en otro tiempo, que están en los mismos que nosotros estamos construyendo, protagonizando e impulsando. Por lo tanto, para ser precisos, las hipótesis de interpretación integrales de lo institucional siempre son imperiosamentes necesarias. Aquellas que den cuenta de las readecuaciones y reingenierías, así como de las nuevas necesidades disciplinarias, sociales, históricas.

Porque ya no era suficiente pensar en perfiles que hablaran de producir hechos y procesos socioculturales interpretables en el marco de relaciones, prácticas y escenarios socioculturales concretos y en determinadas condiciones históricas. Sino que era necesario la existencia de profesionales críticos, comprometidos socialmente, que contaran con las herramientas para trabajar en un contexto, reconocerlo (leerlo), interpretarlo y reflexionar en pos del beneficio común que incluya a toda la comunidad con la que interactúa. Que comprendieran la Comunicación como proceso integral y de múltiples dimensiones y que se planteen la generación de procesos comunicacionales a través de los cuales se visibilicen ideas, necesidades y problemáticas sociales en los diversos ámbitos o medios de participación ciudadana, valorando los procesos populares 
y con capacidad de incidencia en los procesos de transformación social. Profesionales que conozcan la diversidad de medios y los nuevos modos de producción, circulación y re-apropiación de los bienes simbólicos. Que conozcan y defiendan la Ley 26.522 de Servicios de Comunicación Audiovisual para tener en cuenta los escenarios comunicacionales, culturales y políticos que se proyectan. Formados en los procesos de gestión de medios y con capacidad de reconocer identidades culturales en un contexto social y político que debe poder explicar, para generar diversas formas de manifestaciones comunicacionales que sean el motor de actividades para el desarrollo del ámbito cultural, social y educativo. Profesionales que no solo deben saber expresarse a través de la escritura, sino también deben tener una buena dicción y expresión de sus conceptos intelectuales. Que reconozcan los distintos formatos de producción de contenidos producto de los cambios tecnológicos. Que sean productores de contenidos, materiales y productos de comunicación en los medios del Estado y en los privados. Que se reconozcan como productores de conocimiento y deseen ponerlo en circulación, multiplicándolo.

Porque, de fondo, se asiste a un profundo replanteo de la función social de la Universidad, de la formación para la Comunicación del Conocimiento, del Conocimiento de la Comunicación, frente a las importantes transformaciones de la época, y de crecientes necesidades de diverso tipo (sociales, de desarrollo tecnológico y económico, científicas, etc.) especialmente derivadas de las políticas económicas mundiales y los cambios en el rol tradicional del Estado. Debates que se resuelven de diversa manera según se ponga el acento en articular acciones y funciones con el Mercado, con el Estado, con las comunidades académicas y o con los nuevos movimientos sociales emergentes en el contexto de las transformaciones culturales actuales y en oposición a políticas liberales o neoliberales.

Sin embargo, estos cambios no son producto de consensos sino de una profunda crisis que nos atraviesa como sociedades contemporáneas. En los últimos veinticinco años asistimos alternativamente al derrumbe del muro de Berlín, que marcó el término de la experiencia socialista, y a una crisis del capitalismo globalizado cuyo final es incier- 
to. La crisis económica-financiera que afecta al mundo globalizado es una de las más importantes de los últimos cien años y es, a su vez, una crisis de la sociedad que ha sostenido un modelo económico que llevó a la desigualdad, a la pobreza y a la explotación de millones de seres humanos, al mismo tiempo que benefició muchísimo a muy pocos. Hoy hay un debate sobre nuevos paradigmas políticos, económicos, sociales y culturales, que debe impactar en las políticas estatales. Hasta dónde se involucren los Estados en su rol de contralores del Mercado y en la implementación de políticas públicas, es la medida de la posibilidad de salir de la crisis, o sólo de aggiornar con un superfluo maquillaje la situación. En estas circunstancias es imposible pensar que los espacios institucionales no estén atravesados por ella. Las que nos conforman como formadores de "comunicadores" no eran ni son la excepción a la regla.

Estamos en una institución que protagoniza la generación de nuevas ideas, que suma hacia la construcción de una sociedad distinta, en pos de estrategias para el desarrollo nacional. Pero también debe ser un ámbito de oportunidades para el conjunto, para una mayoría mucho más amplia de la que hoy asiste. Porque en los recursos humanos que formamos también estarán las posibilidades de repensar modelos y soluciones.

En particular, somos reflejo de los resabios del pasado y de las luces del futuro de cada tiempo, y la forma de la política es la traducción de los conflictos, las necesidades y los obstáculos que tiene la sociedad en materia de distribución de la cultura entre y dentro de las distintas generaciones, clases sociales, sectores étnicos, culturales, entre otras cuestiones.

En nuestra tradición latinoamericana hay que recordar que la orientación de la formación de profesiones se adecuó a las vicisitudes de las nuevas repúblicas, que quedaron ubicadas en la periferia de la sociedad industrial avanzada, corrida de la herencia de Salamanca y Bolonia como modelos hegemónicos y fundantes. El Movimiento Reformista de 1918 puso de manifiesto que las universidades latinoamericanas estaban descolocadas respecto de sus pares europeas y norteamericanas para las cuales sus reclamos eran extraños. Detrás de nuestras universidades ha crecido siempre la utopía de una modernidad propia. 
Si ya en 1918 la juventud universitaria latinoamericana emprendió un camino distinto, ¿cómo no hacerlo casi un siglo después, en una situación donde se han tensionado fuertemente las articulaciones internacionales que subordinaban a nuestros países, sometidos mediante deudas externas impagables, balanzas deficitarias y la lógica de la economía financiera rigiendo sobre nuestro aparato productivo y nuestra vida social?

Las sociedades latinoamericanas han acumulado dolorosamente experiencias que les permiten definir con claridad qué es una crisis; todos nuestros pueblos han desarrollado saberes de sobrevivencia, tecnologías de subsistencia y, en el presente, no solamente hemos ensayado modelos de gobierno orientados hacia la independencia económica, la soberanía política, la justicia social y la democracia, sino que muchos países lo hacemos con signo propio, como políticas de Estado.

La opción por la extensión de la cultura y la escolarización en América Latina, tuvo siempre como motor las políticas que representaron a las grandes masas y requirió de la educación para poder sostener políticas de desarrollo. Esta opción asume políticas educativas universales, inclusivas, que otorgan protagonismo a los pueblos, que se vinculan con la producción y el trabajo antes que con el Mercado, que buscan la producción de saberes para una distribución justa de la riqueza material y simbólica.

La concepción de autonomía universitaria de los reformistas de 1918 proyectó un Estado complejo, superador del Estado instrumento y constituido por organismos que cumplen distintas funciones y sostienen distintos tipos de articulaciones con el conjunto. La autonomía universitaria pensada de ese modo no conduce a la idea de extraterritorialidad, no estimula el desprendimiento de la institución productora de saberes respecto del Estado, sino que se propone como un reaseguro de la posibilidad de producción de conocimientos para la sociedad por parte del Estado, más allá de las vicisitudes que lo atraviesen. La intención es generar las condiciones para aportar a la autonomía del Estado nacional y el desarrollo de la sociedad.

La autonomía, la libertad de cátedra y el cogobierno han estado presentes en los dos grandes proyectos universitarios en los que encuentra 
identidad la política de inclusión y desarrollo. Son ellos la Universidad Latinoamericana que concibió el antropólogo brasileño Darcy Ribeiro y los proyectos universitarios que en 1974 intentaron reaccionar frente a la universidad liberal cientificista, impulsada a partir del golpe del 55 que, si bien significó una modernización en el plano de la producción científica y la vinculación internacional con la producción científica fue insuficiente en cuanto a su participación política y su vinculación con el proyecto de desarrollo.

\section{Los elementos confluyentes eran, y son:}

- Visualizar como horizonte de la docencia, la investigación y la extensión el aporte a la independencia científica, económica, creativa y tecnológica del país; afirmar la conciencia nacional solidaria y comprometida con los problemas nacionales y latinoamericanos, la preparación de técnicos, profesionales e investigadores adecuados a la resolución de los problemas del país; orientar hacia la provisión de respuestas científicas y productivas a los sectores más necesitados; todo en el marco del estudio de problemas de la comunidad.

- Posibilitar la libre expresión de las ideas, de investigación y de creación, respetando los principios de la Constitución Nacional; proporcionar una formación en la cultura universal al mismo tiempo que el conocimiento de la realidad político-social argentina y latinoamericana; donde la educación política dialoga productivamente con la formación científica y artística.

- El planeamiento ordenador del conjunto de la formación superior y su vinculación con los programas de desarrollo para la integración de las políticas nacionales con las regionales.

- Comunicación del Conocimiento, el Conocimiento de la Comunicación problematizó también el concepto de conocimiento en el contexto de convergencias tecnológicas, de nuevos modos de producir sentidos ${ }^{144}$. 
- Que la sociedad del conocimiento El saber científico, en la sociedad del conocimiento, asume que hay otras formas de saber145, otro tipo de racionalidad. Si aprovechamos esta crisis y nos quedamos con los saberes centrales los vamos a seguir utilizando para excluir, para dominar. Lo que está en juego es la formación de ciudadanos. Educar para convivir con lo distinto, el conflicto, lo radicalmente otro que cuestiona lo que yo creo, pienso, y no con palabras, con una manera de vestirse, de contar, de caminar, mi manera de ser.

- Atravesamos una crisis en los modos de comunicar el conocimiento, definiendo crisis como un momento en el que algo clave, decisivo, está muriendo y lo nuevo no acaba de nacer, no tiene forma definitiva todavía.

Pensar así este proceso en estudio es pensarlo en función de un proyecto de desarrollo humano y social sostenible, anclado en un desarrollo nacional. Debemos recuperar a la educación y a la comunicación como instancias articuladoras sociales, retomando continuidades pero, sobre todo, realizando rupturas que nos permitan generar una nueva concepción integral, que contemple la diversificación, la flexibilización y la descentralización sin perder de vista la unidad y la cohesión nacional. Esto implica pensarlas como prioridades nacionales, no como servicios, y sí como ejes que atraviesan todas las prácticas, todas las políticas y todos los sectores sociales.

El planteo de esta tesis surgió de una necesidad complementaria a nuestra cotidianeidad del trabajo docente, investigador, extensionista, profesional: la propia comprensión del estado de situación que nos compone, rodea, construye, permite, autoriza, provoca, posibilita, aporta,

arriba hacia abajo: vertical. Esta visión binaria del mundo y determinista del mundo: lo bueno, lo malo, lo alto, lo bajo, el macho, la hembra...Toda esa visión dicotómica ha sido siempre la responsable de la exclusión, de la dominación. Uno de los dos domina al otro: adulto-niño, el adulto tiene derecho a dominar al niño; hombre-mujer, el hombre tiene derecho a dominar a la mujer; blanco-negro, el blando tiene derecho a dominar al negro... O sea, en una sociedad de clase toda diferencia se convierte en ocasión de dominio, porque no podemos pensar sino en términos dicotómicos. En oposición, decimos que Internet es emancipador en la medida en que lo tomamos como un juego y el juego es colectivo, aunque también tiene muchas dimensiones amenazadoras. La red nos dice que es mucho más efectivo un montón de pequeños grupos bien conectados que un grupo grandísimo porque buscamos fortalecer la sociedad de los saberes compartidos contra el modelo del saber científico compartmentado: Cuánto más especializado: más valioso, más incapaz de conectarse con otros tipos de saberes que hay en la sociedad, sin los cuales no son manejables. Lo que está en juego no es sólo la trasformación del saber, convertido en conocimiento científico, si no de los diversos saberes, culturas que habitan al interior de nuestras propias ciudades. 
transforma. La oportunidad de esta tesis del Doctorado en Comunicación le ha dado origen y sentido a partir de presentar, definir y poner en tensión esta experiencia, describiendo densamente el devenir que nos resulta, caracterizando los contextos operativos, conceptualizando y aportando una crítica propositiva, política. Esta tesis mapea la experiencia histórica del proceso de la Facultad de Periodismo y Comunicación Social de la Universidad Nacional de La Plata como caso paradigmático del campo, como superación de las tradiciones sólo institucionalizantes, meramente desescolizadoras, profesionalizantes, cientificistas o empiristas. Y lo hemos hecho bajo la consigna compleja de hacerlo en tiempo y espacio, historizando y conceptualizando los sujetos de derecho y necesidades, las estructuras curriculares, los contextos, las instituciones, sus organizaciones y las prácticas hegemónicas.

Entendemos, entonces, que aporta originalidad y utilidad ya que analiza -desde una perspectiva crítica que propone una construcción posible y deseable- uno de los problemas más relevantes de la actualidad política en nuestros territorios: la. También aporta una vinculación original entre los procesos tradicionales del desarrollo académico y los estudios institucionales, constituyendo una línea de discusión, intervención e investigación en el "campo", así como es pertinente porque recorre el espacio de la línea Comunicación, Sociedad y Cultura que el Doctorado propone como una de sus vertientes principales. 


\section{Bibliografía}

AA.VV. Bases para la discusión de una política de ciencia y tecnología. Secretaría de Ciencia y Tecnología. Ministerio de Cultura y Educación. República Argentina. 1996

AAVV Políticas Científicas De Comunicación, Ediciones de Periodismo y Comunicación, La Plata, (1998),

AGUERRONDO Inés, "La calidad de la educación: Ejes para su definición y evaluación”, La Educación, XXXVII. 116 (1993): 563.

AGUERRONDO, Inés - Brunner, José J. - Burbules, Nicholas C. - Duro, Elena - Hepp, Pedro - Kelly, Valeria - Lugo, María Teresa - Magadán, Cecilia - Martín, Elena - Morrissey, Jerome Tedesco, Juan Carlos. "Las TIC: del aula a la agenda política”. IIPE - UNESCO Buenos Aires y UNICEF. Argentina, 2008.

ALBARRACIN, Santiago vicepresidente de Aruna (Asociación de Radios de Universidades Nacionales). en http://informacionpresupuestaria.siu.edu.ar/DocumentosSPU/Cuadernillo-decada-ganada.pdf

ARONSON Jonathan D F y. COWHEY Peterand. "Transforming Global Information and Communication Markets" The Political Economy of Innovation The MIT Press Cambridge, Massachusetts London, England 2009

ATTALI, Jacques. Diccionario del siglo XXI. Barcelona. Paidós. 2007

BACHELARD, Gastón La formación del espíritu científico, Buenos Aires, Argos. (1948)

BAKARDJIEVA, M. The Internet and subactivism. Cultivating young citizenship in everyday life. En T. Olsson \& P. Dahlgren (Eds.), Young people, icts and democracy. Theories, policies, and websites (pp. 129-146). Gotemburgo, Suecia: University of Gothenburg-Nordicom. (2010).

BANAJI, S. The trouble with civic: A snapshot of young people's civic and political engagements in twenty-first-century democracies. Journal of Youth Studies, 11 (5), 543-560. (2008).

BARABÁSI, Albert-László "Network Theory - The Emergence of the Creative Enterprise", Scientific Barcelona, Paidós. (2005)

BATESON, G., Jackson, D. D., Haley, J. \& Weakland, J., (1956,) Toward a theory of schizophrenia.Bourdieu, Pierre, - La lógica de los campos: habitus y capital.

BAUMAN, Zygmunt Modernidad líquida, Buenos Aires, Fondo de Cultura Económica. (2002) BECERRA, Martín Sociedad de la Información: proyecto, convergencia, divergencia, Buenos Aires, Norma. (2003) 
BECK, U. The reinvention of politics: Rethinking modernity in the global social order. Cambridge: Poltical press. (1997).

BENJAMÍN, Walter. Cuadros de un pensamiento. Buenos Aires. Imago Mundi. 1992.

BENKLER, Yochai The Wealth of Networks. How Social Production Transforms Markets and Freedom, New 2006)

BLEJMAR, Bernardo. Gestionar es hacer que las cosas sucedan, Competencias, actitudes y dispositivos para diseñar instituciones educativas - Ed. Novedades Educativas, 2005

Blood, Rebecca (2005) Universo del Weblog. Consejos prácticos para crear y mantener su blog. Barcelona.

BOAVENTURA DE SOUSA SANTOS “Una epistemología del Sur: la reinvención del conocimiento y la emancipación social", (Ed. Siglo XXI y CLACSO, México, (2009)

BOURDIEU, Pierre "Distinction: A Social Critique on the Judgement" 01 Taste, Cambridge, Harvard University Press, 1984

BOURDIEU, Pierre y J.C. Passeron. Los herederos. Los estudiantes y la cultura. Buenos Aires. Siglo XXI. 2004

BOURDIEU, Pierre y otros El oficio del sociólogo, Siglo Veintiuno Editores, México (1990).

BOURDIEU, Pierre y WACQUANT Loïc J. D. “Respuestas. Por una antropología reflexiva”. México: Grijalbo. (1995)

BOURDIEU, Pierre.; Passeron, J.C. “La reproducción; elementos para una teoría del sistema de enseñanza", Barcelona, Laia. (1977),

BOURDIEU, Pierre; "Capital cultural, escuela y espacio social”, México, Siglo XXI, cap. 9. (1997)

BRUNER, Jerome (1997) “La Educación, puerta de la cultura”, Madrid, Aprendizaje - Visor.

BRUNNER José Joaquín, Globalización Cultural y Posmodernidad; Fondo de Cultura Económica, Santiago de Chile (1998)

BRUNNER, JOSE JOAQUIN Gobierno universitario: Elementos históricos, mitos distorsionadores y experiencia internacional. En: Cox, Cristian (ed.), Formas de gobierno en la educación superior: nuevas perspectivas, FLACSO, Santiago de Chile. (1990)

BRUNNER, José.Joaquín.),'América Latina al Encuentro del Siglo XXI”; documento presentado al Seminario América Latina y el Caribe frente al Nuevo Milenio, organizado por el BID y la UNESCO, París (1999)

BUCKINGHAM, David Educación en medios. Alfabetización, aprendizaje y cultura contemporánea, Amorrortu. (2005) Buenos Aires

BURBULES, Nicholas y Thomas Callister "Educación: riesgos y promesas de las nuevas tecnologías de la Información" Buenos Aires, Granica, 2006.

BUSH, Vannevar (1945) "Cómo podríamos pensar". Disponible en: http://biblioweb.sindominio.net/

CALDERÓN, F. y Santos, M.“Veinte tesis sociopolíticas y un corolario en Estado, nuevo orden económico y democracia en América Latina", Caracas, ALAS-Nueva Sociedad. (1992), 
CAMILLONi, Alicia (comp.) Los obstáculos epistemológicos en la enseñanza, Barcelona, Gedisa. (1997)

CAMPIONE, Daniel. “Crisis y reforma del Estado en Argentina. Algunas observaciones sobre su desarrollo y resultados, en Investigaciones sobre Reforma del Estado, Municipios y Universidad". Gustavo Blutman (compilador). Buenos Aires. Facultad de Ciencias Económicas. 1999.

CARLI, Sandra "El estudiante universitario. Hacia una historia del presente de la educación pública" Editorial: Serie educación y sociedad (dirigida por Emilio Tenti Fanfani) 1ra. edición, Buenos Aires. Siglo XXI editores, 2012.

CARLI, Sandra, dir. y comp." Estudios sobre comunicación, educación y cultura, Una mirada a las transformaciones recientes de la Argentina"- Ed. Stella : La Crujía, 2003

CARNOY, M. y Moura Castro, C. de "¿Qué rumbo debe tomar el mejoramiento de la educación en América Latina?" Documento de antecedentes para el Banco Interamericano de Desarrollo, Seminario sobre Reforma Educativa, Buenos Aires. (1996),

CASASSUS Juan “Poder, lenguaje y calidad de la educación” En Boletín del Proyecto Principal, N 50. Abril 2000. Unesco, Santiago de Chile

CASTELLS, Manuel “Comunicacion Y Poder", Alianza Editorial, 2009. ISBN 9788420684994 Madrid 2009.

CASTELLS, Manuel “La ciudad informacional: tecnologías de la información, reestructuración económica y el proceso urbanoregional Alianza Editorial, Madrid, (1995)

CASTELLS, Manuel “La sociedad red”, Madrid, Alianza Editorial. (1996)

CASTELLS, Manuel La galaxia Internet. "Obertura: La red es el mensaje”; Plaza \& Janés Editores S.A; Barcelona. (2001)

CHARTIER, Roger “'Muerte o transfiguración del lector?", École des Hautes Études en Sciences (2000)

CLASSEN, Constance "Fundamentos de una antropologia de los sentidos" https://es.scribd. com/doc/115749789/Antropologia-de-Los-Sentidos-

CLAXTON, Guy "Anatomía de la intuición", en Atkinson, Terry y Guy Claxton (eds.), El profesor (2002)

COLE, Michael y Sylvia Scribner The Psichology of Literacy, Cambridge, Massachusetts, Harvard (1981) com/files/ma/do_weblogs_accelerate_expertise.pdf

COSTA, Joan La esquemática, Barcelona, Paidós. (1998)

CRAVINO, Luis María. Medir lo importante. Buenos Aires. Temas grupo Editorial. 2007

CRESPO, Karina (2005) “Imágenes que interpelan”, Educ.ar. Disponible en: http://weblog. educ.ar/educaciontics/archives/004814.php

CROVi Druetta, Delia (comp.). Bitácora de viaje. Investigación y formación de profesionales de la comunicación en América Latina. México. Instituto Latinoamericano de la Comunicación Educativa. 2005 
CZARNy, Marcela (2000) La escuela en Internet. Internet en la escuela. Propuestas didácticas para docentes no

DE ALBA, Alicia. Evaluación curricular. Conformación conceptual del campo. México. CESU-UNAM. 1992.

DE KERCKHOVE, Derrick Inteligencias en conexión, hacia una sociedad de la Web, Gedisa, España. (1999)

DE MAIRENA Juan (Antonio Machado leyendo en prosa) Citado por Martín Barbero, Jesús. http://www.cubadebate.cu/opinion/2009/11/10/todo-lo-que-sabemos-lo-sabemosentre-todos/

DEBORD, Guy “La sociedad del espectáculo” (La société du spectacle) 1967

DEl, Daniel. La tesis. Cómo orientarse en su elaboración. Buenos Aires. Prometeo Libros. 2006

DELFINO, Silvia (comp.). La mirada oblicua. Estudios culturales y democracia. Buenos Aires. La Marca. 1993

DI TELLA, Torcuato S (editor) Paz Gajardo, Susana Gamboa y Hugo Chumbita Diccionario de Ciencias Sociales Políticas, Ediciones Puntosur Buenos Aires. (1989).

DÍAS SOBRINHO, José. Paradigmas e políticas de avaliaçao da Educaçao Superior. Autonomia e Heteronomia, en Universidad e investigación científica. Convergencias y tensiones. Hebe Vessuri (comp.). Buenos Aires. CLACSO. 2006

DICCIONARIOS LE ROBERT es el nombre de una casa editorial francesa creada en 1951 por Paul Robert y especializada en la publicación de diccionarios de lengua francesa.

DICKINSON, Guy “Weblogs - can they accelerate expertise?". Disponible en: http://www. participo. (2003)

DOCUMENTO CURRICULAR, Diagnóstico y Plan de Estudios 1998. Ediciones de Periodismo y Comunicación. Facultad de Periodismo y Comunicación Social. UNLP. La Plata 1997

DUBOIS, Philippe El acto fotográfico. De la representación a la recepción, Barcelona-Buenos Aires México, (1986)

DUCATENZEILER Claudia, coordinadora de la Red Nacional Audiovisual Universitaria (Renau), http://informacionpresupuestaria.siu.edu.ar/DocumentosSPU/Cuadernillo-decadaganada.pdf

DUSSEL, Inés y Myriam Southwell “La escuela y la igualdad: renovar la apuesta”, El Monitor de la Ediciones Gestión 2000. (2004)

DUSSEl, Inés. Grupo de investigación "Políticas y reformas educativas". Papeles, Granada, Universidad de Granada, v.1, n.1, p.75-96, 2003

EFIMOVA, Lilia y Aldo De Moor "An argumentation analysis of weblog conversations", en Aakhus, (2004)

EFIMOVA, Lilia y Aldo De Moor "Beyond personal webpublishing: An exploratory study (2005) 
EGAN, Kieran (1999) La imaginación en la enseñanza y el aprendizaje para los años intermedios de la escuela,

ELISENDA ARDĖVOL, Marta Bertrán, CALLÉN Blanca, PÉREZ Carmen (2003) “Etnografía virtualizada: la observación participante y la entrevista

semiestructurada en línea" en Athenea Digital №3, primavera 2003. En http://bit.ly/QCFgKo

ESTALELLA, Adolfo "Anatomía de los blogs. La jerarquía de lo visible", revista Telos, Cuadernos de Investigación (2005)

ESTALELLA, Adolfo; Ardèvol, Elisenda "Ética de campo: hacia una ética situada para la investigación etnográfica de internet" en http://bit.ly/PZFRmN (2007)

FANELLI, Jorge. Hacer las ciencias sociales. Buenos Aires. Aula Abierta. 2002.

FELDMAN, Daniel "Imágenes en la historia de la enseñanza: La lámina escolar", Educ. Soc., Campinas, (2004)

FENSTERMACHER, Gary "Tres aspectos de la filosofía de la investigación sobre la enseñanza", (1989)

FERNÁNDEz, Ana M. (comp.). Instituciones estalladas. Buenos Aires. Eudeba. 1999.

FERREYRA, Pilar, "Más del $80 \%$ de los adolescentes y jóvenes usan mensajes de textos", Clarín, Argentina, 18

FERRY, JEAN-MARC; WOLTON, DOMINIQUE Y OTROS (1998). El nuevo espacio público. Gedisa. Barcelona.

FILMUS, Daniel "Breves Reflexiones sobre la escuela del futuro y presentación de la experiencia "Aulas en Red" Educación y nuevas tecnologías. Experiencias en América Latina IIPE-UNESCO, 2003

FOLLARI, Roberto Epistemología y Sociedad. Acerca del debate contemporáneo. Capítulo 5 "Proceso de objetivación y construcción social de la mirada"; Homosapiens Ediciones. (2000);

FORD, Aníbal Navegaciones. Comunicación, cultura y crisis. Buenos Aires, Amorrortu. (1994)

FORD, Aníbal Resto del mundo. Nuevas mediaciones de las agendas críticas internacionales, Buenos Aires, Norma. (2005)

FORD, Aníbal "Términos críticos de Sociología de la Cultura" en Carlos Altamirano (Director); Ediciones Paidos; Buenos Aires. (2002

FOUCAULt, Michel. Microfísica del Poder. Madrid. La Piqueta. 1992.

FREIRE Paulo, "Pedagogía de la Autonomía. Saberes necesarios para la práctca educativa". Editorial: Siglo XXI Editores Edición: 2008 Colección: Biblioteca Clasica

FRIGERIO, Graciela y Gabriela Diker (comps.) “La transmisión en las sociedades y en los sujetos, Un concepto de la Educación Acción" Ediciones Novedades Educativas Buenos Aires México (2004) 
FUENTES NAVARRO, Raúl "Comunicación, cultura y sociedad: fundamentos conceptuales de la postdisciplinariedad" Revista Trampas de la Comunicación y la Cultura. Año 1, N¹ Facultad de Periodismo y Comunicación Social. Universidad Nacional de La Plata. Mayo 2002

FUENTES NAVARRO, Raúl "La investigación de la comunicación en América Latina” Diálogos de la Comunicación. № 56, octubre de 1999. .

FUENTES NAVARRO, Raúl. “El campo académico de la comunicación en México como objeto de análisis auto-reflexivo", en Lozano, J.C. (ed.) La comunicación en México: (2005)

GAGLIANO, R. Educación, política y cultura adolescente (1955-1970). en: PUIGGRÓS, A. (comp.) Dictaduras y utopías en la historia reciente de la educación argentina (1955-1983). Buenos Aires: Galerna, 1997.

GARCIA CANCLINI, Néstor "Consumidores y Ciudadanos conflictos multiculturales de la globalización" Grijalbo 1995

GARCÍA CANCLINI, Néstor "El consumo sirve para pensar" en Revista Diálogos de la comunicación No 30, Lima: FELAFACS,

GARCÍA CANCLINI, Néstor "La globalización en pedazos: integración y rupturas en la comunicación", (1998) http://www.ciudadaniasx.org/la-globalizacion-en-pedazos.html

GARCÍA CANCLINI, Néstor Zonas de indecisión entre lo privado y lo público en Cultura y Comunicación: entre lo global y lo local. Ed. UNLP, La Plata. (1997)

GARCÍA CANCLINI, Néstor. "Cultura y Comunicación: entre lo Global y lo Local". Ediciones de Periodismo y Comunicación Nro.9. UNLP. Octubre 1997.

GARCÍA GUTIÉRREZ, Antonio. Otra memoria es posible: Estrategias descolonizadoras del archivo mundial. Buenos Aires. La Crujía. 2004

GARCIA Rolando "Ciencia e Ideología, Aportes polémicos", publicado por Ediciones de la Ciencia Nueva en Buenos Aires 1975, escribe el capítulo: “Ciencia, Política y concepción del Mundo. Gedisa, pp. 37-67.

GEERTZ, Clifford. Tras los hechos. Buenos Aires. Paidós. 1996

GETINO, Octavio "Las industrias culturales en el MERCOSUR: apuntes para un proyecto de políticas de Estado" en Industrias Culturales: mercado y políticas públicas en Argentina; Ciccus; Buenos Aires. (2003),

GEWERC BARUJEL, Adriana "El uso de weblogs en la docencia universitaria", Revista Latinoamericana. (2005)

GIACCAGLIA, Roberto Crítica creación, Córdoba, Argentina, Ediciones del Boulevard. (2006)

GIANELLA, Alicia. Introducción a la epistemología y a la metodología de la ciencia. La Plata. EDULP. 1999

GIDDENS, A. Ciencias Sociales y Globalización, en AA.VV., Desigualdad y globalización: cinco conferencias, Buenos Aires, Facultad de Ciencias Sociales - UBA y Manantial. (2001).

GIDDENS, Anthony y Jonathan Turner. La teoría social hoy. Buenos Aires. Alianza. 1995. 
GIMFERRER, Pere. "Rimbaud y nosotros", Ed: Publicaciones de la residencia de estudiantes, ISBN 84-95078-35-X

GIORDANO, Carlos Editor "Cuestiones sobre Epistemología, Teoría y Metodología del Campo de la Comunicación" Questions- Ediciones de Periodismo y Comunicación 1a ed. - La Plata: Universidad Nacional de La Plata. Facultad de Periodismo y Comunicación Social, 2011.

GIORDANO, Carlos Tesis de Doctorado: "23 Tesis sobre la Tesis. La comunicación para la transformación de la gestión educativa" Doctorado en Comunicación Facultad de Periodismo y Comunicación Social Universidad Nacional de La Plata Junio 2009

GIORDANO, Dora "El conocimiento. Un enfoque heurístico", en AA.VV., Cinco notas sobre heurística (2002) http://www.me.gov.ar/curriform/publica/tic.pdf

GOLLÁN, José Santos. Periodista del diario La Prensa en "Escuela Argentina de Periodismo". Imprenta de la Escuela Argentina de Periodismo. Círculo de Periodistas de la Provincia de Buenos Aires. Primera Serie N³. La Plata. 1943.

GÓMEZ BUENDÍA, H. Educación: La Agenda del Siglo XXI; PNUD-Tercer Mundo Editores, Colombia (1998),

GONZÁLEZ CASANOVA, Pablo. Las nuevas ciencias y las humanidades. De la Academia a la Política. Barcelona. Anthropos. 2005.

GRIMSON, Alejandro y Mirta Varela (2002) "Culturas populares, recepción y política. Genealogías de los estudios de comunicación y cultura en la Argentina", en Mato, Daniel (Coord.): Estudios y Otras Prácticas Intelectuales Latinoamericanas en Cultura y Poder. Caracas: CLACSO y CEAP, FACES, Universidad Central de Venezuela.

GRUFFAT, Carolina "Generación M: los chicos que crecieron con los nuevos medios" TIC en la escuela - Ministerio de Educación

GRUFFAT, Carolina "Nuevas tecnologías y nuevas prácticas, en números" [en línea], TIC en la escuela - Ministerio de Educación

HALL, Stuart "Estudios Culturales dos Paradigmas" en Causas y Azares No 1; Buenos Aires. (1994);

HALL, Stuart "Culture, the Media, and the Ideological Effect", en Curran, James et al., Mass Media(1997)

HARGREAVES, Andy "Teaching in the Knowledge Society", Nueva York, College Press. Haven and London, Yale University Press. (2003)

HERMES, J."Citizenship in the age of the Internet. European Journal of Communication", 21 (3), 295-309. (2006).

HINE, Christine "Virtual Ethnograpy" http://links.es/1962 2004)

HOBSBAWM, Eric "Historia del siglo XX", Buenos Aires, Crítica. CRÍTICA. GRIJALBO MONDADORI BUENOS AIRES. (1999)

HUERGO, Jorge y Fernández, María Belén. “Cultura escolar, cultura mediática / intersecciones". Bogotá. Universidad Pedagógica Nacional. 2000. 
IGLESIAS Dosil, María Noelia y TORRES, Mariana L Facebook, un espacio emergente. Interacción juvenil en la virtualidad. Buenos Aires. En http://www.redcomunicacion.org/ memorias/p_jornadas_p.php?id=1148\&idj=11 (2010). II Com. “Documento sobre doxas y epistemes de y en la Comunicación en el IICom" AA.VV Instituto de Investigaciones en Comunicación. FPCS UNLP Marzo 2014

IIPE - UNESCO. Gestión de la transformación educativa: requerimientos de aprendizaje para los comunicadores. IIPE - UNESCO Sede Regional Buenos Aires Argentina, 1999.

IIPE - UNESCO. La integración de las Tecnologías de la Información y la Comunicación en los Sistemas Educativos. Co publicado con el Ministerio de Educación, Ciencia y Tecnología/PROMSE Argentina, 2006.

JENKINS Henry, "Destripando Survivor. La anatomía de una comunidad de conocimientos" Convergence culture: where old and new media collide, nyu press, Nueva York 201'

JENKINS Henry, Convergence culture. La cultura de la convergencia de los medios de comunicación, Barcelona, Paidós, 2008.

JONASSEN, David Learning from, learning about and learning with computing: a rationale for mindtools. jsp?iCve=12213306. 1996

KAPLUN, Mario "El comunicador popular", cap. 1: Modelos de educación y modelos de comunicación. Ed. Lumen-Humanitas. Argentina. 1996

KLIKSBERG, Bernardo (2002) Hacia una economía con rostro humano, Buenos Aires, Fondo de Cultura Económica.

KNORR CETINA, Karin. La fabricación del conocimiento. Un ensayo sobre el carácter constructivista y contextual de la ciencia. Quilmes. Editorial UNQUI. 2005.

LATOUR, Bruno "Cogitamus. Seis cartas sobre las humanidades científicas" Paidós Espacios del Saber. Buenos Aires. Barcelona 2012.

LEWKOWICZ, Ignacio Pensar sin Estado. La subjetividad en la era de la fluidez, Buenos Aires, Paidós.92 (2004)

LIGUORI, Laura "Las nuevas tecnologías de la información y la comunicación en el marco de los viejos problemas y desafíos educativos Tecnología Educativa. Política, historias, propuestas. Edith Litwin (Compiladora) Litwin, Edith (2004)

MARCHESI A. y E. Martín Calidad de la enseñanza en tiempos de cambio; Ed. Alianza, Madrid. (1998)

MARINO, Santiago "Argentina: El Proceso de Regulación Democrática" en Proceso Progresismo y políticas de comunicación: manos a la obra / Gustavo Gómez Germano. [et. al.];edición literaria a cargo de Alberto Koschützke y Elisabet Gerber. - 1a. ed. - Buenos Aires: Fundación Friedrich Ebert, 2011.

MARTIN BARBERJO, Jesús "Todo lo que sabemos, lo sabemos entre todos" http://www.cubadebate.cu/opinion/2009/11/10/todo-lo-que-sabemos-lo-sabemos-entre-todos

MARTÍN BARBERO, Jesús De los medios a las Mediaciones, Comunicación, Cultura y Hegemonía, ediciones G.Gilli, Barcelona (1987) 
MARTÍN BARBERO, Jesús "Comunicación fin de siglo: ¿Para dónde va nuestra investigación?". En Telos N. ${ }^{\circ} 47$, Madrid. http://www.comunicacionymedios.com/Reflexion/teorias/ findesiglo.htm

MARTÍN BARBERO, Jesús "El cambio en la percepción de los jóvenes. Socialidades, tecnicidades y subjetividades" en Morduchowicz Roxana (coord.) Los jóvenes y las pantallas; Gedisa, Barcelona. http://www.infoamerica.org/documentos_pdf/martin_barbero1.pdf (2008);

MARTIN BARBERO, Jesús "Jóvenes: comunicación e identidad" Pensar Iberoamérica. Revista de Cultura OEI http://www.oei.es/pensariberoamerica/ric00a03.htm"

MARTÍN BARBERO, Jesús "Tecnicidades, identidades, alteridades: des-ubicaciones y opacidades de la comunicación en el nuevo siglo diálogos de la comunicación Departamento de Estudios Socioculturales. ITESO, Guadalajara, México (2002)

MARTIN BARBERO, Jesús La formación del campo de estudios de Comunicación en Colombia[*] http://res.uniandes.edu.co/view.php/98/view.php AGOSTO 1999

MARTÍN BARBERO, Jesús y Germán Rey "Oralidad cultural e imaginería popular", en Los ejercicios del ver. Hegemonia audiovisual y ficción televisivaGedisa. Barcelona ISBN: 847432-753-9 1999

MARTIN BARBERO, Jesús. "El Oficio del Comunicador" en publicación Renglones, n 48, abril-junio, 2001.

MARTÍN BARBERO, Jesús. "Procesos de comunicación y matrices de cultura” Itinerario para salir de la razón dualista. "De la transparencia de los discursos a la opacidad del mensaje" FELAFACS. Barcelona, 1988.

MARTÍN BARBERO, Jesús: "Pensar la sociedad desde la comunicación. Un lugar estratégico para el debate de la modernidad". Ponencia en el Seminario sobre Comunicación y Ciencias Sociales, FELAFACS. Bogotá. En: FUENTES NAVARRO (1991): “Un campo cargado de futuro. El estudio de la comunicación en América" Latina. Guadalajara: ITESO/Maestría en Comunicación, octubre de 1991.

MARTÍN-BARBERO, Jesús (2009). "La nueva experiencia urbana: trayectos y desconciertos", Ciudad Viva N¹, Junta de Andalucía, enero de 2009.

MARTÍN-BARBERO, Jesús A Latin American perspective on communication/cultural mediation. Global Media and Communication. (2006).

MARTINIC, S. Conflictos políticos e interacciones comunicativas en las reformas educativas en América Latina. Revista Iberoamericana de Educación, (27), 2001

MARX, K y Engels. Feuerbach:"Oposición entre las concepciones materialista e idealista"Primer Capítulo de La Ideología Alemana. https://pensaryhacer.files.wordpress.com/2008/06/ la-ideologia-alemana1.pdf

MASTRINI, Guillermo entrevista publicada en http://www.rnma.org.ar/radial/enredandolas-mananas/2176-enredando-las-mananas-programa-del-10-10-2014

MATA, María Cristina. “De la cultura masiva a la cultura mediática”. En Revista Diálogos de la comunicación, No 56, FELAFACS. Lima, Perú, 1999 
MATTELART, Armand “La mundialización de la comunicación", Barcelona, Paidós. 1998

MATTELART, Armand "Pasado y presente de la Sociedad de la información: entre el nuevo orden" Localización: Telos: Cuadernos de comunicación e innovación, ISSN 0213-084X, №. 67, 2006, págs. 13-26

MEAD Margaret, Cultura y compromiso, ps 105 y 106, Granica, Buenos Aires, 1971

MENDICOA, Gloria. Sobre Tesis y tesistas. Lecciones de enseñanza-aprendizaje. Buenos Aires. Espacio Editorial. 2003

MINZI, Viviana y Valeria Dotro “Los niños de hoy no son como los de antes", TIC en la escuela - Ministerio de Educación

MONEREO, Carles "Internet, un espacio idóneo para desarrollar las competencias básicas", en Monereo Carles (2005)

MORAGAS, Miquel. “La investigación y formación en comunicaciones” En la era de la globalización. CICOSUL. LIMA 1998. Pag 18 enunciado por

MORAGAS en ocasión del IX Encuentro Latinoamericano de Comunicación Social

MORALES, Susana. Brecha digital y educación en la Sociedad global de la Información, en Medios Informáticos en la educación a principios del siglo XXI. Roxana Cabello y Diego Levis (editores). Buenos Aires. Prometeo Libros. 2007

MORDUCHOWICZ, Roxana (2008) (coord.) Los jóvenes y las pantallas; Ed. Gedisa, Barcelona; 2008.

MORDUCHOWICZ, Roxana, La generación multimedia. Significados, consumos y prácticas culturales DE LOS JÓVENES. Editorial: Paidós.

MORIN, Edgar (1999) "Los siete saberes necesarios para la educación del futuro", París, Unesco. Disponible mundial de la información y la comunicación y la cumbre mundial sobre la Sociedad de la Información",mx/portal/infouv/boletines/tintero/tintero_10/articulos/cristobal.htm

MORíN, Edgar .¿La ciencia pierde la razón?: Revista Universidad del Valle, № 17, agosto. (1997),

NIELSEN, Jacob (2006) “Digital Divide: The Three Stages” [en línea], en Useit.com. Disponible en: http:// nl/dscgi/ds.py/Get/File-41656/lap2004_demoor_efimova.pdf

NUN, José “El otro reduccionismo", en América Latina: ideología y cultura, San José, Flacso, 1982, pág.40.

OLAF LOOMS, Peter "La revolución desconocida", Revista Red Digital 1. Disponible en: http:// (2002)

ONG, Walter Oralidad y escritura. Tecnologías de la palabra, Buenos Aires, Fondo de Cultura Económica. (1993)

OROZCO GÓMEZ Guillermo Paradigmas de producción de conocimientos en la investigación de la comunicación desde la perspectiva cualitativa. (1996). 
OROZCO GOMEZ, Guillermo La investigación de la comunicación dentro y fuera de América Latina. Ediciones de Periodismo y Comunicación. UNLP, 1997

OROZCO GÓMEZ, Guillermo Televisión y audiencias: un enfoque cualitativo. Madrid: Ediciones de la Torre/Universidad

OROZCO GÓMEZ, Guillermo, Recepción y mediaciones, Buenos Aires: Ed. Norma, 2002.

ORTIZ, Renato Mundialización y cultura, Buenos Aires, Alianza. (1993)

OXFORD ENGLISH DICTIONARY (Draft edición), March 2009, consultado el 26 October 2010, «Shortened INTERNETWORK n., perhaps influenced by similar words in -net»

PADILLA DE LA TORRE, María Rebeca y Flores Márquez, Dorismilda (2011) “El estudio de las prácticas políticas de los jóvenes en Internet"en Comunicación y Sociedad. Departamento de Estudios de la Comunicación Social Universidad de Guadalajara México

PADILLA DE LA TORRE, Rebeca. “Tecnologías mediáticas y la permanente reconfiguración del sensorium. Su estudio en el marco de las ciencias sociales". En R. Reguillo (Coord.), Territorios en reconfiguración. Perspectivas situadas en torno a la interdisciplinariedad. Cuadernos deldecs (pp.131-148). Tlaquepaque, Jalisco: Iteso. (2008).

PAJARES TOSCA, Susana Literatura digital. El paradigma hipertextual, Cáceres, Universidad de Extremadura. (2003)

PÉREZ TORNERO, José Manuel (comp.), Comunicación y educación en la sociedad de la información, Barcelona, Paidós.

PÉREZ TORNERO, José Manuel "Las escuelas y la enseñanza en la sociedad de la información", en De la escritura al hipermedia Barcelona : Paidós, 2002

PERKINS, David (2001) “La persona-más: una visión distribuida del pensamiento y el aprendizaje", en Perspective on Communication Modelling (LAP 2004), New Brunswick. Disponible en: https://doc.telin.

PICCINI, Mabel. De políticas y poéticas: el orden de la comunicación, en La imagen del tejedor: Lenguajes y políticas de la comunicación. Mabel Piccini Editora. Ediciones Gustavo Gilli. México. 1990

PISCITELLI, Alejandro “Internet. Imprenta del siglo XXI" Barcelona : Editorial Gedisa, 2005

PORTA, Paula Inés "Formulación de un modelo de un área de formación Audiovisual Universitaria. Estructura Académica. Gestión y Recursos Asociados. Diseño y Gestión de un centro de Producción Audiovisual Universitario". Tesis de Maestría tesis de la Maestría: "Comunicación e Industrias Audiovisuales en el Espacio Iberoamericano" en la Universidad Internacional de Andalucía, Sede lberoamericana "Santa María de La Rábida"España (marzo 1998).

PORTA, Paula Inés "Informe de Avance". Programa de Evaluación y Transformación Curricular Facultad de Periodismo y Comunicación Social Universidad Nacional de La Plata - Diciembre de 2011

PORTA, Paula Compiladora del E-Book "Cuestiones sobre perfiles y prácticas profesionales del comunicador social. Ediciones PyC - IICom- Grupo Editorial Q ISBN 978-950-34-0772-1 La Plata 2011 
PORTA, Paula; RACIOPPE, Bianca; ZAPATA, Natalia y POIRÉ; María Julia (2011) "Jóvenes y TICs. Nuevos modos de socialización en internet" en Carlos Giordano, María Silvina Souza y Verónica Vidarte Asorey (editores) Cuestiones de la sociedad de la información, sociedad de la comunicación y sociedad del conocimiento. Viejas y nuevas tecnologías; editorial: Questión - Ediciones de Periodismo y Comunicación, La Plata, Buenos Aires. ISBN: 978-95034-0792-9

PORTA Paula Inés; STEIMBERG, Silvia Edith y MALL, Lautaro “Tecnologías de la Información y la Comunicación" $1^{\circ}$ año Polimodal. Textos Escolares para Todos iniciativa de la Dirección General de Cultura y Educación de la Provincia de Buenos Aires. Tercer Premio - 2007

PRIETO CASTILLO, Daniel. La comunicación en la educación - Ed. CICCUS: La Crujía, 1999

PUIGGRÓS, Adriana. Qué pasó en la educación argentina: desde la conquista hasta el menemismo. Buenos Aires: Kapelusz, 1996

QUIROZ, María Teresa Aprendizaje y comunicación en el siglo XXI, Buenos Aires, Norma. (2003)

RANCIÉRE, Jacques. El maestro ignorante. Cinco lecciones sobre la emancipación intelectual. Buenos Aires. Libros del Zorzal. 2007.

REGUILLO, Rossana Emergencia de culturas juveniles. Estrategias del desencanto, Buenos Aires, Norma. (2000)

RHEINGOLD, Howard "Pedagogy Of Civic Participation - The Transformation Of Education And ric00a03.htm (2006)

RINCÓN, Omar Narrativas Mediáticas o cómo se cuenta la sociedad del entretenimiento. Gedisa Editorial mayo 2006

RODRÍGUEZ LLERA, José Luis (comp.). Educación y comunicación. Barcelona. Paidós Comunicación. 1988.

ROETHKE, Theodore. Waking (1953) Nueva York

ROLLAND, Denis. América Latina. Guía de las organizaciones internacionales y de sus publicaciones. México. Fondo de Cultura Económica. 1987.

ROSENBERG, Marc E-learning. Strategies for Delivering Knowledge in the Digital Age, Nueva York, (2001)

SAINTOUT Florencia "Los Jovenes en la Argentina Desde una epistemología de la esperanza" Editorial: Universidad Nacional de Quilmes I.S.B.N : 9789875582583 Publicación: $22 / 04 / 2013$

SAINTOUT, Florencia "Abrir la Comunicación. Tradición y movimiento en el campo académico" (editora) Ediciones de Periodismo y Comunicación Social. UNLP 2003

SAINTOUT, Florencia "Descubrir una Comunicación. En búsqueda de las huellas" en Espacios de Comunicación Esteinou Madrid, Javier (Compilador); Universidad Iberoamericana; México. (1998) 
SAINTOUT, Florencia “Jóvenes: El Futuro llegó hace rato. Comunicación y estudios culturales latinoamericanos. Editorial: EPC Educación. Ediciones de Periodismo y Comunicación. La Plata, Provincia de Buenos Aires, 2006

SAINTOUT, Florencia; “Los Estudios de Recepción en América Latina” Ediciones de Periodismo y Comunicación La Plata;1998

SALINAS FERNÁNDEZ, Dino “La planificación en la enseñanza: Técnica, sentido común o saber profesional", (1994)

SALOMON, Gavriel (comp.), Cogniciones distribuidas, Buenos Aires, Amorrortu.1992

SAMAJA, Juan; Epistemología y Metodología. Elementos para una teoría de la investigación científica; Eudeba; Buenos Aires.1993

SARLO, Beatriz Tiempo presente, Notas sobre el cambio de una cultura, Buenos Aires, Siglo XXI. 2002

SAUTU, Ruth. Todo es teoría. Objetivos y métodos de investigación. Buenos Aires. Lumiére. 2003

SCHMUCLER Héctor "Comunicación, cultura y desarrollo" (1997) Editorial Biblos; $1^{\mathrm{a}}$ ed., Buenos Aires.

SCHMUCLER, Héctor en "Estudios de Recepción en América Latina, del Desarrollo a la Recepción. Causas y Azares, N¹, Buenos Aires, Edición Independiente, pp. 5-24

SCHMUCLER, Héctor “Un Proyecto De Comunicación/Cultura” en Revista Comunicación y Cultura, Vol. 12, Ed. Galerna, México. (1984),

SCHMUCLER, Héctor. Memoria de la Comunicación Editorial Biblos; $1^{\text {a }}$ ed., Buenos Aires. (1997)

SEN, Amartya. Una mirada estratégica a los temas sociales clave: la pobreza, el mal y el delito, en Pensamiento Social Estratégico. Bernardo Kliksberg (comp.). Buenos Aires. Siglo XXI Editores. 2008

SEVERIN, Eugenio "Modelos Uno a Uno en América Latina y el Caribe Panorama y perspectivas. http://idbdocs.iadb.org/wsdocs/getdocument.aspx?docnum=35838865

SILVERSTONE, Roger, ¿Por qué estudiar los medios?, Buenos Aires-Madrid: Amorrortu Editores, 2004

SOKAL, Alan y Jean Bricmont. Imposturas intelectuales. Buenos Aires. Paidós. 1999

SOTOLONGO CODINA, Pedro Luis y Carlos Jesús Delgado Díaz "El nuevo saber en construcción y las nuevas tecnologías" (2006)

SUÁREZ GUERRERO, Cristóbal (2003) “Del aprendizaje en red a una red de aprendizaje".

TADEU DA SILVA, Tomaz “Educación, poscrítica, currículum y formación docente", en Birgin, Alejandra et al. (1998) 
TAUBER, Fernando. Comunicación en la planificación y gestión de las universidades públicas argentinas. El caso de la UNLP en el trienio junio 2004-mayo 2007. La Plata. Ediciones de Periodismo y Comunicación Nro.37. 2009.

TEDESCO, Juan Carlos Educar en la sociedad del conocimiento, Buenos Aires, Fondo de Cultura Económica. (2000)

TENTI FANFANI, Emilio “Culturas juveniles y cultura escolar", Buenos Aires, IIPE, (2000)

TENTI FANFANI, Emilio La condición docente, Buenos Aires, Siglo XXI. (2005)

TENTI FANFANI, Emilio. Nuevos temas en la agenda de política educativa IIPE - UNESCO Buenos Aires y Siglo XXI Editores Argentina, 2008.

TENTI FANFANI, Emilio: "La escuela en el círculo vicioso de la pobreza", en Cuesta abajo. Ed. Unicef- Losada. 1993.

THOMPSON, John "Los media y el desarrollo de las Sociedades Modernas" Una Teoría de los medios de comunicación. Paidós Comunicación. Teorías Barcelona 1998

TíSCAR, Lara, "Blogs para Educar. Usos de los blogs en una pedagogía constructivista", Telos, (2005)

TURPO GEBERA, Osvaldo Washington (2008) “La netnografía. un método de investigación en Internet", en Revista Educar № 42, pp. 81-93

URREIZITETA V., María Teresa “La sociología interpretativa: globalización y vida cotidiana”, Espacio (2004)

URRESTI, Marcelo URRESTI, Marcelo "Adolescentes, consumos culturales y usos de la ciudad". (En línea). Ponencia. Seminario Internacional "La escuela media hoy. Desafíos, debates, perspectivas", 5 al 8 de abril. Buenos Aires: Ministerio de Educación/OEl. (2005),

VARELA, Mirta "Medios de comunicación e Historia: apuntes para una historiografía en construcción".

VASILACHIS Irene Métodos cualitativos I: Los problemas teórico-epistemológicos. Centro Editor de América Latina, Buenos Aires. (1993).

VERÓN, Eliseo La Semiosis Social. Ed. Gedisa, Buenos Aires. (1987).

WALLERSTEIN, Immanuel (coord.) Abrir las ciencias sociales. México Siglo XXI 1996 pag $81 / 83$

WILLIAMS, Raymond “Marxismo y Literatura"; Península; Barcelona. (2da. Edición) 2000

WILLIAMS, Raymond "Palabras clave. Un vocabulario de la cultura y la sociedad"; Ediciones Nueva Visión; Buenos Aires. (2000);

WILLIAMS, RAYMOND “Tecnologías de la comunicación e instituciones sociales”; en Historia de la Comunicación. Vol.2. De la imprenta a nuestros días; Barcelona; Bosch Casa Editorial, S.A. (1992) 
WILLIAMS, Raymond, “Historia de la Comunicación”, volumen 2, Madrid: Bosch Comunicación, 1981.

WINKIN, Yves “La Nueva Comunicación”, Ed. Paidós, Barcelona. (1982)

WINOCUR, Rosalía "Internet en la vida cotidiana de los jóvenes", Revista Mexicana de Sociología 68, num. 3, Universidad Autónoma de México -Instituto de investigaciones Sociales, México.(2006)

WITTROCK, Merldin, "La investigación en la enseñanza”, Madrid-Barcelona, Paidós-M.E.C. 1985

WOLTON, Dominique "Internet, ¿y después?: una teoría de los nuevos medios de comunicación", Barcelona, (1999)

WOLTON, Dominique "Salvemos la comunicación. Aldea global y cultura. Una defensa de los ideales" (Gedisa, 2006) 